\title{
Sedimentary and petrologic analysis of the Mississippian Price Formation at Sherwood Lake, West Virginia
}

\author{
Laura Ruth Sheehan \\ West Virginia University
}

Follow this and additional works at: https://researchrepository.wvu.edu/etd

\section{Recommended Citation}

Sheehan, Laura Ruth, "Sedimentary and petrologic analysis of the Mississippian Price Formation at Sherwood Lake, West Virginia" (2002). Graduate Theses, Dissertations, and Problem Reports. 1535. https://researchrepository.wvu.edu/etd/1535

This Thesis is protected by copyright and/or related rights. It has been brought to you by the The Research Repository @ WVU with permission from the rights-holder(s). You are free to use this Thesis in any way that is permitted by the copyright and related rights legislation that applies to your use. For other uses you must obtain permission from the rights-holder(s) directly, unless additional rights are indicated by a Creative Commons license in the record and/ or on the work itself. This Thesis has been accepted for inclusion in WVU Graduate Theses, Dissertations, and Problem Reports collection by an authorized administrator of The Research Repository @ WVU. For more information, please contact researchrepository@mail.wvu.edu. 


\title{
SEDIMENTARY AND PETROLOGIC ANALYSIS OF THE MISSISSIPPIAN PRICE FORMATION \\ AT SHERWOOD LAKE, WEST VIRGINIA
}

\author{
Laura R. Sheehan \\ Thesis Submitted to \\ The College of Arts and Sciences \\ at West Virginia University \\ In partial fulfillment \\ of the requirements for the degree of \\ Master of Science \\ in \\ Geology \\ Committee members: \\ Dr. Richard Smosna, Ph.D. \\ Dr. Thomas Kammer, Ph.D. \\ Dr. Helen Lang, Ph.D. \\ Department of Geology and Geography \\ Morgantown, West Virginia \\ 2002
}

Keywords: Price Formation, Mississippian, Petrology, Sedimentology 


\section{ABSTRACT \\ SEDIMENTARY AND PETROLOGIC ANALYSIS OF THE MISSISSIPPIAN PRICE FORMATION AT SHERWOOD LAKE, WEST VIRGINIA \\ Laura R. Sheehan}

Depositional facies determinations of the upper member of the Price Formation were made based on detailed descriptions of the six outcrops exposed along Sherwood Lake Road, Greenbrier County, West Virginia. Units were placed into one of seven facies: fluvial, distributary channels, crevasse-splays, swamp, beach-bar, lagoon, and interdistributary bay. Sandstone units of the respective facies were then petrographically analyzed.

Petrographic analysis indicates that there are distinct differences in mineralogies among the facies, particularly in the type of lithic grains present within the sandstones. High percentages of schist and phyllite rock fragments within the upper-delta-plain facies indicate that the parent material for the Price in southern West Virginia was dominantly metamorphic. Percentages of rock fragments change sytematically down the regional slope; upper-delta-plain facies have high percentages of metamorphic rock fragments (schist and phyllite) and lower-delta-plain facies have abundant sedimentary rock fragments (shale). The change in rock fragments down the paleo slope can be attributed to 1) increased mechanical degradation of metamorphic rock fragments with greater distance from the source area and 2) the introduction of sedimentary rocks fragments that were locally derived from within the mud-rich beds, typically more common in the lower portions of the deltaic system. 


\section{ACKNOWLEDGMENTS}

Written endeavors such as this are rarely the work of one person. I wish to acknowledge the assistance that many of my colleagues and professors have given to me, and extend particular thanks to certain individuals. My advisor Dr. Richard Smosna was not only an invaluable source of information, ideas and critical comments, but he was also an enthusiastic supporter of this particular project. The time and energy which he put into this mission is much appreciated, and for all of this I owe him many thanks. Dr. Thomas Kammer generously gave his time to explain the stratigraphy and nomenclature of the Price in great detail, and also lended his guidance in field techniques and tactics. I would also like to thank Dr. Helen Lang for her time and insightful comments. Her help with the petrology portion of this project has been obliging.

Special gratitude must also be extended to Phillips Petroleum Company who kindly funded all costs for the preparation of thin sections, and to Dr. Smosna who was the bridging liaison for the financial contribution, an added bonus which was greatly appreciated by the author.

Finally, I would like to thank my family and friends who have supported me through this long and arduous journey. My parents have instilled me with independence and determination, and guided me with love and understanding. For this I owe them more than words can tell. My siblings and friends have been my staunchest supporters, and I only wish I can help them as much as they've helped me. 


\section{TABLE OF CONTENTS}

PAGE

$\begin{array}{lr}\text { ABSTRACT } & \text { ii } \\ \text { ACKNOWLEDGMENTS } & \text { ii } \\ \text { LIST OF FIGURES } & \text { vi } \\ & \\ \text { INTRODUCTION } & 1 \\ \quad \text { Geological Setting } & 1 \\ \text { Area of Study } & 1 \\ \quad \text { Purpose of Study } & 1 \\ \text { Methodology } & 13\end{array}$

DEPOSITIONAL ENVIRONMENTS 15

$\begin{array}{ll}\text { Delta Plain } & 15\end{array}$

$\begin{array}{ll}\text { Meandering Channel Facies } & 28\end{array}$

Distributary Channel Facies $\quad 38$

Crevasse-Splay Facies $\quad 42$

Interdistributary Swamp $\quad 45$

Interdistributary Bay Facies $\quad 47$

Delta Front $\quad 51$

Beach-Bar $\quad 53$

$\begin{array}{ll}\text { Lagoon } & 58\end{array}$

SEDIMENTARY PETROLOGY 64

Petrography $\quad 64$

Quartz $\quad 64$

Feldspars $\quad 69$

Lithic Fragments $\quad 69$

$\begin{array}{ll}\text { Micas } & 71\end{array}$

$\begin{array}{ll}\text { Iron Minerals } & 74\end{array}$

Heavy Minerals $\quad 76$

$\begin{array}{ll}\text { Calcite and Fossils } & 76\end{array}$

$\begin{array}{ll}\text { Matrix and Cement } & 77\end{array}$

$\begin{array}{ll}\text { Petrologic Interpretation } & 79\end{array}$

$\begin{array}{lr}\text { Meandering Channel Facies } & 80\end{array}$

Distributary Channel Facies $\quad 82$

$\begin{array}{ll}\text { Crevasse-Splay Facies } & 87\end{array}$

Beach-Bar Facies $\quad 87$

Lagoon Facies $\quad 91$

Interdistributary Bay Facies $\quad 91$

Summary of Petrologic Analysis $\quad 94$ 
$\begin{array}{lr}\text { CONCLUSIONS } & 103\end{array}$

$\begin{array}{ll}\text { REFERENCES } & 106\end{array}$

$\begin{array}{ll}\text { APPENDIX A } & 110\end{array}$

Measured Sections at Sherwood Lake

APPENDIX B

Point-Count Data 


\section{LIST OF FIGURES}

Figure 1

Isopach map of the Price Formation in West Virginia.

Figure 2

Stratigraphic cross section from Bluefield to Sidling Hill.

Figure 3

Chronostratigraphic chart for the Price Formation.

Figure 4

Location map of Greenbrier County

Figure 5

Location map of Sherwood Lake outcrops

12

Figure 6

Stratigraphic Symbols used in stratigraphic columns.

Figure 7

Outcrop 1 stratigraphic column

17

Figure 8

Outcrop 2 stratigraphic column

18

Figure 9

Outcrop 3 stratigraphic column

19

Figure 10A

Outcrop 4 stratigraphic column

Figure 10B

Continuation of outcrop 4 stratigraphic column.

Figure 10C

Continuation of outcrop 4 stratigraphic column.

Figure 11A

Outcrop 5 stratigraphic column

Figure 11B

Continuation of outcrop 5 stratigraphic column.

Figure 12

Outcrop 6 stratigraphic column

Figure 13

Composite stratigraphic column for all 6 outcrops

Figure 14

3-D model of depositional environments present at Sherwood Lake. 
Figure 15

Figure 16

Figure 17

Figure 18

Figure 19

Figure 20

Figure 21a.

Figure 21b.

Figure 22

Figure 23

Figure 24

Figure 25

Figure 26

Figure 27

Figure 28

Figure 29
Stratigraphic column typically found in lowerdelta-plain deposits.

Photographs of outcrop 6.

Photographs of large-scale cross-beds present in fluvial sandstones.

Photographs of fluvial sandstones displaying scour-and-fill structure.

Close-up photograph of scour-and-fill structure present at outcrop 6.

Typical fining-upward sequence of meandering stream deposits.

Lateral accretion cross-bedding in small fluvial channel bodies.

Model for fluvial deposition yielding multstory sandbodies.

Photographs of upper distributary channels present at outcrop 5.

Typical sequence present in distributary channel facies.

Photographs of large-scale trough crossbeds present in upper distributary channel facies.

Photographs of large-scale planar crossbeds present in the lower-distributary channel facies.

Photographs of the crevasse-splay faices

Examples of crevasse-splay deposits found at Sherwood Lake

Photographs of the coal deposits present at outcrop 5.

Photographs of the interdistributary bay facies. 
Figure 30

Figure 31

Figure 32

Figure 33

Figure 34

Figure 35

Figure 36

Figure 37

Figure 38

Figure 39

Figure 40

Figure 41

Figure 42

Figure 43

Figure 44

Figure 45
Typical stratigraphic column of bay-fill succession.

Photographs of Unit 24- Transgressive lag deposit.

Stratigraphic cross-section of Price Formation from Bluefield to Crystal Springs, PA.

Typical shoreline sequence.

Photographs of Unit 26- Shoreface deposits.

Photograph of Unit 27- foreshore deposits.

60

Photographs of lagoonal deposits

Stratigraphic column for the lagoonal facies

QFL diagram for all 57 thin-section samples

SPS diagram for all 57 thin-section samples

65

Petrographic photo plate: A. and B. Quartz-rich sample, C. and D. sublitharenite.

Petrographic photo plate: A. and B. Lithic-rich sample, C. Undulose quartz, D. Polycrystalline quartz.

Petrographic photo plate: A. Chert, B. Plagioclase feldspar, C. Microcline feldspar.

Petrographic photo plate: A. and B. Phyllite grain, $\mathrm{C}$. and D. abundant rock fragments with phyllite dominant.

Petrographic photo plate: A. and B. Schist rock fragment, $\mathrm{C}$. and $\mathrm{D}$. deformed muscovite grain.

Petrographic photo plate: A. abundant hematite, B. siderite, C. Gastropod and calcite crystals

D. matrix 
Figure 46

Figure 47

Figure 48

Figure 49

Figure 50

Figure 51

Figure 52

Figure 53

Figure 54

Figure 55

Figure 56

Figure 57

Figure 58

Figure 59

Figure 60

Figure 61

Figure 62

Figure 63
Petrographic photo plate: A. and B. Pseudomatrix.

QFL diagram for fluvial facies.

SPS diagram for fluvial facies.

81

QFL diagram for upper distributary channel facies.

SPS diagram for upper distributary channel facies.

QFL diagram for lower distributary channel facies.

SPS diagram for lower distributary channel facies.

QFL diagram for crevasse-splay facies

88

SPS diagram for crevasse-splay facies

88

QFL diagram for beach-bar facies

89

SPS diagram for beach-bar facies

89

QFL diagram for lagoon facies

92

SPS diagram for lagoon facies

92

QFL diagram for interdistributary bay facies.

SPS diagram for interdistributary bay facies.

SPS diagram for mean of all facies

96

Ratio of total metamorphic rock fragments relative to total quartz for all facies

Ratio of total shale rock fragments relative to total quartz for all facies 


\section{INTRODUCTION}

The Price Formation consists of interbedded shale, siltstone and sandstone and is exposed throughout much of West Virginia and southwest Virginia. Deposition of the Price Formation occurred in Late Devonian-Early Mississipian time as a clastic wedge produced during the final phase of the Acadian Orogeny (Ettensohn, 1985, Bjerstedt, 1986; Hohn, et al., 1997). The Price has much economic significance; for example the sandstone beds are major reservoirs for oil and natural gas throughout the central Appalachian basin. Also, it contains the geologically oldest commercially mined coal in North America (Kreisa and Bambach, 1973).

Few detailed studies of the Price have been undertaken. In a majority of these studies detailed facies descriptions have been overlooked, therefore providing an opportunity for more research. Although the Price Formation is often referred to as the Price Sandstone, the Price exhibits a wide range of lithologies: shale and coal in some areas, mudstone and siltstone in others, and sandstone and conglomerate in still other areas. The multitude of lithofacies within the Price provides an ideal opportunity to analyze the sedimentary environments and corresponding lithofacies of a deltaic system as well as the resultant petrology. A study such as this should prove to be beneficial not only economically by providing information on the properties of potential or existing oil and gas reservoirs, but it will also provide more scientific information on the stratigraphy and petrology of deltaic facies.

\section{Geological Setting}

The history of nomenclature of the Price Formation in West Virginia is rather complex, and many of the geological complications associated with the Price are related 
to stratigraphic nomenclature and previous misidentification (Kammer and Bjerstedt, 1986). Nonetheless, the Price Formation in general is an interval of siliclastic rocks that represent prodelta, delta-front, delta-platform (ie. a broad shelf), and delta-plain facies (Matchen, 1992; Matchen and Kammer, 1994). By present practice, the Price is the section of rock that encompasses all uppermost Devonian and Lower Mississippian clastics above either the Chemung Formation (also called the Greenland Gap Formation), or the Hampshire Formation, and below either the Greenbrier Limestone or the Maccrady Formation (Bjerstedt, 1986a; Bjerstedt and Kammer, 1988).

Until the work of Kammer and Bjerstedt (1986), what is now defined as the Price Formation in West Virginia was called the Pocono Group or Series after a unit with similar stratigraphic position in northeastern Pennsylvania. By definition, the Pocono Group of Pennsylvania is a nonmarine unit that marks the base of the Carboniferous. Rocks in West Virginia, on the other hand, comprise a wide variety of lithologies and depositional environments dissimilar to the Pocono in northeastern Pennsylvania. In addition, these rocks in West Virginia, are laterally continuous and genetically related to equivalent rocks in Virginia called the Price Formation (Kammer and Bjerstedt, 1986). Recognizing that the Pocono name had been applied chronostratigraphically rather than lithostratigraphically, Kammer and Bjerstedt (1986) proposed that the name Pocono be abandoned in favor of Price Formation for all rocks in West Virginia.

Ettensohn (1985) described the Pocono and equivalent units as the fourth and final tectophase (post-Catskill) of the Acadian orogeny. Boswell (1988) interpreted the nature of the Acadian clastic wedge as a series of coalesced deltas derived from a number of rivers, rather than a single fluvial source. Matchen (1992) used subsurface data to 
visualize the westward extension of the Price. He examined the position of the delta front, and identified several sequences of stacked turbidites throughout his study area. He interpreted the sequences to represent the westward prograding delta front during Price deposition. He also noted that the Borden Formation of Kentucky is not the true stratigraphic equivalent of the Price, but rather chronologically equivalent only to the upper Price.

Paleocurrents directions in the Pocono Formation were studied by Pelletier (1958). Using trends in the Pocono such as sand-shale ratio, diameter of quartz grains in conglomerates, and average thickness of cross-bed layers, Pelletier determined that during Pocono/Price deposition currents in the central Appalachians flowed across Maryland, West Virginia, and Virginia in a northwesterly direction. Also Pelletier (1958) studied the petrology of the Pocono determining that the sandstone is dominantly a lithic arenite with a matrix consisting of crushed rock fragments. The depositional environment was interpreted as being "fluviatile with the source area being sedimentary and low-grade metamorphic rocks."

Carter and Kammer (1990) provided the first documented age determination for the Price Formation in West Virginia. Their detailed study of brachiopod faunas indicates that the Price Formation is in fact uppermost Devonian and lowermost Mississippian in age, contrary to older literature which traditionally regarded the Price as wholly Mississippian, with the base of the Mississippian coinciding with the base of the Price. In general Carter and Kammer (1990) found that most of the brachiopods of the Price Formation occur as lag deposits in high-energy sandstones. The brachiopods are commonly associated with bivalves, gastropods, cephalopods, crinoids and bryozoans. 
Bjerstedt in his 1986 doctoral dissertation, as well as Kammer and Bjerstedt (1986) and Bjerstedt and Kammer (1988), examined a large number of outcrops from central Pennsylvania to southwestern Virginia and described the Price Formation in detail. They interpreted Price deposition to have occurred in two depocenters, one north and one south of a structural high, termed the West Virginia dome (Figure 1), and it comprised a wide variety of marine and nonmarine depositional facies. The dome was first recognized by Dally (1956) as an "island during 'Pocono' deposition," but he believed it was more of a topographic rather than a structural high. It was later called the Pocono Dome by Donaldson and Shumaker (1981) and the West Virginia Positive Area by Craig and Connor (1979), and the dome was identified as a structural entity rather than a topographic one. Figure 1 is an isopach map of the Price, showing its distribution and thickness. The area of zero Price is the feature Dally first recognized, what was later to be named the West Virginia dome by Kammer and Bjerstedt (1986).

At the time of Price deposition the dome was a major control on sediment distribution in the area. Bjerstedt and Kammer (1988) noted that there are several shale and siltstone horizons that represent times when the progradation of the Price delta was interrupted by transgression in each depocenter. These beds often contain fossil lags and phosphate nodules that have been reworked and rounded by wave action. These transgressions are marked by T1-T4 on Figure 2. The Price north of the dome was dominated by non-marine and transitional-marine strata including fluvial and shallowwater deltaic systems, whereas the southern basin was characterized by marinedominated, and deep-water deltaic systems. These regional transgression occurred as a 


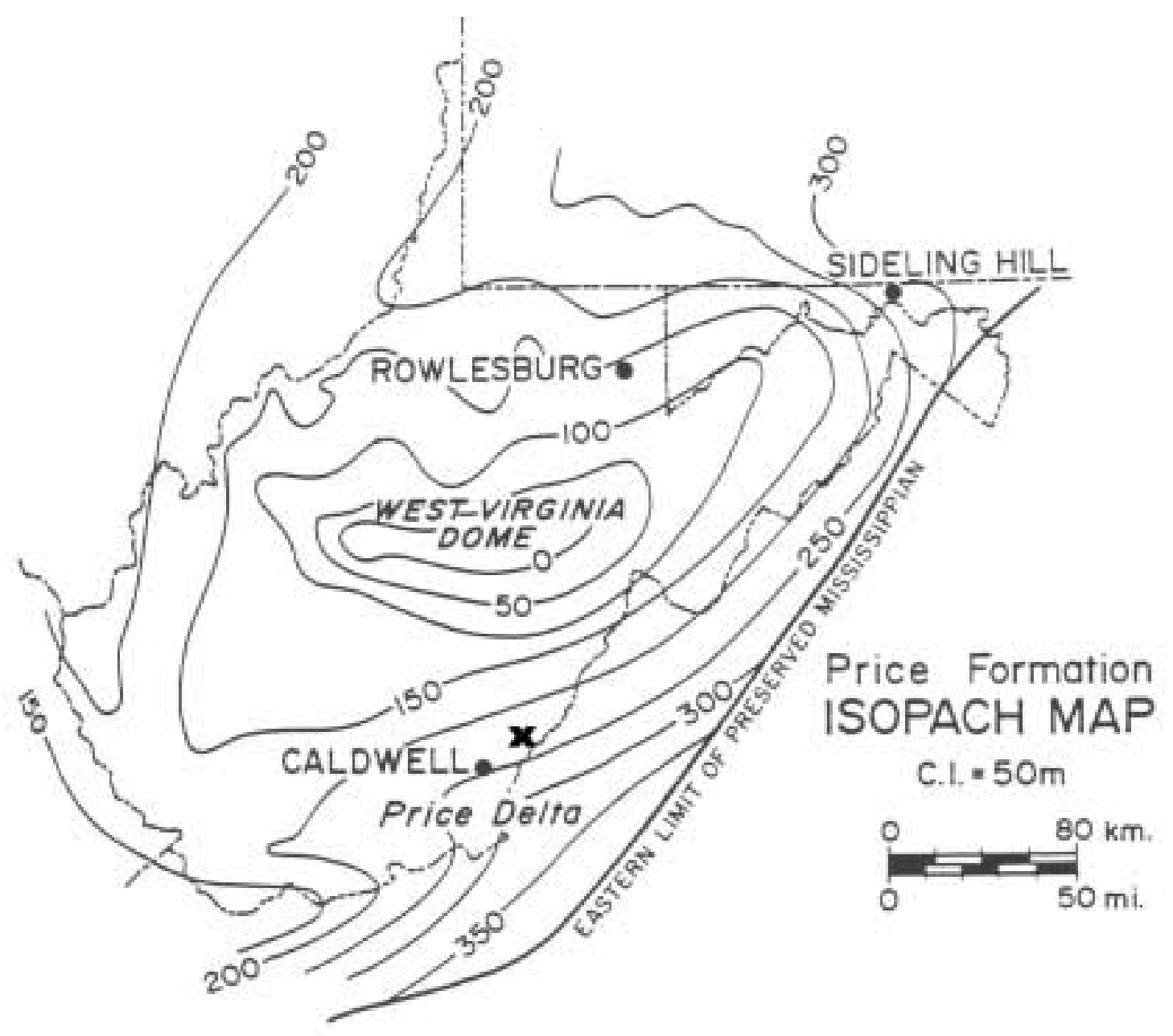

Figure 1. Isopach map of the Price in West Virginia. The area of zero Price represents the West Virginia Dome. The dots at Rowelsburg and Caldwell represent principal reference sections for the Price in their respective depocenters. The dot at Sideling Hill represents the principal reference section for the Rockwell Formation and the Purslane Sandstone. The X represents the location of the Sherwood Lake outcrops (Bjerstedt, 1986a; Dally, 1956). 


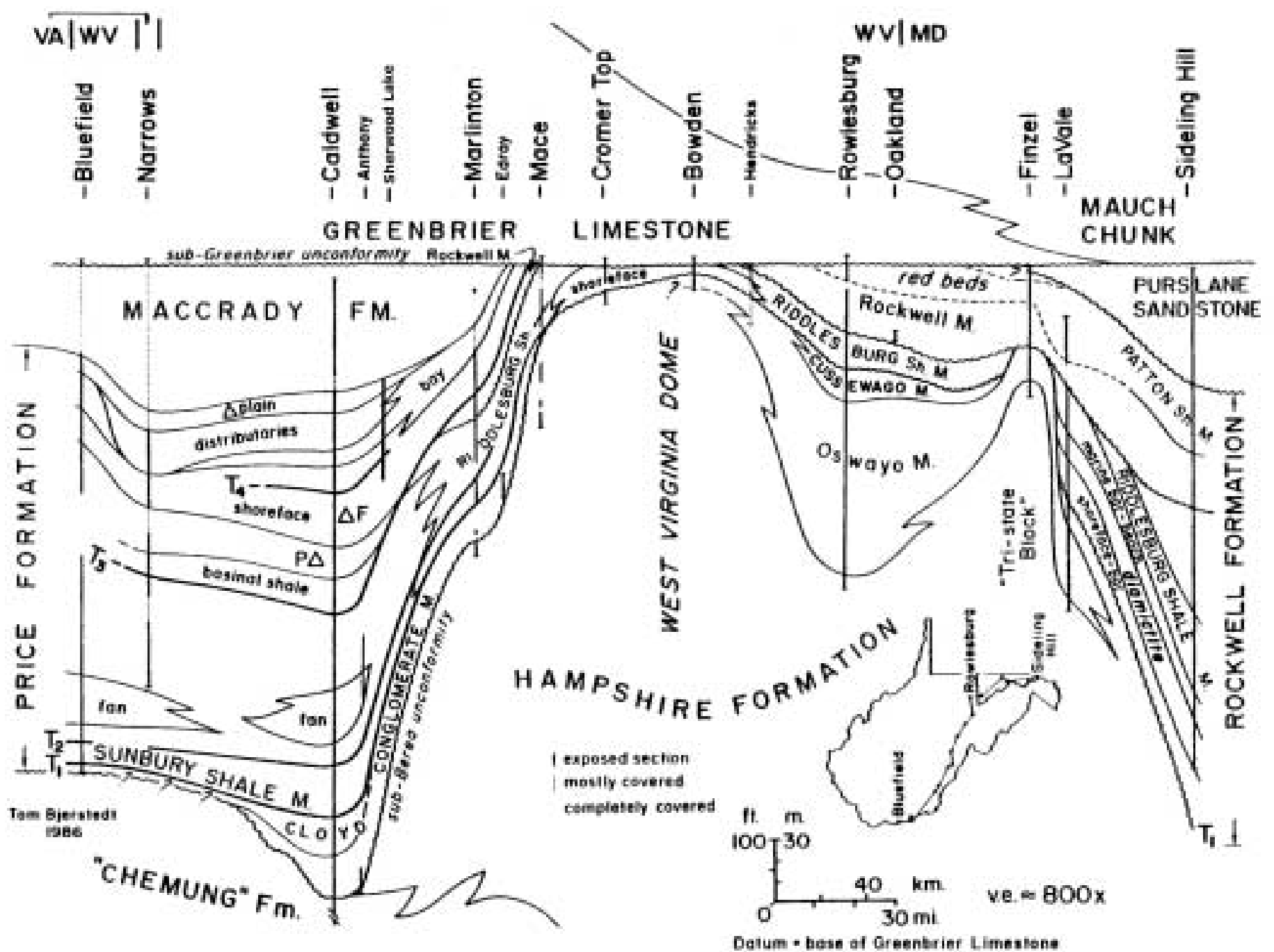

Figure 2: Stratigraphic cross-section from Bluefield to Sideling Hill using the base of the Greenbrier Limestone as datum (Bjerstedt, 1986). Stratigraphic position of outcrops at Sherwood Lake is indicated. 
result of the two depocenters subsiding rapidly, due to sediment loading or local tectonics (or the combination of the two), while concurrently the dome subsided very little (Bjerstedt, 1986a; Kammer and Bjerstedt, 1986; Matchen, 1992; and Mann, 1998).

In the southern depocenter, the Late Devonian Chemung Formation underlies the Price (Figure 2). Dennison (1970) proposed that Chemung of West Virginia be called the Greenland Gap Formation, so both names are found in the literature. Regardless, it consists of marine deposits that formed seaward of the prograding delta. These deposits are usually gray, brownish gray, green and red shale, siltstone, and sandstone (Fichter, 1986). According to Boswell (1985), several facies are represented in the Chemung including storm-amalgamated siltstones, proximal turbidites and shelf shales.

The Maccrady Formation conformably overlies the Price in the southern depocenter (Figure 2). In much of West Virginia it consists of nonmarine, alluvial-plain facies dominated by red mudstone and siltstone, but identification of the depositional environment is debatable (Bjerstedt, 1986). Dennison and Wheeler (1975) claimed an almost entirely marine environment for the Maccrady, but Bjerstedt (1986a) believes that only sections with evaporite beds (i.e. in Virginia) were indeed marine. Most Maccrady outcrops in West Virginia display thick, well-developed calcrete paleosols and are indicative of an alluvial-plain facies.

Kreisa and Bambach (1973) separated the Price Formation in southwestern Virginia into eight lithofacies but did not link environments of deposition to specific members. The lithofacies which they recognized are: bioturbated shale with marine fossils (marine shelf); interbedded sandstone with sole markings (prodelta slope); massivly bedded, well rounded, and sorted quartz-pebble conglomerate and interbedded 
quartz arenite (bar and barrier system); dominantly thin-bedded fine-grained sandstone and mudstone with marine fossils (barred bay); thin-to thick bedded, bimodally sorted, sandy conglomerate (mixed washovers); medium-grained, cross-bedded sandstone with fragmentary plant fossils (distributary channels); interbedded very fine sandstone and sandy shale with some bioturbation and plant fossils (delta plain); and finally coal and carbonaceous shale (swamp).

In contrast, Kammer and Bjerstedt (1986) cited that the rocks located south of the West Virginia dome are "indicative of an entire facies spectrum of a prograding, regressive, sedimentary wedge, from basinal to upper delta plain," Included in this sedimentary wedge are three members that are each considered to be equivalent to discrete genetic events. From oldest to youngest they are: the Cloyd Conglomerate Member, the Sunbury Shale Member, and an undifferentiated upper member, generally referred to as the upper Price member (Bjerstedt, 1986a; Kammer and Bjerstedt, 1986; Figure 3). Kammer and Bjerstedt (1986) designated the principal section for the Price in southern West Virginia as the exposure along the I-64 road cut near Caldwell in Greenbrier County. The Cloyd is described by Bjerstedt (1986) and Kammer and Bjerstedt (1986) as "a massive quartz pebble conglomerate, and a coarse conglomeratic sandstone with minor interbeds of shale." Its type section is located on Cloyds Mountain in Pulaski County, Virginia (Butts, 1940). Subsurface correlations and brachiopod identification indicate that the Cloyd Member is almost wholly Devonian in age (Bjerstedt and Kammer, 1988; Carter and Kammer, 1990). The Cloyd has been interpreted as being deposited during a rapid regression followed by a transgression. The 


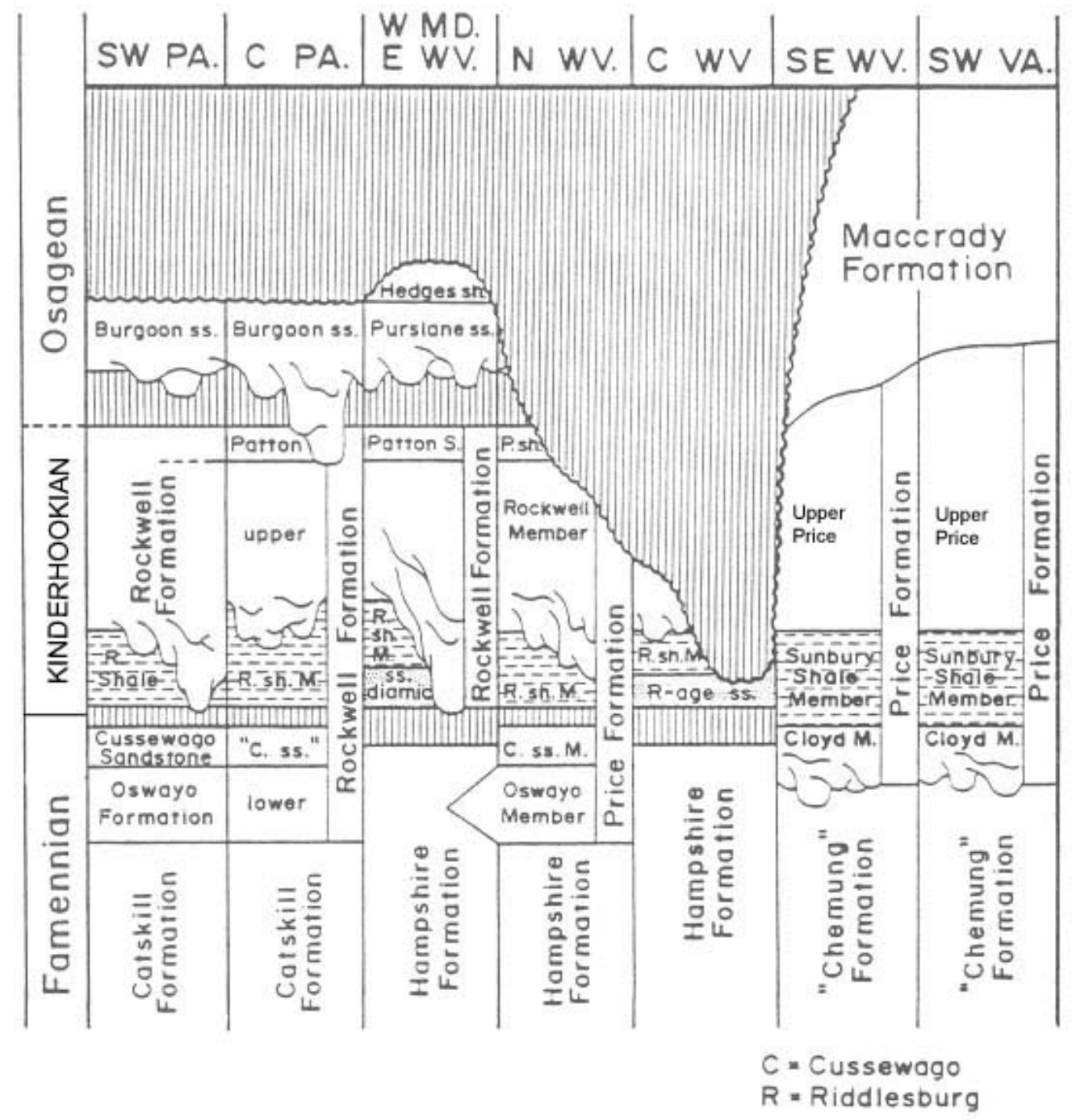

Figure 3: Chronostratigraphic chart for the Price Formation and correlatives in adjacent states (Bjerstedt, 1986a). 
myriad quartz pebbles present in the Cloyd are a result of the concurrent uplift and erosion of the ancestral Blue Ridge Mountains due to regional tectonics (Ettensohn, 1985; Bjerstedt and Kammer, 1988). Facies analysis as completed by Bjerstedt and Kammer (1988) implies that the Cloyd represents a dominantly fluvial system in the lower section that became more of a marine environment, such as a tidal flat or an estuary, in the upper section. Cloyd equivalents in the northern depositional system are part of the upper most Hampshire Group red beds and the Oswayo Member (Bjerstedt and Kammer, 1988).

The Sunbury Shale Member represents a second transgression within the Price Formation in the southern depocenter in earliest Mississippian time (Bjerstedt, 1986a, and Bjerstedt and Kammer, 1988; Figure 2). Ross and Ross (1985) contended that this may represent a major eustatic rise in sea level. The type section for the Sunbury is located in Sunbury, Ohio, where it is an organic-rich black shale (Hicks, 1878; as cited by Kammer and Bjerstedt, 1986). At Caldwell, however, it is a medium-gray silty shale with a few interbedded fine-grain sandstone turbidites (Bjerstedt, 1986a; Kammer and Bjerstedt, 1986). Arguments have been made in the past as to the depositional environment for the Sunbury Member in West Virginia, but most recent studies accept an offshore/deep-water origin (Bjerstedt and Kammer, 1988).

The unnamed upper Price member (subject of the present study) comprises the majority of the Price Formation in southern West Virginia (Figure 2). In general, the upper Price has a deltaic nature, but a wide range of environments are preserved. The heterolithic nature of the upper Price does not allow for it to be further subdivided into members that can be consistently recognized in outcrop. The upper Price usually consists 
of fine-to-medium-grain sandstone, siltstone, and silty shale (Bjerstedt, 1986; Bjerstedt and Kammer, 1988).

\section{Area of Study}

The study area consists of six outcrops exposed along Sherwood Lake Road in eastern Greenbrier County, West Virginia (Figures 4 and 5). As seen in Figure 5, the outcrops are on the northeast side of West Virginia County Road 14-1, located in the Monongahela National Forest. These six exposures represent about 60 meters of the upper Price. The first outcrop is located about 0.9 miles northeast of Rucker Gap Road. The next five outcrops continue eastward on County Road 14-1, where the last outcrop is exposed about 1.8 miles northeast of Rucker Gap Road. Outcrops 1-3 expose essentially the same stratigraphic section, and together outcrops 1-3 and 4, 5, and 6 make up an almost continuous section of the upper Price Member.

\section{Purpose of Study}

There is a great deal of information concerning the distribution and facies analysis of the Price Formation in West Virginia on a regional basis, but very few studies focus on the facies relationships within a single outcrop. Previous studies have generally focused on the subdivisions and correlations of the Price, general facies descriptions and depositional interpretation, biostratigraphy, and paleoecology. Aside from Mann's (1998) unpublished master's thesis, no petrographic work has attempted to correlate mineral studies with outcrop facies determination. The primary objective of this thesis is to provide a detailed facies analysis of a small area of the Price Deltaic Complex preserved in the Sherwood Lake outcrops. In addition, sandstones of these outcrops will 


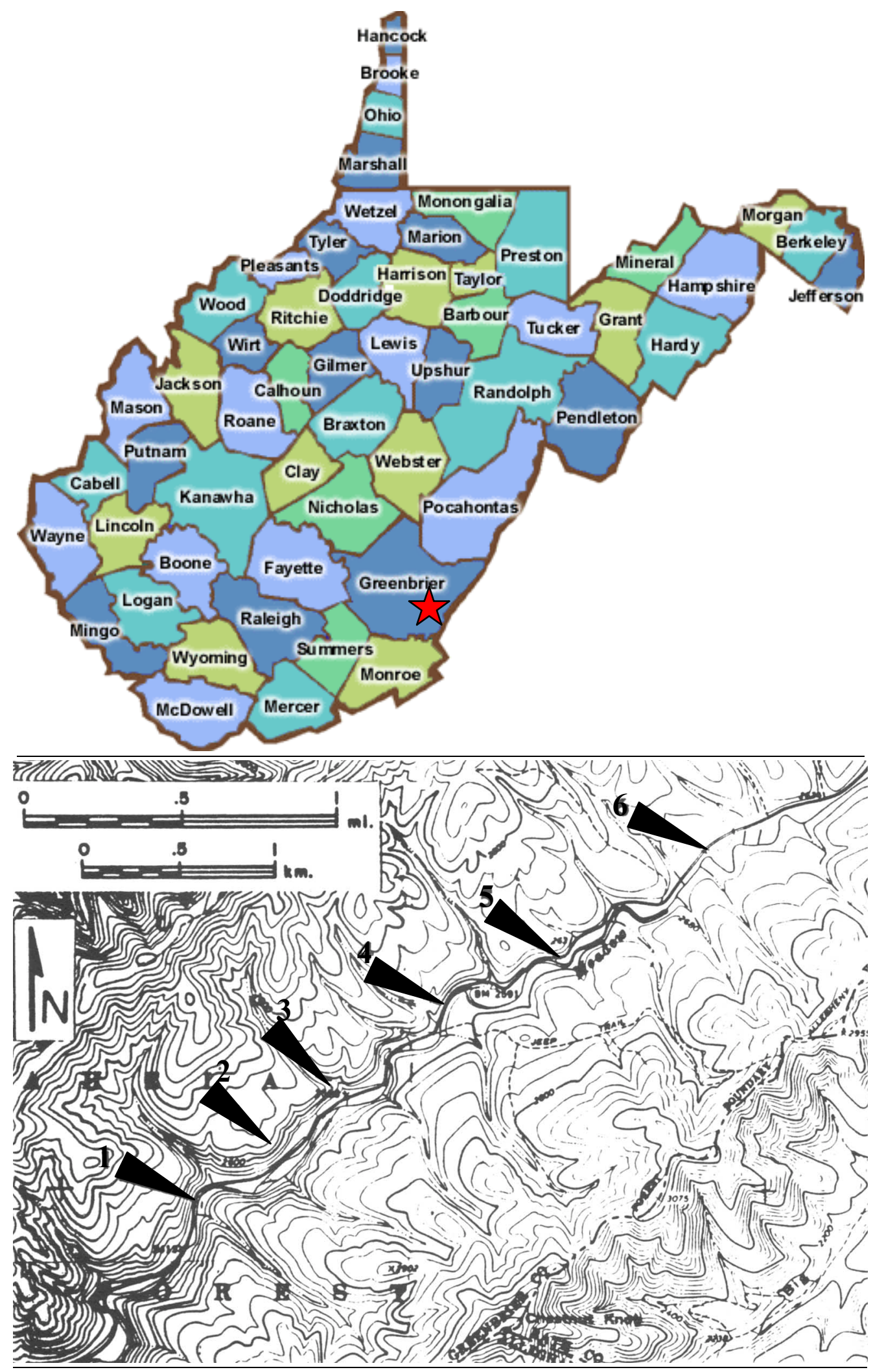

Figures 4 \& 5: County map of West Virginia, star shows approximate location of Sherwood Lake outcrops in Greenbrier County (top). Detailed topographic map of study area and outcrop locations (bottom) ( from Bjerstedt, 1986a). 
facies determinations made in the field can be further substantiated by petrographic methods. The intentions of this present thesis is to apply some of the similar methods Mann (1998) used to gain knowledge of the Price in southern West Virginia, specifically the Sherwood Lake outcrops. A more detailed analysis such as this will add to the understanding of the sedimentology and depositional environments of the Price delta.

\section{Methodology}

To begin the study, detailed stratigraphic columns were constructed to identify small-scale changes within the upper Price formation in southern West Virginia. Measuring began at the lowest exposed rock at each outcrop, and finished either when measuring could no longer be done due to inaccessibility or when the outcrop was obscured due to vegetation and cover. The outcrops were divided into units based on differences in lithology, sedimentary structures, and bedding characteristics. Within each stratigraphic unit, sedimentary textures and structures such as grain size, sorting, maturity, bedding thickness, and types of crossbedding were measured and described in detail. The data are presented in Appendix A. Detailed stratigraphic columns of the Sherwood Lake outcrops will aid in a better understanding of deposition during early Mississippian time. Facies interpretations were made based on descriptions and columns constructed by both myself and Bjerstedt (1986). Bjerstedt (1986) constructed a stratigraphic column in which 13 units were present. These units can be compared to the 39 units described by myself, with the difference being only in the amount of detail being presented. Because the purpose of this study was to go into greater detail about the facies present at Sherwood Lake than previous research had, hence smaller unit subdivisions 
and more detailed descriptions of each unit were made. Seven facies are present in the outcrops: fluvial, distributary channel, crevasse-splay, swamp, lagoon, beach-bar and interdistributary bay.

The second major goal of this project was to assess the sedimentary petrology of the sandstone units of all the facies. Most of the sandstone beds present were sampled and then made into thin sections for analysis. Normally the number of samples per unit is dependant upon the thickness of the unit, meaning that a thick unit will yield more samples than a thin unit. In instances such as this, samples were taken every 3-5 meters based on the thickness of the individual unit. On occasion a thin unit was measure multiple times because the unit showed visible changes from the base to the top, indicative of a petrologic change. A total of 60 samples were made into thin sections for further analysis.

Each of the 60 thin sections was described in detail. Microscopic descriptions included grain size, roundness, sorting, as well as a description of framework grains, accessory minerals, matrix, cement, and diagenetic minerals. 300 points per slide were counted using a grid system so that the entire slide would be equally represented. The data can be found in Appendix B.

Once the counts were made and the percentages of each mineral calculated, the samples were grouped by facies and plotted on ternary diagrams. The ternary diagrams were used in order to show similar mineralogies and groupings within sandstones of the same facies. 


\section{DEPOSITIONAL ENVIRONMENTS}

In southern West Virginia, deposition of the upper Price Formation occurred as a fluvial-deltaic system that prograded into a deep, oxygen-deficient basin. Delta progradation was interrupted by several transgressions, resulting in a deltaic sequence that preserves a wide spectrum of lithologies and environments. The upper Price can be related to the classic fluvially-dominated deltaic model in which a shallowing-upward sequence of environments, from offshore facies to coaly delta-plain facies, are preserved (Bjerstedt, 1986).

A total of 64 meters of the upper member of the Price Formation are exposed at the Sherwood Lake outcrops (Figures 6-12 and Appendix A). Outcrops 1, 2, and 3, however, expose the same section, thus making the total stratigraphic section 53 meters (Figure 13). By combining the work done by Bjerstedt (1986) on the Sherwood Lake outcrops and by the measured section and thin section analysis of this study, seven facies have been identified and interpreted. These facies contain sedimentary structures and lithologies indicative of both upper and lower delta-plain environments of a prograding delta (Figure 14).

\section{Delta Plain}

The delta plain is essentially the subaerial zone of a delta that is dominated by rivers. This domination causes difficulty when trying to distinguish between wholly fluvial systems and distributary channels within the delta, as the processes within the two environments are nearly identical (Reading and Collinson, 1996). Nonetheless, the delta plain tends to be an extensive lowland in which active, as well as abandoned, distributary channels are present. Associated with these distributary channels is the area between the 


\title{
Stratigraphic Symbols
}

\author{
Scour with pebbles
}

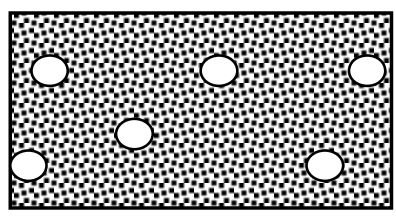

Conglomerate

טחนn Scour
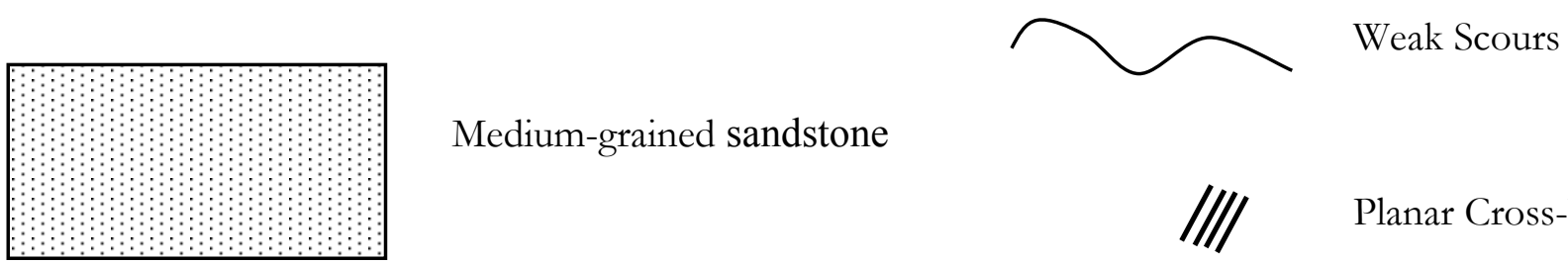

Medium-grained sandstone

/l/] Planar Cross-Bedding

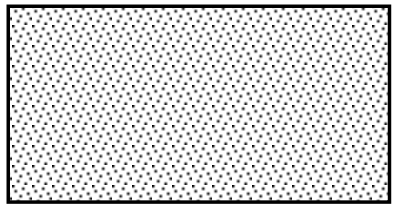

Fine-grained sandstone
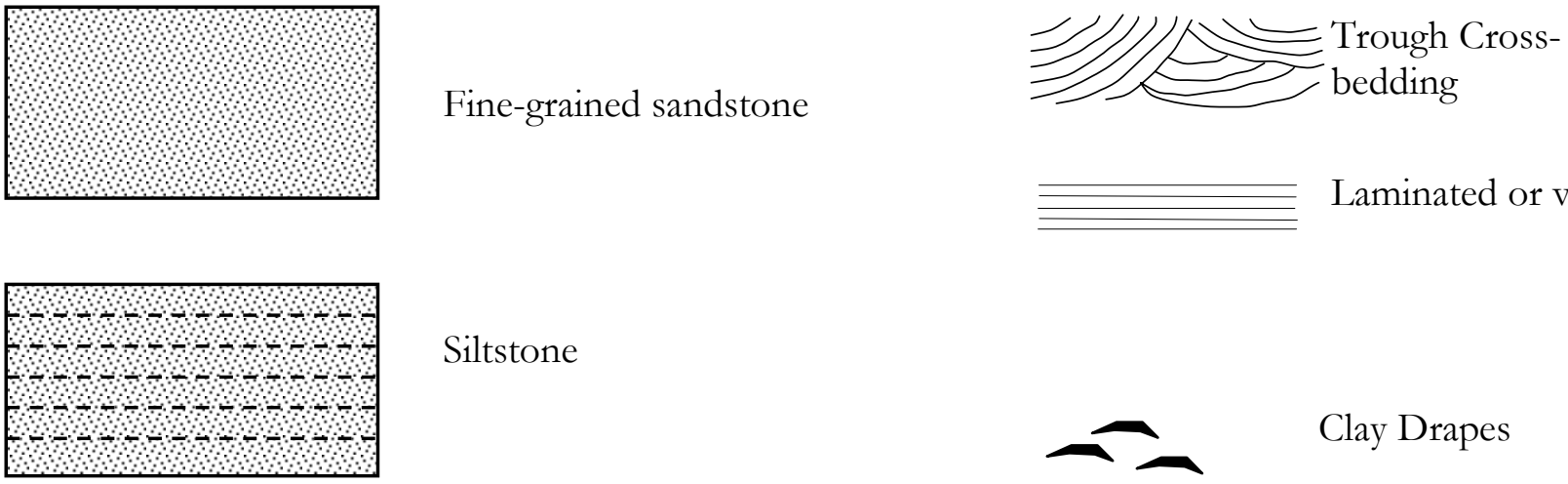

Siltstone

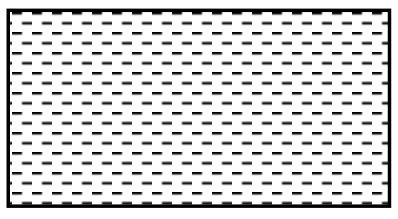

Mudstone
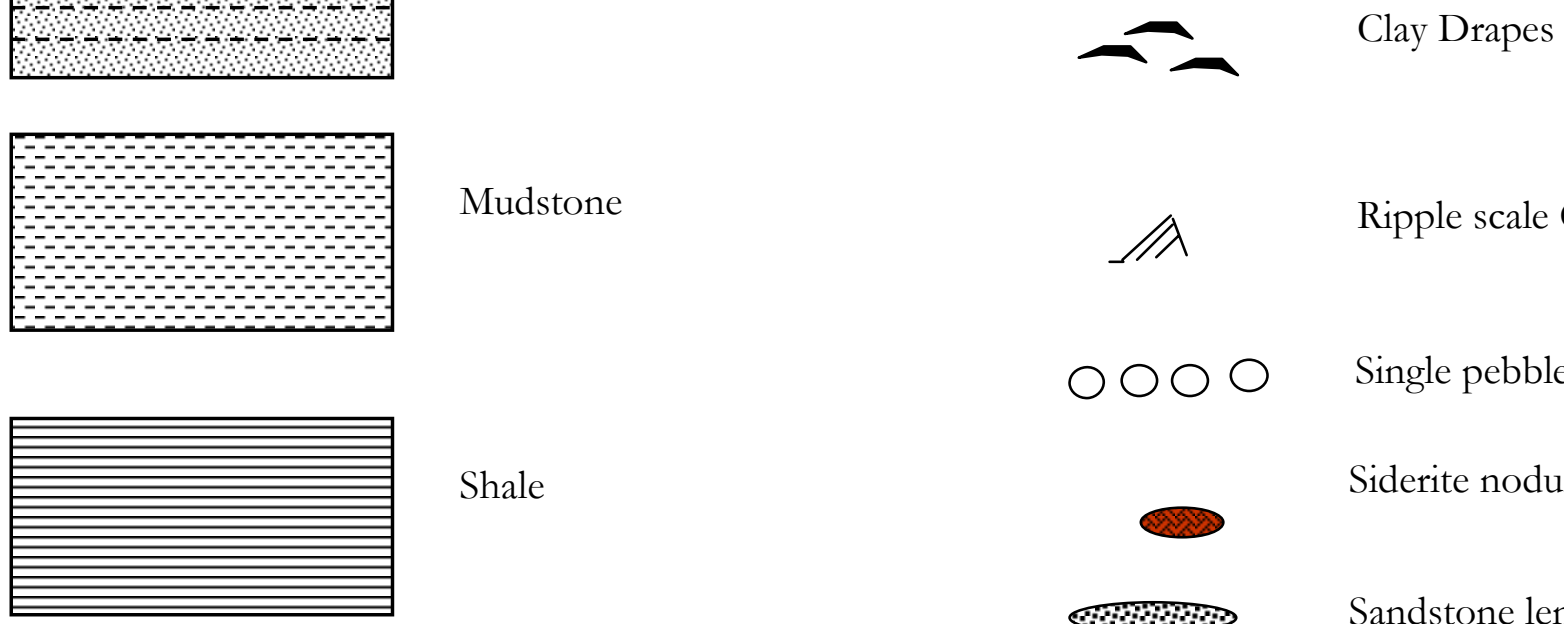

Shale

A Ripple scale Cross-bedding

$\bigcirc \bigcirc \bigcirc \quad$ Single pebble layer

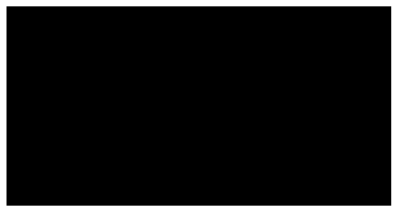

$\begin{array}{ll}\text { Shale } & \text { Single pebble layer } \\ \text { Coal } & \text { Siderite nodules } \\ & \text { Fossil material } \\ & \text { Coal Clasts }\end{array}$

Figure 6: Stratigraphic symbols used in stratigrtaphic columns. 


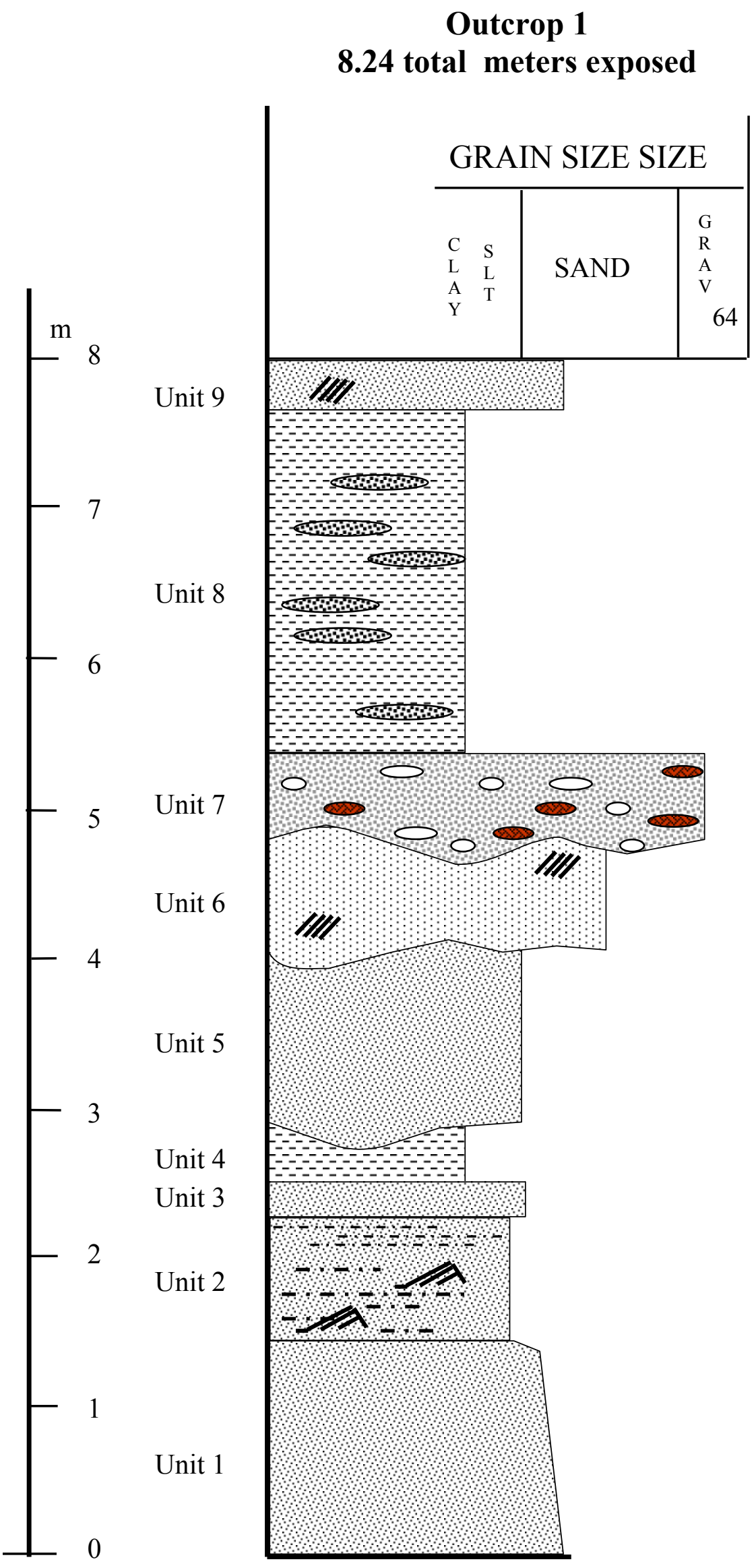

Figure 7: Outcrop 1 stratigraphic column 


\section{Outcrop 2 \\ 10.36 total meters exposed}

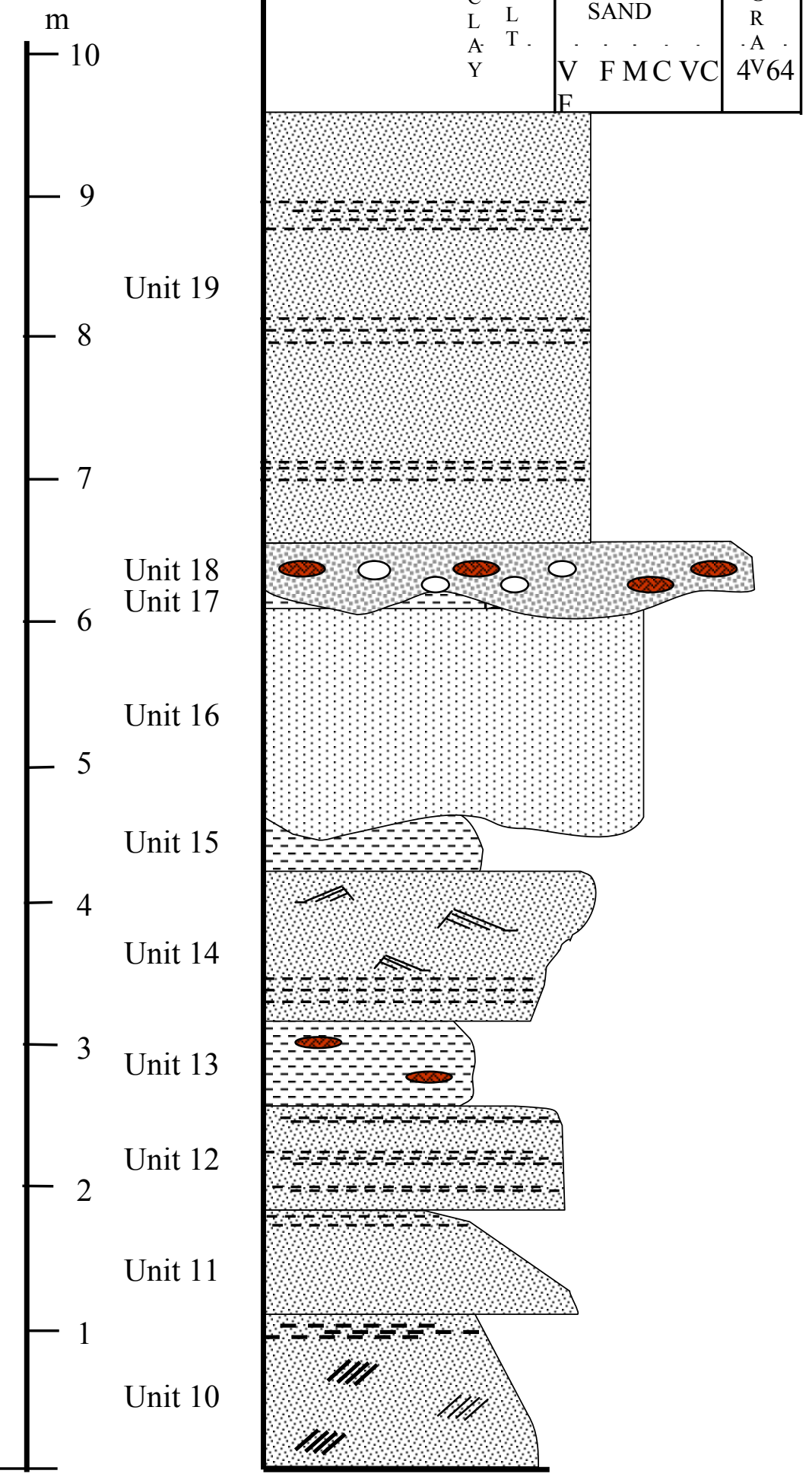

Figure 8: Stratigraphic column of outcrop 2. 


\section{Outcrop 3 \\ 2.78 total meters exposed}

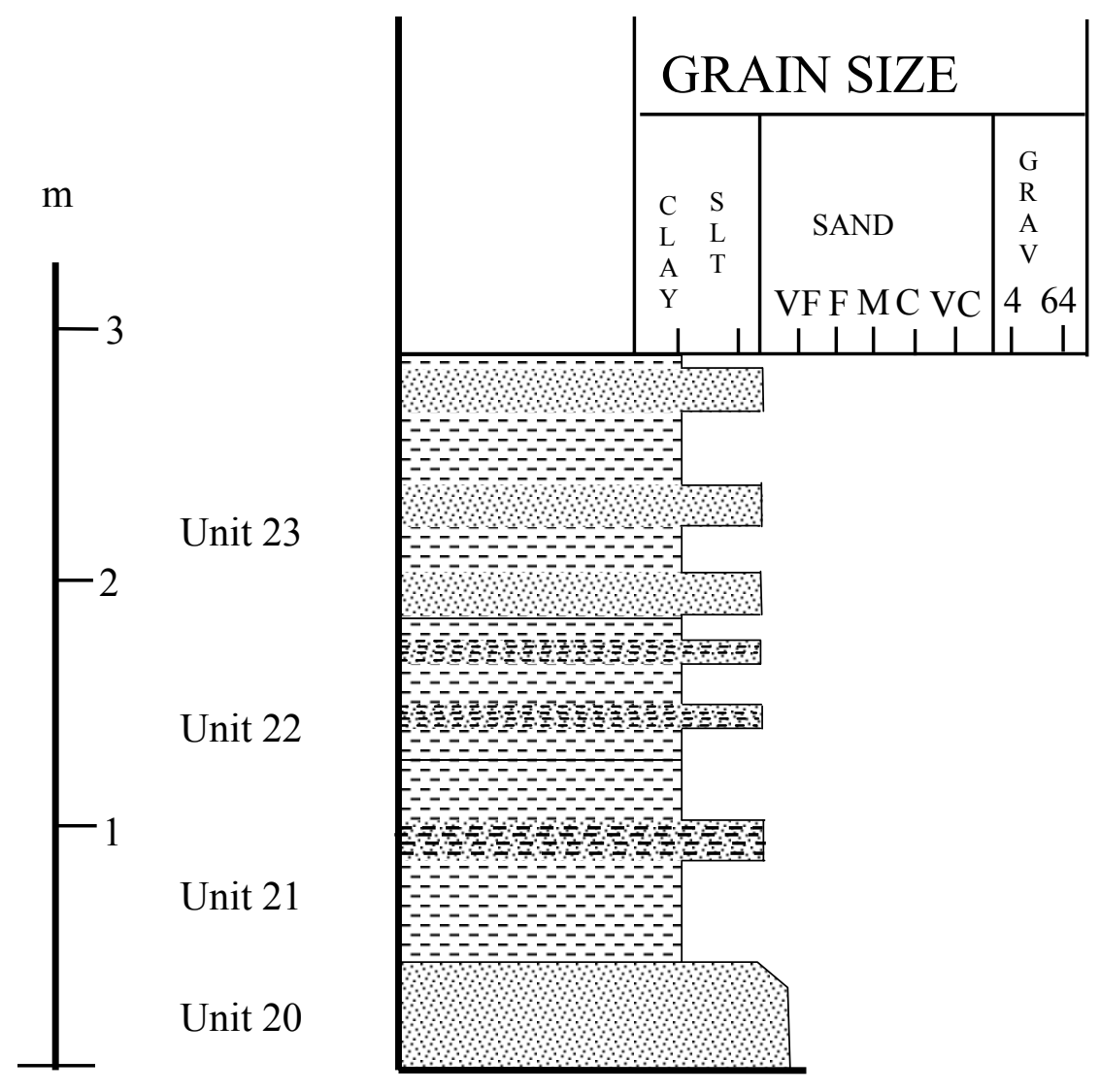

Figure 9: Outcrop 3 stratigraphic column. 


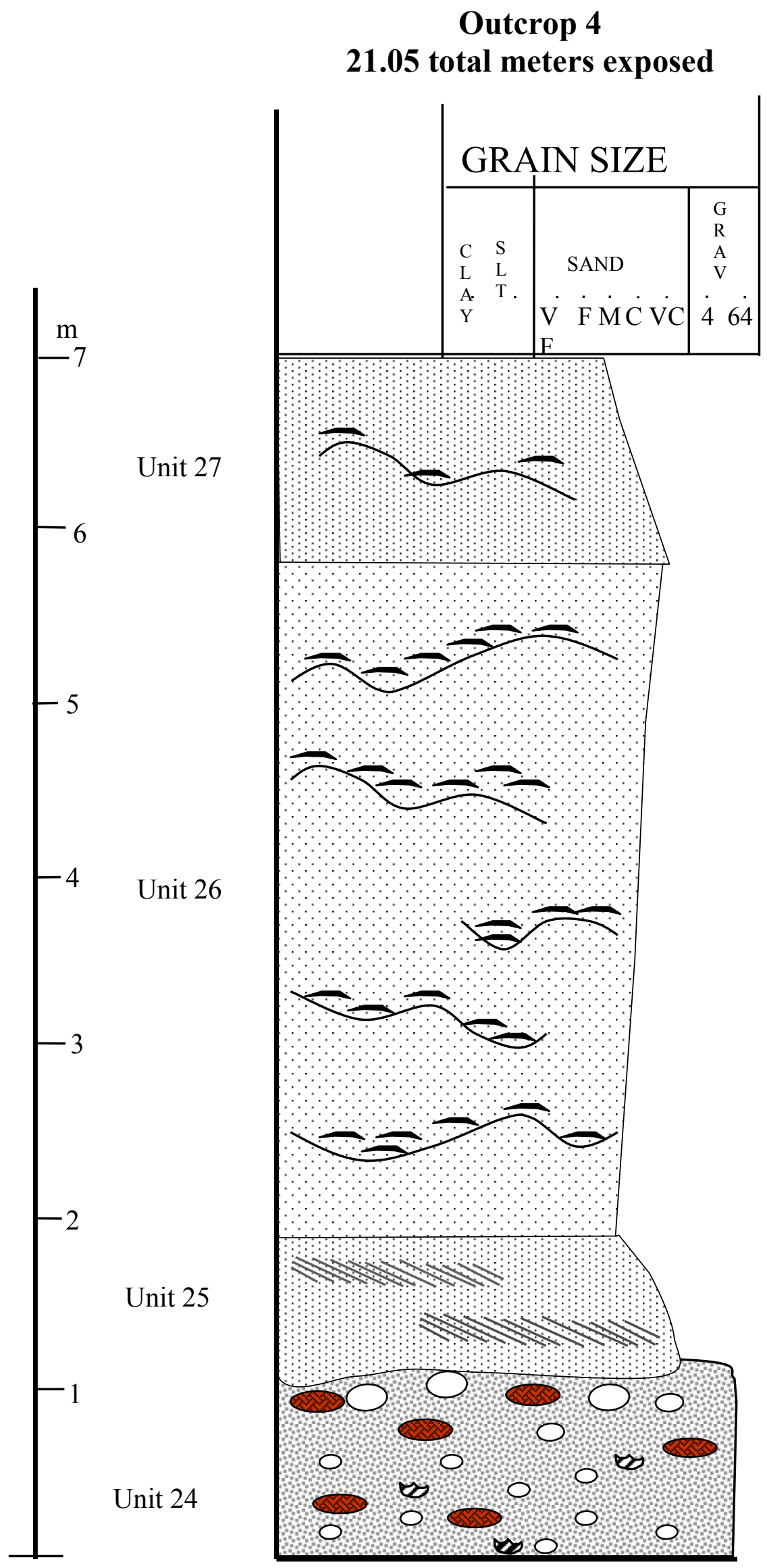

Figure 10A: Stratigraphic column of outcrop 4. 


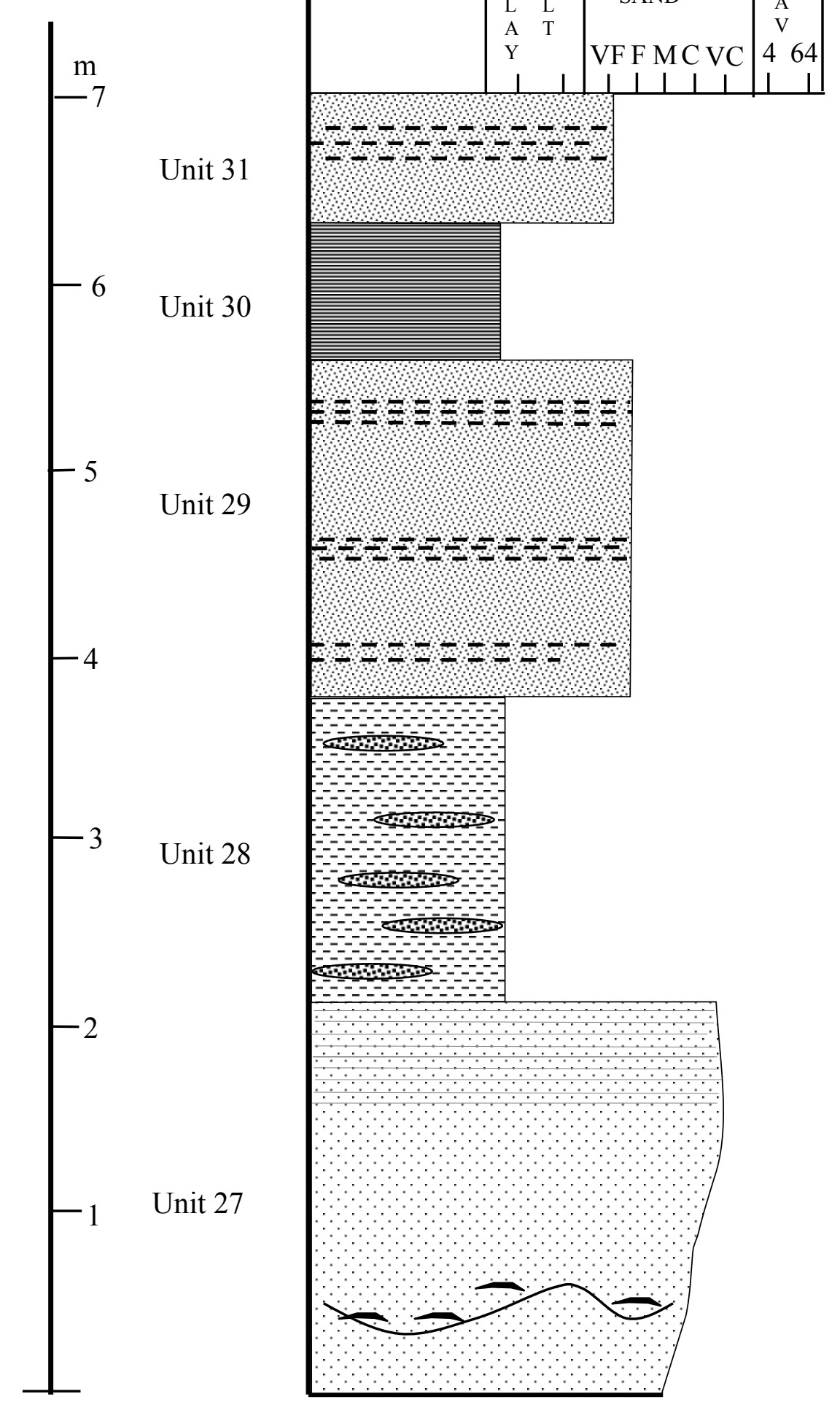

Figure 10B: Continuation of outcrop 4 stratigraphic column. 


\section{Outcrop 4 \\ 21.05 total meters exposed}
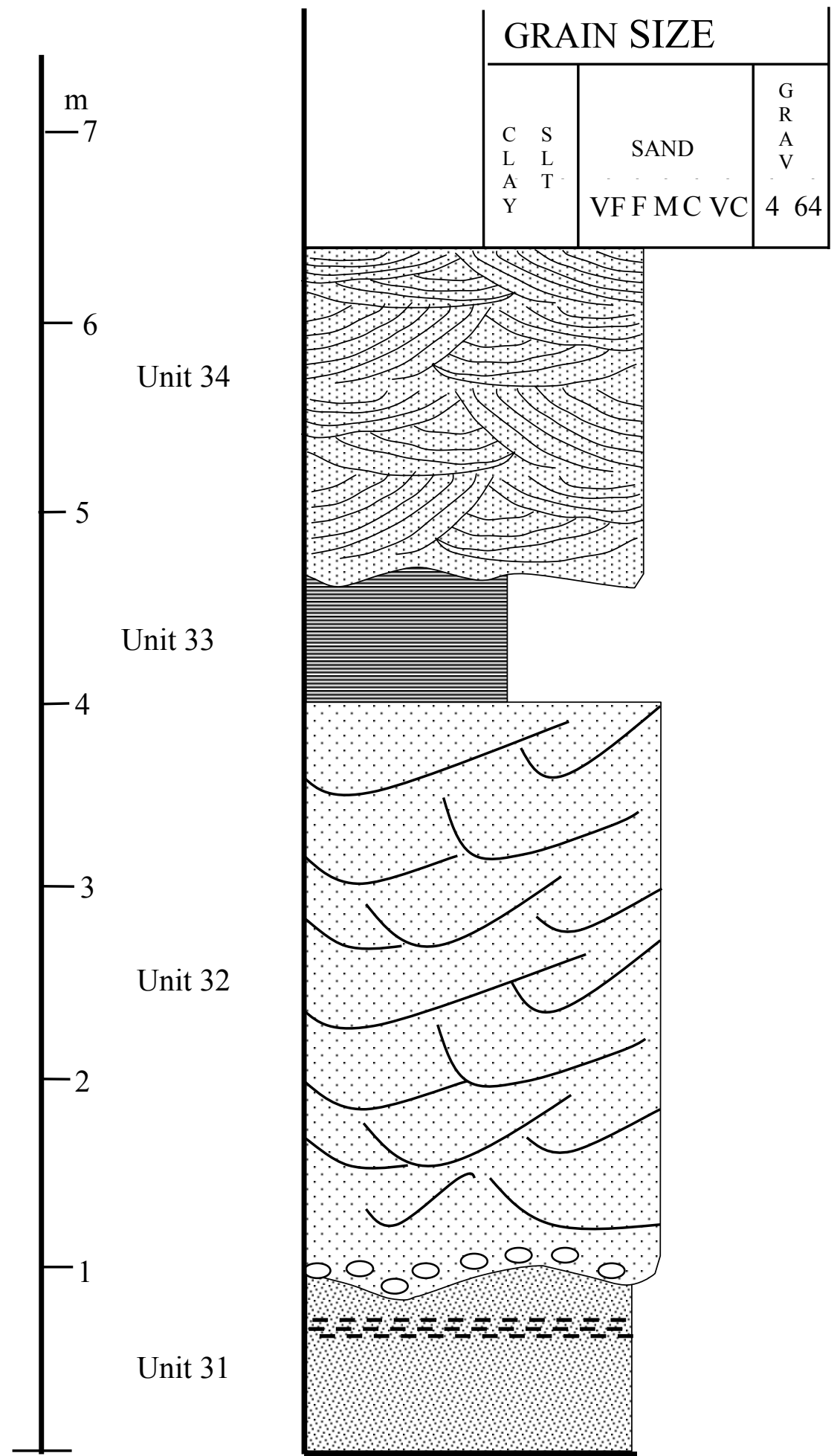

Unit 33
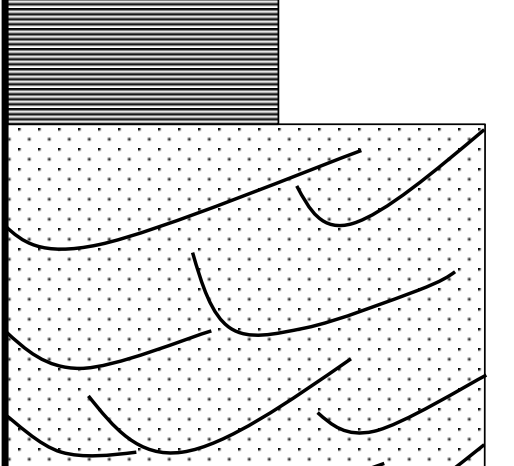

Unit 32

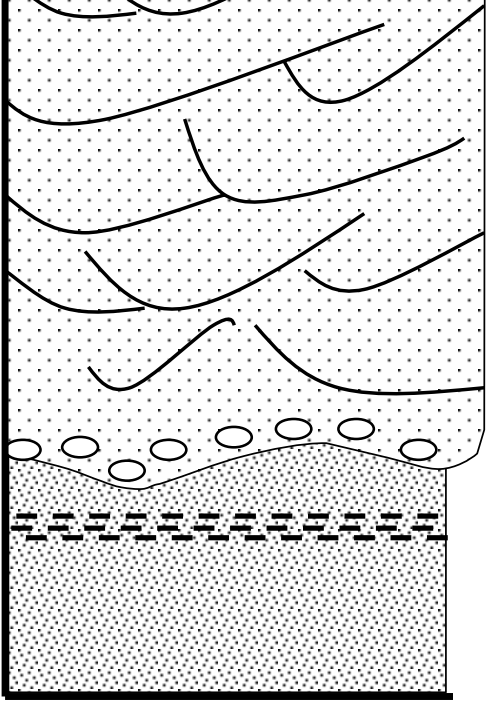

Figure 10C: Continuation of outcrop 4 stratigraphic column. 


\section{Outcrop 5 \\ 12.12 total meters exposed}

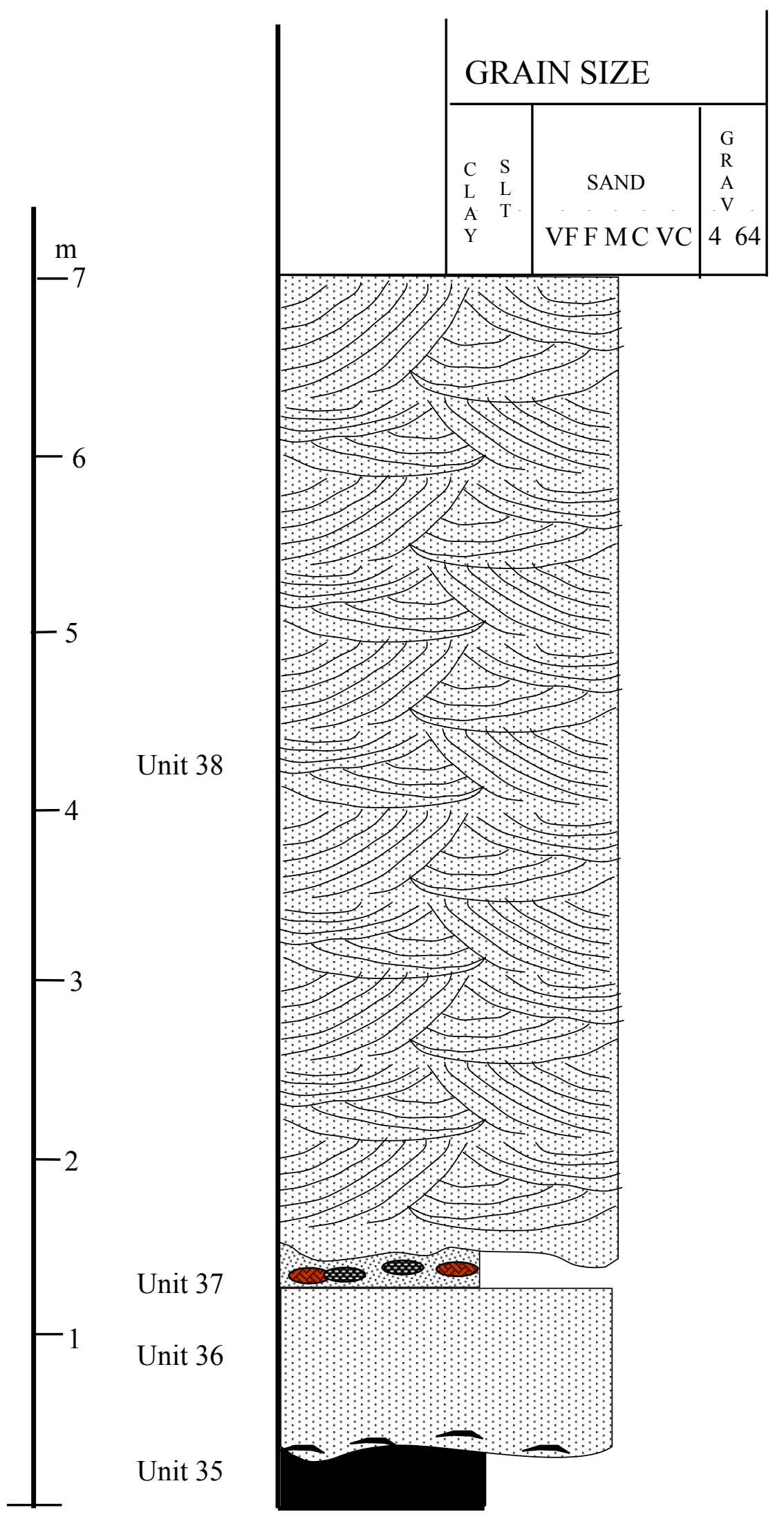

Figure 11A: Outcrop 5 stratigraphic column. 


\section{Outcrop 5 \\ 12.12 total meters exposed}
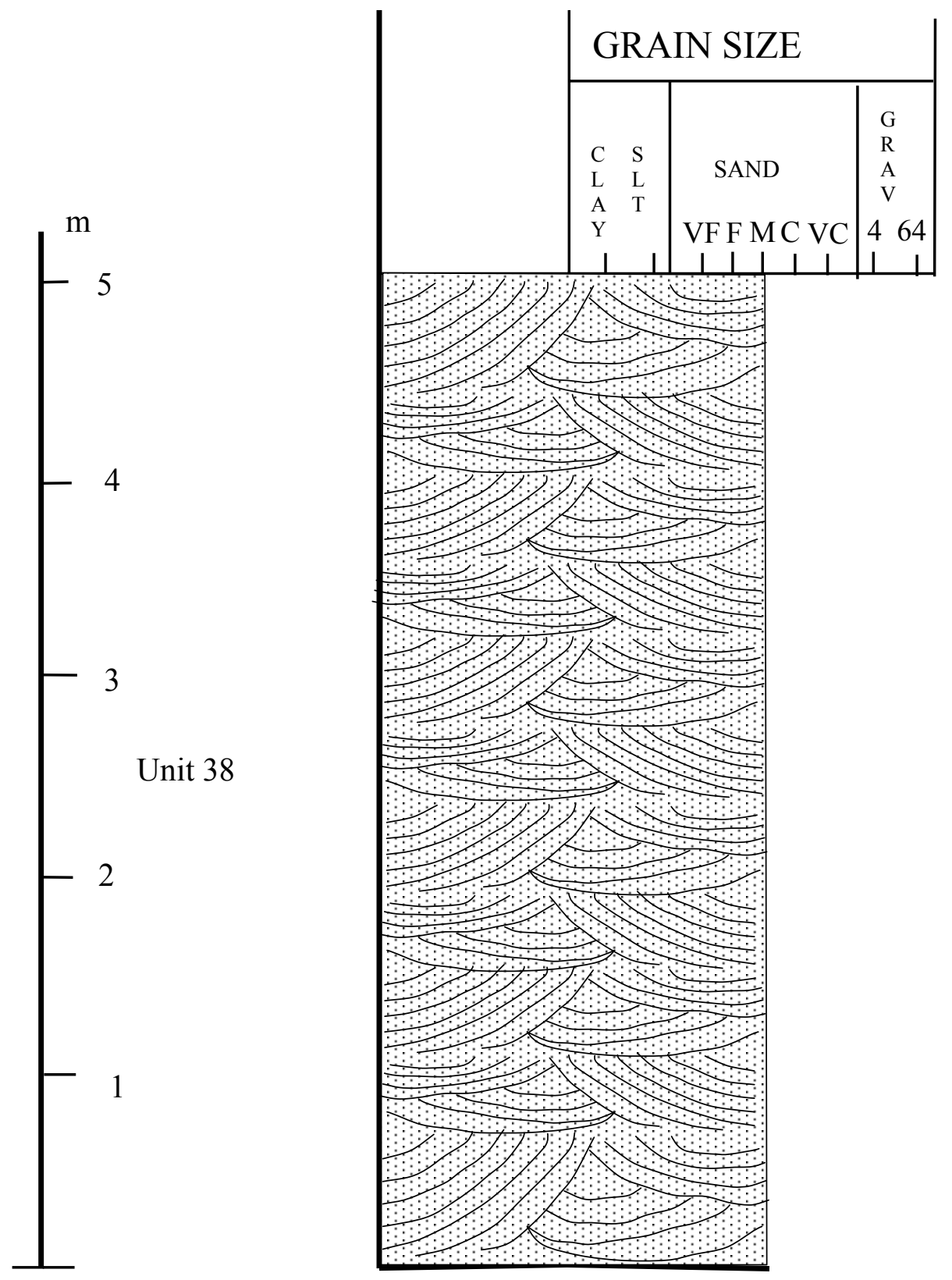

Figure 11B: Continuation of outcrop 5 stratigraphic column. 


\section{Outcrop 6 9.2 total meters exposed}

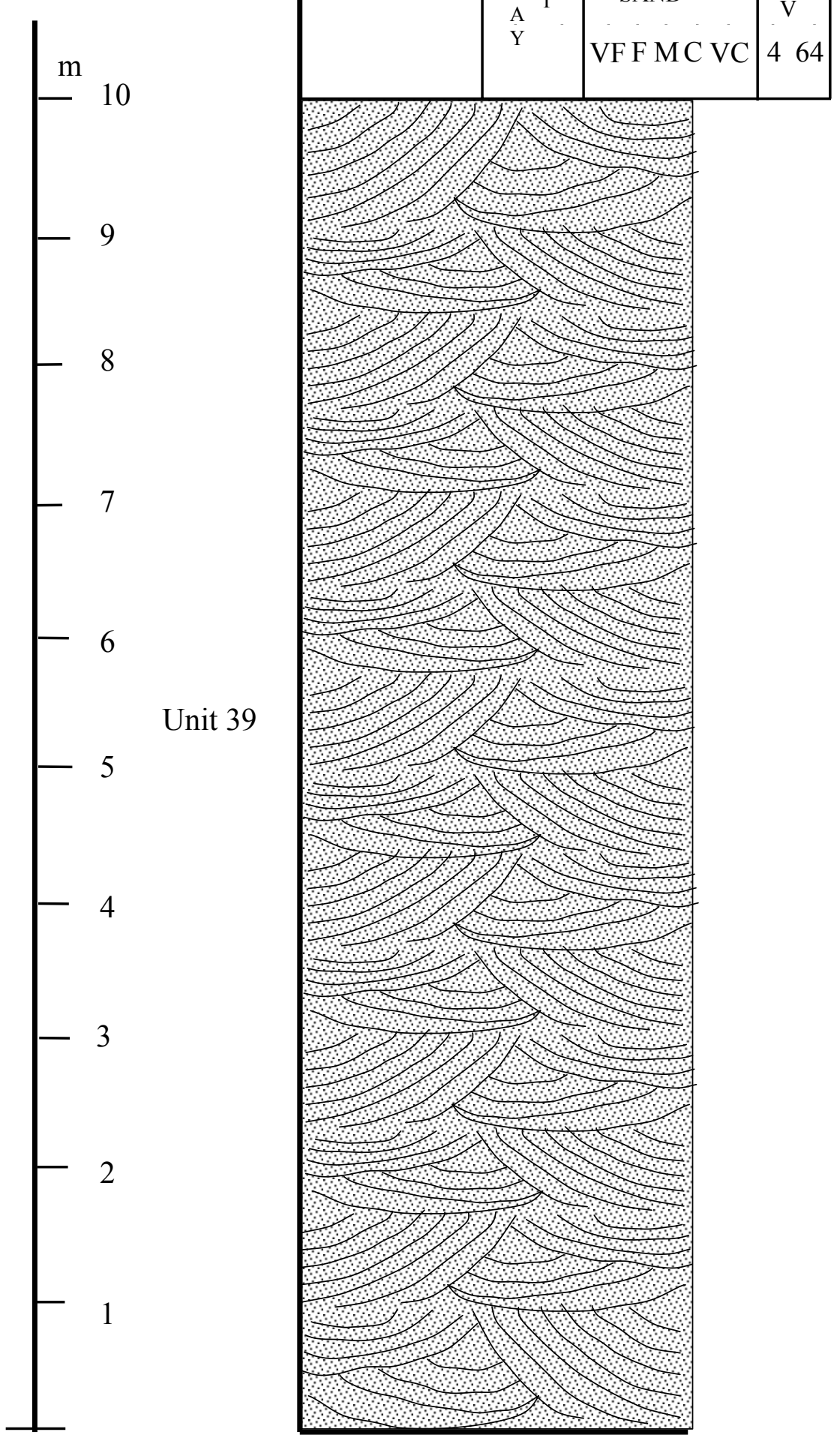

Figure 12: Outcrop 6 stratigraphic column. 


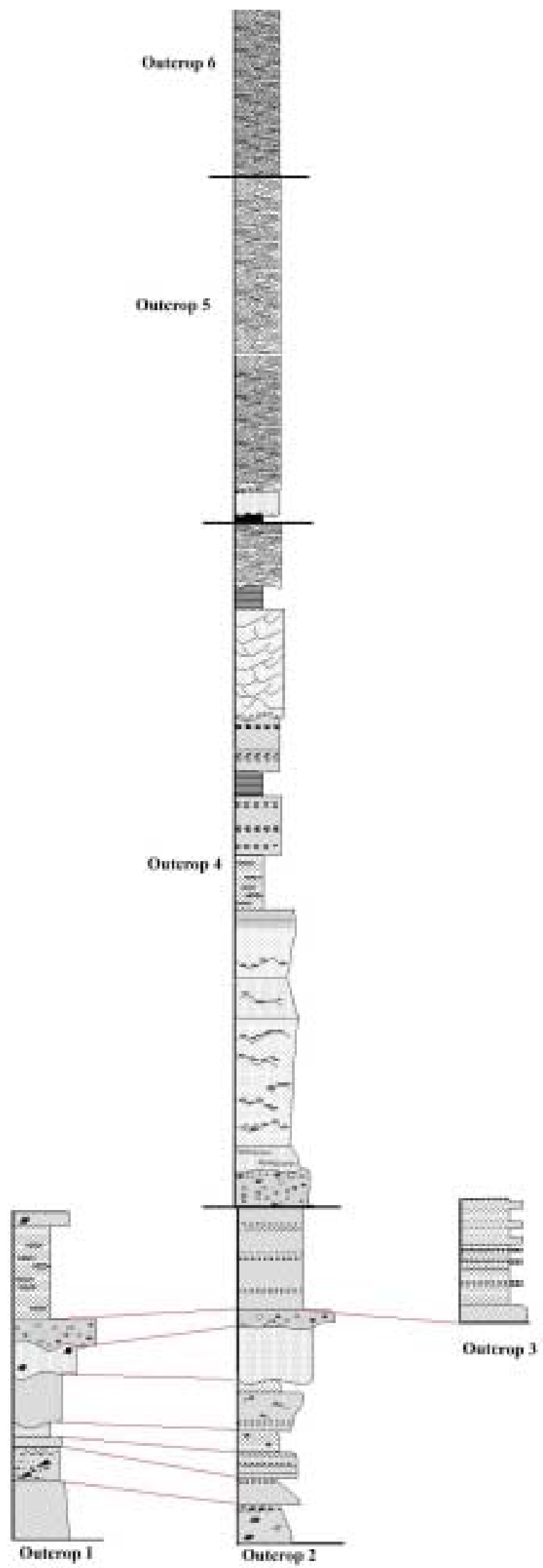

Figure 13: Composite stratigraphic column for all 6 outcrops showing the relationship between outcrops. 


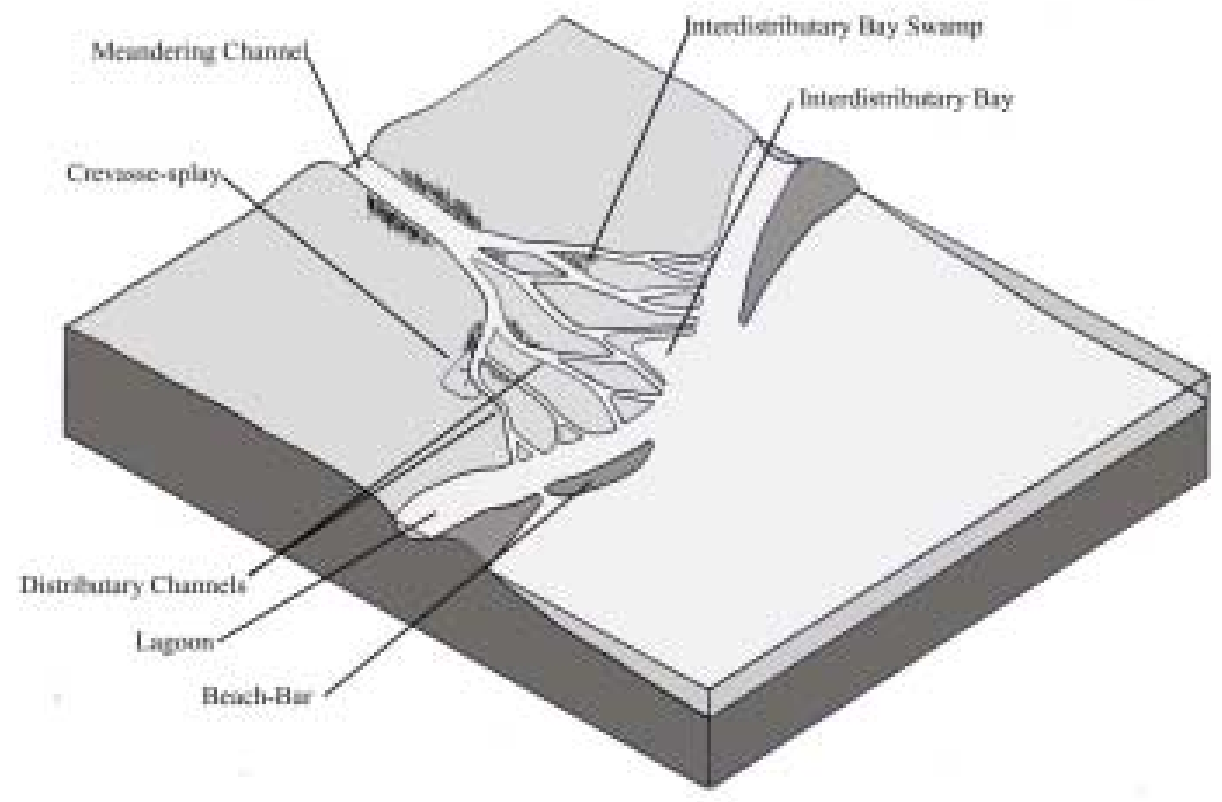

Figure 14: Hypothetical 3-D model of the Price Formation exposed at Sherwood Lake. 
channels, which in fluvial-dominated deltas can be bays, floodplains, marshes, or swamps (Reading and Collinson, 1996; Orton and Reading, 1993). The upper portion of a delta plain is entirely unaffected by basinal or marine processes, and therefore does not differ significantly from alluvial environments. Facies within the upper-delta-plain are wholly fluvial in nature and consist of fluvial channels, distributary channels, swamps and crevasse splays.

The lower-delta-plain extends from the landward limit of tidal influence down to the shoreline; it reflects both river and marine interaction. Generally speaking, the distributary channels divide and become broader and shallower as they move seaward where they eventually lose their identity. The environments between the numerous channels comprise the largest percentage of the lower-delta-plain and consist mainly of interdistributary bays, lagoons, estuaries, as well as some crevasse-splays and marshes. Figure 15 illustrates the typical coarsening-upward sequence present within the lowerdelta-plain.

\section{Meandering Channel Facies}

Upper-delta-plain facies present at the Sherwood Lake outcrops that are entirely fluvial in origin occur at outcrop 6 (unit 39; Figure 12). Exposed is a $9.8 \mathrm{~m}$ section of medium-grained sandstone. Sedimentary structures include very prominent, large-scale planar cross-beds (15 - 100 thick) and scour-and-fill structure; however, evidence of fining-upward sequences is not visible at outcrop (Figures 16-19). Multiple channels scour into each other with an average thickness of $1 \mathrm{~m}$ and a width of $6 \mathrm{~m}$. Occasionally, planar cross-bed sets have fissile bedding, with sandstone beds as thin as a few 


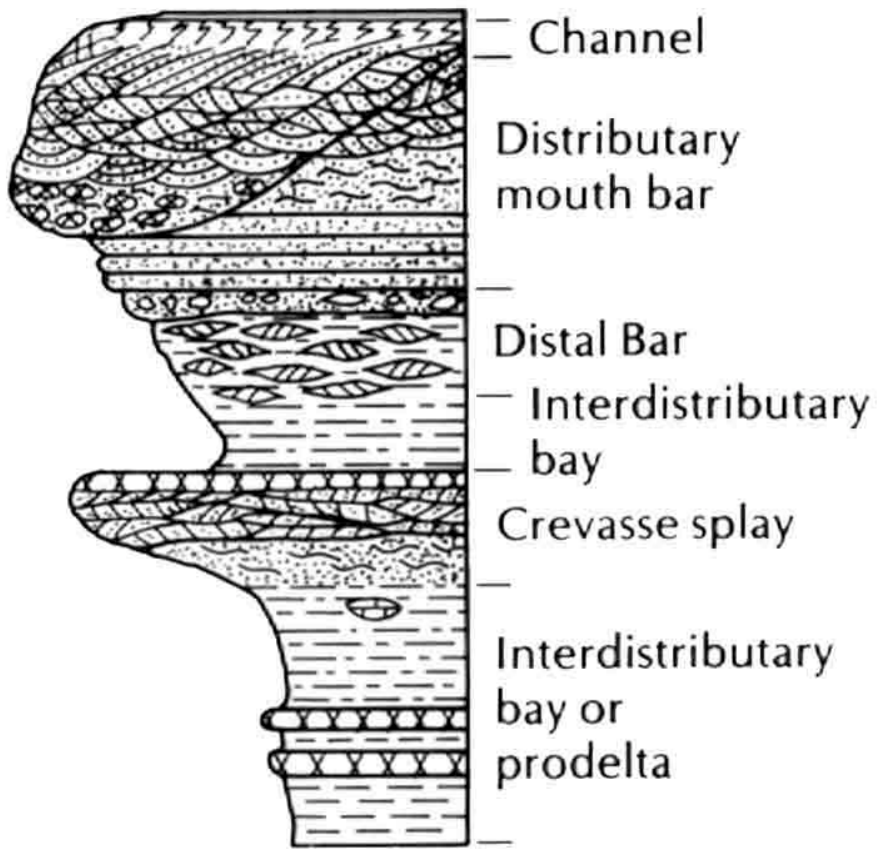

Figure 15: Typical coarsening-upward sequence through the lower-delta-plain deposits (Prothero, 1990). 


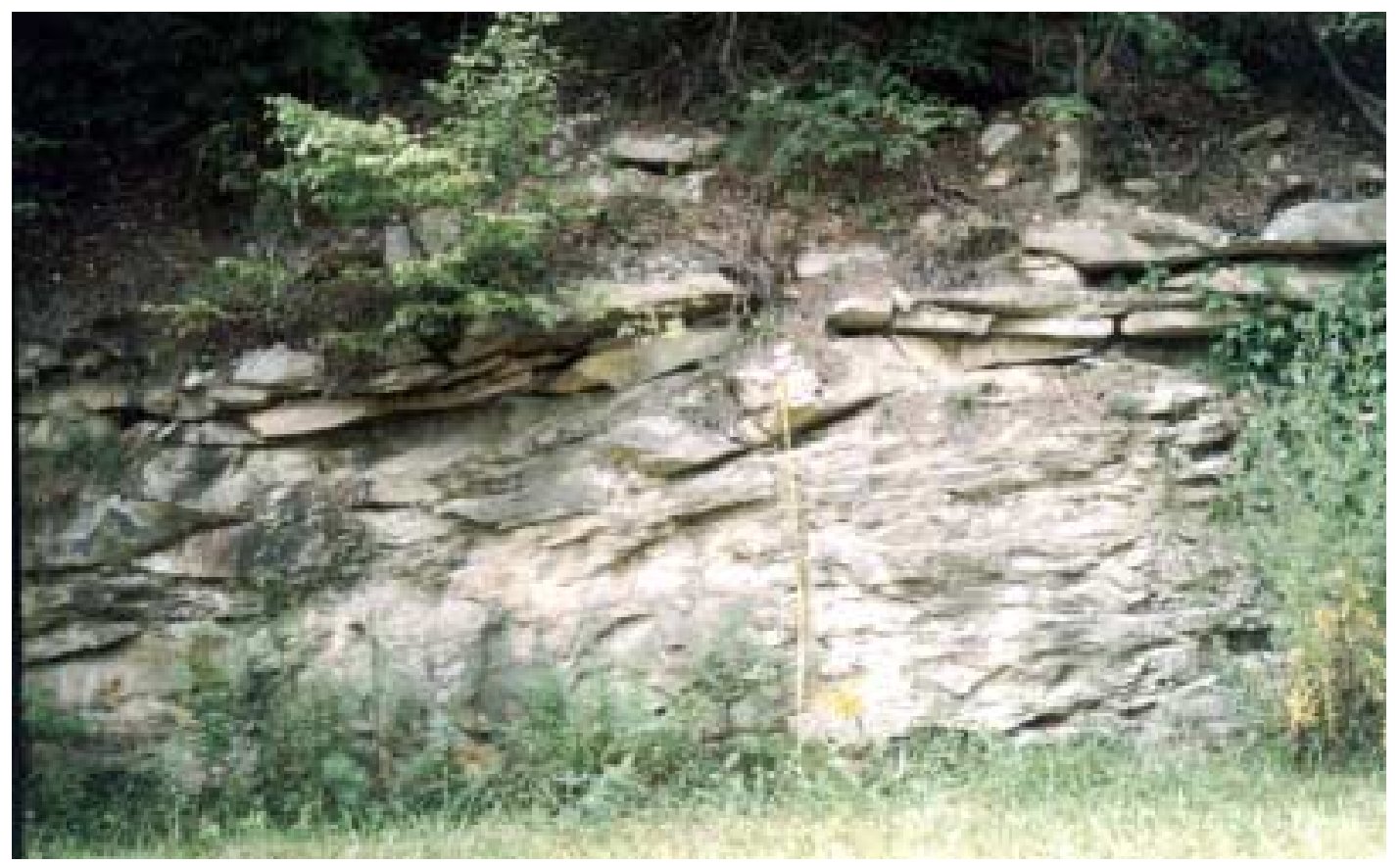

A.

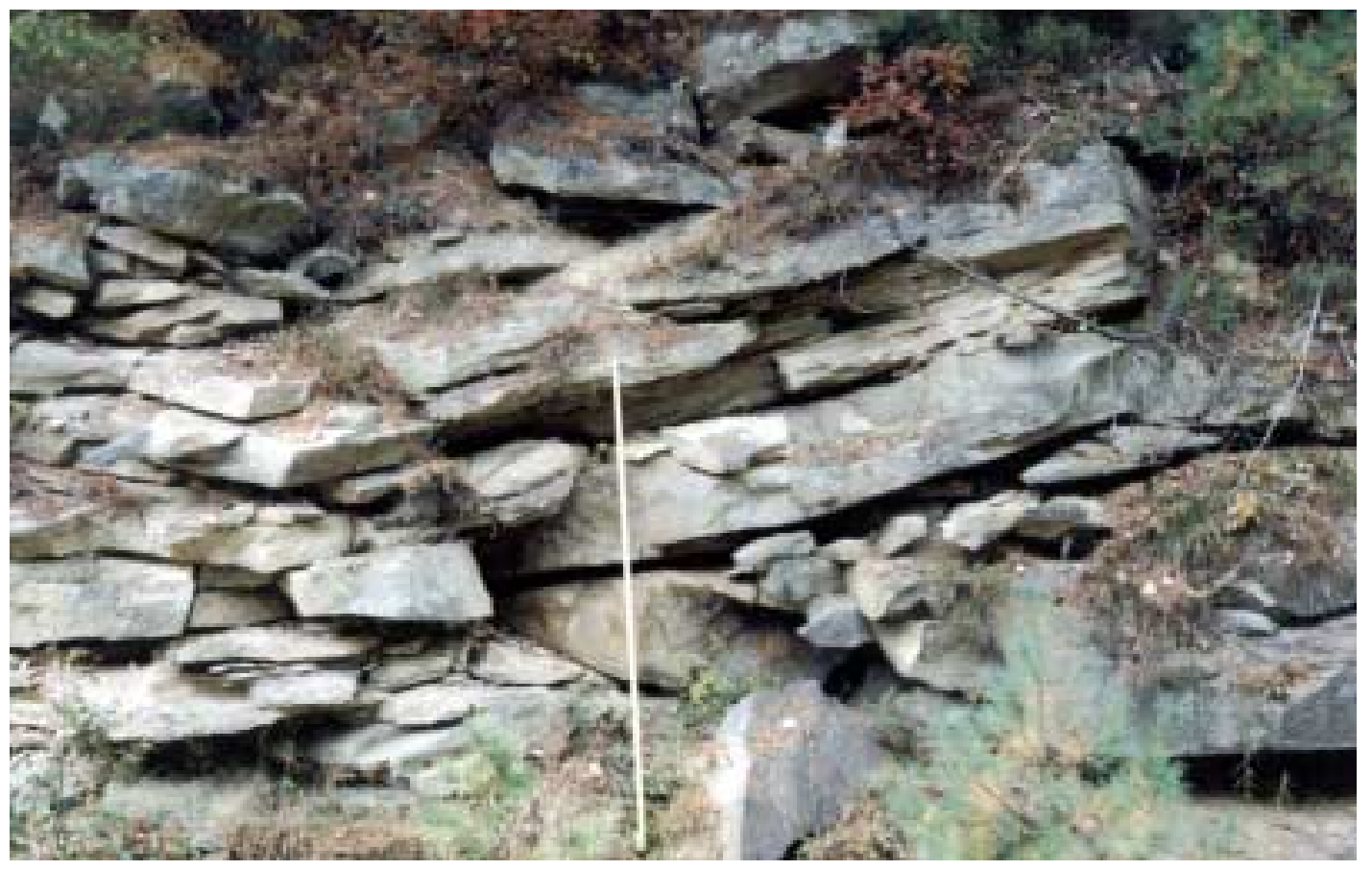

B.

Figure 16: Photographs of fluvial facies of Unit 39 within outcrop 6. Tape measure equals 2 meters. 


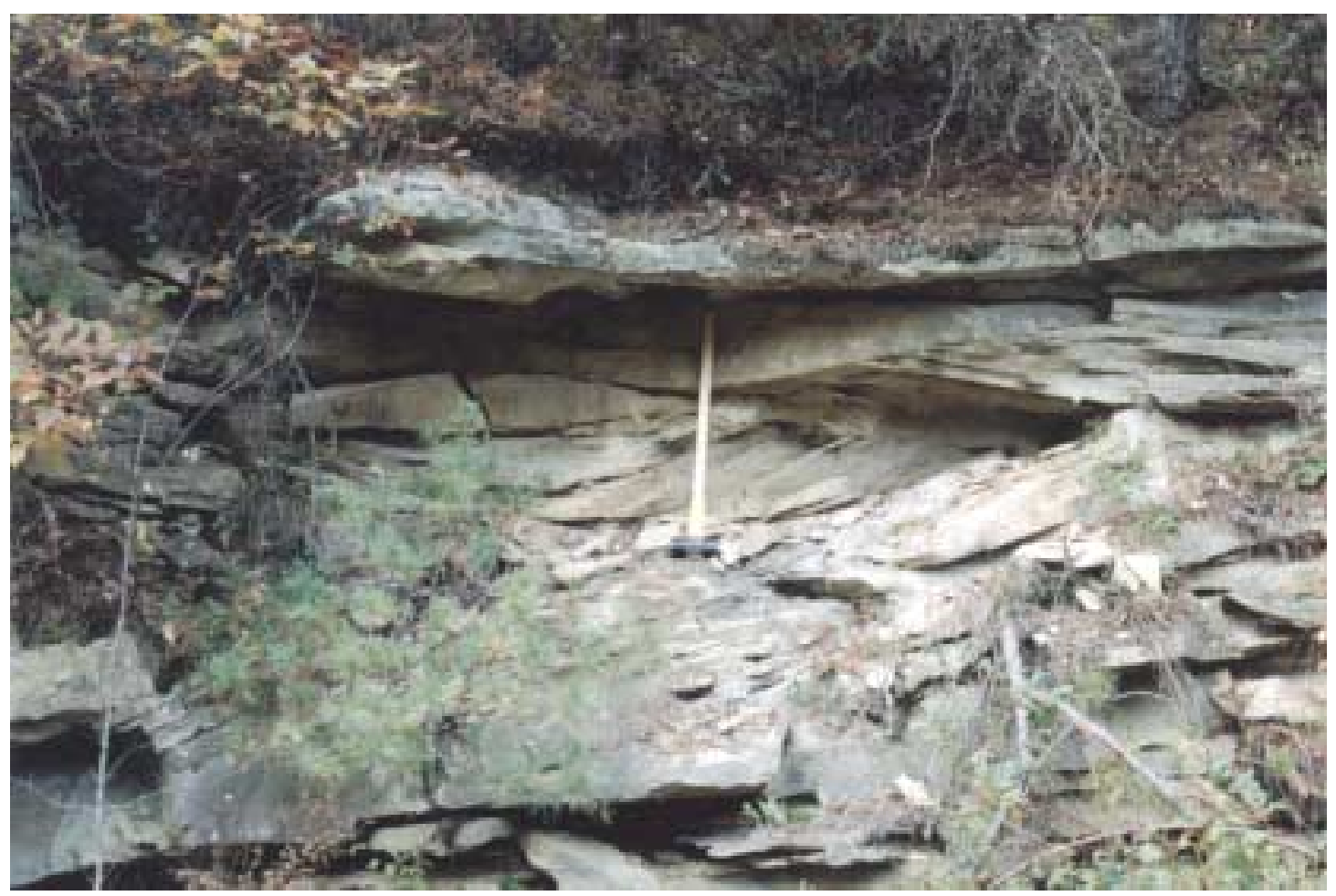

A.

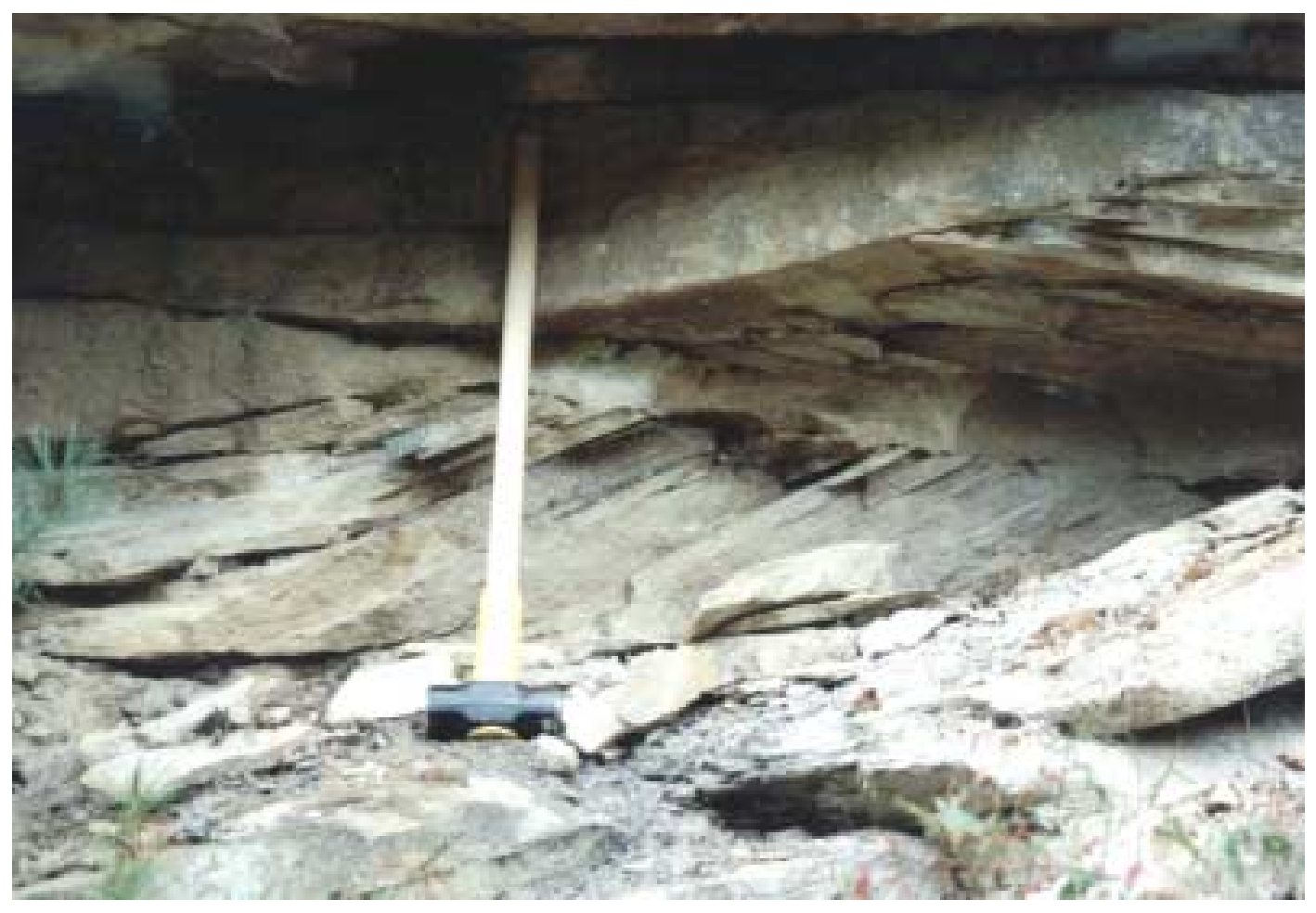

B.

Figure 17: Large-scale trough cross-beds of the fluvial facies, unit 29. Note fissile bedding in close up view (B). 


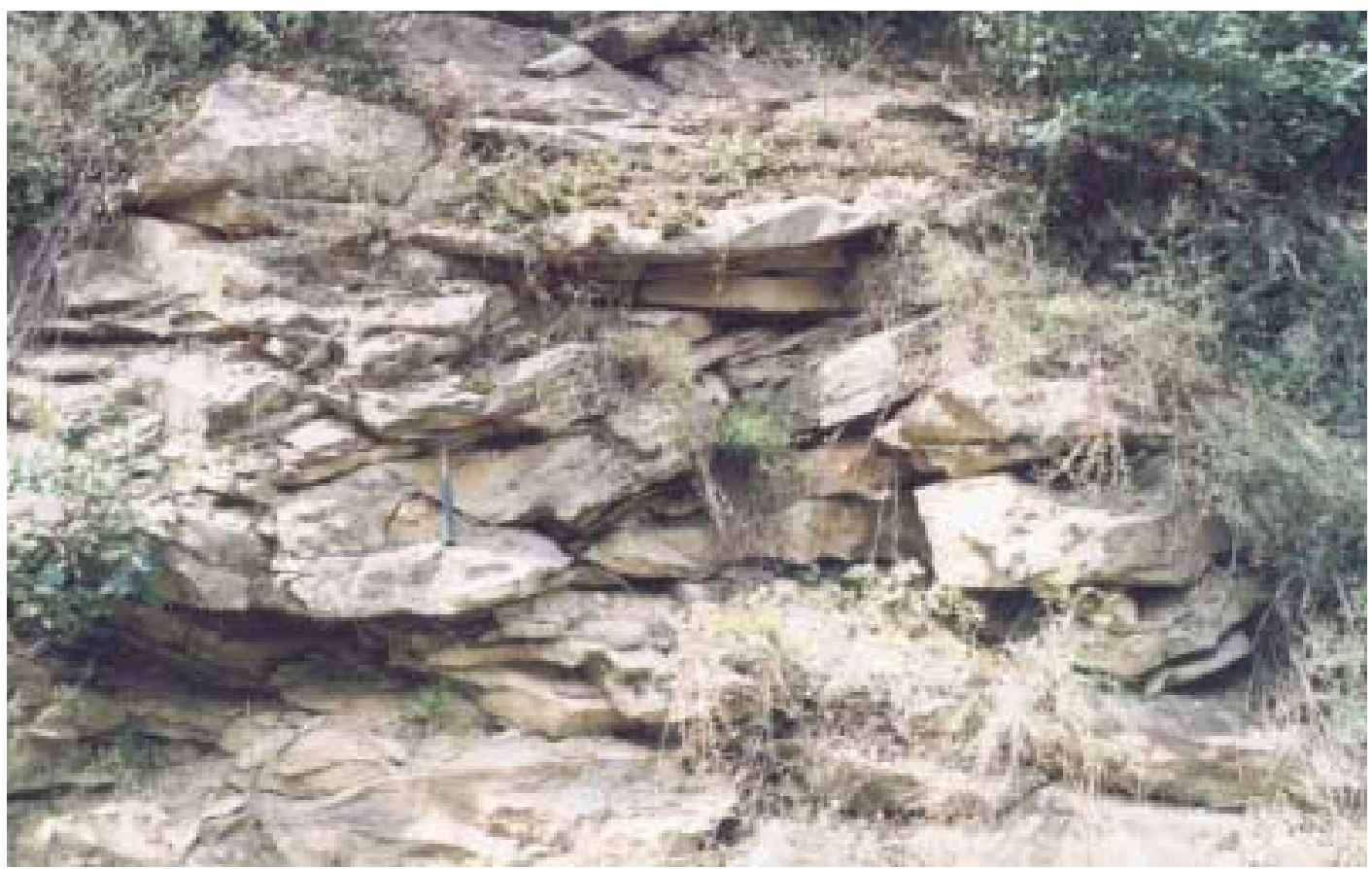

A.

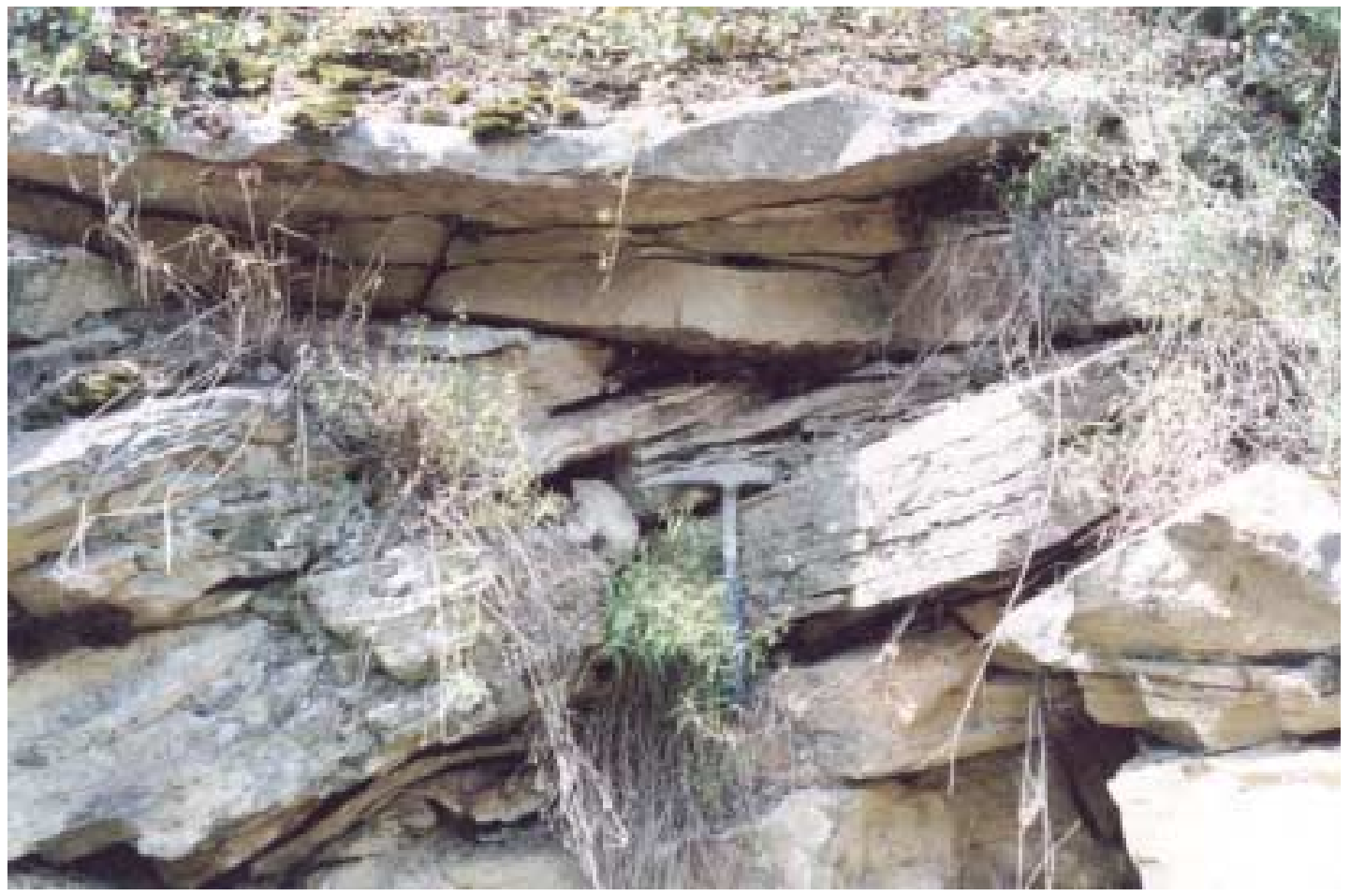

B.

Figure 18: Fluvial sandstone displaying scour-and-fill structure, unit 39. B is a close of view of $\mathrm{A}$. 


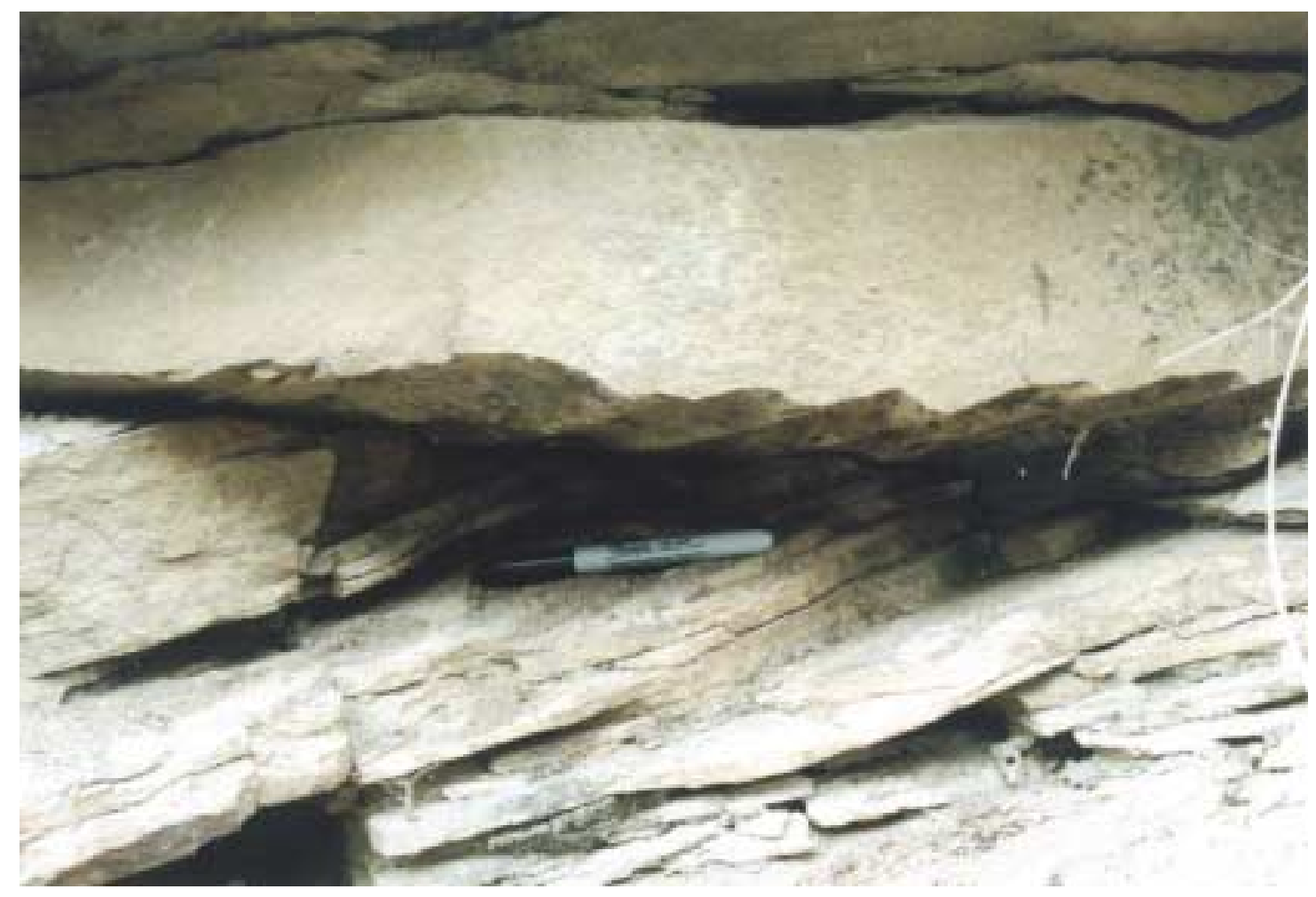

Figure 19: Close-up view of scour-and fill structure, unit 39 (in Figures 17 A and B). 
centimeters. Small amounts of organic debris, presumably plant remains, were found on the bottom of beds within the facies. Fluvial facies are usually categorized into four channel patterns: meandering, straight, braided, and anastomosed (Miall, 1992). Meandering-river deposits are present in the Price Formation at Sherwood Lake. Meandering rivers are characterized by point-bar deposits (sandstone) that typically have a basal conglomeratic lag deposit of caved bank material, waterlogged plant material or pebbles of the thalweg. The rocks generally show a fining-upward sequence that is dependent on meander sinuosity and flow patterns of the river (Cant, 1982; Miall, 1992).

Figure 20 shows an example of the typical sequence found in meandering-river systems. The fining-upward sequence begins with a clast-rich conglomerate at the base, which is overlain by trough cross-bedded to parallel-laminated point bar sands moving up to finer-grained rippled sand, and finally the sequence is capped by levee and overbank silt and mud.

The deposits at Sherwood Lake, however, are multistory sandbodies that are made up of several channel units. Multistory sandbodies consist entirely of vertically stacked cosets of large-scale cross-strata. Areas of trough cross-bedding (formed by the amalgamation of channel deposits from a single sinuous channel) are separated by thicker zones of planar cross-bed sets. The trough cross-beds indicate periods of more persistent channel flow, whereas the planar cross-strata indicate deposition in relatively quiet areas within the channel's migration pattern, such as sandflats (Collinson, 1996). Large-scale cross-beds also display wide variations in current-directional properties, primarily because of the sinuous nature of the channel and its tendency to migrate (Coleman and Prior, 1982). 


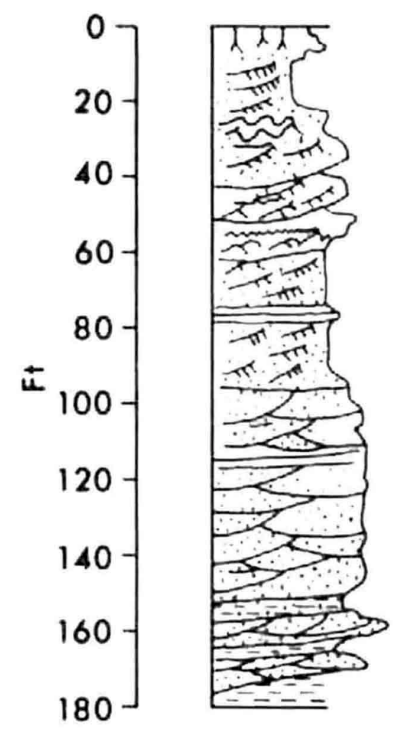

Small scale x-lam., ripple drift

abund., rooting \& burrowing common

Lg. scale $x$-bod. sets displaying

sm. scale $x$-lam. \& climbing

ripples, large scale contorted

bedding at top of sand.

X.lam., climbing ripplos, planar

lam., thin cl. layers.

Lg. x-bed., scour-filled scat.

org. dobris

Cl.sd., scour-fill, slump blk., load casts, logs, thin $\mathrm{cl}$. layers.

Figure 20. Typical fining-upward sequence of meandering river deposits (Coleman and Prior, 1982). 
Typically, few overbank sediments are preserved within the sandbodies mainly as a result of the active channels' mobility and the erodibility of the bank material. Any mudstone and siltstone deposition is restricted to overbank deposition on floodplains or on the tops of any mid-channel islands present. When and if overbank deposition occurs, more often than not the deposits are cannibalized by the river's own channel migration.

Multistory sandstones are considered to be the products of rather mobile river systems in which the channel and bar shift at a variety of physical and temporal scales (Collinson, 1996). For example, shifting of the channel can occur from large-scale physical changes such as climatic changes and seasonal fluctuations, or can be a result of small-scale temporal changes such as channel plugging due to a build-up of organic debris. Often times, meandering river systems are bordered by cohesive peat mires, which tend to be extremely stable and difficult to erode (Figure 21a). Adjacent channels must migrate within a restricted and localized area, therefore causing deposition to occur in multistory complex (Figure 21b).

Unit 39 , exposed at outcrop 6 , is $10 \mathrm{~m}$ of a multistory sandbody similar to those described by Collinson (1996). The unit is a well-sorted, medium-grained sandstone that contains a small amount of fine material (shale and clay particles), as well as a general lack of coarse sediments, indicating a narrow range of grain sizes within the unit. The lack of a fining-upward sequence within the unit can best be attributed to this small range in particle size. Most likely, by the time the sediments within the fluvial system were deposited, the grains were moderately well sorted due to the oscillating nature of the 
(a)

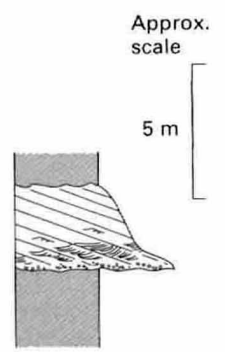

(1)

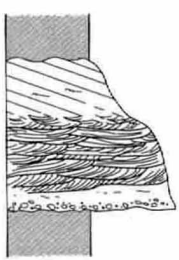

(2)

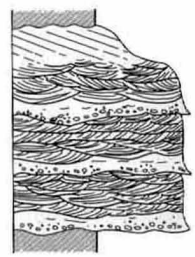

(3)

(b)

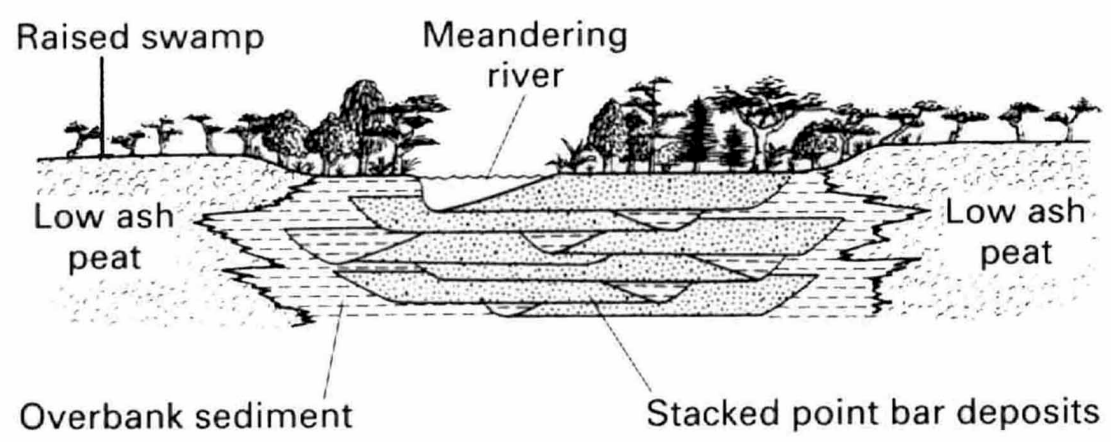

Figure 21: (a) Examples of lateral accretion cross-bedding in small channel sandbodies. (1) Lateral accretion occupies the full thickness of the sandbody. (2) Lateral accretion bedding that is only apparent in the uppermost units, where (3) illustrates a multistory example of (2) (Collinson, 1996). (b) A model for fluvial deposition yielding multistory sandbodies. The bordering swamps inhibit overbank flooding and prevent avulsion, causing the channel to migrate within a fixed belt and give stacked multistory sandbodies (Collinson, 1996). 
river. The large-scale planar cross-beds within unit 39 are probably a result of migrating sand waves on the channel floor, where as the scour-and-fill structures that are present are a result of fluvial erosion. Both structures vary in their thicknesses (Figures 18-19).

\section{Distributary Channel Facies}

Upper distributary channel facies can be seen at outcrop 5 (Figures 11 A and B), unit 38, where fine to medium-grained sandstone ranges in thickness from 1.5 to $10 \mathrm{~m}$. Lower distributary channel facie at outcrop 4 are from 2 to 4 m thick units of fine to medium-grained sandstone (units 32 and 34). At both outcrops the sandstone beds appear to be massive in nature, but a closer look yields bedding that changes upward from medium $(0.1-0.3 \mathrm{~m})$ to thin $(0.03-0.1 \mathrm{~m})$. Present are large-scale planar and trough cross-beds as well as multiple channels that cut into one another (Figure 22). Where the channels are best exposed, the average channel thickness is $2.5 \mathrm{~m}$ and 5 meters in width. Common in the facies are scoured basal contacts with, small basal pebble conglomerates that consist of large grains of rounded quartz, siderite nodules as well as shale clasts which are present in some of the units, and begin the fining-upward sequences present in all outcrops. Wavy bedding and a rippled upper surface are common sedimentary structures present in the sandstone beds as well.

Generally speaking, the fluvial facies of the delta grade downslope into the distributary facies. Distributary channels are very similar to fluvial systems, but differ only in their size and position on the delta plain. The distributary channels carry water and sediments from the main stream across the delta to the sea. In some cases deltas may have only one channel (van Gelder et al., 1993), but more commonly a delta consists of a series of distributary channels that are variably active across the delta plain (Orton and 


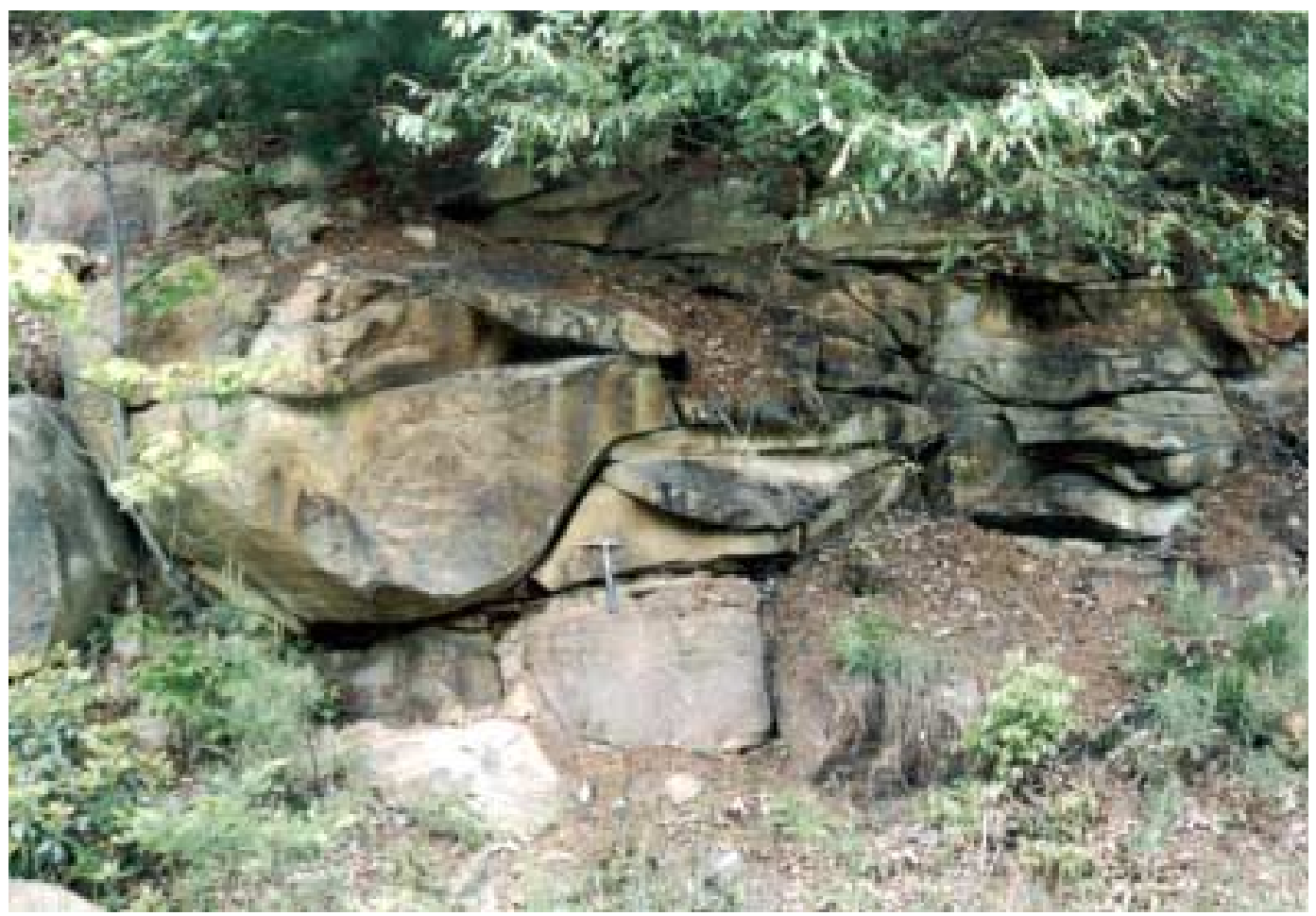

A.

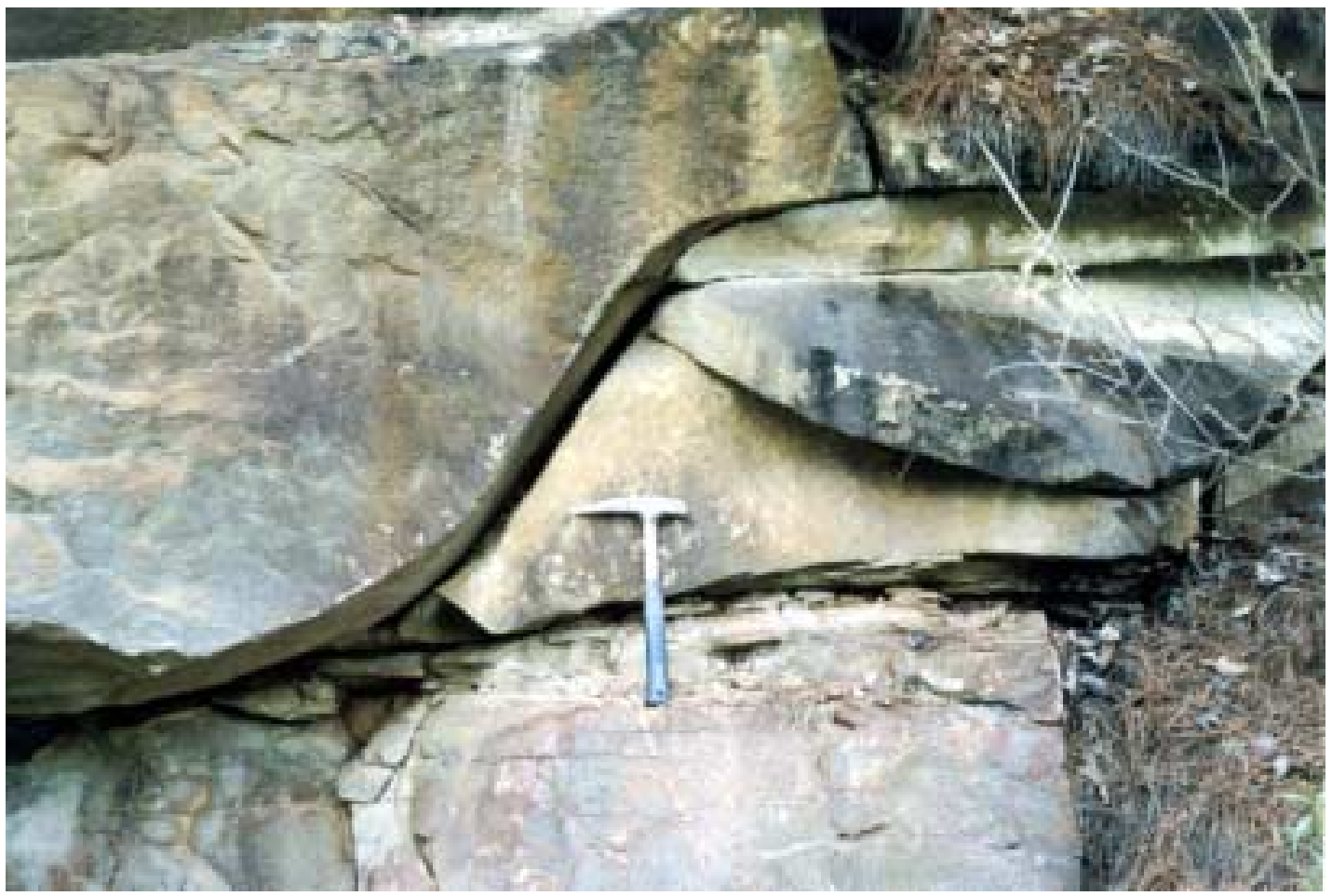

B.

Figure 22: Upper distributary channels located at outcrop 5, unit 38. B is a close-up view of $A$. Figures show channel deposits scouring into one another. 
Reading 1993; Reading and Collinson, 1996). The resultant deposits are sands with eroded basal contacts often with a basal lag that fine upward through cross-bedded sand into ripple-laminated fine sand with silt and clay interbeds. The most common sedimentary structures found in distributary channel deposits are cross-bedding, current ripple bedding, scour-and-fill structures and erosional surfaces. Where clay layers escape total erosion, they usually show scour features; where erosion has occurred, clay fragments are incorporated within the overlying sandy sediments (Reineck and Singh, 1980). Although this fining-upward sequence is common, in some deposits there is virtually no change in grain size upsection, which may be dependant upon the rapidity of infilling or local subsidence. Where infilling and/or local subsidence occurs rapidly, grain size will show little to no variation, and may continue for meters of deposition.

Distributary channels vary considerably in size, some being a few meters in width and 1 to 2 meters deep, whereas others of a large major river delta system reach $1 \mathrm{~km}$ in width and 30 meters in depth. Depth decreases rapidly as the distributary-mouth bar is approached (Coleman and Prior, 1982).

Figure 23 expresses the common fining-upward sequence of a distributary channel. Facies successions through distributary channels have a scoured base, and filling commonly takes place during and after channel switching. Normally fluvially derived facies are preserved at the base, and thin erratic layers of sand and silt, alternating with clays, are preserved towards the top. The upper-delta-plain distributary-channel deposits found at Sherwood Lake do not necessarily show this entire sequence, but rather preserve a portion of the succession. Sherwood Lake distributary channels that were deposited on the lower-delta-plain better show this characteristic sequence. This may be 


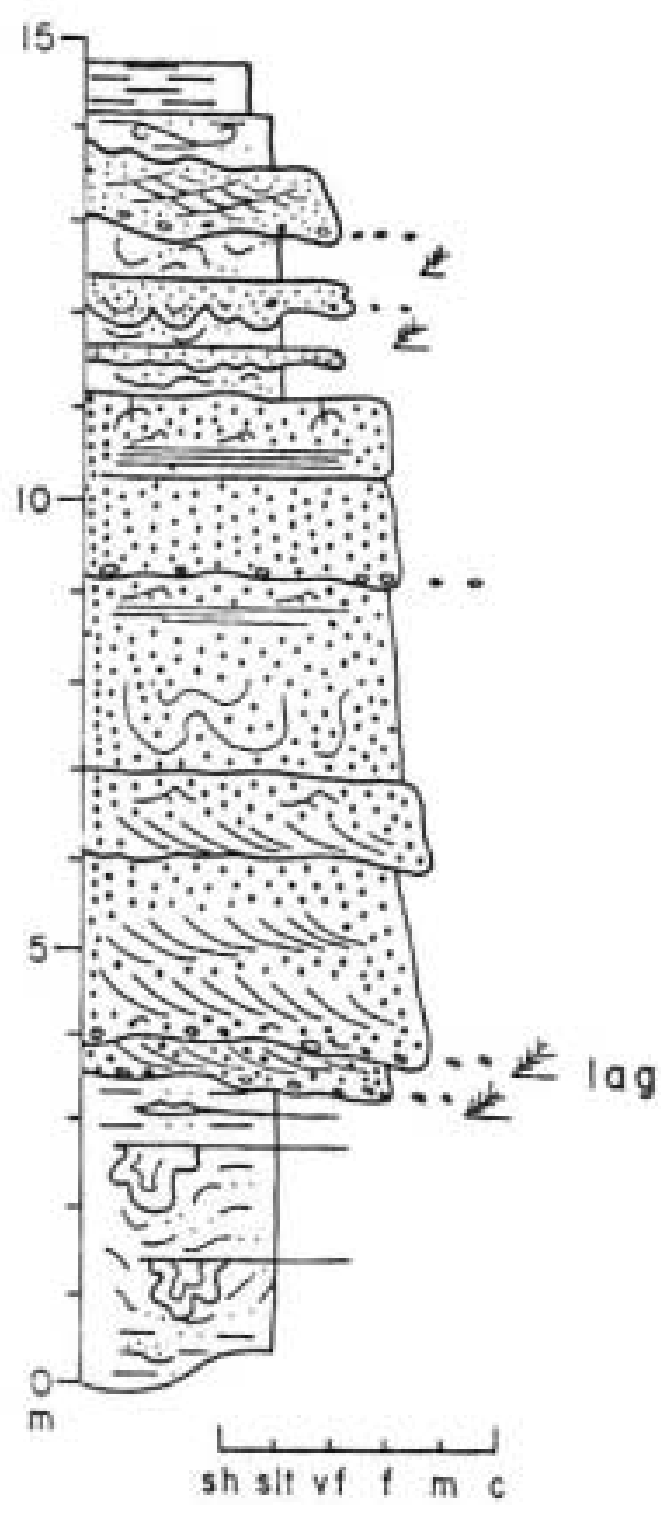

Figure 23. Typical fining-upward sequence found within a distributary channel facies (Bhattacharaya and Walker, 1992) 
because distributary channels that are located on the upper-delta-plain tend to be more confined to their channel, and in many aspects are comparable to the fluvial facies at Sherwood Lake. In these facies the stream is confined to its channel where it may cannibalize itself to the point where no fines are preserved. Especially if the systems are well sorted to begin with, a change in grain size may not be detectable. On the lowerdelta-plain, however, distributary channels divide and become broader, and no longer are as confined to the channel as those distributary channels on the upper-delta-plain. As a result, a broader range of particle size is present within those distributary channels on the lower-delta-plain. Siderite nodules from the adjacent interdistributary areas, as well as quartz grains, make up the majority of the coarser-grain particles. Fines commonly are preserved because the channels are not switching as frequently as those channels on the upper-delta-plain. Upper-delta-plain distributary deposits are represented by unit 38, and is located at outcrop 5 (Figure 24). Units 32 and 34 of outcrop 4 represent distributary deposits that were deposited within the lower-delta-plain (Figure 25).

\section{Crevasse-Splay Facies}

Crevasse-splay facies consists of over 1 meter of fine to medium-grained sandstone (units 36 and 37) that can be seen in outcrop 5. Grain size ranges from coarse sand and pebble-sized shale/coal rip-up clasts to fine sand. A scoured basal contact marks the beginning of each unit. The overlying sandstone is extremely dirty, and loaded with coal and shale rip-up clasts. Also present are prominent load structures and a finingupward sequence, and some small trace fossils. The most distinguishing feature of this unit however, is the color of the sandstone beds, which is a bright-orange red (Figure 26). 


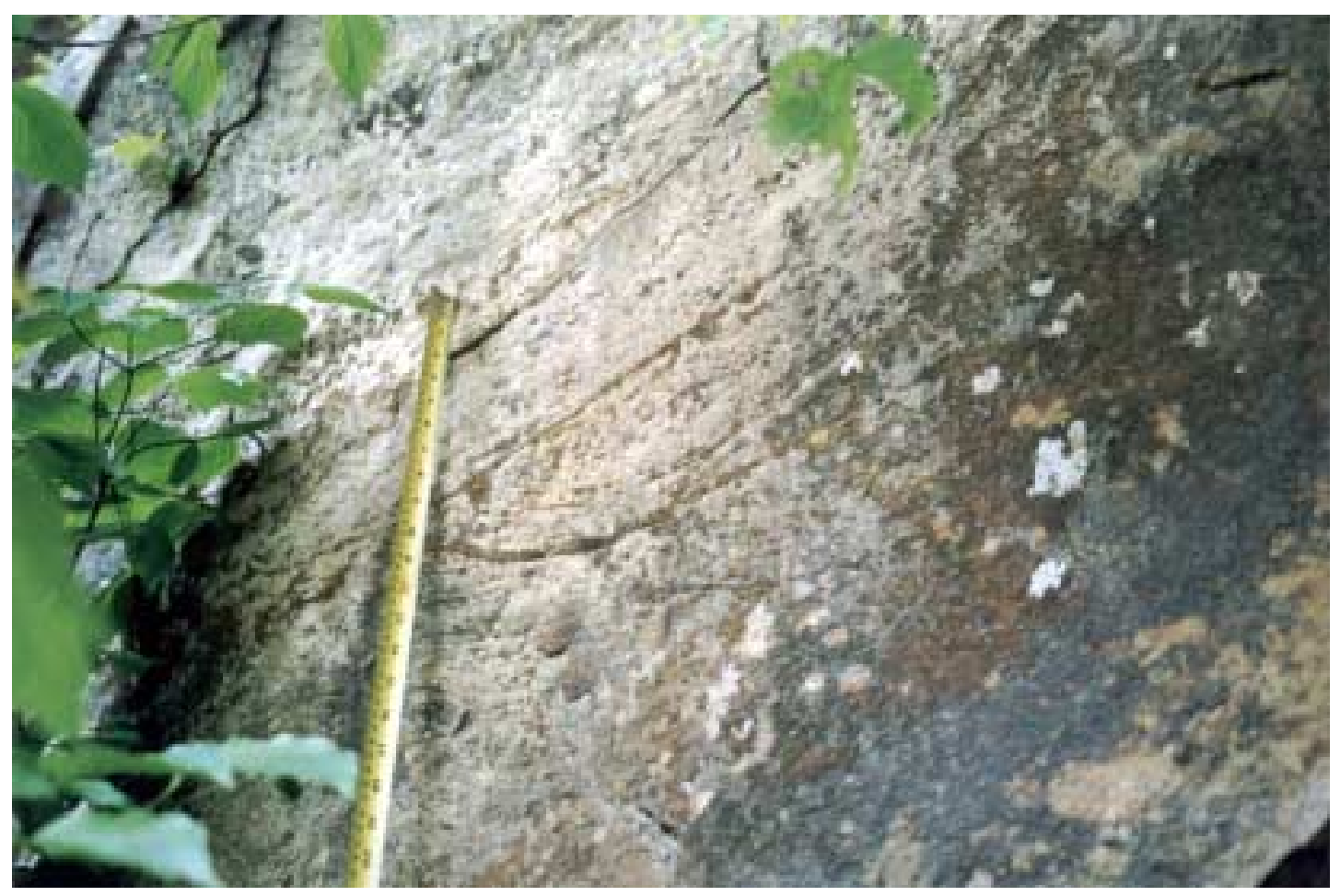

Figure 24: Unit 38- Upper distributary channel large-scale trough cross-beds

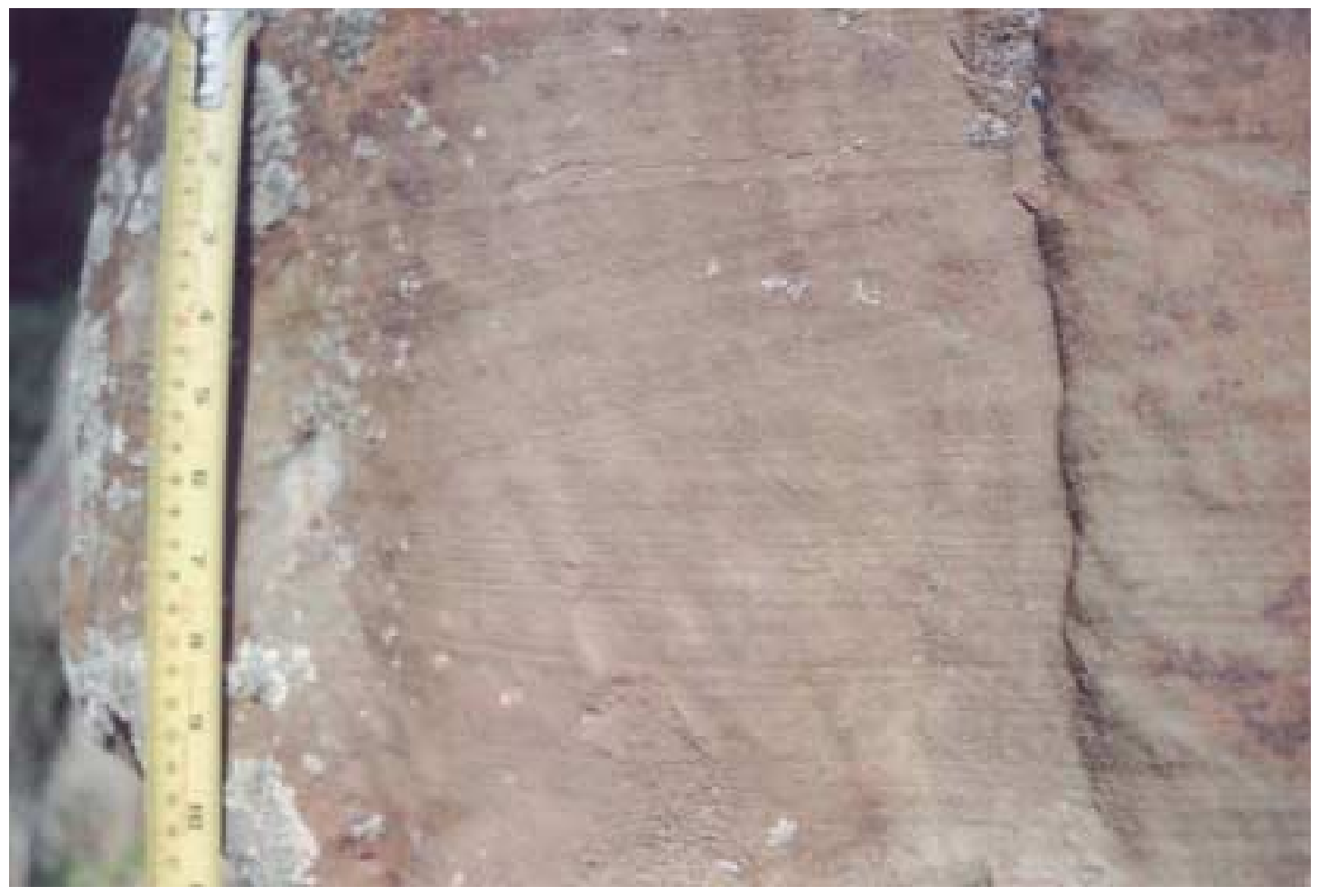

Figure 25: Unit 34- lower distributary channel, large-scale planar cross-beds. 


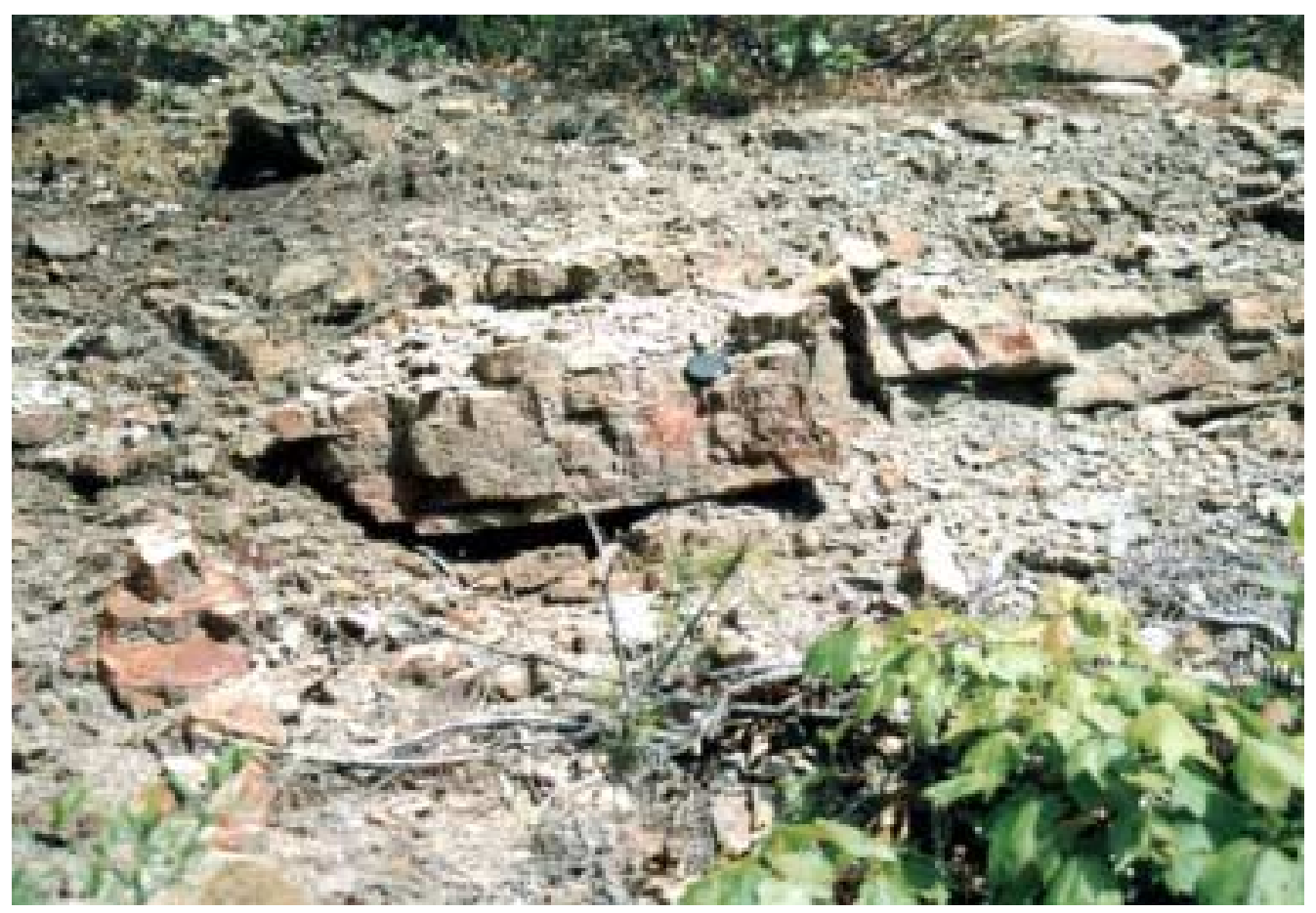

A.

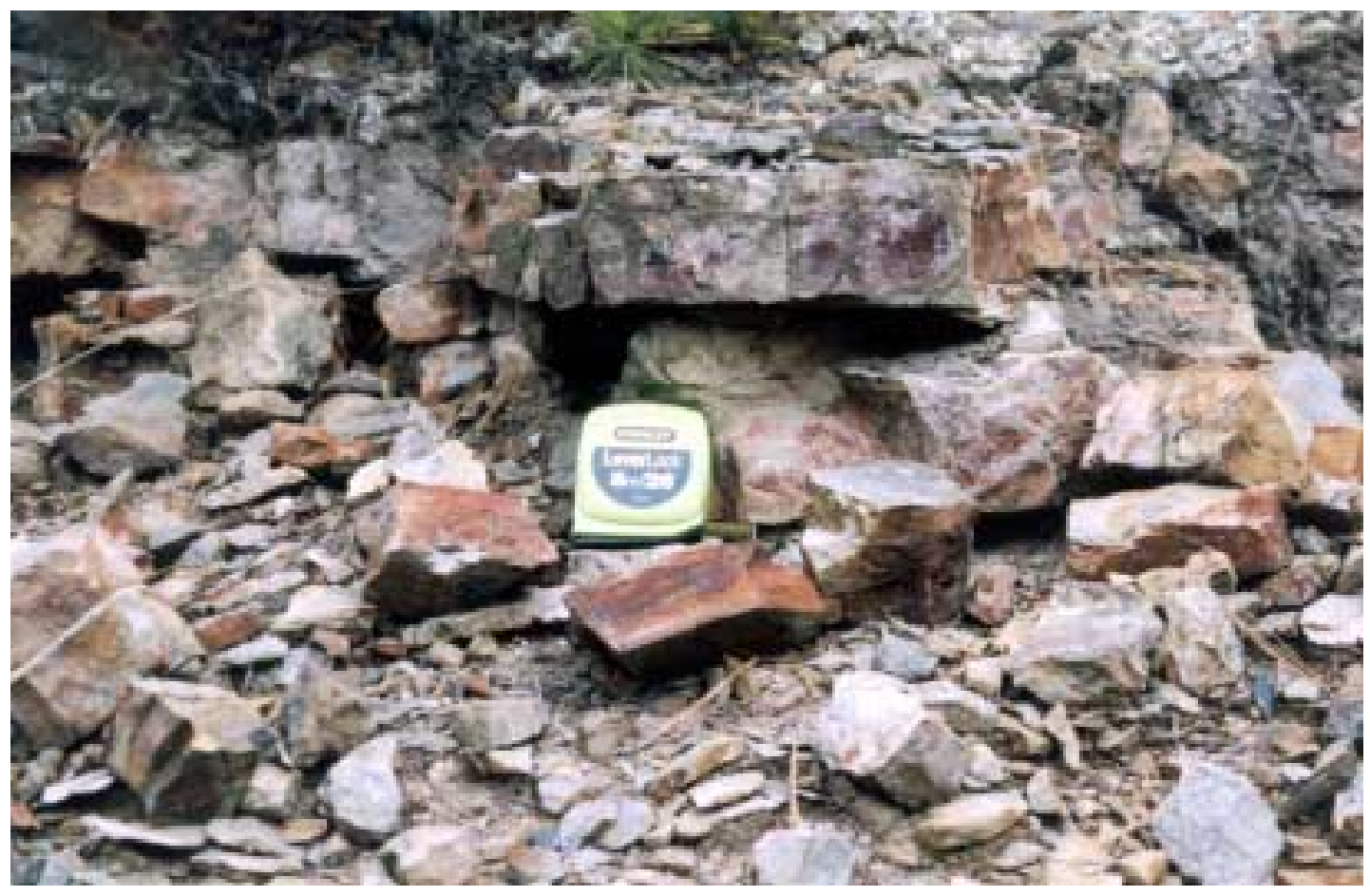

B.

Figure 26: Unit 37, outcrop 5- Crevasse-splay. B. is a close-up view of A. 
The red-color of this unit is most likely a result of result of chemical weathering processes, as indicated by the red residue on the fractured surfaces, and the preservation of sedimentary structures such as trace fossils and bedding.

Crevasse-splays are the result of both major floods on the upper-delta-plain and longer-term channel migration, avulsion, and incision. Crevasse-splay facies occur when water and sediment accrete onto the floodplain through breaks in the channel levee during times of major floods. Often times they consist of sandy and silty sediment dominated by ripple cross-lamination and small-scale cross-bedding. As the floodwaters breach the levee, turbulence and energy of the system diminishes, allowing the suspended sediment to settle out, thus creating a fining-upward sequence (Figure 27; Miall, 1992; Collinson, 1996).

Within the Sherwood Lake outcrops, unit 36 of outcrop 5, which interrupts coal deposition, is the most prominent crevasse-splay deposit. Although the small sandstone beds within outcrops 1,2, and 3 can be interpreted as crevasse-splay deposits as well (Figure 27b), they are much smaller in scale and are more indicative of the interdistributary bay facies, and therefore are included with the bay-sand facies samples. In all cases however, the sandstone deposits interrupt quiet water deposition.

\section{Interdistributary Swamp}

A paludal facies is present only at outcrop 5, and it consists of beds of coal in unit 35. Thickness ranges from $40-80 \mathrm{~cm}$. Coals present in the Price Formation tend to be of extremely poor quality, yielding fixed carbon contents usually lower than $50 \%$ and ash 


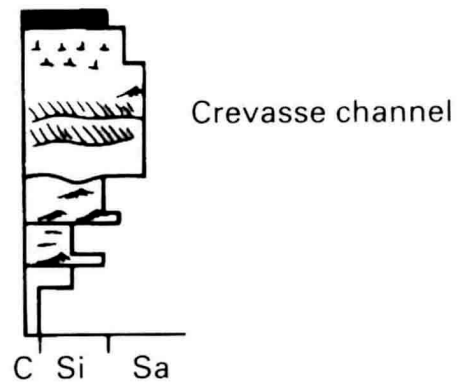

(a)

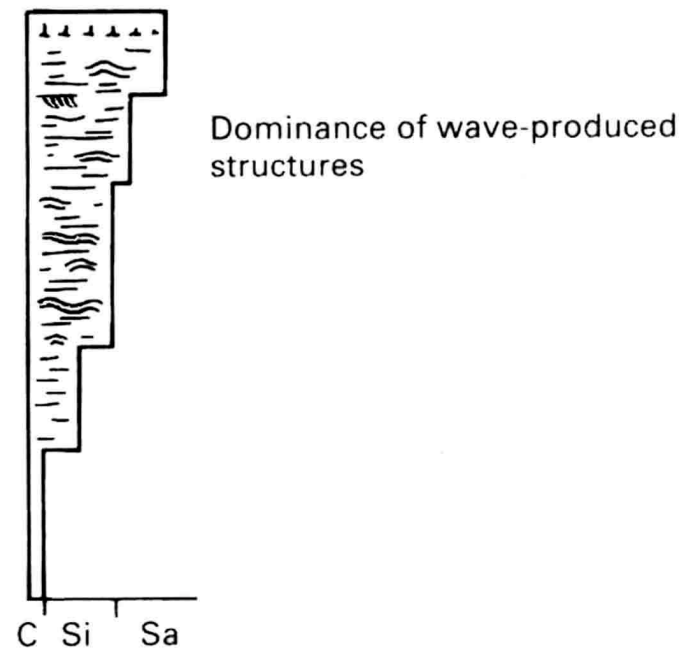

(b)

$$
\begin{aligned}
& \text { Key } \\
& \text { Trough cross beds } \\
& \text { Symmetrical ripples } \\
& \text { Accretion surfaces } \\
& \text { Cootlets } \\
& \text { Carbonaceous }
\end{aligned}
$$

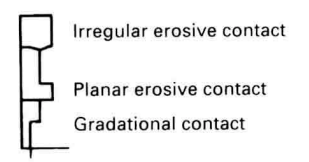

$$
\begin{aligned}
& \text { C-Clay } \\
& \text { Si-Silt } \\
& \text { S-Sand } \\
& \text { Vertical scale: } \\
& \text { (a)-(h) }-2-10 \mathrm{~m} \\
& \text { (i)-(j) }-6-14 \mathrm{~m}
\end{aligned}
$$

Figure 27: Types of crevasse-splay deposits found at Sherwood Lake. (a) An example of a crevasse-splay deposit where the crevasse-splay created a scoured basal contact and a fining upward sequence. (b) An example of a crevasse-splay deposit in which the splay interrupts a bay or bay-mouth facies (Reading and Collinson, 1996). 
contents of $85-90 \%$ (Bjerstedt, 1986). The coal at Sherwood Lake however yields an ash content of 39\%. Bedding is usually crumbly and blocky with yellow and orangered films on individual bedding planes (Figure 28). Siderite nodules are also common within the facies. Thin coal deposits that occur as elongate strips parallel to the channel trend form in floodplains that are predominantly submerged or in backswamp areas lateral to the channel. Vegetation in poorly drained soils and mires leads to the accumulation of peat. Where peat accumulation is below flood level, terrigenous material is included in the accumulation, yielding coal layers with a high-ash content. Where avulsion terminates peat growth, crevasse-splay deposits directly overly the coal. Peat growth is often terminated by erosion of the channel due to channel migration, but the tough, elastic peat generally restricts the depth of erosion (Figure 21b). If eroded, coal may occur as slabs and clasts within the overlying channel sandstone (Coleman and Prior, 1982; Collinson, 1996; Reading and Collinson, 1996).

\section{Interdistributary Bay Facies}

Interdistributary deposits for this study are categorized into two subfacies, bay-fill mud and bay-fill sand. Most interdistributary bay-mud at Sherwood Lake is present at exposures 1,2, and 3 (Figure 29). Thicknesses within the facies vary, but generally tend to be between $2.5 \mathrm{~m}$ and $4 \mathrm{~m}$ of siltstone and mudstone. Bedding ranges from lamination to medium bedding. Few sedimentary structures are seen within the facies, but where present they consist of horizontal bedding and wavy contacts. Bjerstedt (1986) also noted that these units are generally thoroughly bioturbated where the lamination and horizontal 


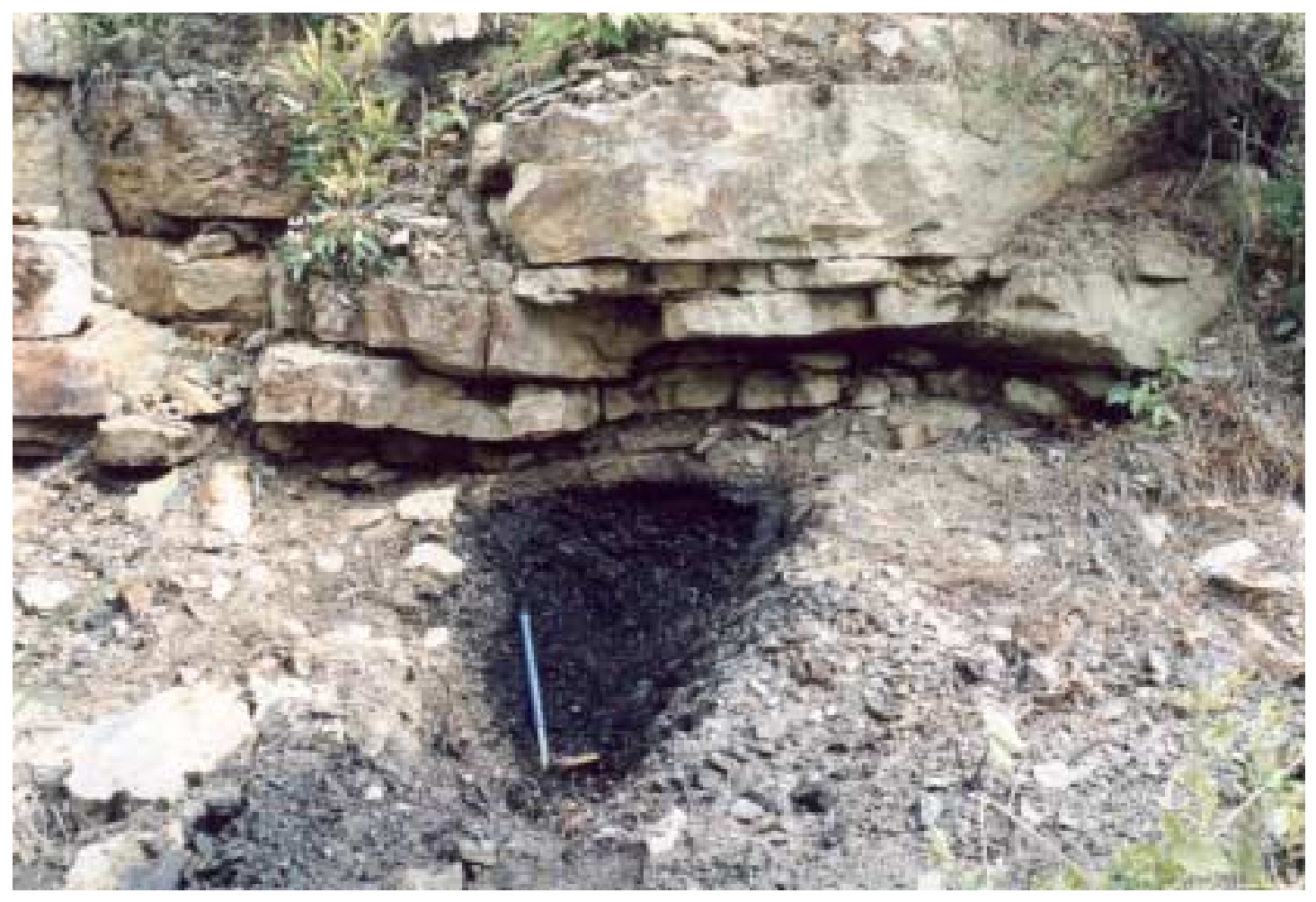

Figure 28: Coal deposit located at the base of outcrop 5. 


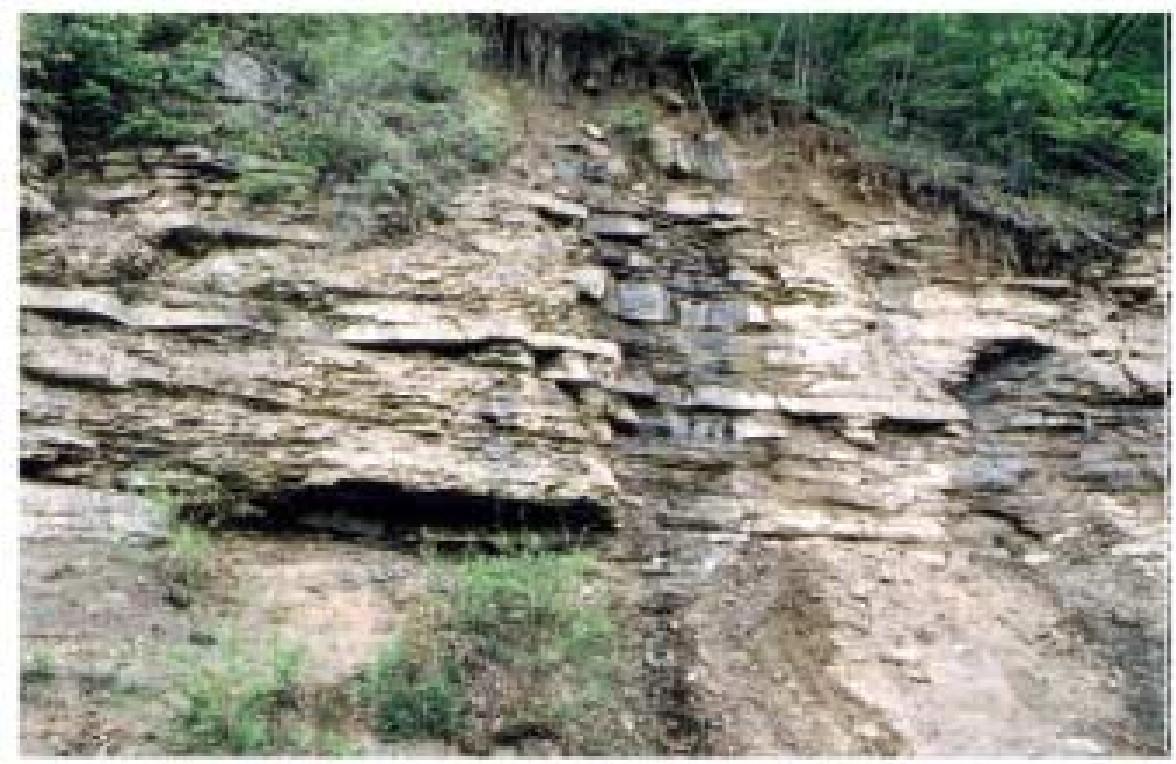

A.

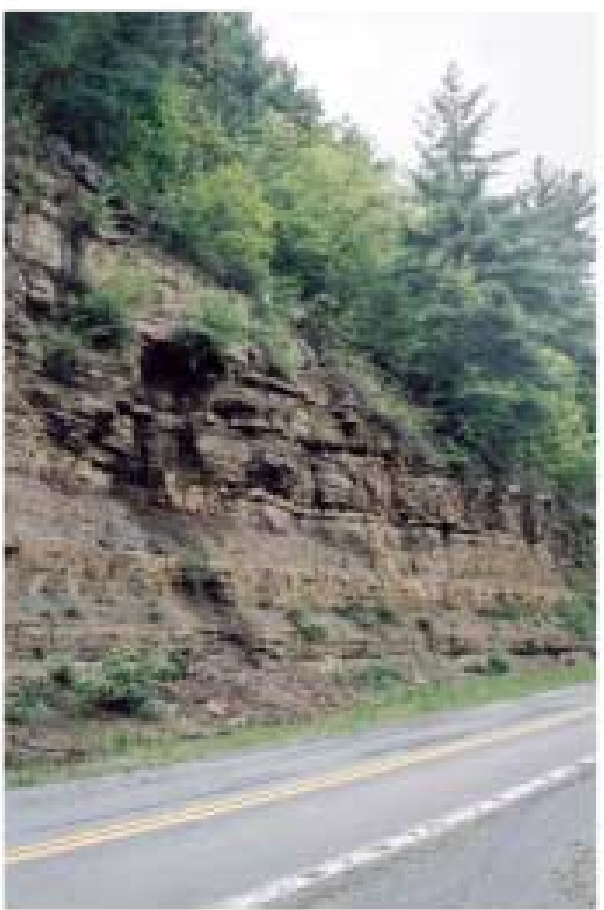

B.

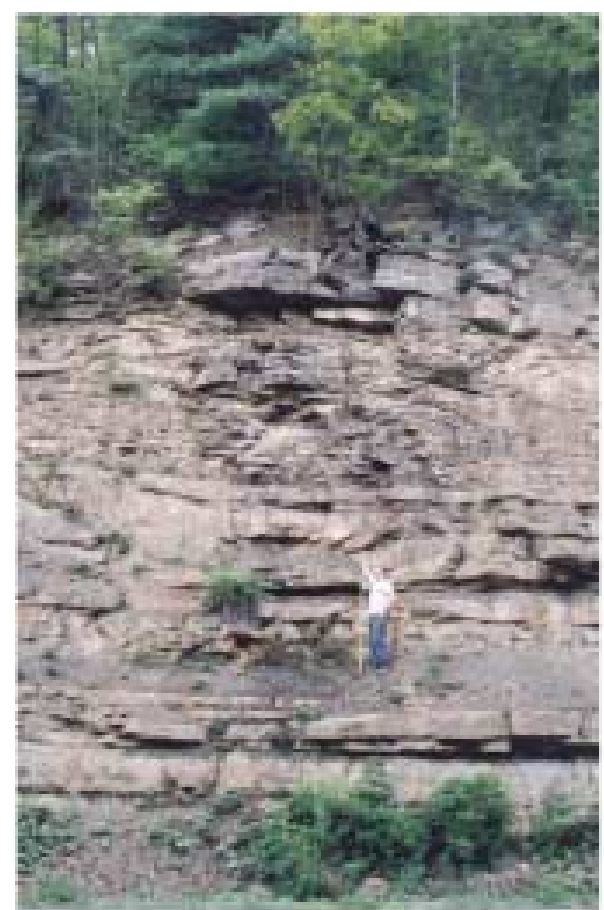

C.

Figure 29: Interdistributary bay facies. A. Outcrop 1. B and C: Outcrop 2. 
bedding is absent. Units 11-15 (outcrop 2) and 19 (outcrop 2) represent the interdistributary bay-mud deposits.

Bay-sand facies are also present at outcrops 1,2, and 3 occurring as very-fine to medium-grained sandstone beds (Figure 29). In a few cases the average grain size ranges from coarse sand to pebbles. Although the thickness of the individual beds within the facies varies between outcrops, the sandstones tend to be about $20-60 \mathrm{~cm}$ thick. Generally the interdistributary bay-sands are interbedded with shale and mudstone, and often times beds are either discontinuous and lensoid in shape or preserve the form of a small channel. Frequently the sandstones have small-scale planar cross-beds and erosional basal contacts. Units 10, 16, 17, 18 represent bay-sand facies.

Interdistributary bays are shallow bodies of water that are partially open to the sea or at least connected to it by small tidal channels. Commonly, these bays are elongate and contain brackish or marine waters; they can in many instances be surrounded by marshes or distributary channels (Coleman and Prior, 1982). Most frequently, deposition in the bays occurs where fine-grained sediment settles out of suspension due to lack of wave activity. Lenticular bedding is the most common type of bedding and is a result of localized wave activity, but parallel bedding is also common. Scour structures and current ripples are present, generally produced by tidal currents or river-flood currents (Reineck and Singh, 1980).

Bay-fill deposits form initially where breaks occur in the major distributary channels during flood stages. Gradually flow increases through successive floods, reaching a peak of maximum deposition, waning, and then becoming inactive. As a result of inactivity, the bay-fill deposits can be inundated by marine waters, and therefore 
may revert to a bay environment. Individual-bay fill deposits are generally thin beds of sandstone and siltstone by themselves, but continuing subsidence and the repetition of similar processes result in stacking of one bay fill on top of another. The stacking pattern of bay-fill deposits tends to be irregular, meaning that some cycles are thicker than others or of different character, but in general there is an overall increase in the proportion of nonmarine facies upward (Bhattacharya and Walker, 1992). The ideal shallowingupward facies succession of the bay-fill is illustrated by Figure 30. Typically these deposits begin with brackish-water clay and organic debris and are often topped by wellsorted distributary sand. Also typical of the bay-fill sequence is irregularity of the beds (Coleman and Prior, 1982; Bhattacharya and Walker, 1992). The bay-fill deposits at Sherwood Lake (units 11-19) display the features described by Coleman and Prior (1982) and Bhattacharya and Walker (1992), where the most characteristic features are the irregularity in stacking pattern and a shallowing-upward sequence.

\section{Delta Front}

The delta front is the zone of interaction between fluvial and basinal processes, and as a result it is the site of much active deposition (Bhattacharya and Walker, 1992). At the mouths of distributaries, the flow of the river water expands both vertically and laterally, which decreases the flow competence and deposits sediments. In deltas where the basinal processes are weak, fluvial processes predominate and coarse-grained deposits such as distributary mouth bars are formed (Orton and Reading, 1993). Where wave processes are the most significant, swash bars, beach ridges, and beach spits 


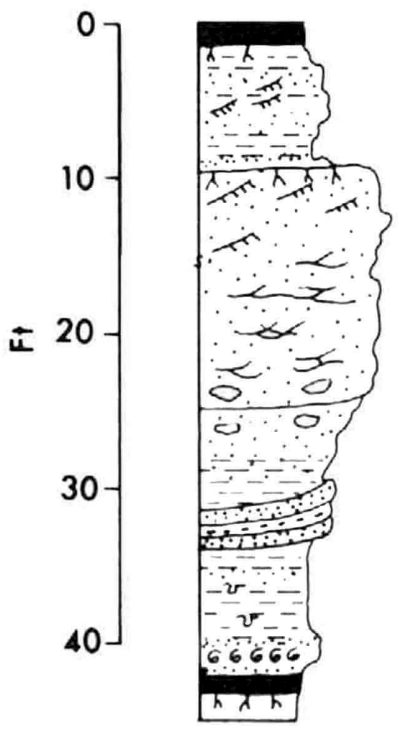

Pt.

$\mathrm{Cl}$, burrowed, $\mathrm{FeCO}_{3}$, nod., Pyrite

Cl.st. stringers, climbing ripples

Sd., climbing ripples, burrowed at top sd.

Sd. $w /$ st. stringers, sd. layers sharp base, sm. x.lam.

St. w/sd. stringers, lenticular lam. current ripples

Alt. st.-cl. stringers, scat. burrows

$\mathrm{Cl}$., burrowed, scat. sh., st. stringers

Sh., st., sd., burrowed

Pt.

Figure 30: Stratigraphic column of typical bay-fill succession (Coleman and Prior, 1982). 
develop around the distributary mouths. And finally, where tidal processes dominate, tidal channels with tidal sandflats and ebb - and flood - tidal deltas develop (Reading and Collinson, 1996).

\section{Beach-Bar Facies}

Rocks that were deposited in a beach-bar environment are present at outcrop 4 (units 24, 25, 26 and 27; Figure 10A) in the Sherwood Lake section. Units 26 and 27 expose a 7 meter section of fine- to coarse-grained sandstone. Large-scale planar crossbeds with many reactivation surfaces occur low in the unit. Also present is flaser bedding which occurs as mud drapes in troughs of rippled bedforms Rip-up clasts from the mud drapes have become incorporated into the sandstone. The coarsening-upward sequence of the lower section of the facies is topped by a fining-upward sequence of medium to finegrained sandstone. The upper part of the section has considerably less shale than the lower unit with fewer shale partings and clasts. It also is almost entirely medium bedded with small-scale planar cross-bed sets.

Units 24 and 25 expose over 2 meters of a transgressive-conglomeratic lag deposit. Pebble-sized grains of siderite, quartz, and rock fragments (primarily sedimentary), as well as broken fossil material are very abundant (Figure 31). Sorting low in the units is poor, with grains ranging from pebble size (largest grain $9 \mathrm{~cm}$ ) to very fine within the matrix. Matrix within the units has a reddish brown color, indicating oxidation of iron-bearing minerals. This trangressive unit 24 corresponds to T4 (the fourth transgressive facies during Price deposition) as discussed by Kammer and Bjerstedt (1988) (Figure 32). The T4 transgression is defined by fossiliferous lags 


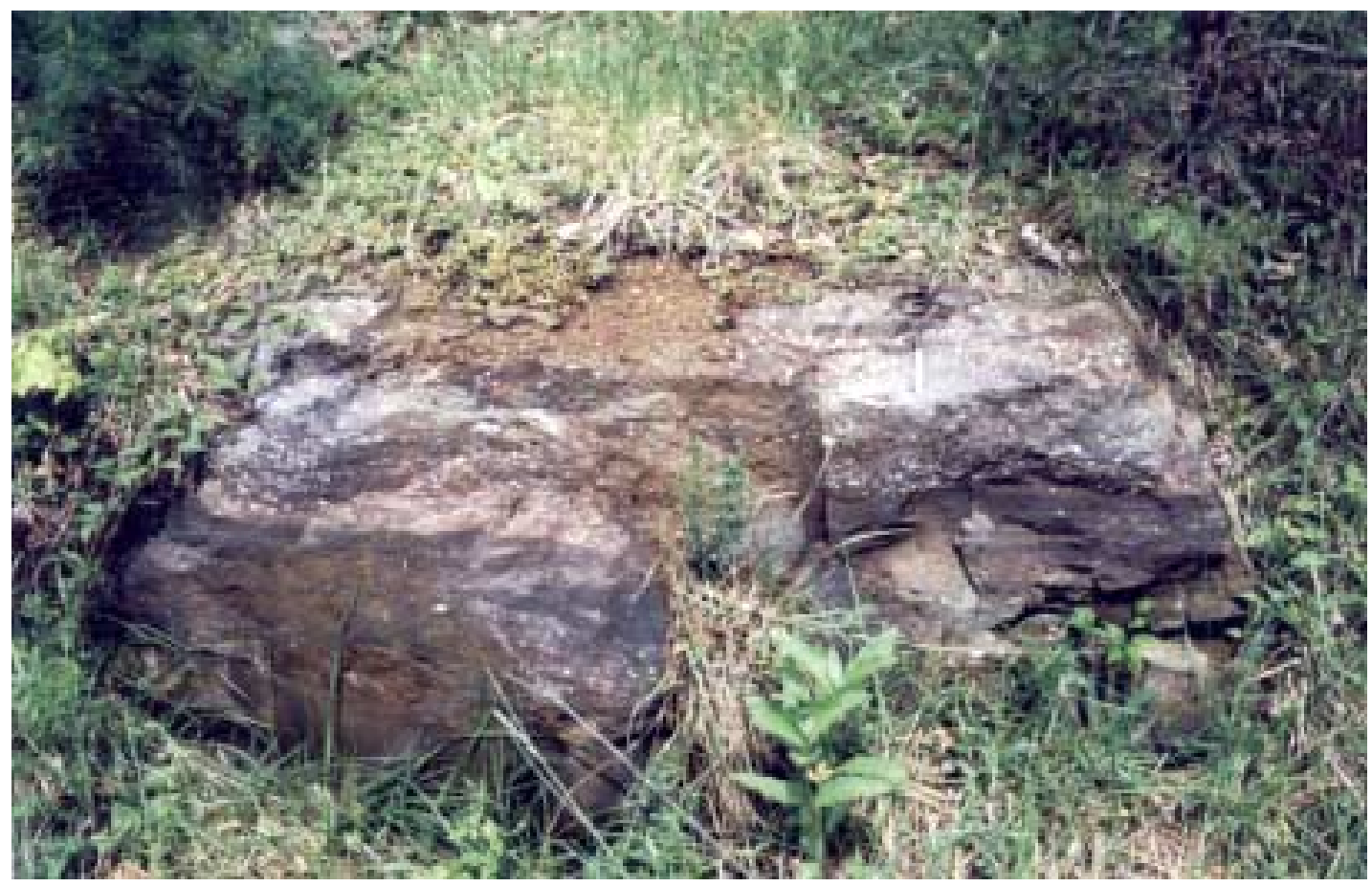

A.

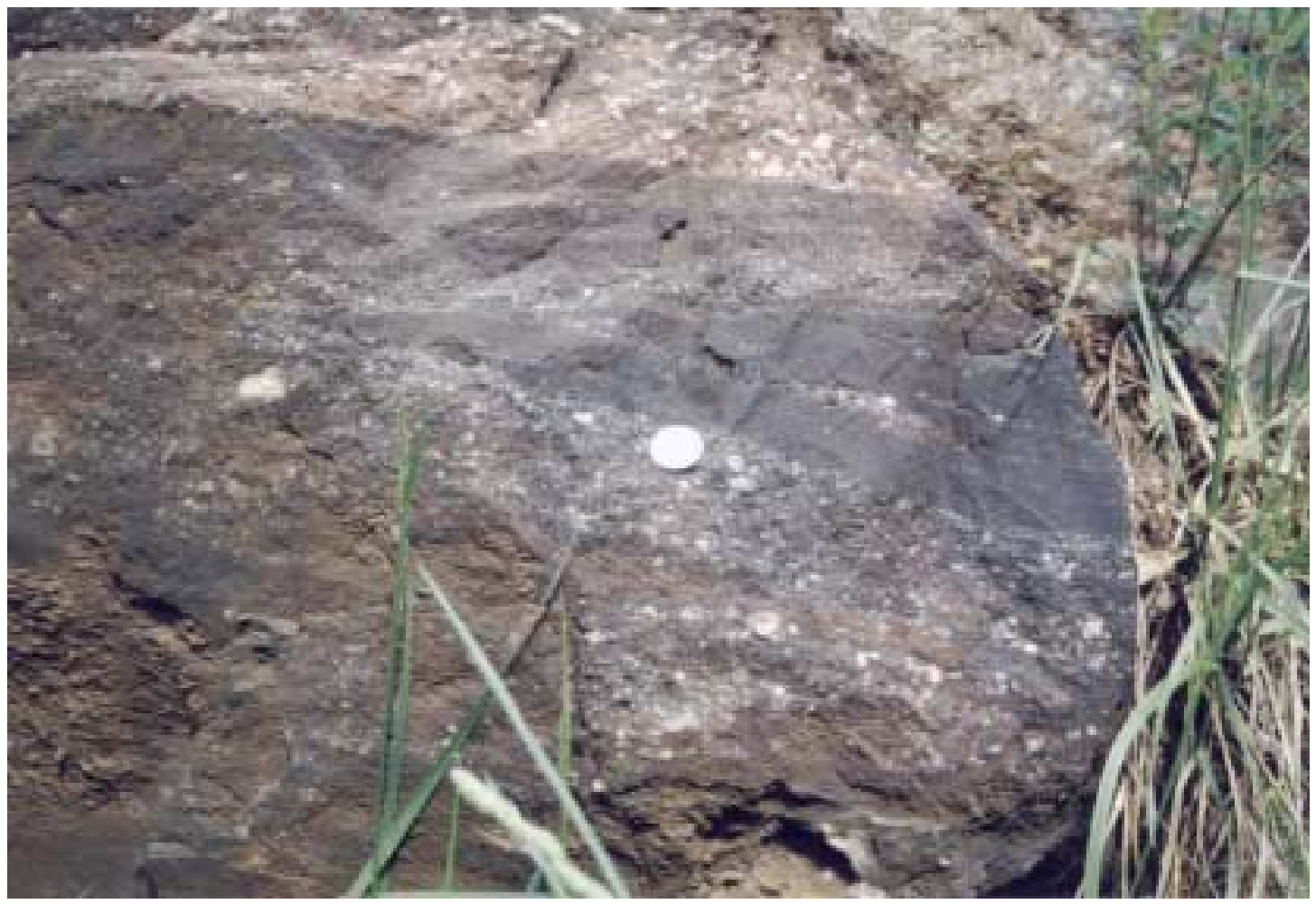

B.

Figure 31: Unit 24- Transgressive lag deposit. Unit consists of broken fossil material, large quartz pebbles and siderite nodules. This unit is indicative of the fourth trangressive facies during Price deposition, T-4, as noted by Bjerstedt and Kammer, 1988. 


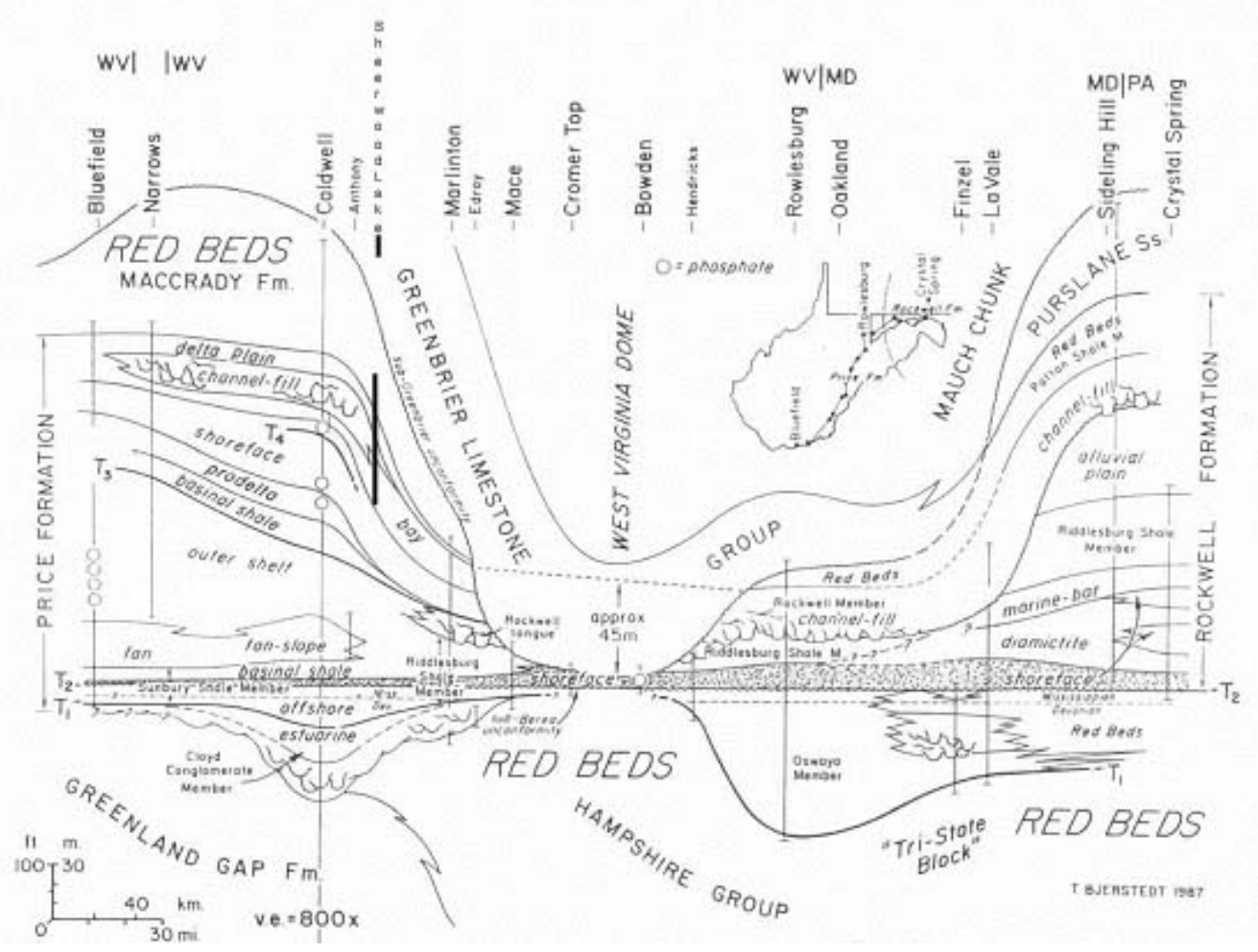

Figure 32: Stratigraphic cross-section of the Price Formation from Bluefield, WV to Crystal Spring, PA. Transgressive beds are labled as T1-T4, where T4 is the transgressive bed recognized at Sherwood Lake (Bjerstedt and Kammer, 1988). 
containing phosphatic pebbles and a limonitic matrix. The fossils present in the lags represent pavements of shell debris that accumulated on the shoreface. Unit 25 is a clean, well-sorted, medium-grained sandstone that represents the swash zone.

Beach-bar deposits are a common geomorphic landform found within the delta front. Beach-bar deposits form within the foreshore and shoreface and are affected by a number of wave and tide processes. Deposition on the shoreface usually occurs as longshore bars and troughs. Sediment transport is dominated by bi-directional, oscillatory motion related to primary incident waves, plunging breakers and longshore currents. (Reineck and Singh, 1980; Coleman and Prior, 1982). The dominant sediment withinthe facies ranges from fine sand to gravel, but muds and silts may also be deposited when marine processes are quiet (Boggs, 1995). During strong waves, undulating wave and current ripples, hummocky cross-stratification, and dunes form. As these structures migrate, small to large-scale cross-beds are produced (Coleman and Prior, 1982).

The foreshore, is dominated by wave swash. Wave swash produces small to medium-scale bedsets of evenly laminated sand (Reineck and Singh, 1980). Commonly, the stratification occurs in wedge-shaped sets, bounded by low-angle surfaces of truncation (Coleman and Prior, 1982). Swash stratification is often times marked by variations in grain sizes of sand, and also by concentration of heavy minerals (Boggs, 1995).

The classic prograding beach-bar sequence can be seen in Figure 33. In this sequence the succession begins with the off-shore facies of bioturbated mudstone and siltstone with thin storm-generated interbeds of sand. Overlying this are the shoreface and foreshore facies. The shoreface is dominated by hummocky cross-stratification, 


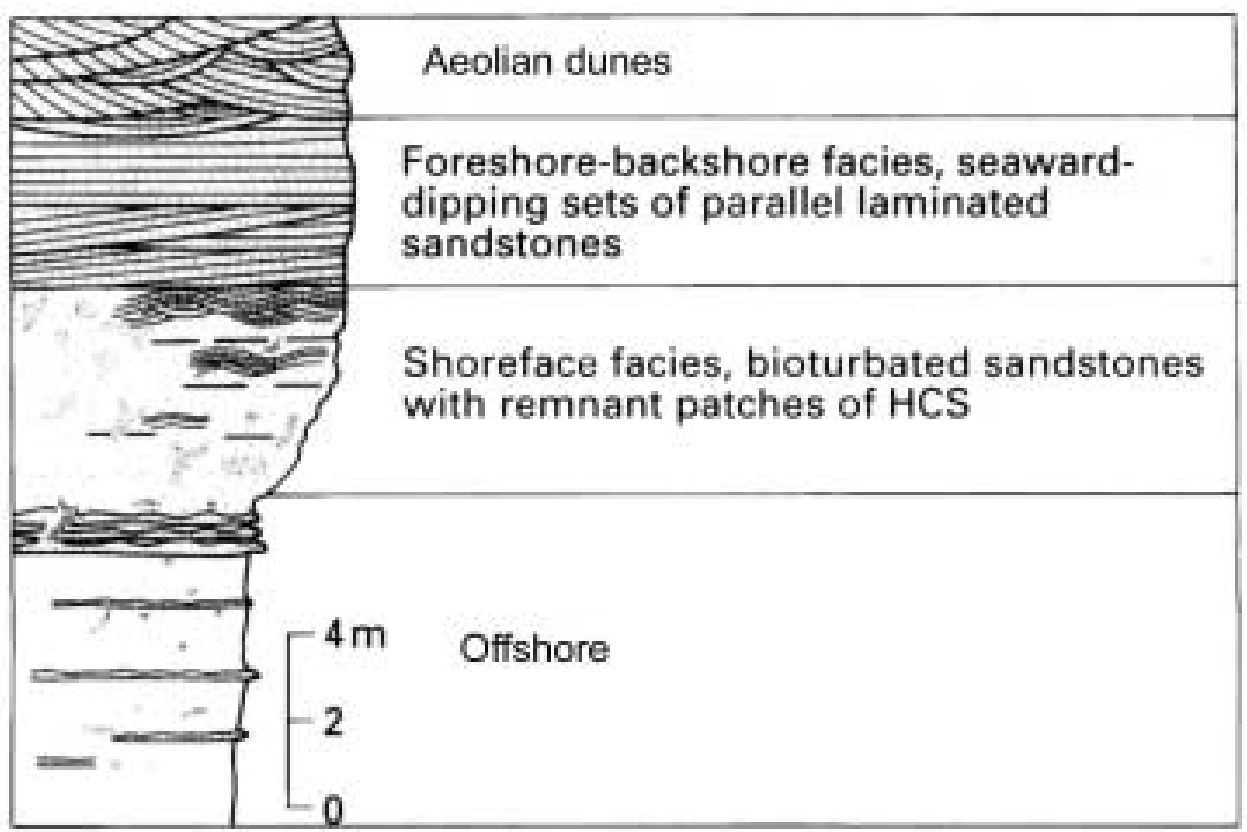

Figure 33: Typical prograding coarsening-upward shoreline sequence from offshore facies up to aeolian dune facies (Reading and Collinson, 1996). Present at Sherwood Lake are the shoreface and foreshore facies. 
when not heavily bioturbated, whereas the foreshore is characterized by parallel laminated sandstone. Capping off the ideal succession, may be the aeolian-dune facies where large-scale sets of cross-beds are present.

When compared with the ideal beach-bar sequence, the beach-bar section at Sherwood Lake comprises only the shoreface and the foreshore facies. The shoreface facies is represented by unit 26 which is a fine to medium-grained sandstone with common shale partings and scoured surfaces (Figure 34). Also present within the unit are large-scale planar cross-bed sets that fine up to small-scale planar cross-beds. The foreshore deposits are represented by unit 27 , which and consists of a coarse to finegrainedsandstone, with considerably less cross-bedding than the underlying unit. Parallel lamination occurs in the upper portions of the unit (Figure 35).

\section{Lagoon}

Units 28-31 of outcrop 4 (Figure 10B) represent rocks that were deposited in a lagoonal setting, where unit 28 represents the subtidal lagoon and units 29-31 represent the washover sandstones. These units are $6 \mathrm{~m}$ of coarsening-upward silty shale and interbedded fine-grained sandstone, which contain small rip-up clasts of shale. Bedding within the facies is laminated to thin but often times can appears massive. Starved ripples are present in the lower beds, and wavy bedding in the upper beds, indicating that both the current strength and sand supply increased (Figure 36). Siderite nodules are common throughout, as are pyritized burrows (Bjerstedt, 1986), and shale rip-up clasts. Bjerstedt (1986) observed abundant macerated organic debris and blue-grey carbonaceous films on bedding surfaces. 


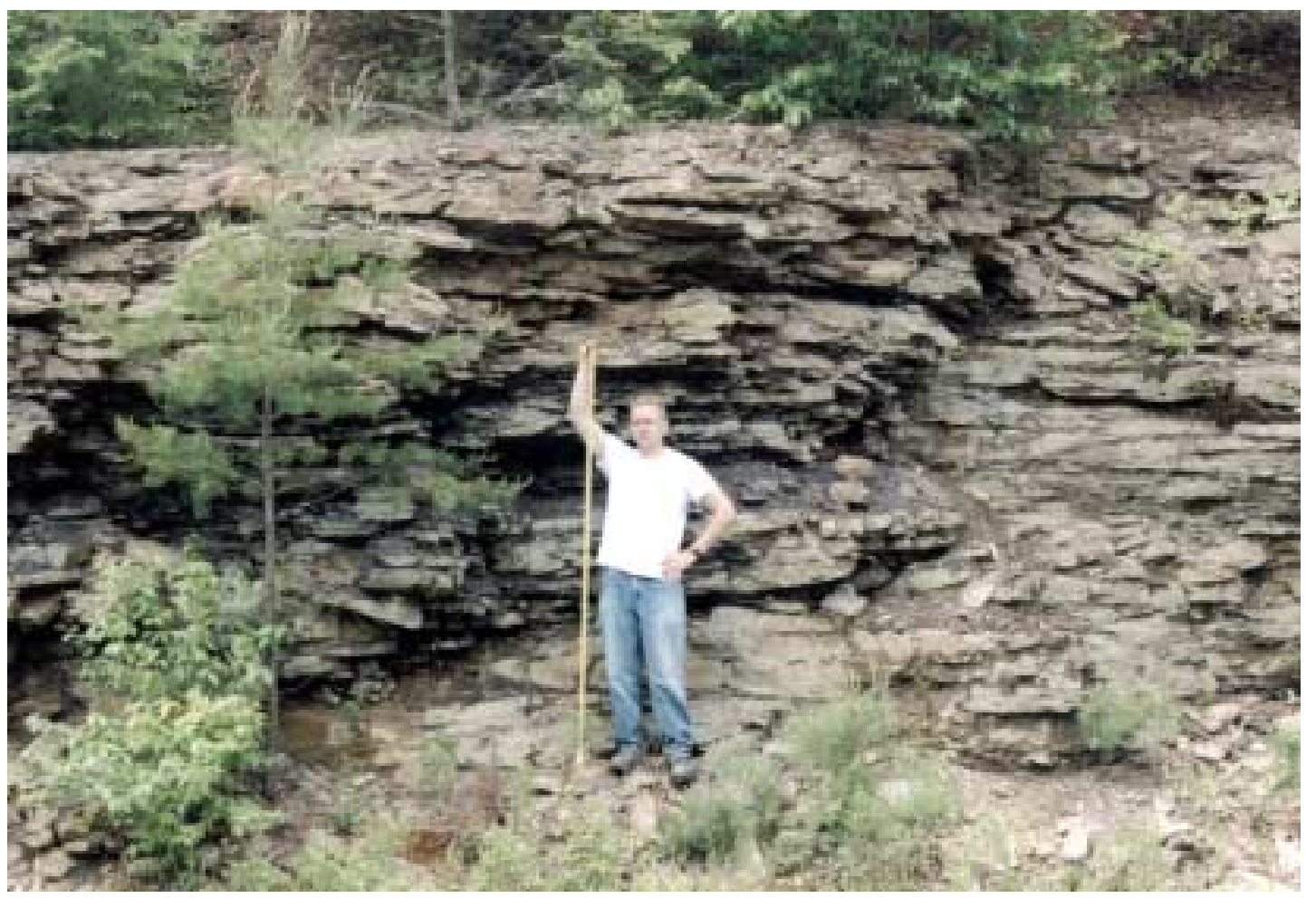

A.

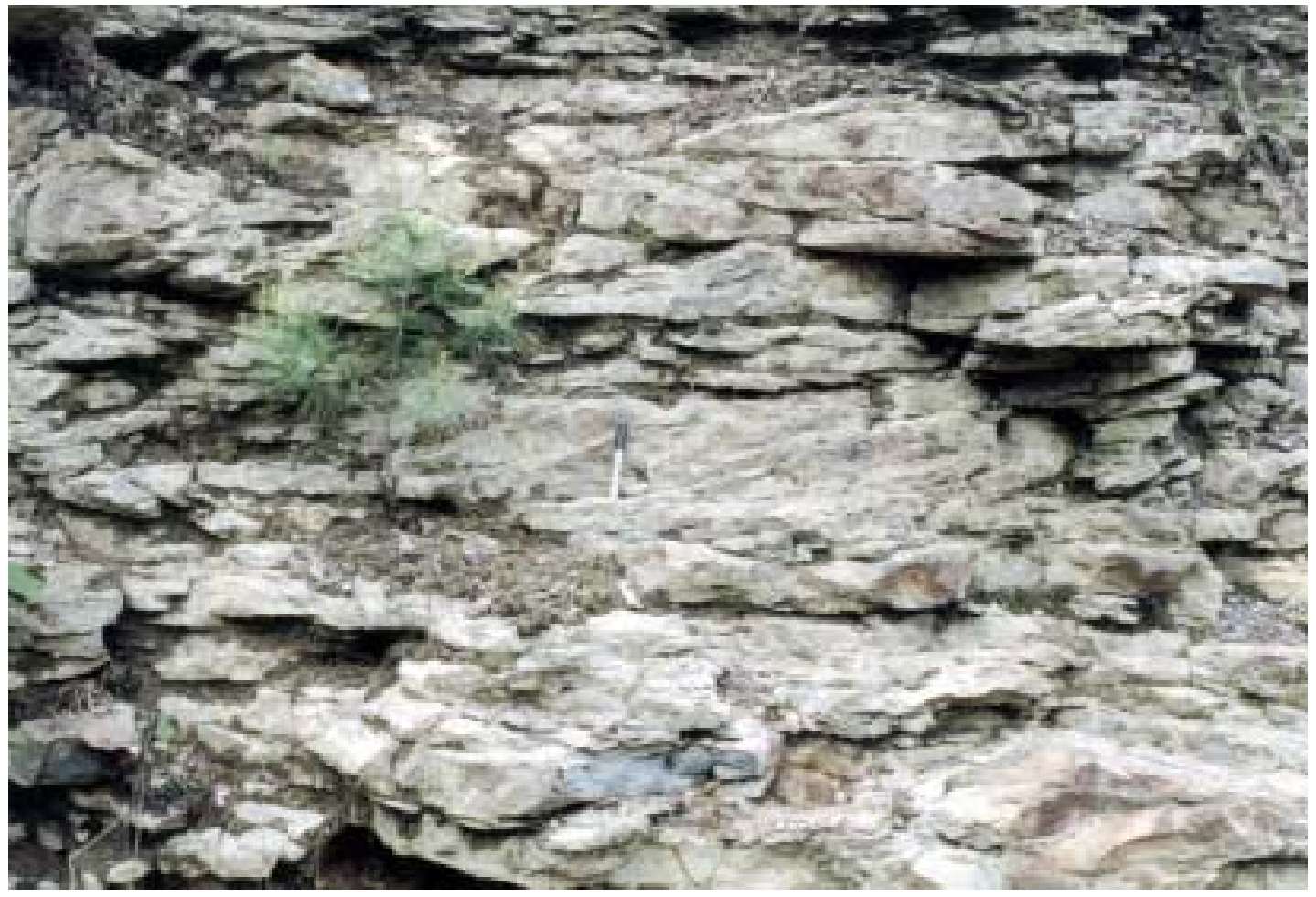

B.

Figure 34: Unit 26- Beach-bar facies, where B. is a close-up view of A. Note large-scale cross-beds and shale partings throughout the unit. 


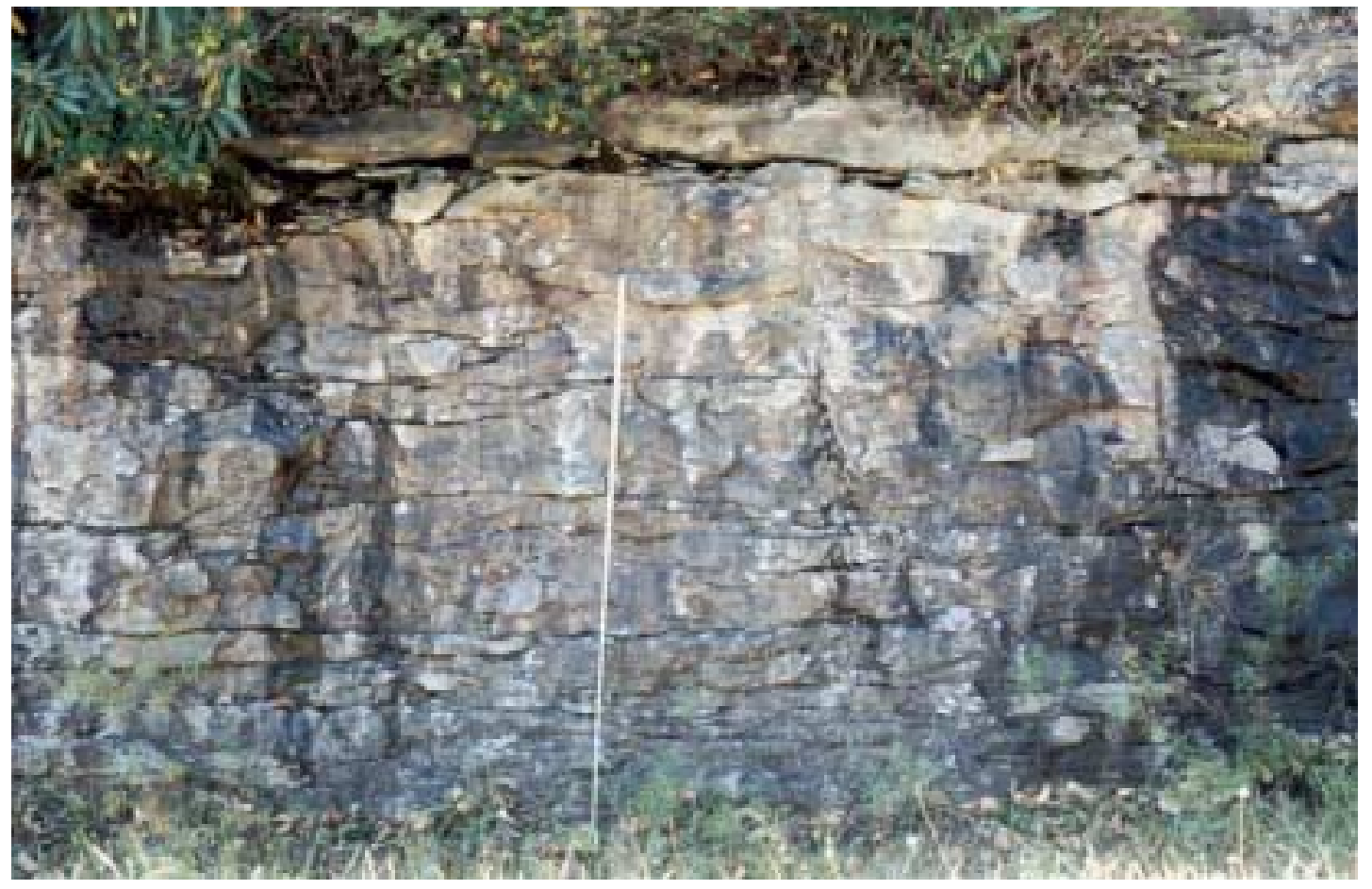

Figure 35: Unit 27 representing the foreshore of the beach-bar facies. 


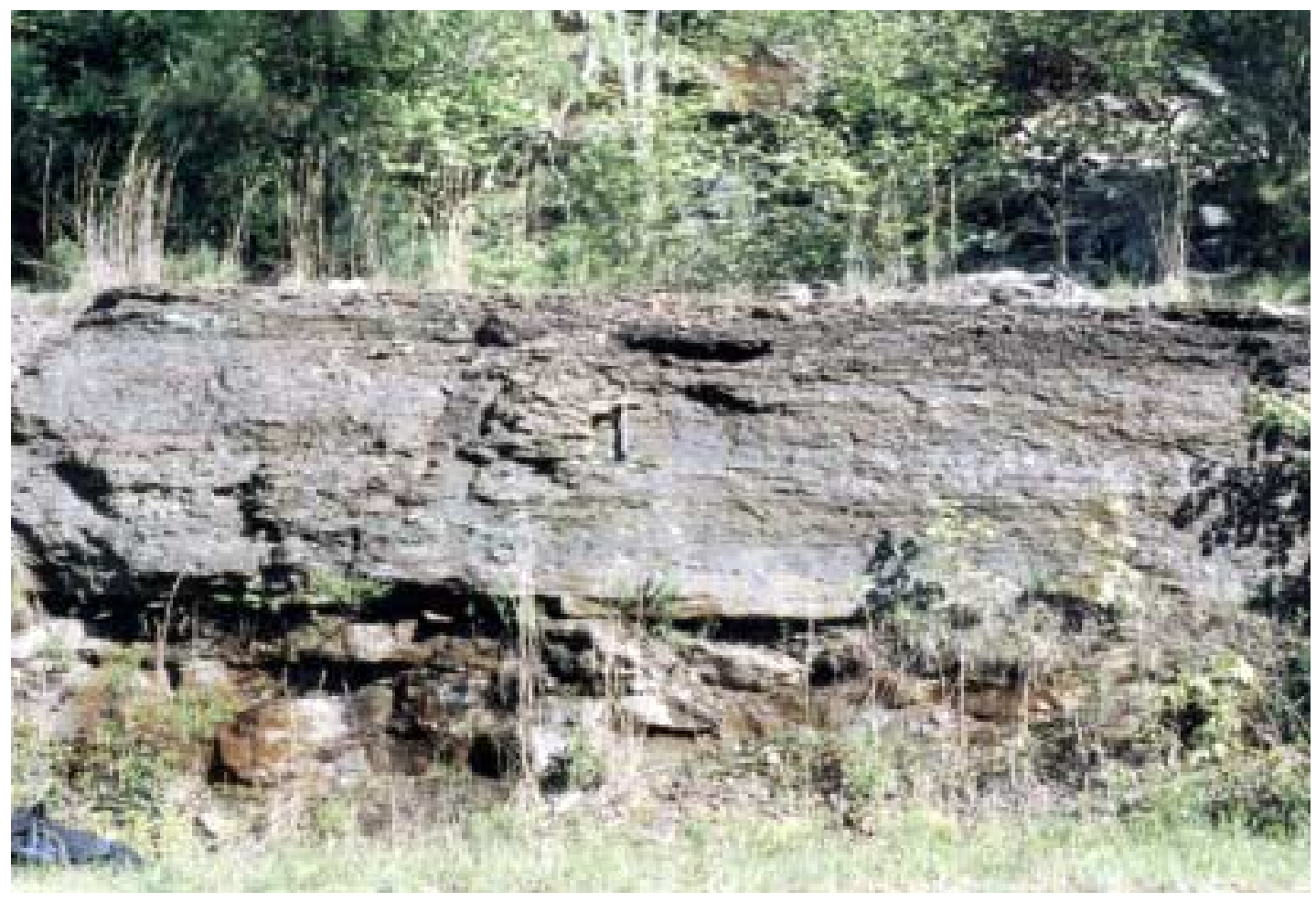

A.

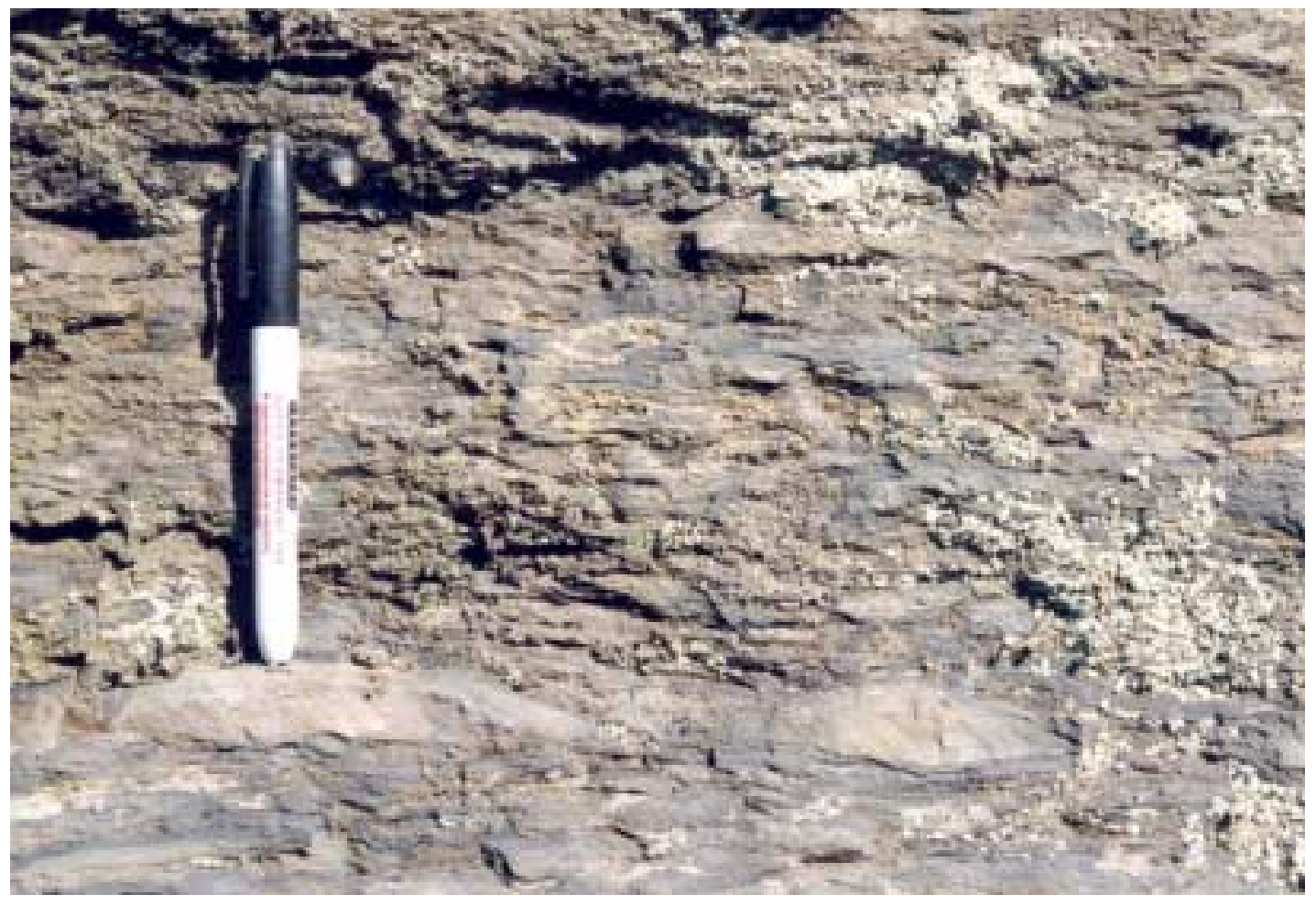

B.

Figure 36: Lagoonal facies. B. is a close-up view of A. and shows starved ripples and small sandstone lenses. 
Lagoons are areas of shallow water protected from the sea. Water salinity varies greatly within the facies and is dependant on the degree of contact with the sea, the amount of river input, and the tidal range. Often times lagoonal facies consist of interbedded organic-rich mud and sand, where symmetrical ripple forms are common (Reading and Collinson, 1996). A fining-upward sequence is often present (Figure 37) where poorly sorted coarse-grained sandstone with pebbles of peat, woody debris, and terrestrial nodules (siderite, pyrite, etc.) form a basal layer, indicating deposition during high-energy floods. As the energy of the system diminishes, deposition of finer-grained sediments (horizontally laminated or wavy bedded mud and silt) continues until eventually the lagoon is infilled (Reineck and Singh, 1980). Although at first glance clastic lagoonal deposits can look similar to bay-fill muds, the two have distinct differences. First and foremost the lagoonal deposits tend to show a fining-upward sequence, where the bay-fills often show a coarsening-upward sequence. Also, the depositional sequence within an interdistributary bay-fill has more irregularities and inconsistencies in bedding and sedimentary structures, where as lagoonal deposits show a more regular bedding pattern. Stratigraphic positioning can also indicate a lagoonal setting. Frequently lagoonal deposits are located immediately behind the beach-bar, which in a prograding deltaic stratigraphic section will be above the beach-bar deposits (Reineck and Singh, 1980). 


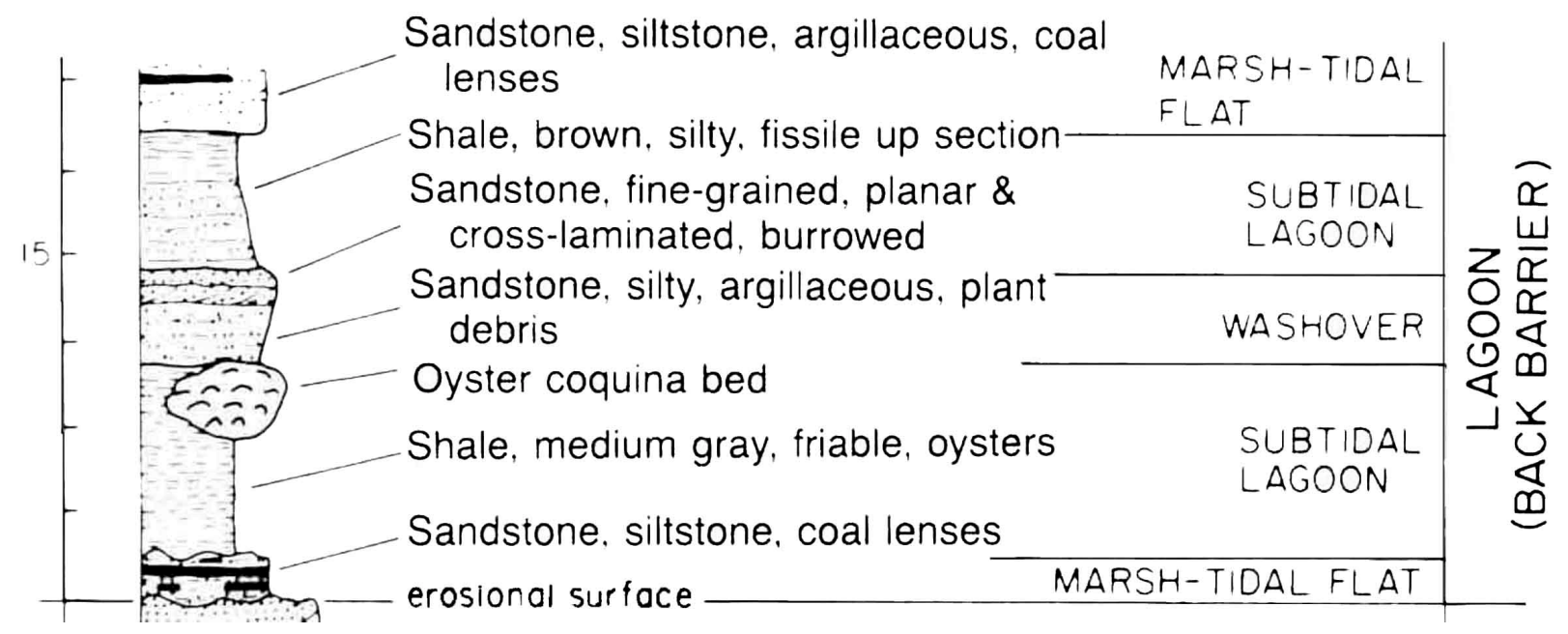

Figure 37: Classic stratigraphic column of a back-barrier/lagoon facies. Not present in the Sherwood Lake outcrops is the oyster coquina bed (Boggs, 1995). 


\section{SEDIMENTARY PETROLOGY}

\section{Petrography}

Based on examination of 57 thin sections, most of the Sherwood Lake sandstones can be classified as sublitharenites, with a few samples being quartzarenites and litharenites (Figure 39, Figures 40-41; Appendix B; Folk, 1968). Of the 22 types of grains identified in these rocks, quartz and lithic fragments dominate the total rock volume. Quartz was subdivided into monocrystaline (normal), undulose (wavy), polycrystalline, and chert grains. Collectively, these grains make up from 33 to $93 \%$ of the total rock volume. Lithic fragments make up $1-26 \%$ of the total rock volume. Lithic fragments consist of both sedimentary rocks and low-grade metamorphic rocks. Sedimentary rocks include erosional clasts of shale and in some instances sandstone, whereas metamorphic rocks include phyllite and schist. Total feldspar percentages (plagioclase and microcline) range from $0-4 \%$, with plagioclase being the more prevalent grain. With only a few exceptions, the primary cement of these sandstones is quartz. Calcite is a secondary cementing agent.

Other detrital minerals present in the sandstones include muscovite, chlorite, tourmaline, zircon, fossil fragments and calcite crystal, which are generally present in very small amounts. Secondary replacement minerals such as pyrite, iron oxidesincluding hematite and limonite, and siderite are common in these sandstones.

\section{Quartz}

Generally, monocrystalline quartz is the most common grain. Of the total rock percentage, it ranges from 9 to $46 \%$, with an average of $32 \%$. Monocrystalline quartz, often called normal quartz, is recognized primarily by its low birefringence, lack of 


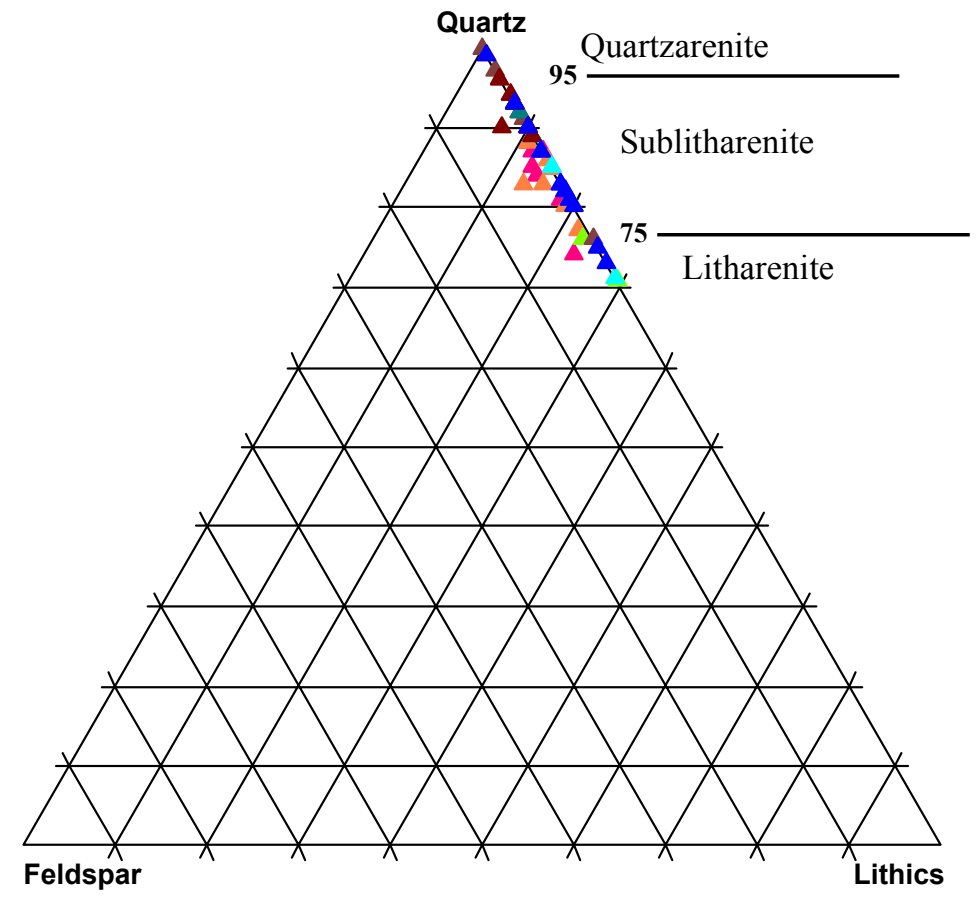

Figure 38: QFL diagram of all 57 samples, color coordinated by facies. Pink- Fluvial; Orange- upper distributary channels; Dark Green- upper crevasse-splay; Light Green- lower distributary channels; Turquoise- Lagoon; Blue- Beach; Dark Brown- Interdistributary bay.

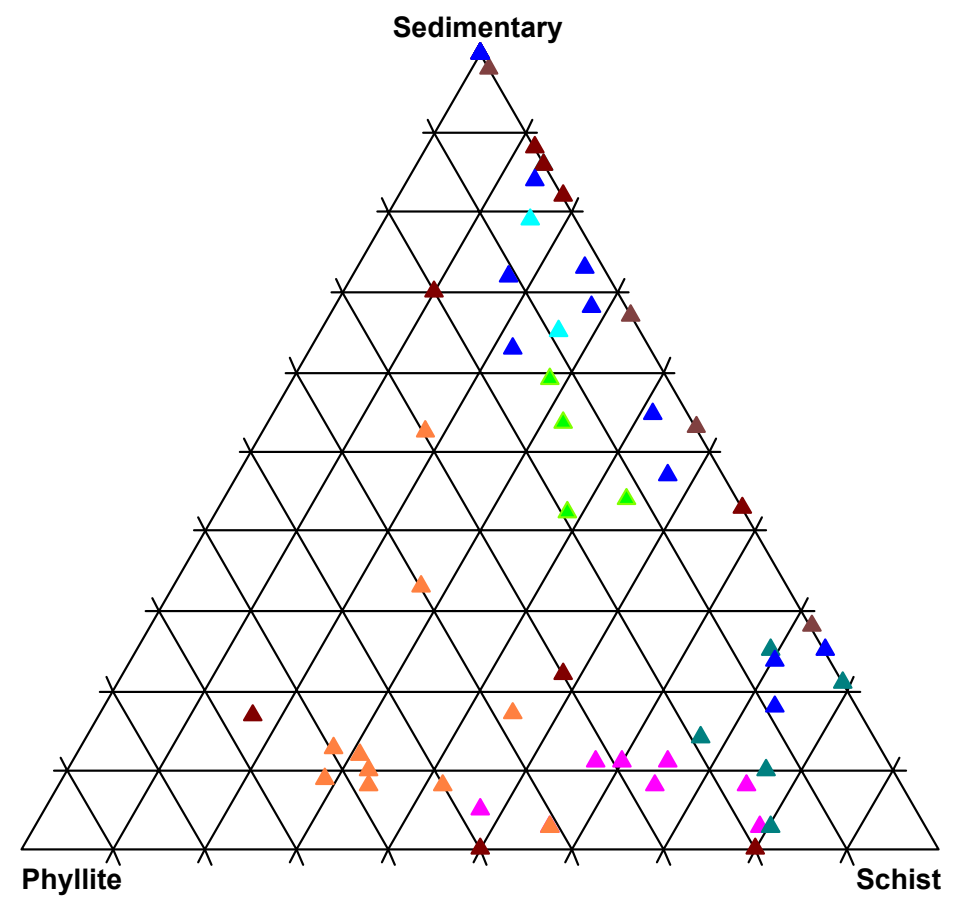

Figure 39: SPS diagram for all facies color coordinated same as above. 


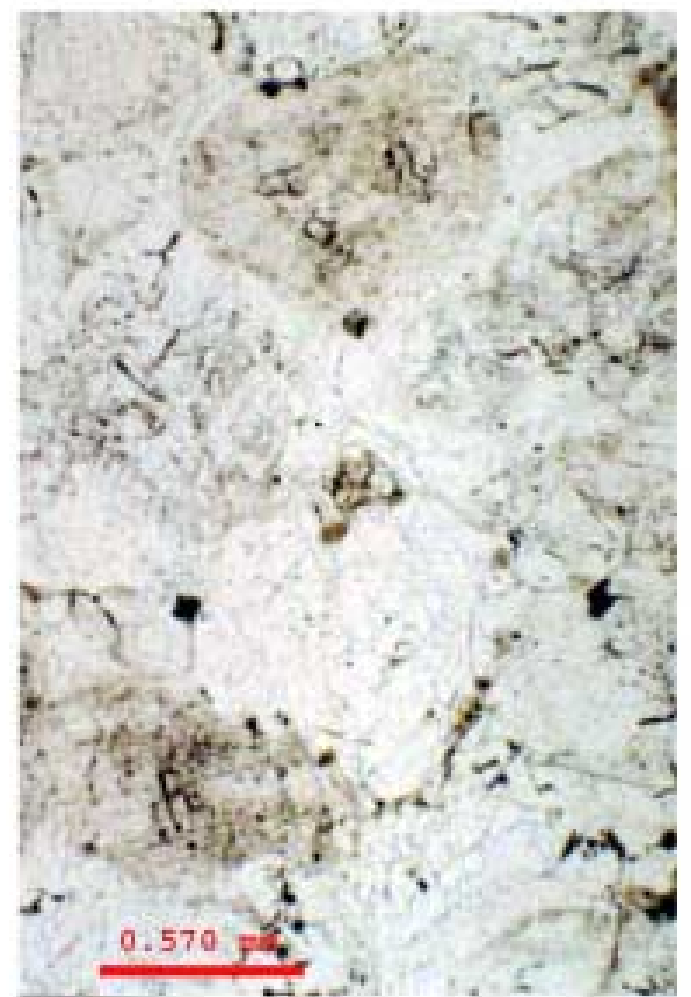

A.

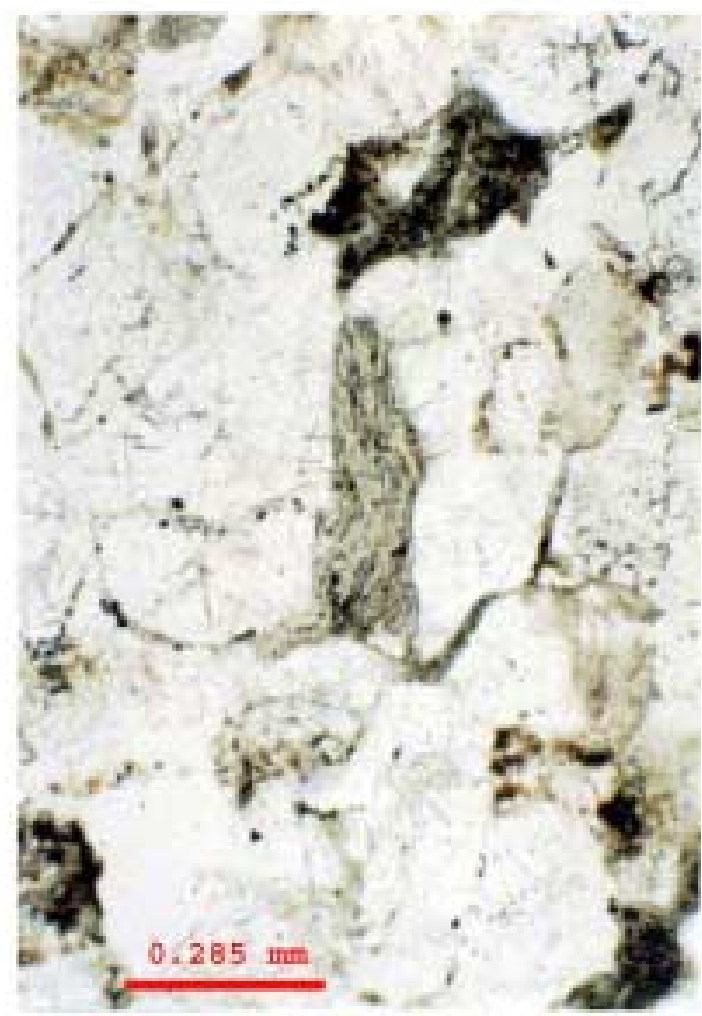

C.

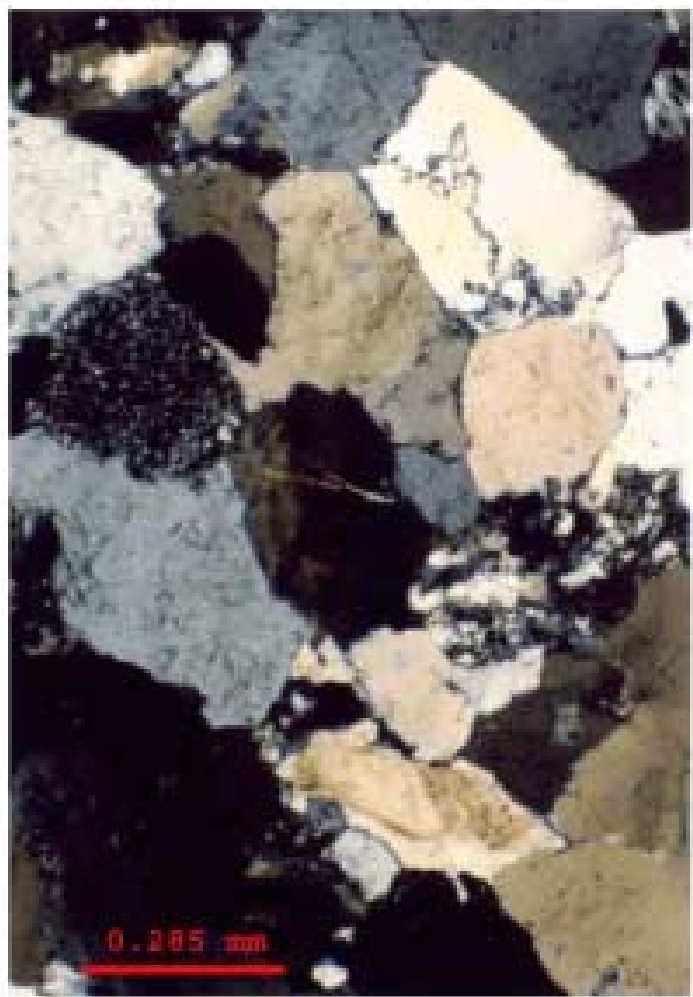

B.

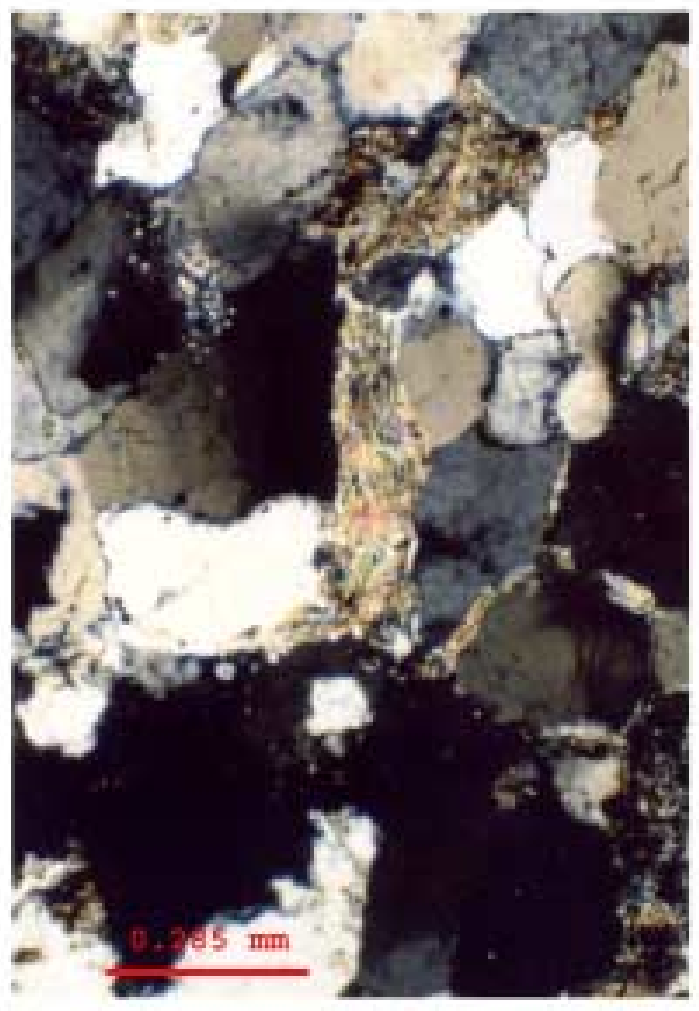

D.

Figure 40: Quartz-rich sample (25-06) in plain light (A) and in crossed nicols (B). Sublitharenite with dominant phyllite and schist grains dominant (sample 39-01) in plain light (A) and in crossed nicols (B) 

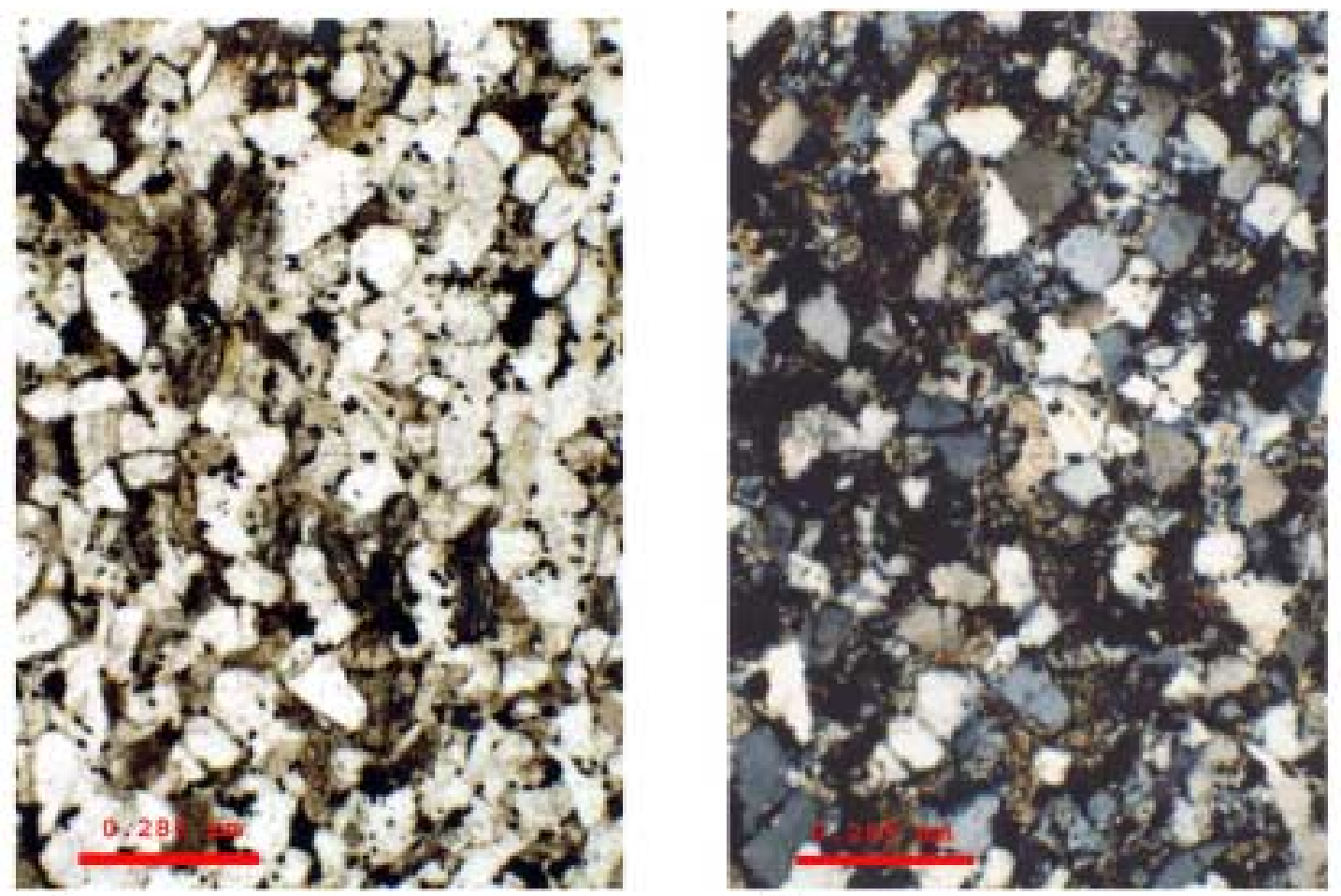

A.

B.

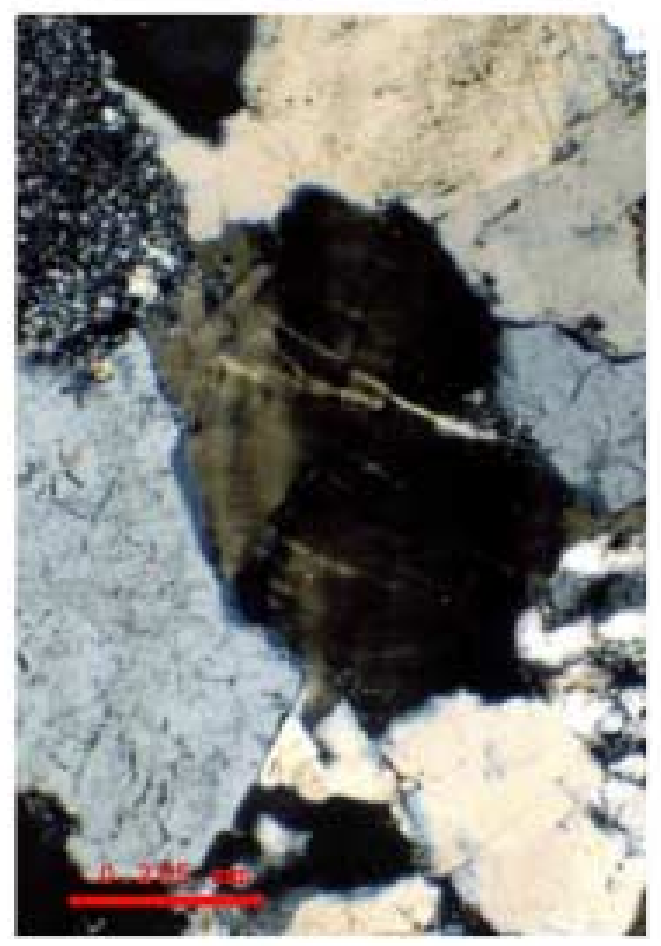

c.

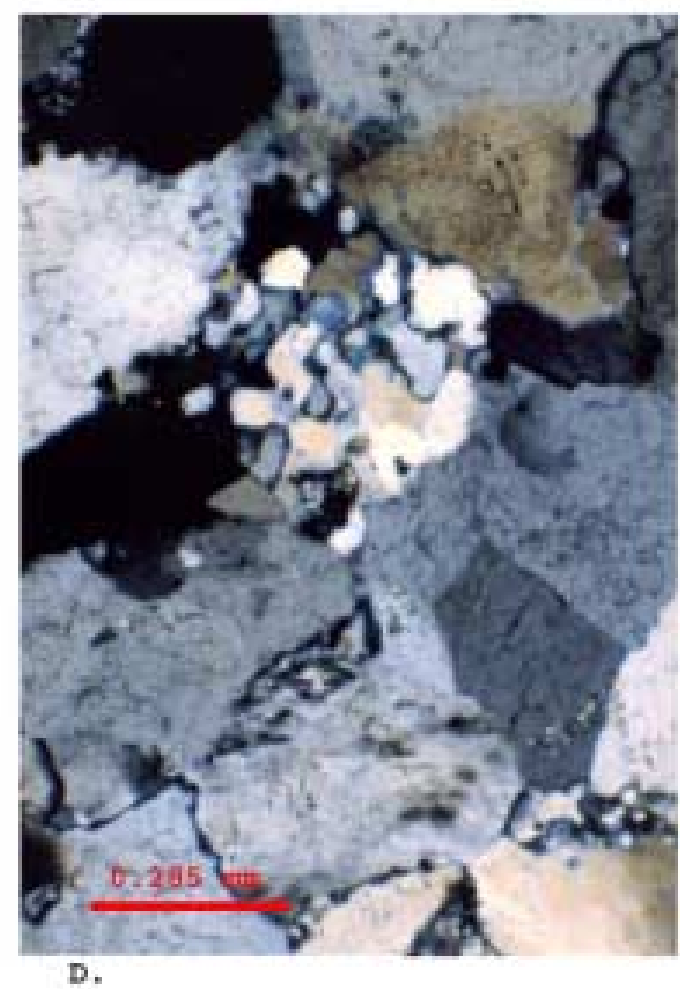

Figure 41: Lithic-rich sample (26-01) with abundant shale rock fragments in plain light (A) and in crossed nicols (B). C. Undulose quartz. D. Polycrystalline quartz. 
cleavage and twinning, low positive relief, and uniform or straight extinction with stage rotation.

Undulose, or wavy, quartz is a quartz grain in which the extinction shadow sweeps smoothly and without breaks across the grain as the stage is being rotated (Figure 41C). Wavy quartz can be further divided into slightly and strongly undulose based on the amount of stage rotation required for the shadow to sweep across the grain (Folk, 1968). For the purposes of this study however, a quartz grain was considered undulose if the grain did not go fully to extinction when the grain was rotated 90 degrees. In most cases, undulose quartz was the second most abundant grain of all the rock constituents, but in a few samples undulose quartz was more prevalent than normal quartz. Percentages of wavy quartz range from 13 to $43 \%$, with an average of $28 \%$ of the total rock volume. The third form of quartz is polycrystalline quartz. Polycrystalline quartz is thought to be metamorphic in origin. In thin section, polycrystalline quartz is colorless under normal light, and when the nicols are crossed the grain is seen to be composed of a mosaic of individuals (Figure 41D). Polycrystalline quartz percentages range from 0 to $34 \%$, with an average of $8 \%$ of the total rock volume. All three types of quartz vary considerably in shape from angular to subrounded, and they vary in size from .04 to 10 $\mathrm{mm}$. Chert is the forth type of quartz present but is remarkably less abundant than normal, wavy, and polycrystalline, with a range from 0 to $2 \%$ of the total rock volume. Chert is often considered to be polycrystalline in nature because it is made up of microcrystalline quartz, but the origin of chert is sedimentary rather than metamorphic (Folk, 1968; Scholle, 1979). Because the size of the microcrystals is arbitrary, for the purposes of this study, chert is defined as any quartz grain that is composed of many 
monocrystalline quartz crystals visible at high power, but indistinguishable at $5 \mathrm{X}$ or $10 \mathrm{X}$ power (Figure 42A; Mann, 1998).

\section{Feldspars}

Two varieties of feldspars are present. Plagioclase and microcline are present in extremely small amounts, with a range of 0 to $4 \%$ of the total rock volume, and an average of only $0.4 \%$. Of the two feldspars, plagioclase is more common and accounts for 0 to $2 \%$ with an average of $0.2 \%$ of the total rock volume. Plagioclase in thin section is recognized by its polysynthetic twinning, specifically Albite and Carlsbad twinning (Figure 42B). Microcline represents 0 to $2 \%$ of the total rock volume, with an average of $0.2 \%$. In thin section, microcline exhibits transformation twinning and is best recognized by its Scotch-plaid pattern (Figure 42C). Grains of feldspars range in size from 0.1 to $1.5 \mathrm{~mm}$. Generally the grains exhibit a subangular shape.

\section{Lithic Fragments}

After quartz, lithic grains are by far the most abundant grain type. Phyllite, schist, and shale are among the most common lithic fragments, in which collectively they constitute up to $26 \%$ of the total composition, with a mean of $11 \%$. Most rock fragments are ductile and have been compressionally deformed by compaction, and commonly are squeezed between stronger, more brittle quartz grains. Lithic fragments vary in size from pebble down to $0.1 \mathrm{~mm}$. The metamorphic fragments are characterized by foliation of constituent minerals. Phyllite is composed mainly of fine-grained micas, in which the 

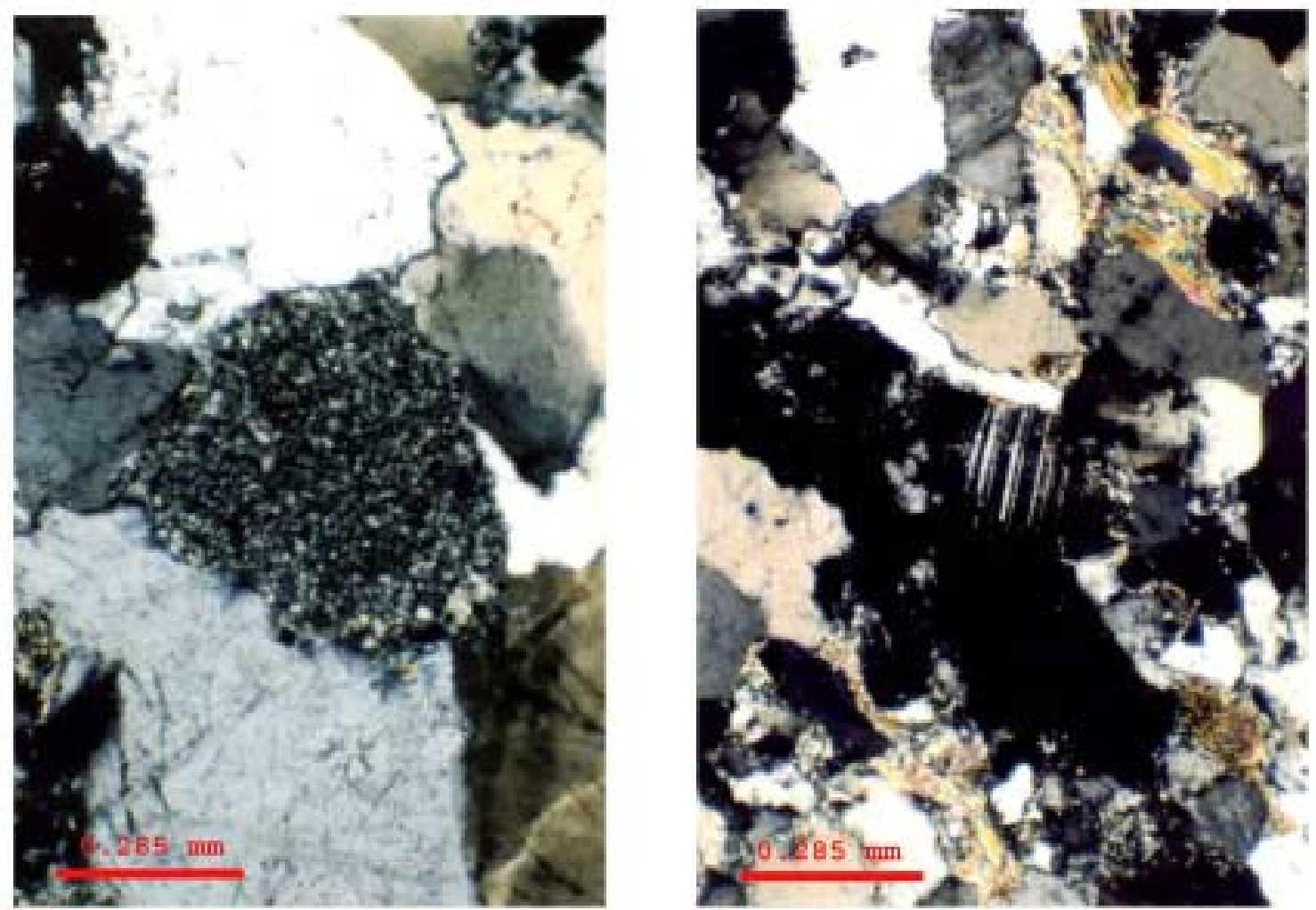

A.

B.

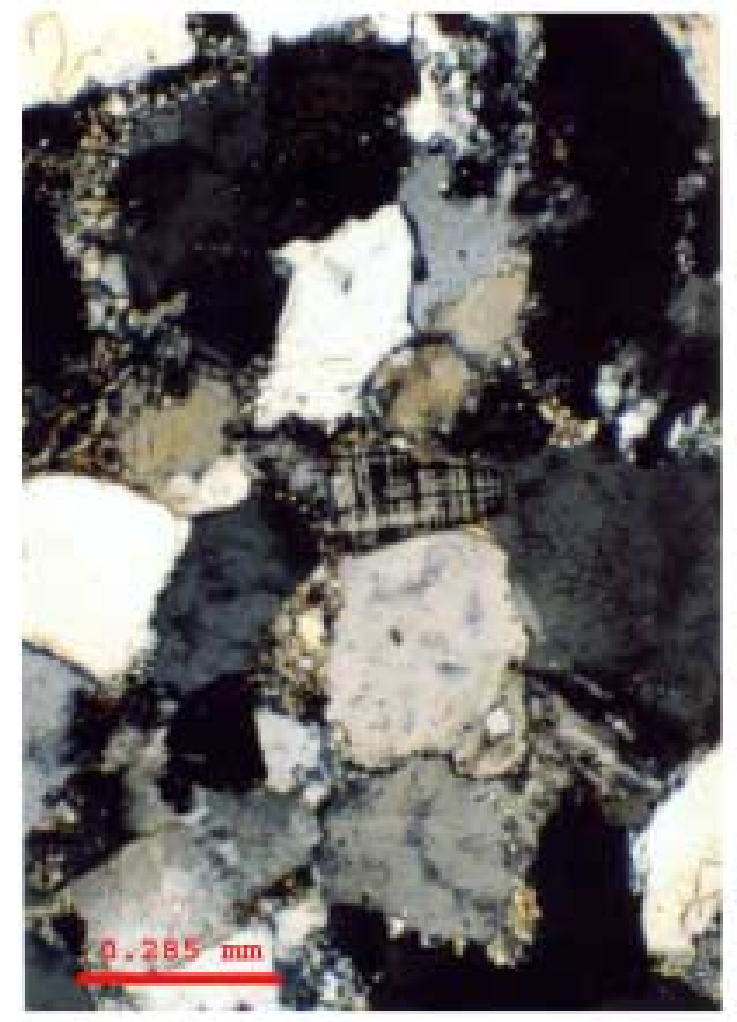

c.

Figure 42: A. Chert. B. Plagioclase feldspar. C. Microcline feldspar. 
micas are oriented parallel to each other, and when viewed under crossed nicols, the fragment is extremely colorful (Figure 43A-D). Phyllite fragments range from 0 to $8 \%$ with an average of $2 \%$ of the total rock volume. Schist is very similar to phyllite and also contains micaceous minerals that have parallel orientation, but in general has more quartz than phyllite and is coarse-grained (Figures 44A-B). Schist grains comprise 0 to $15 \%$ of the total rock percentage with a mean of $4 \%$. Sedimentary rock fragments average $4 \%$ of the total rock fraction with a range from $0-18 \%$. The main sedimentary rock fragment is mudstone, which constitutes an average of $4 \%$ and a range of 0 to $18 \%$ of the rock percentage. Mudstone fragments consist of clay-sized minerals, which may show parallel alignment. Under plain light mudstone fragments characteristically have a brownish color (Figure 41A-B). Other sedimentary lithic grains are present mainly in lag deposits and pebble conglomerates in moderate amounts. These grains consist of rip-up clasts of surrounding rocks usually argillaceous sandstone or siltstone.

\section{Micas}

Single large grains of mica vary in abundance, from 0 to $13 \%$, with an average of $3 \%$ of the total grains. Often times the micas are tabular in shape and structurally contorted, but a few grains are large and boxy. The majority of the micas are of two varieties: muscovite and chlorite. Muscovite grains are easily recognizable due to their high birefringence; under crossed nicols they are extremely colorful. In ordinary light, however, the grains are colorless (Figure 44C-D). Muscovite alone represents up to 9\% of the total rock volume, but averages less than $2 \%$ of the total rock volume. Chlorite in thin section appears much different from muscovite due to its high pleochroism, 


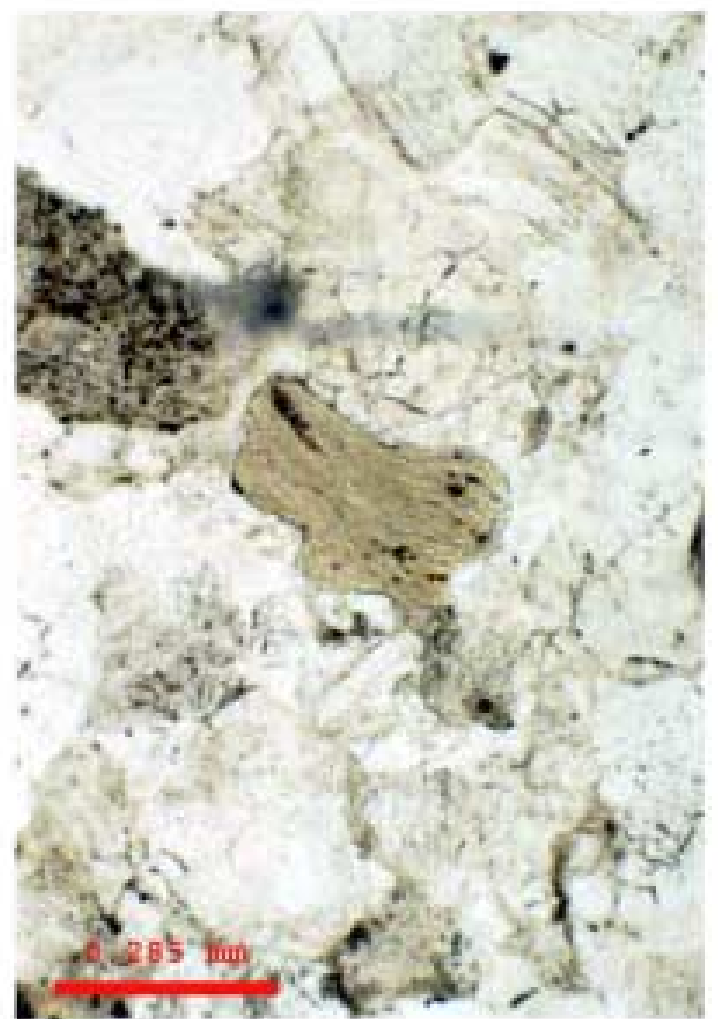

A.

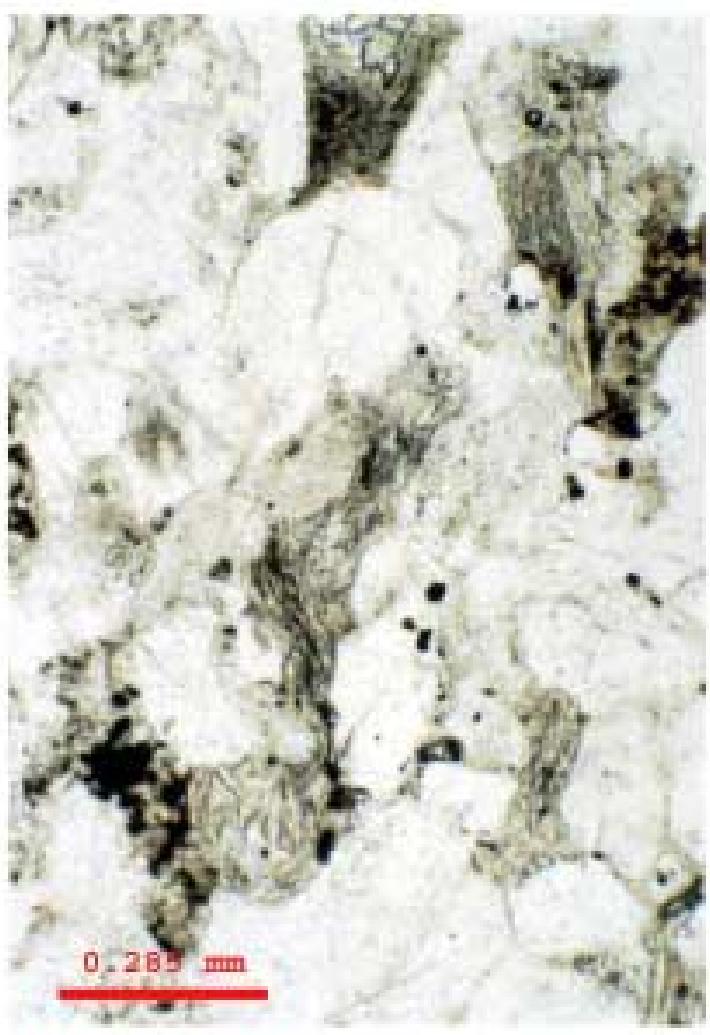

c.

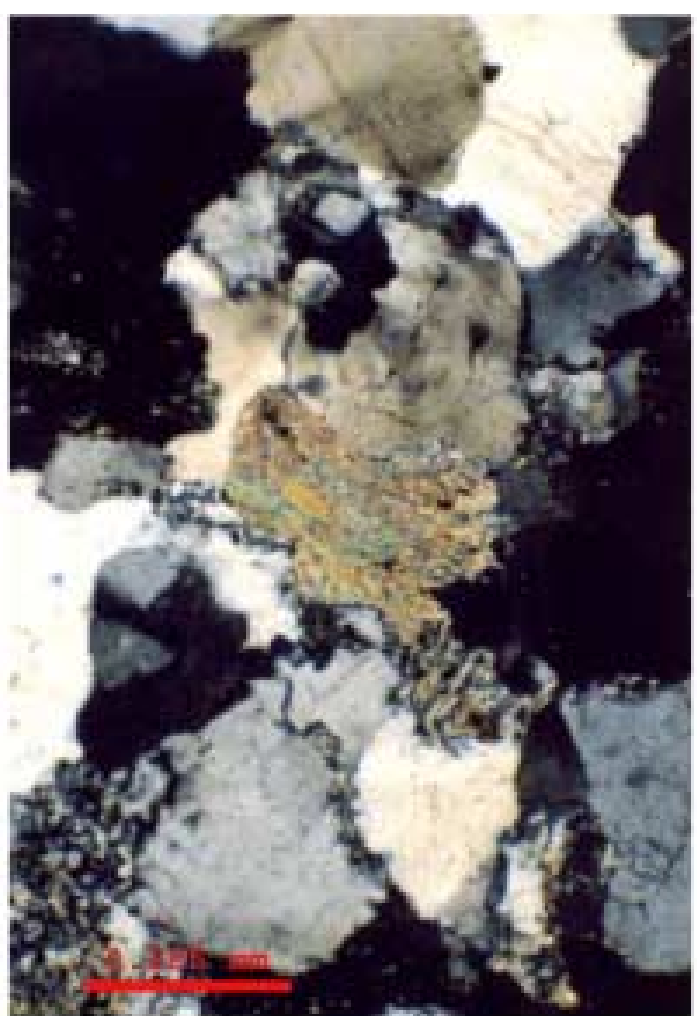

B.

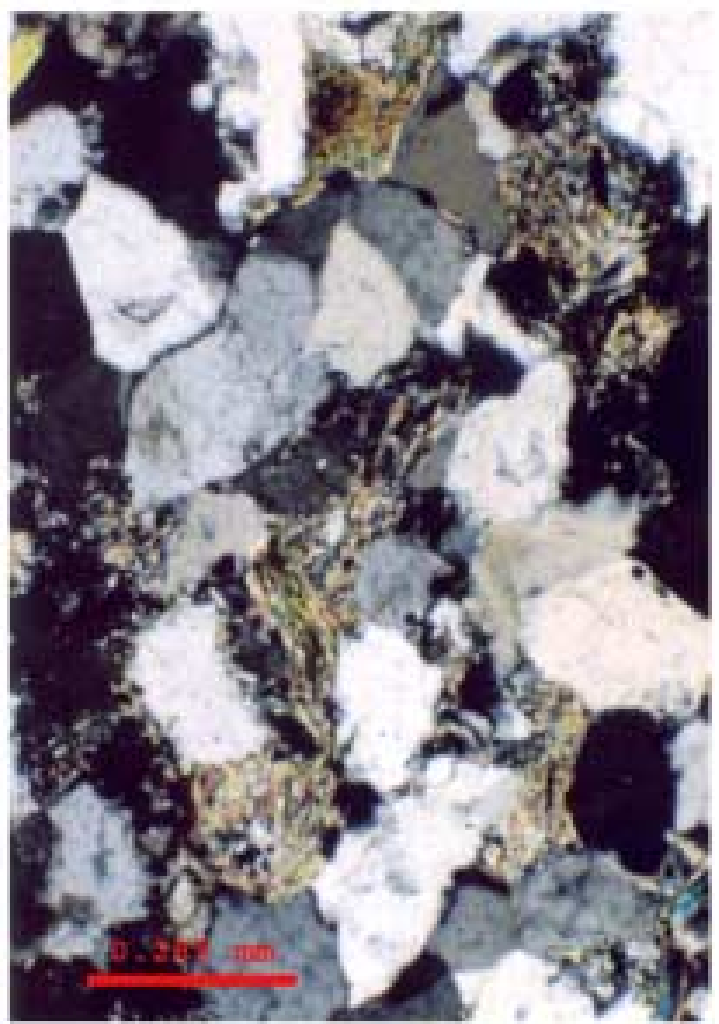

D.

Figure 43: Phyllite grain in plain light (A) and in crossed nicols (B). Sandstone with abundant rock fragments of phyllite (sample 38-08) in plain light (C) and in crossed nicols (D). 

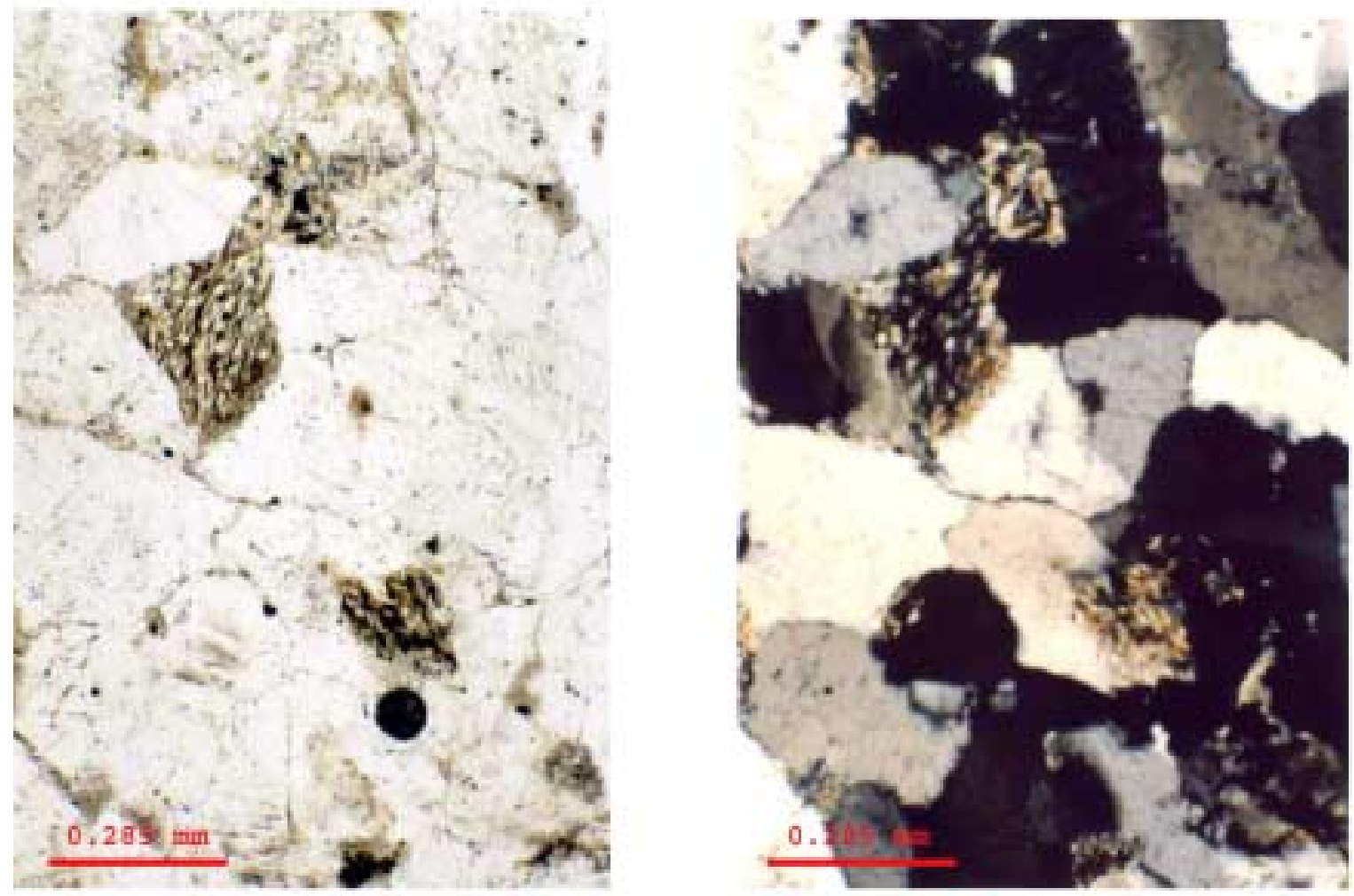

A.
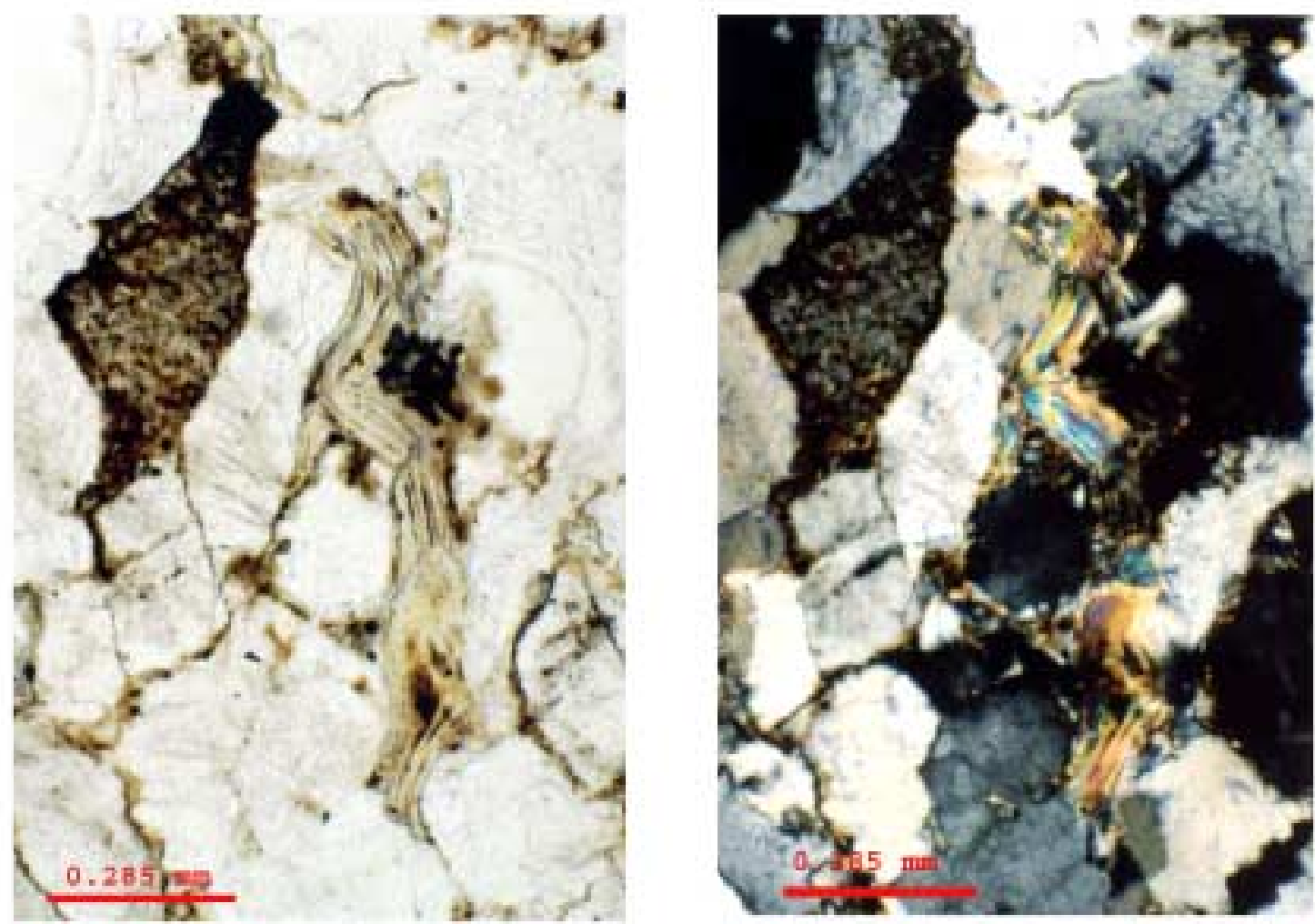

c.

D.

Figure 44: Schist rock fragment in plain light (A) and in crossed nicols (B). Deformed muscovite flake in plain light (C) and in crossed nicols (D). 
but low birefringence. Under ordinary light and crossed nicols, chlorite has a dark green color. Chlorite makes up to $8 \%$ of the total rock composition, but the average percentage of chlorite is only $1 \%$.

\section{Iron Minerals}

Iron minerals include pyrite, iron-oxides such as hematite and limonite, and siderite. Most iron minerals are secondary in nature. Collectively the iron minerals make up to $41 \%$ of the total composition but average only $4 \%$ of the rock volume. Pyrite is easily identified due to its opacity under both normal light and cross polarization, and when illuminated from above with reflective light, the pyrite grains reflect a gold color. In some samples pyrite nodules are present which account for the high percentages of pyrite in the total rock volume. Pyrite ranges from 0 to $7 \%$, but averages only about $1 \%$ of the total rock constituents. Iron-oxides, specifically hematite, can also be opaque in thin section, but they often appear reddish in color if thin enough (Figure 45A). Also, in reflected light the grains have a definite red hue to them. Iron-oxides can make up to $12 \%$ of the grains, and average about $2 \%$. Siderite is an iron carbonate, and frequently occurs as nodules or as a replacement for another mineral. Siderite at its highest concentration accounts for $41 \%$ of the rock grains, but averages only $1 \%$. Siderite is identified by its brownish color in both plain and polarized light, and also it often displays its characteristic rhombohedral cleavage (Figure 45B). 

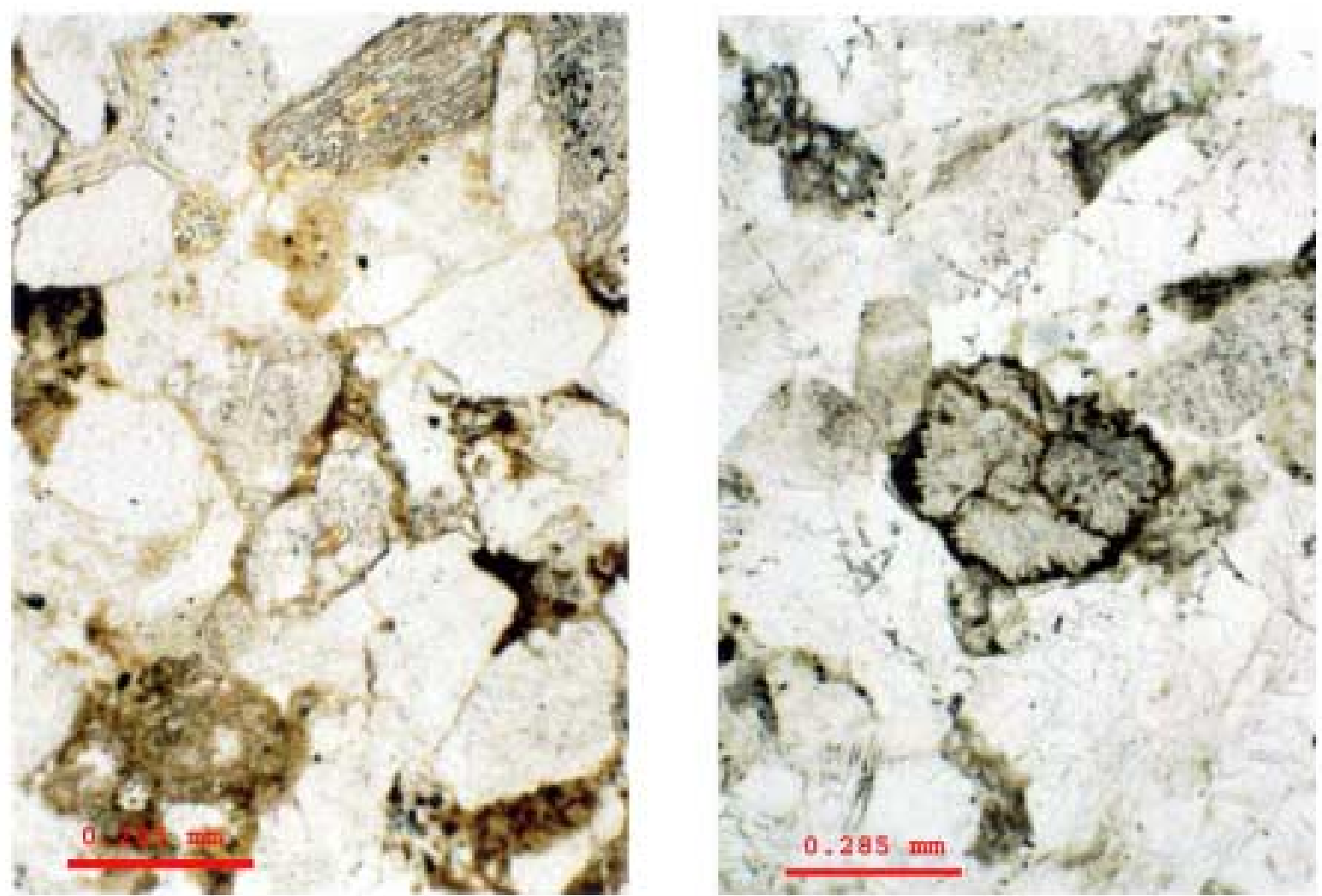

A.

B.
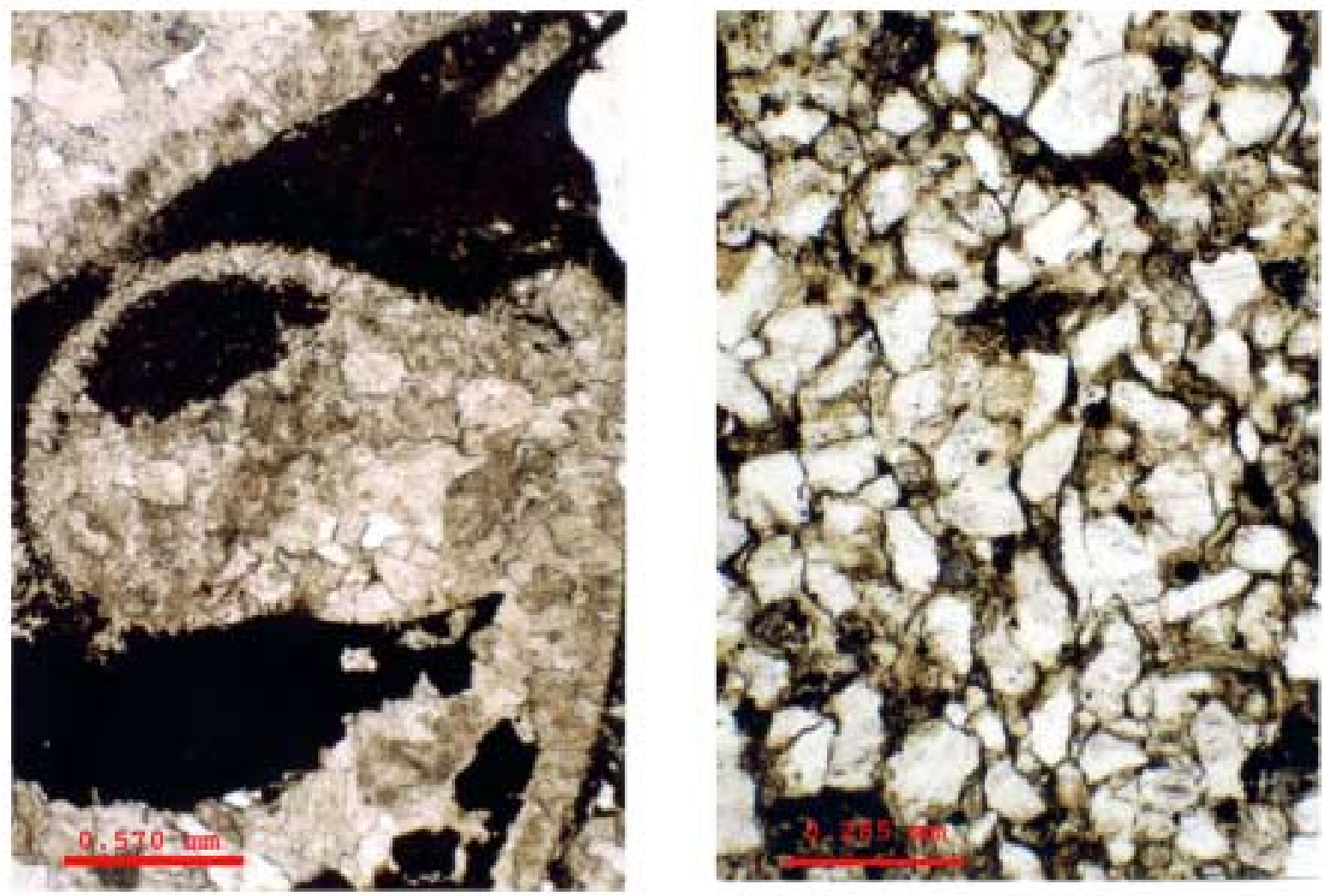

c.

D.

Figure 45: (A) Abundant hematite between framework grains in plain light (sample 39-06). (B) Siderite in plain light. (C) Gastropod and calcite crystals in plain light (24-02). (D) Sample with high matrix content (sample 29-01) in plain light. 


\section{Heavy Minerals}

Heavy minerals include zircon and tourmaline, both of which occur in trace amounts. At most the grains make up less than $2 \%$ of the rock volume, and both minerals occur at about the same frequency. Zircon is generally a small grain, but is identified by its high relief and strong to extreme birefringence. It is colorless under normal light, and frequently has a bipyramidal prismatic form (Scholle, 1979). Tourmaline however is recognized by its pleochroism, and appears yellow-brown color under normal light. In polarized light it has moderate to strong birefringence. In most cases, the tourmaline grains are blocky in shape, but generally small in size in comparison to the other more prominent grains.

\section{Calcite and Fossils}

Present in only two samples (lag-deposit samples) are carbonate crystals and fossil fragments, and therefore represent a very small percentage of the total grain constituents, with an average of less than $1 \%$. Calcite in its highest concentration makeup $18 \%$ of the total rock volume and is recognized by its high pleochroism, extreme birefringence, and rhombic cleavage. Because both calcite and dolomite are nearly identical in thin section without the aid of chemical stains, differentiation between these two minerals was not done, and the grains were simply classified as carbonate. The fossil grains, including gastropods, broken bivalves and bone fragments, are present in the two samples; they are broken and highly recrystallized making identification difficult (Figure 45C). At most fossils make up 13\% of the total rock volume, but average only $0.2 \%$. 


\section{Matrix and Cement}

Matrix is a clastic material that occupies the space between framework grains and usually consists of clay and silt-size particles of phyllosilicates, quartz and other minerals (Figure 45D). Sandstone matrix may contain both detrital and diagenetic components, in which detrital matrix is primary and reveals information about the provenance and transportations of the sediments, whereas diagenetic matrix is secondary and reveals information about post-depositional conditions. Matrix percentages vary within the Sherwood Lake sandstones from less than $1 \%$ to $50 \%$ of the total rock volume, averaging $11 \%$. Because of deformation and grain rearrangement during compaction, many lithic fragments were strongly deformed or squashed, producing a psuedomatrix that may be confused with matrix. Psuedomatrix is defined as highly deformed and recrystalized lithic fragments, and is considered diagenetic in its formation (Raymond, 1995; Figure 46A-B). In this study pseudomatrix was point-counted as matrix.

Cement is precipitated material that fills the interstices between grains, and in the Sherwood Lake outcrops consists mainly of quartz and in a few samples calcite. Quartz cementation commonly occurs as overgrowths that form in optical continuity with the underlying quartz grains, often making its identification difficult. Calcite cement is present only in two samples. On average, cement makes up $2 \%$ of the total rock volume, but ranges from little or none up to $7 \%$. 


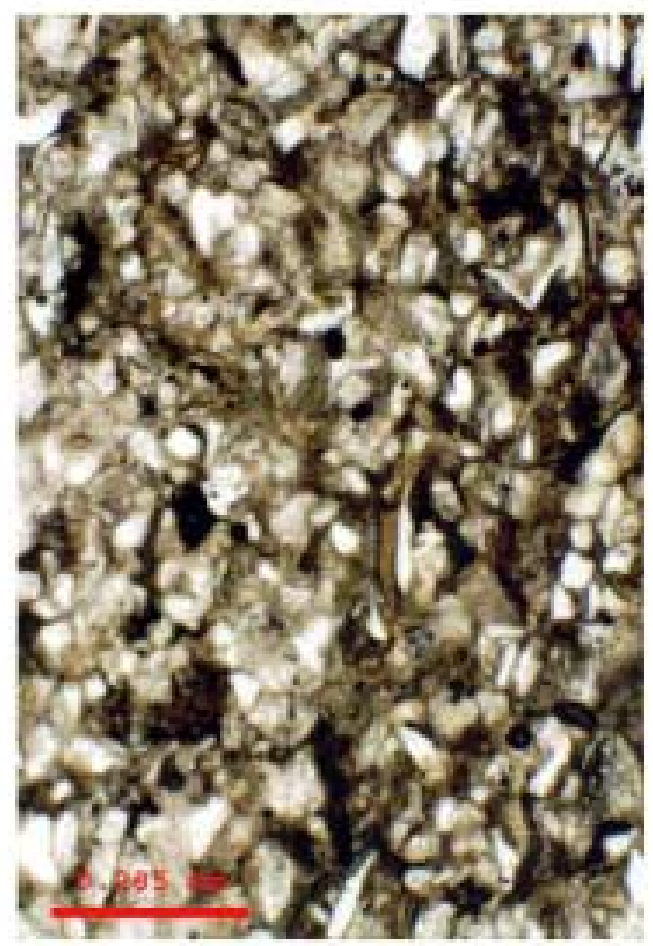

A.

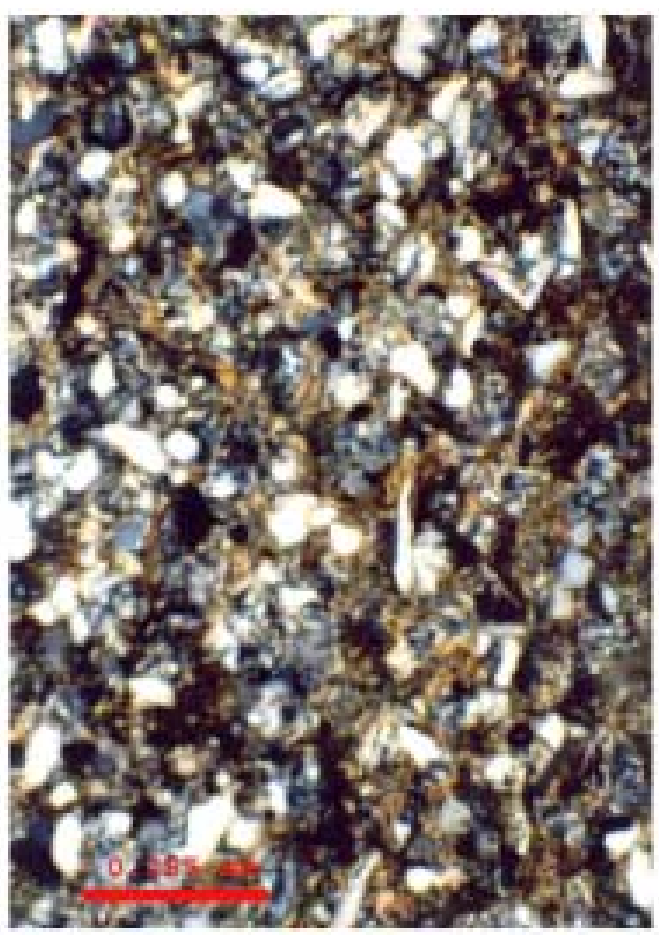

B.

Figure 46: Sample (12-01) with high pseudomatrix content in plain light (A) in and crossed nicols (B). 


\section{Petrologic Interpretation}

The distribution of various kinds of particles in thin-sections was quantitatively analyzed by point counting, in which 300 points were counted per slide. Within the fiftyseven thin sections, a total of nineteen grain types, including matrix/pseudomatrix, and two types of cements were encountered. After counting was completed, each grain type was then divided by three in order to get its actual percentage. Various ternary diagrams were then constructed so that the composition of the sandstones can be analyzed.

Of the seven facies present at Sherwood Lake, six of the depositional environments contain sandstones that were petrographically analyzed: fluvial facies, distributary facies, crevasse-splay facies, interdistributary bay, lagoonal facies, as well as a beach-bar facies. Although the coal found in the interdistributary swamp facies was sampled, none were analyzed thin section.

Point-count data reveals that there are petrographic differences among the six facies and trends in the mineralogy across the Price delta-plain. The most distinct differences occur in the percent of lithics, quartz, micas, as well as matrix present. However, good grouping occurs when the sandstones of all the facies are plotted on a quartz, feldspar, and lithics ternary diagram (QFL diagram) (Figure 38). Because all the samples were taken from sandstone beds within the Sherwood Lake area (very small geographic range), variations in the quantities of major components such as quartz and feldspar between facies are not likely to vary significantly since they all are derived from the same source. What is significantly different, though, is the amount of lithics in each facies, as well as the type of lithics. Hence, the most significant compositional variations among the sandstones can be displayed as ternary plots where the three apices are 
sedimentary rocks (primarily shale) fragments, phyllite fragments and schist fragments (SPS diagram) (Figure 39).

\section{Meandering Channel Facies}

Fluvial sandstones of the meandering channel facies have a total quartz content that averages $75 \%$ with $81 \%$ quartz being the highest and $65 \%$ being the lowest. Monocrystalline quartz comprises about $45 \%$ of the total quartz volume and undulose quartz about $40 \%$. Over $12 \%$ of total rock volume is lithic fragments, of which the majority are schist grains. All the fluvial sandstones can be classified as sublitharenites (Figure 47; Folk, 1968).

Aside from quartz and lithic fragments, iron minerals and micas make up the majority of the remaining grains, collectively averaging about $7 \%$ of the total rock constituents. Muscovite grains comprise an average of $96 \%$ of the total mica grains. Within the fluvial sandstones, the individual grains of muscovite are large in comparison to other facies, and are similar in size to the framework quartz and lithic grains. Iron minerals, specifically the iron-oxides are common in all the samples with especially high percentages in sample 39-03 and 39-06. Generally iron-oxides are found between grains of quartz and lithic fragments. Matrix percentages range from 0 and $4 \%$, with an average of $1.6 \%$ and cement percentages range from 1 to $6 \%$ and average about $2.8 \%$.

When the fluvial sandstones are plotted on a SPS diagram, a distinct clustering is visible (Figure 48). Schist grains are by far the most abundant of the lithic fragments ranging from 47 to $79 \%$ of the total lithic percentages, and averaging about $63 \%$. 


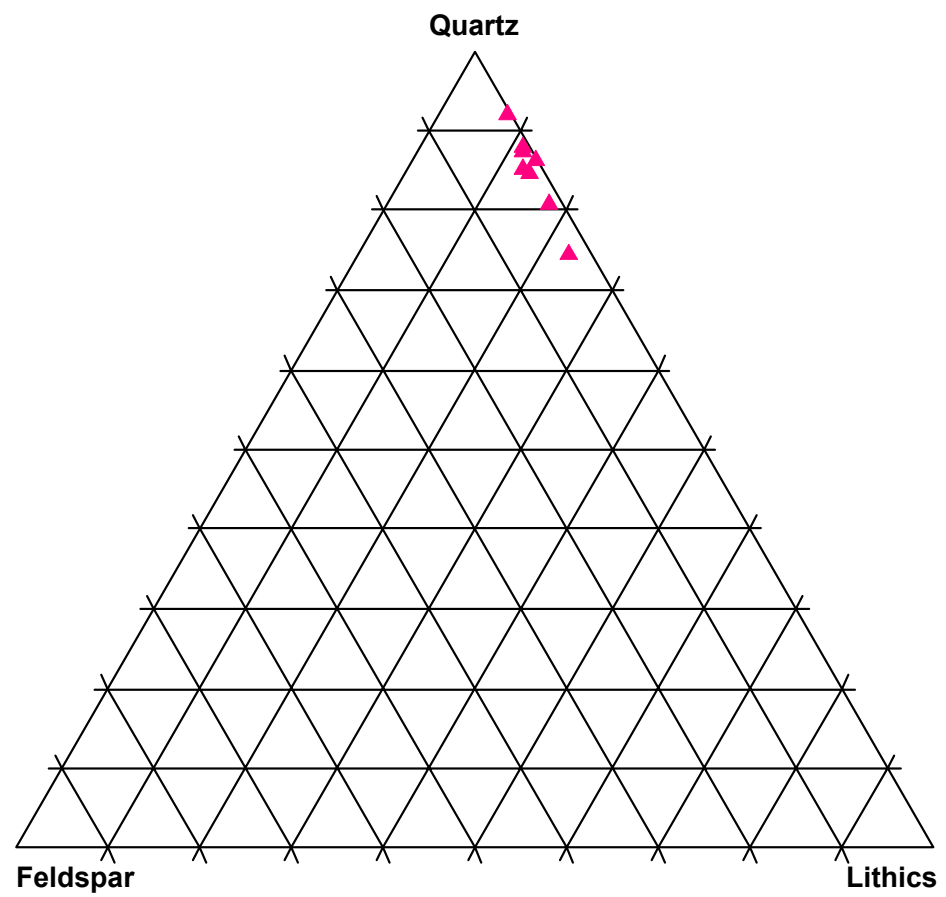

Figure 47: QFL diagram for all 8 samples indicative of the fluvial facies.

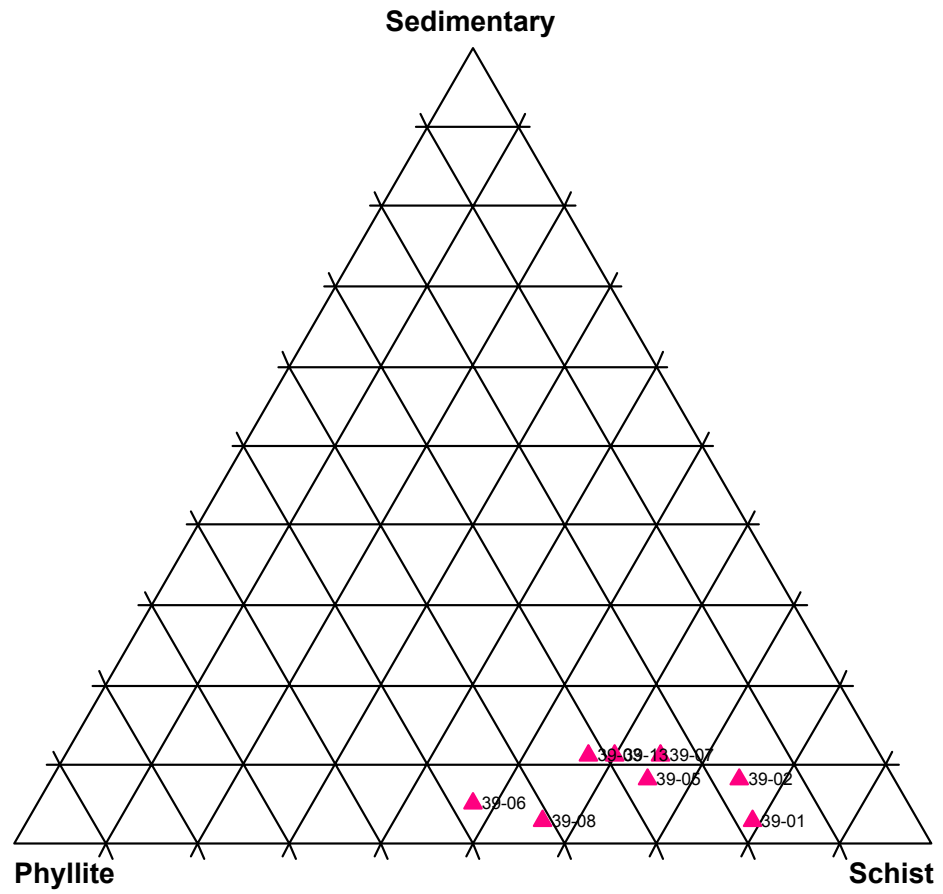

Figure 48: SPS diagram for fluvial facies. 
Phyllite grains were the next most abundant rock type averaging $29 \%$ of the lithic volume, but ranging from as low as $17 \%$ and as high $47 \%$. The sedimentary rocks present in the facies were strictly shale fragments, but were only a small percentage of the rock volume, averaging about $8 \%$ and ranging from 3 to $11 \%$ (i.e., nearly all of the lithic fragments are metamorphic).

\section{Distributary Channel Facies}

Distributary channel facies are by far the most prevalent facies present at Sherwood Lake, comprising over 15 meters of section. Therefore, in order to accurately represent the facies, 14 samples were taken for thin-section preparation, representing about one quarter of the total thin-section samples. Based on mineralogy differences and position on the delta-plain, the facies can be divided into two groups: upper distributary channels and lower distributary channels.

All of the sandstones present in the upper distributary channel facies can be classified as sublitharenites (Folk, 1968; Figure 49). Total quartz content within the facies ranges from 65 to $80 \%$ of the total rock volume and average about $74 \%$. The majority of the quartz is monocrystalline and undulose, but polycrystalline quartz also attains significant percentages, yielding the highest average percentage $(11 \%)$ of all the facies. Likewise, lithic fragments are a significant percentage of the total rock constituents, averaging about $13 \%$, with a range from 9 to $19 \%$. In most cases metamorphic lithic fragments are more abundant than the sedimentary rock fragments. Of the metamorphic grains, phyllite is the more dominant grain in most samples. 


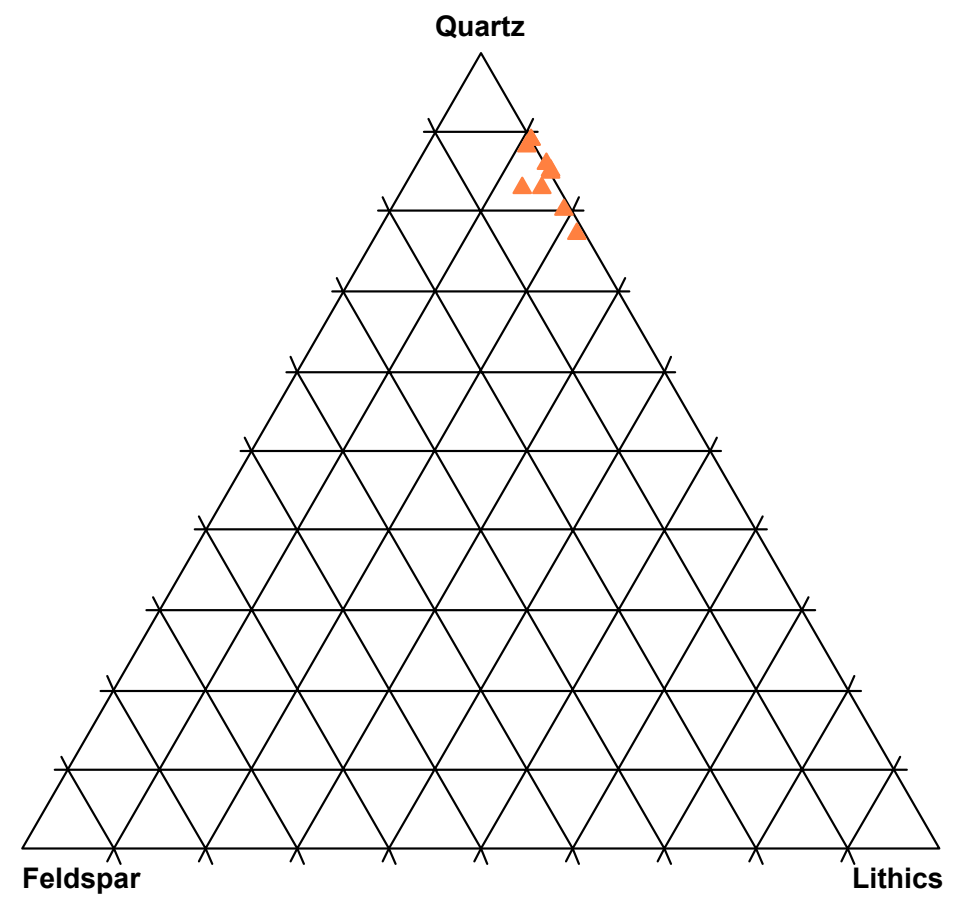

Figure 49: QFL diagram plotting all 10 upper distributary channel samples.

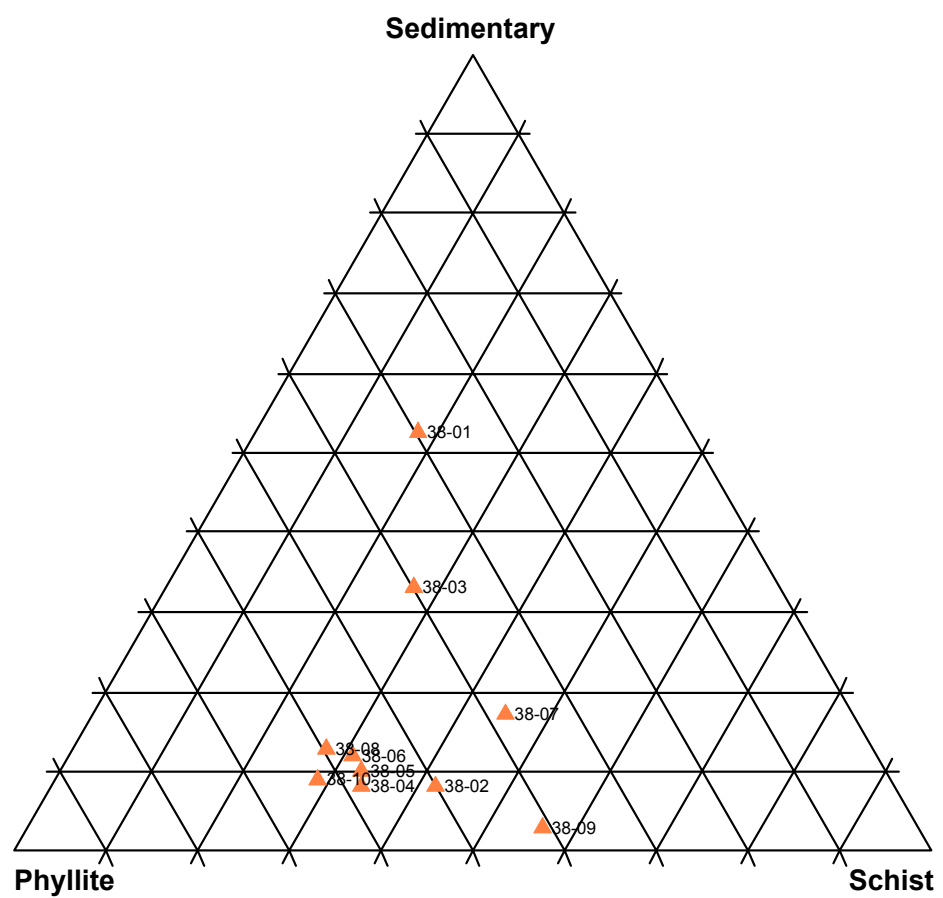

Figure 50: SPS diagram of the upper distributary channel facies. 
Micas, in most cases muscovite, account for less than $2 \%$ of the total volume, and range from 0 to $4 \%$. Of the iron oxides present, hematite is the most frequent, and is common as a secondary mineral. Normally hematite is present in the interstices between quartz and lithic grains. High percentages of quartz cement occur as overgrowths around the detrital quartz grains. These overgrowths, however, reflect diagenetic processes rather than depositional. Matrix is absent in the majority of the samples, and where present only averages about $1 \%$ of the total rock constituents. This lack of matrix within the facies, is a good indicator that the flow regimes in these channels were relatively constant and energetic.

When plotted on a SPS diagram, the upper distributary channel samples yield one major group with only a few outliers (Figure 50). These ten samples have large percentages of phyllite and schist, which are the most durable of the rock fragments. Phyllite percentages in these samples range from 30 to $63 \%$ and schist ranges from 18 to $45 \%$ of the total lithic volume. Shale grains range from 3 to $53 \%$ of the total lithic volume. Samples of the upper-delta-plain distributary channel were collected at outcrop 5 and represent distributary channels that are very similar to fluvial facies. These distributary channels were of significant size and probably less susceptible to avulsion than were those of the lower-delta-plain.

Sample 38-01 is the most significant outlier within the upper distributary channel samples. $10 \%$ of its total rock volume, and more than $50 \%$ of its total lithic volume is shale. This sample was taken from the base of the unit, where there is a minor basal conglomerate, dominantly made up of small shale clasts; probably eroded from locally from underlying bituminous shale. 
Sandstone samples of the lower distributary channel facies can be classified as sublitharenites and litharenites (Figure 51; Folk, 1968). A closer look at the mineralogy indicates that an average of only $62 \%$ of the actual grains are quartz. In these samples, the lithic fragments and matrix constitute major volumes.

Lithic fragments make up an average of over $21 \%$ of the rock volume and are evenly distributed among sedimentary and metamorphic grains. Iron minerals, generally hematite, vary within the facies and can represent up to $8 \%$ of the total rock volume. Chlorite and muscovite grains are present in all samples within the facies, but on average represent only $4 \%$ of the total grains.

Matrix within the lower distributary channel facies averages $7 \%$ of the total rock volume and is present within all of the samples, which differs significantly from the matrix percentages in the upper distributary channel. This is most likely is because a wide variety of sizes and shapes of distributary channels exist across the lower-delta-plain. As these channels divide and become broader and shallower while they move seaward, a wide variety of flow regimes may be encountered.

The lower-delta-plain grouping is composed of 4 samples that were collected from outcrop 4. All the samples clearly have more sedimentary rock fragments present than do the distributary channels located on the upper-delta-plain as shown in the SPS diagram (Figure 52). In all cases, the sedimentary rocks are exclusively shale. Shale percentages of lower distributary channels range from 42 to $59 \%$ of the total lithic volume, whereas phyllite is only responsible for 12 to $19 \%$, and schist from 27 to $44 \%$. 


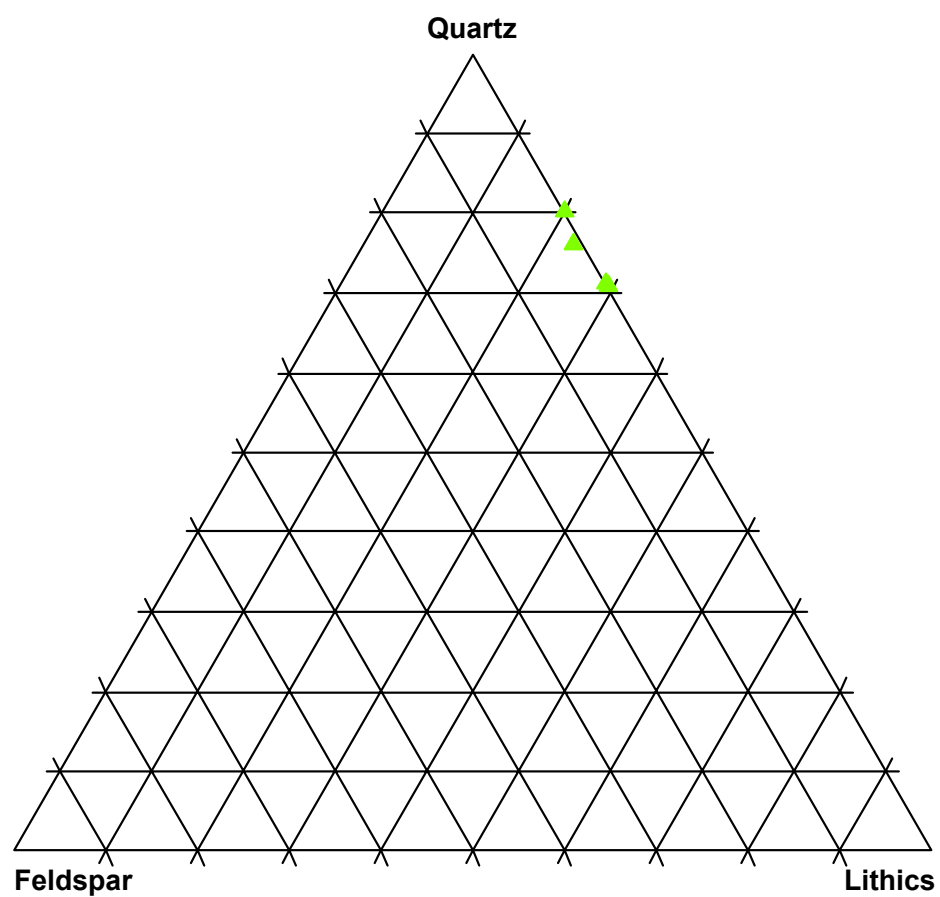

Figure 51: QFL diagram for all 4 samples of the lower distributary channel facies. Note that samples 34-01 and 32-04 have nearly identical percentage, and together appear as one triangle.

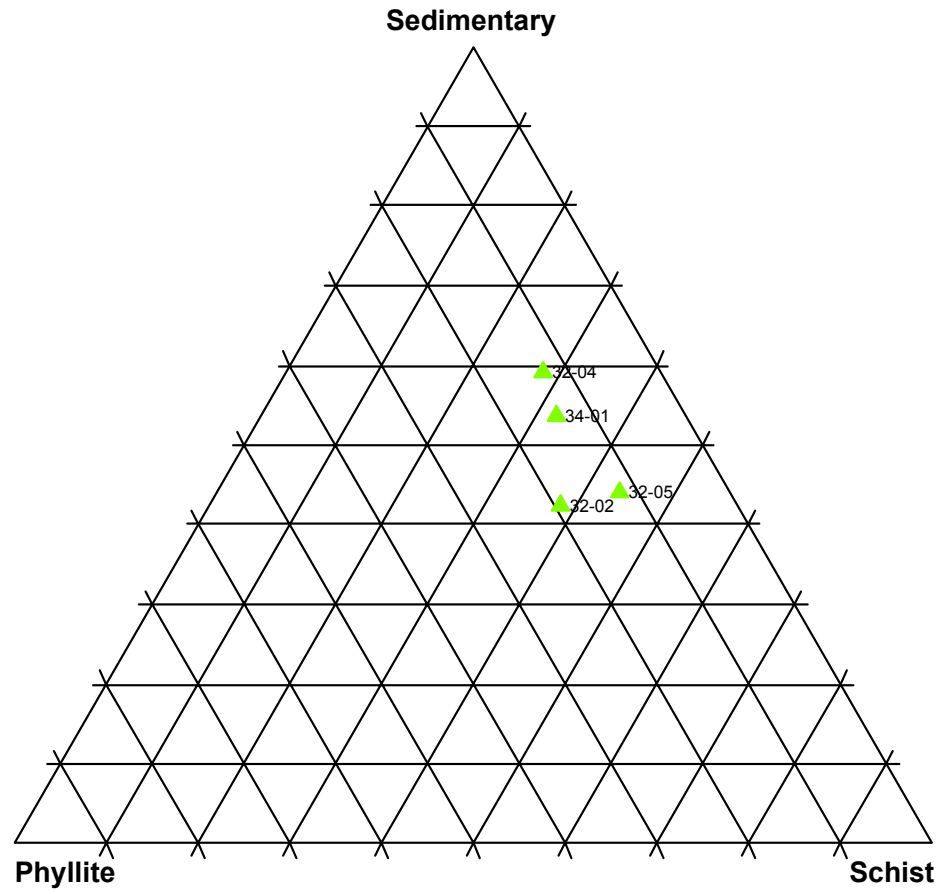

Figure 52: SPS diagram for lower distributary channel facies. 


\section{Crevasse-Splay Facies}

Crevasse-splay sandstones have the highest percentages of quartz than all the other facies, with an average total quartz percentage of $85 \%$ and a range from 84 to $87 \%$ of all the rock constituents. About equal percentages of normal quartz and undulose quartz are present, collectively accounting for $87 \%$ of the total quartz volume. Lithic fragments are somewhat common averaging about $8 \%$ of the total grains present and ranging from 7 to $10 \%$. The most common lithic fragment is schist, with an average of $6 \%$, whereas phyllite and shale each account for about $1 \%$ of the total volume. All samples that represent the crevasse-splay deposits can be classified as sublitharenites (Figure 53) (Folk, 1968).

Less abundant minerals present in the crevasses-splay rocks are iron minerals and matrix, which combined account for $4 \%$ of the total rock volume. The most common iron mineral present is identified as iron oxide, most likely hematite. Hematite ranges from less than 1 to $4 \%$ of the total constituents for crevasse-splay deposits, but averages about $2 \%$. Matrix accounts for an average of $2 \%$ of the rock volume and range from about 2 to $3 \%$.

\section{Beach-Bar Facies}

The beach-bar samples at Sherwood Lake can be classified as quartzarenites, sublitharenites, and also litharenites indicating that the range of quartz and lithic percentages varies widely within the facies (Figure 55). Quartz ranges from 33 to $93 \%$ of 


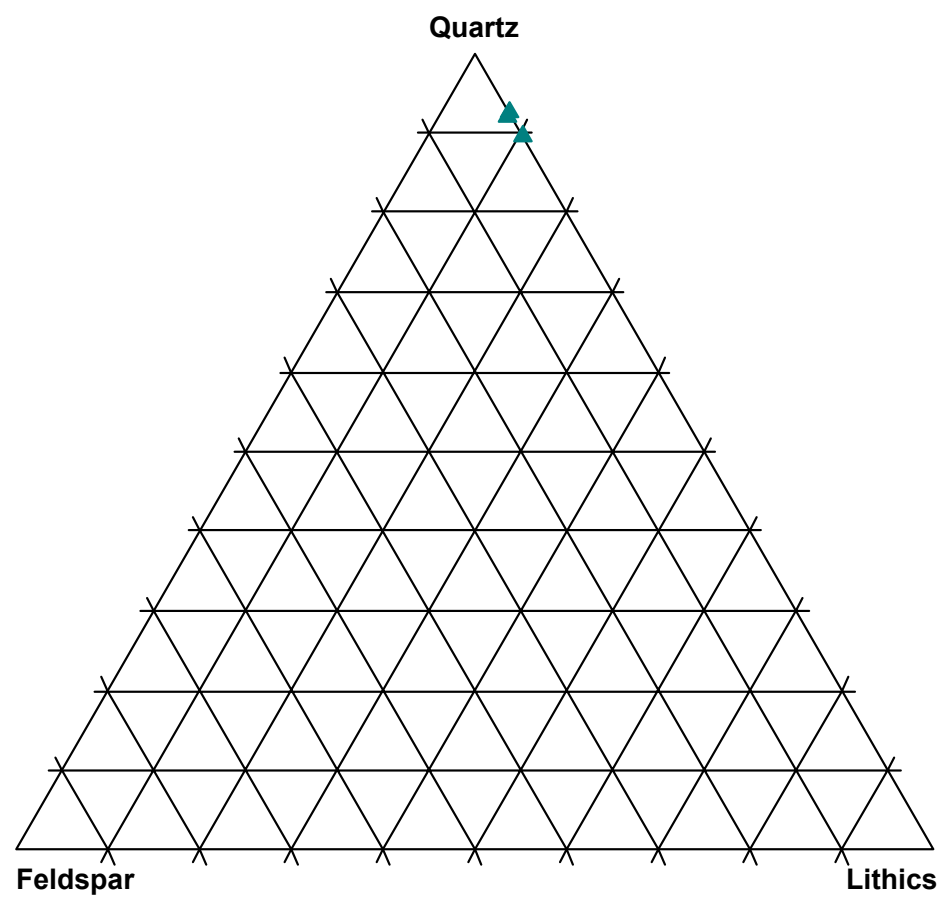

Figure 53: QFL diagram for the 3 samples indicative of upper crevasse-splay facies. Note that only two appear visible as samples 37-01 and 37-03 have nearly identical percentages.

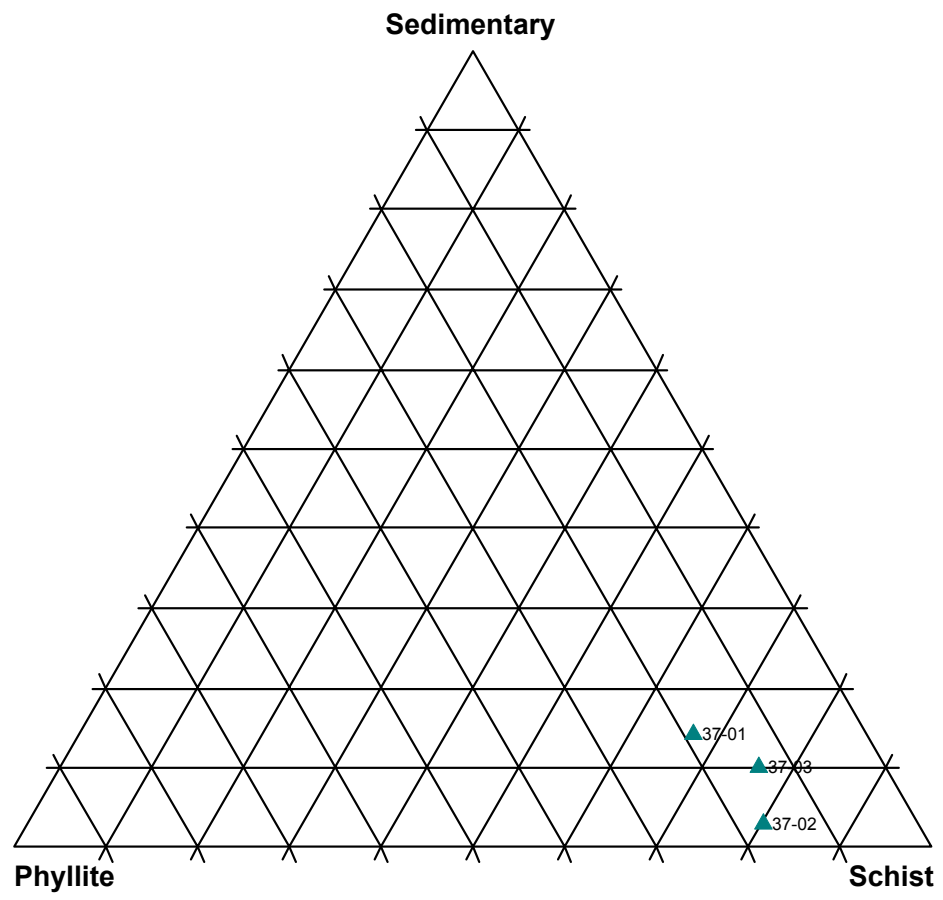

Figure 54: SPS diagram for upper crevasse-splay facies. 


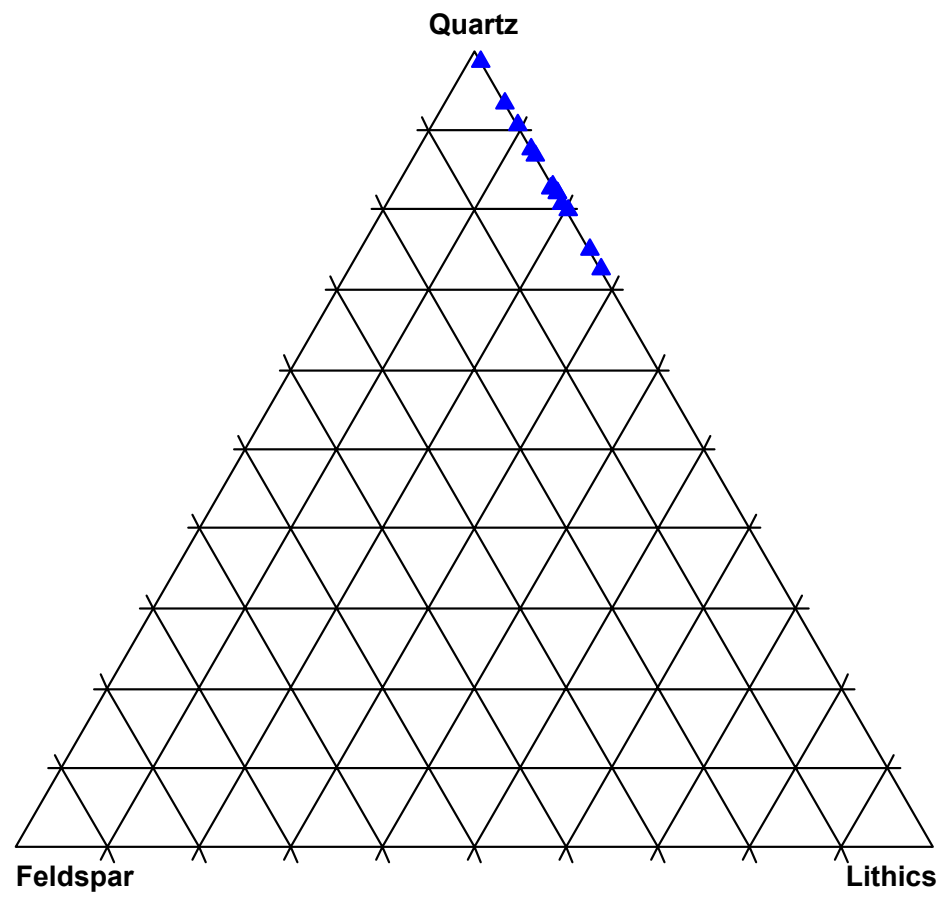

Figure 55: QFL diagram for the 13 samples representing the beach facies

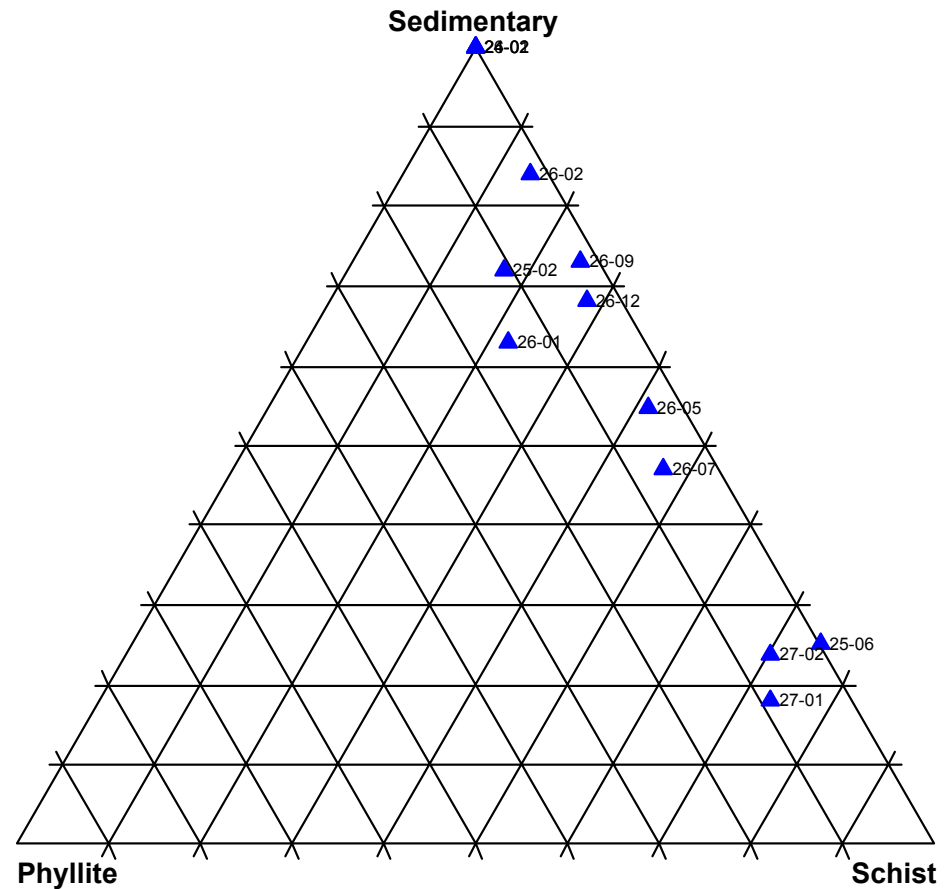

Figure 56: SPS diagram for the beach facies. Note that samples 24-01, 24-02, and 2603 all have sedimentary rocks as the only type of lithic fragment, and therefore appear as one data point. 
the total rock volume and averages about $67 \%$ of the mineral content. Rock fragments are rather common within the samples ranging from 1 to $18 \%$, with a mean of $12 \%$. Mainly the samples contain shale and schist as the dominant lithic grains, but in a few cases lithics of other sedimentary rocks are dominant, and are generally rip-up clasts of the sandstone itself. Matrix is responsible for about $12 \%$ of the total rock volume, but ranges from less than $1 \%$ to $36 \%$.

Samples 24-01 and 24-02 contain both carbonate crystals and fossil fragments in rather significant amounts, and are representative of the trangressive lag deposit. In these two samples, carbonate constituents range up to 18 and $13 \%$ respectively. Fossil fragments are broken and recrystallized. The cement in both samples is calcite and ranges up to $7 \%$ of the total rock volume. Coincidentally, samples $24-01$ and 24-02 are the samples that contain the sandstone rock fragments, also indicating the lag nature of the unit.

When plotted on a SPS diagram, the samples are indicative of a beach-bar environment and show two distinct groups (Figure 56). The majority of the samples contain sedimentary rocks as the dominant lithic grain. These samples are interpreted as being located within the shoreface. In most cases the dominant sedimentary rock fragment present is shale and ranges in percentages from as little as none to $13 \%$. The second group, however, has fewer samples and the dominant rock fragment present is schist. Schists percentages range from 1 to $8 \%$ of the total composition These samples are interpreted as being located within the foreshore. 


\section{Lagoon Facies}

Three samples indicative of the lagoonal facies were analyzed for thin-section data. Quartz is the major component of the samples, comprising over $51 \%$ of the total mineral count. Lithics, primarily shale fragments, account for $12 \%$ of the samples. When plotted on a QFL diagram the samples indicate that the facies is dominantly sublitharenite in composition (Figure 57). Matrix is a major component of the total rock volume, totaling over $23 \%$. Minor minerals include the iron minerals, which are collectively responsible for $5 \%$ of the mineral make-up. Both pyrite and iron oxides are present in equal amount. Micas are responsible for $6 \%$ of the makeup, in which muscovite is slightly more common than chlorite.

When plotted on a SPS diagram, the lagoonal facies indicates that the majority of the rock fragments are shale, with a small percentage being schist and phyllite (Figure 58). The presence of shale interbeds is very common with the lagoonal sandstones, and shale rock fragments probably result from erosion of organic-rich muds on the lagoonal floor.

\section{Interdistributary Bay Facies}

The interdistributary bay facies is about 14 meters of the entire Sherwood Lake section, and outcrops in the first three exposures. 17 samples are representative of the facies. When plotted on a QFL diagram, samples of the interdistributary bay can be classified as both quartzarenites and sublitharenites, with one exception being a litharenite because of its high rock-fragment content (Figure 59). Within the 


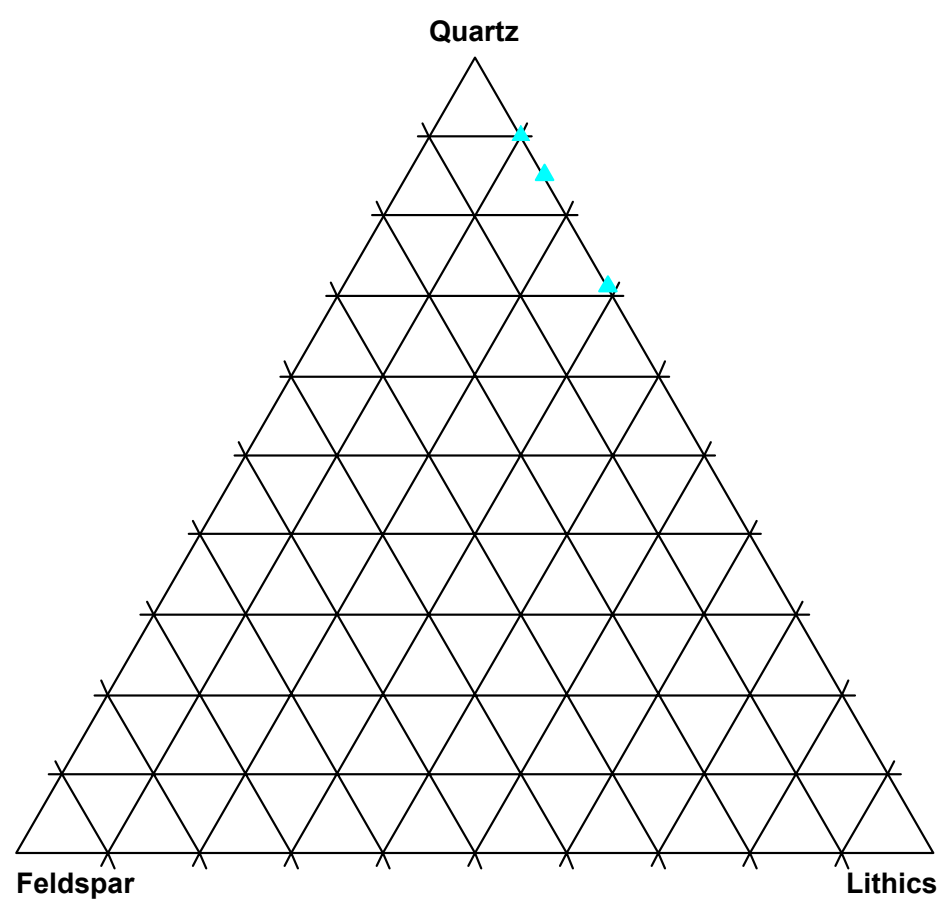

Figure 57: QFL diagram for all samples indicative of the lagoonal facies.

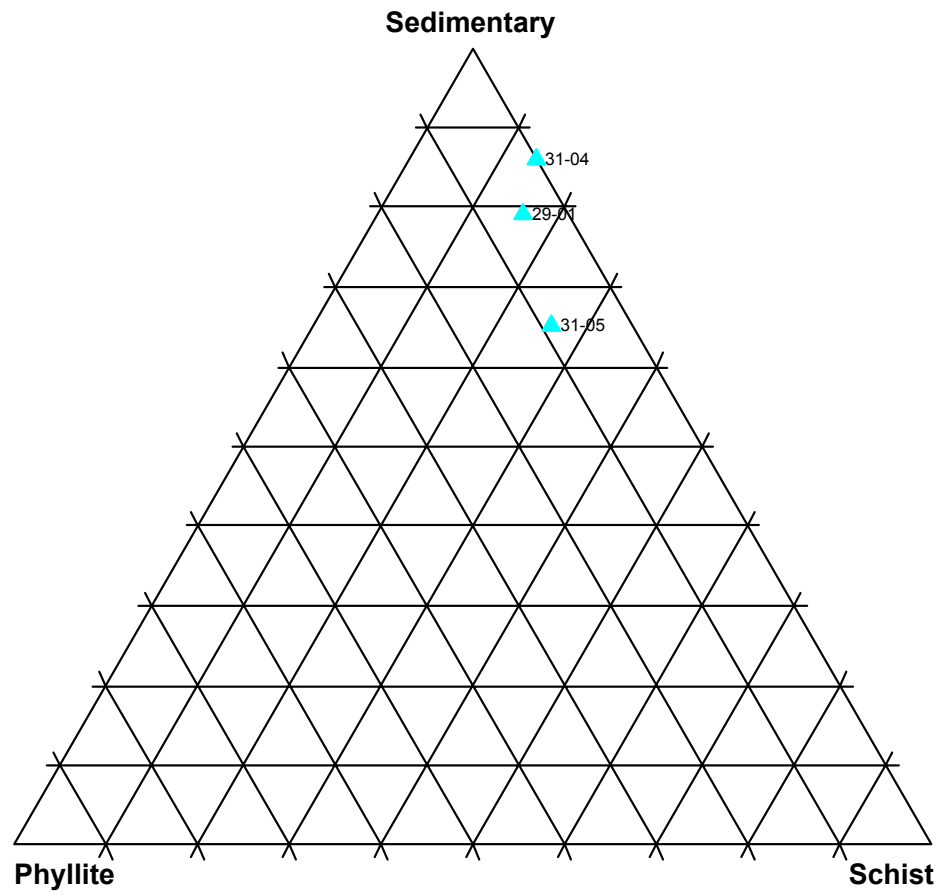

Figure 58: SPS diagram for lagoonal facies. 


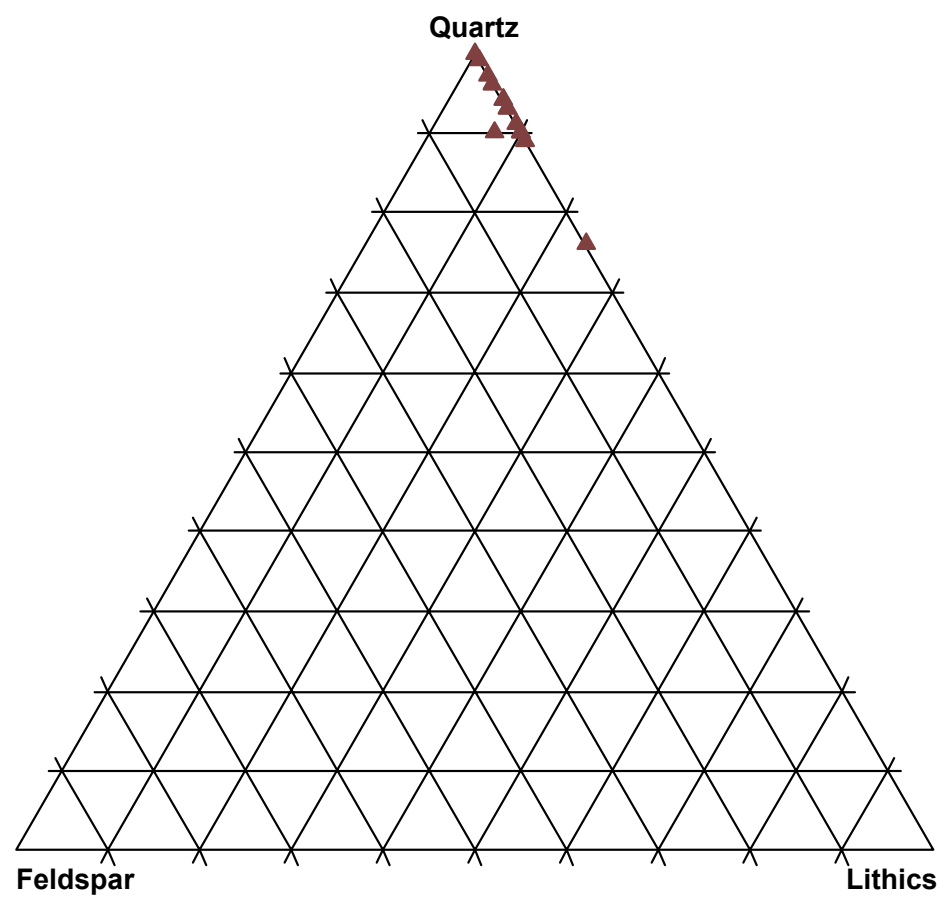

Figure 59: QFL diagram for the 16 sample indicative of the bay-fill facies. Note that some samples have identical percentages, and occupy the same triangle space.

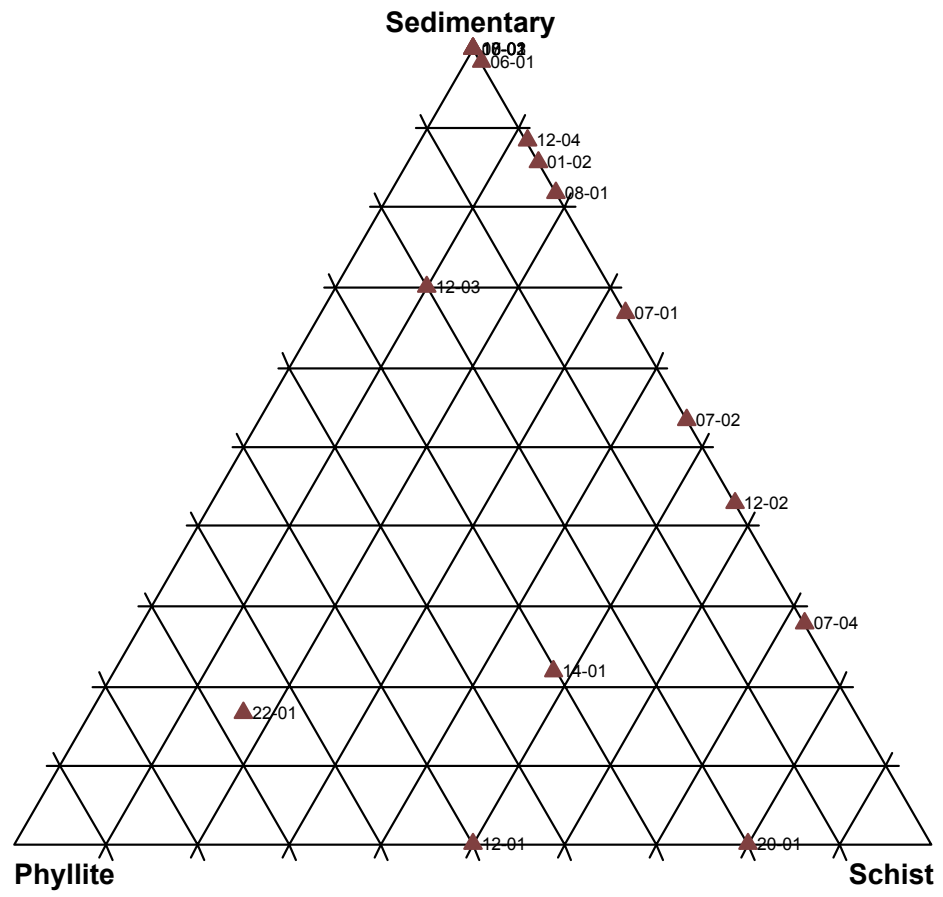

Figure 60: SPS diagram for interdistributary bay facies. There are 16 samples total in the facies, note that samples 201-01 and 10-10 have identical percentages, therefore appear as one triangle. 
interdistributary bay samples, quartz is commonly the dominant grain ranging from 38 to $81 \%$ and averaging $62 \%$ of the total mineral content. A closer look at the mineralogy, however, indicates that in many of the samples the quartz volumes are comparatively low and the matrix volumes relatively high, with values ranging from 3 to $50 \%$ of the rock content.

Small percentages of micas and rock fragments are present and account for about 3 and $5 \%$ of the total volume respectively. The micas, both muscovite and chlorite, are equally common in these samples and range from 1 to $4 \%$ and 1 to $2 \%$ of the total constituents, respectively. Rock fragments are rather uncommon in comparison to the other facies, and this may be due to the large volumes of pseudomatrix present. If rock fragments are squashed and deformed between grains that are more brittle, then it becomes nearly impossible to distinguish a true a rock fragment from matrix. Iron minerals are somewhat common, and pyrite is the dominant iron component comprising over $2 \%$ of the total rock percentage. Pyrite occurs as both nodules and individual crystals within the facies. A high percentage of replacement siderite is present in sample 07-01, which has $41 \%$ siderite, in the form as a nodule.

\section{Summary of Petrologic Analysis}

Boggs (1968) and Slatt and Eyles (1981) stress the importance of using lithic fragments as the best potential indicators of sediment-source information. These fragments are most likely representative of first-cycle parent source, because most rock fragments do not survive recycling as well as individual mineral grains. Hence the high percentages of schist and phyllite lithic grains, and low percentages of rock fragments of 
shale and other sedimentary rocks, within the fluvial sandstones and other upper-deltaplain facies indicate that the source area for the Price sandstones in southern West Virginia was almost entirely metamorphic in nature. Shales and other sedimentary rock fragments were derived locally within the system, typically from the erosion of muddy sedimentary beds. Mechanical breakdown of metamorphic rock fragments increases with greater transport distance as indicated by the decrease in metamorphic rock fragments within the lower-delta-plain facies (Plumley, 1948; Cameron and Blatt, 1971). Smosna and Bruner (1997), in a similar petrographic study, concluded that mineral composition of siliciclasitc sediments is sensitive to depositional environments. Their petrology data indicated that the fluvial sandstone of the Devonian Lock Haven Formation in Pennsylvania are rich in metamorphic rock fragments as well as sedimentary rock fragments. Continuing down the delta plain to the barrier island facies however, percentages of rock fragments decrease by $67 \%$.

Metamorphic rocks are more resistant to mechanical weathering than are sedimentary rock fragments (Plumley, 1948; Boggs, 1968; McBride and Picard, 1987). Some of the resistance of metamorphic fragments, in particular schist grains, can be attributed to the quartz component of the grains. Shale and mudstone grains tend to weather quickly due to the erodabilty of the clay minerals (Folk, 1968). Figure 61 shows the general trend of the type of rock fragments within the facies at Sherwood Lake. In general, as one travels down the delta-plain, the volume of metamorphic rocks decrease as the volume of sedimentary rocks increase. The transition from the fluvial facies to the upper distributary channel facies, however, yields a surprising increase in phyllite volumes, suggesting that phyllite may be slightly more durable than schist grains. Shale 


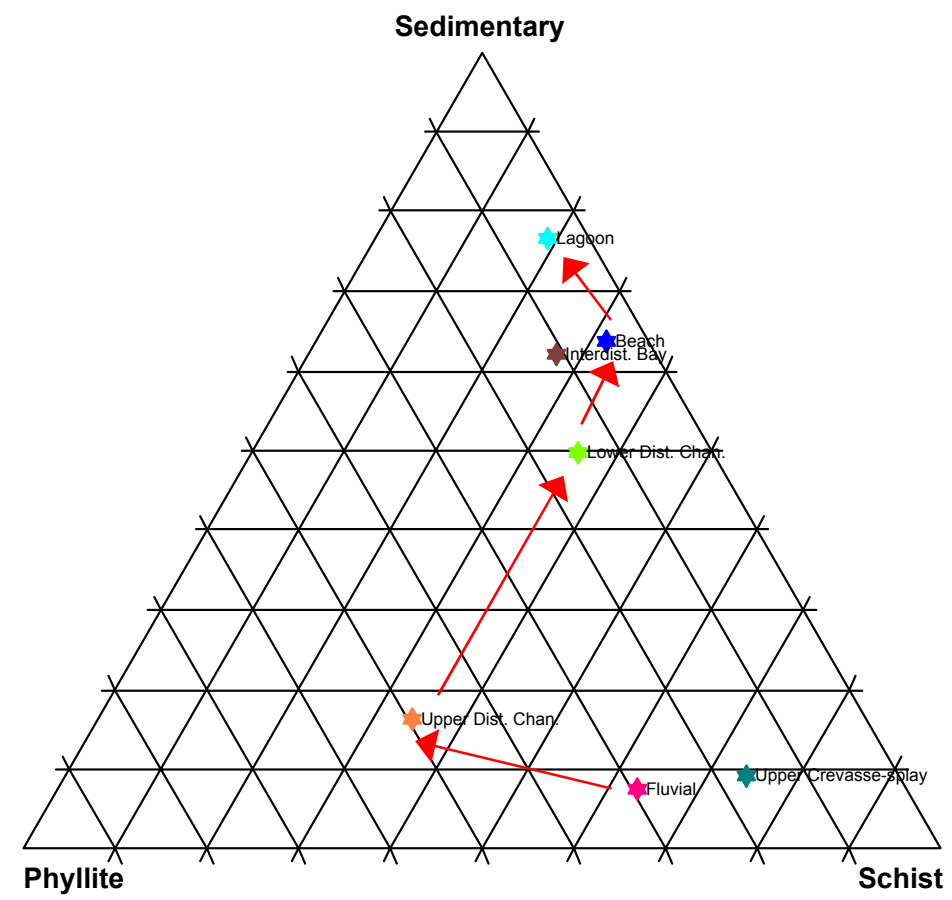

Figure 61: SPS diagram for all 7 facies. Stars indicate the mean lithic percentages for the respective facies. Pink- Fluvial; Orange- upper distributary channels; Dark Greenupper crevasse-splay; Light Green- lower distributary channels; Turquoise- Lagoon; Blue- Beach; Dark Brown- Interdistributary bay. Arrows indicate general down-slope changes in sandstone composition. 
and mudstone rock fragments are more common downstream and towards the bay and lagoon environments. High volumes of sedimentary rock fragments in the lower distributary channels and also in the thalweg of upper-distributary channels located above shale units indicate that these fragments are indeed locally derived from the fine-grained sediments within the system. Extremely high-energy environments, however, produce quartz-rich sediments because all types of rock fragments breakdown in these conditions (Slatt and Eyles, 1981, Garzanti et al. 2002). Higher-energy conditions exist in facies such as the beach, where few rock fragments are present. Within the transgressive lag deposit within the beach facies, rock fragments are also almost entirely absent.

Figure 62 shows the proportion of metamorphic rock fragments relative to quartz grains whereas Figure 63 shows the proportion of shale rock fragments relative to quartz grains for each facies. In these diagrams, quartz was considered to be constant, in the sense that quartz percentages did not vary greatly among all of the facies. Collectively, these figures demonstrate that metamorphic rock fragments do indeed decrease with further distance from the source area, and that shale rock fragments increase further down the delta-plain. Facies on the upper-delta-plain (fluvial, upper distributary channels and crevasse-splays) contain higher proportions of metamorphic rock fragment relative to quartz and lower proportions of shale fragments relative to quartz. Facies on the lowerdelta-plain, beach, lagoon, and interdistributary bays, have significantly lower proportions of metamorphic rock fragments to quartz grains and higher proportions of shale rock fragments to quartz grains. The lower distributary channel facies is indicative of a transition facies and has equal proportions of metamorphic and shale fragments. 


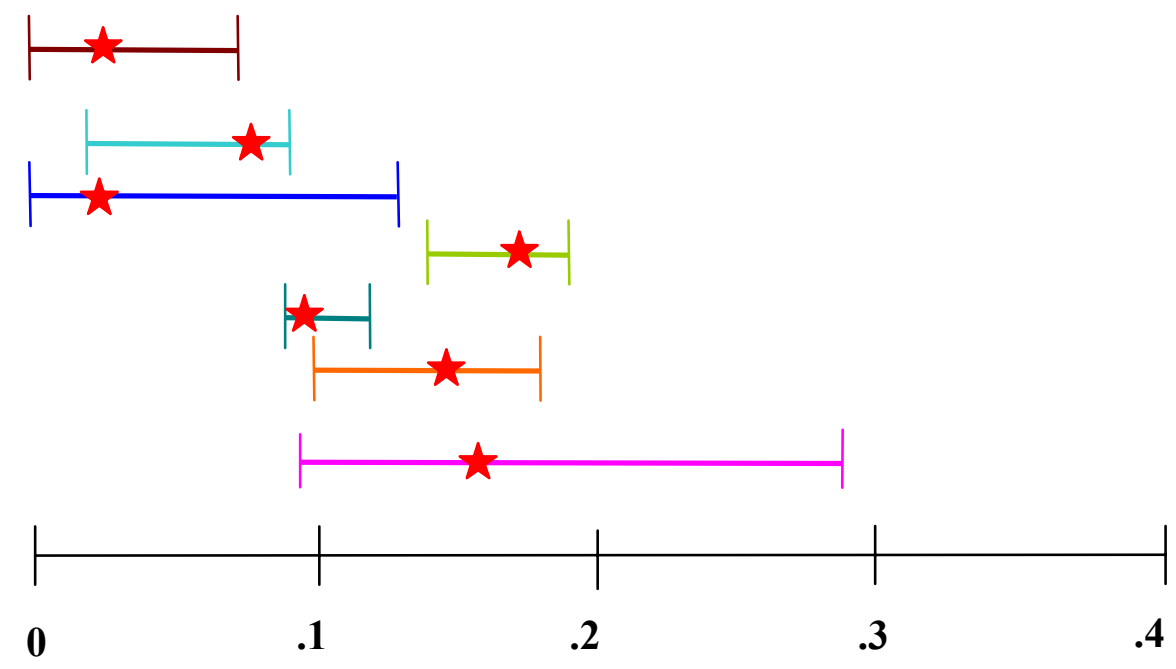

Figure 62: Ratio of total metamorphic rock fragments relative to total quartz for respective facies. Pink- Fluvial; Orange- Upper Distributary Channel; Dark Green- Crevasse-Splay; Light Green- Lower Distributary Channel; Blue- Beach; Turquoise- Lagoon; Brown- Interdistributary Bay. Stars represent mean ratio for each facies, and bars represent the range for the facies.
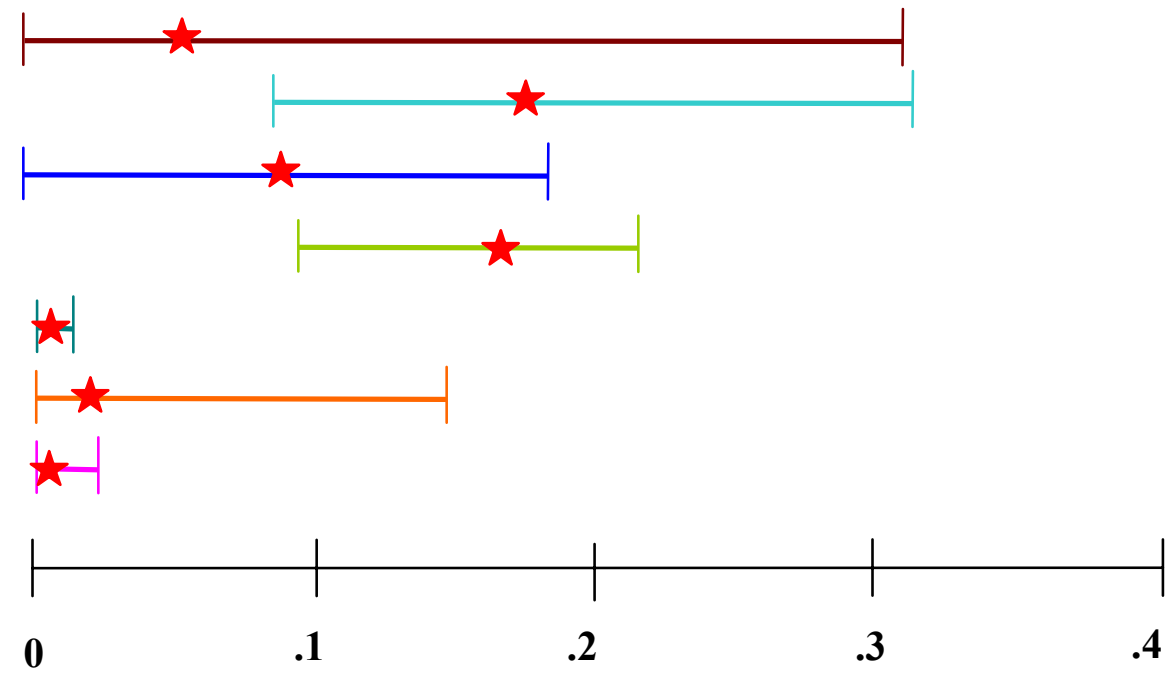

Figure 63: Ratio of shale to quartz for the represented facies, color coordinated same as above. Stars represent the mean ratio for each facies, and bars represent the range for the facies. 
Within the fluvial facies, the lithic component is not necessarily just a factor of the nature of the stream itself, but also a factor of the durability of the grains. At Sherwood Lake, the fluvial facies were deposited within a meandering stream environment. The samples of this facies yield high percentages of schist fragments, moderate amounts of phyllite rock fragments and very few if any percentages of shale rock fragments. The lower proportion of sedimentary rock fragments in river deposits is probably because of the greater susceptibility of sedimentary rock fragments to abrasion (Plumley, 1948; Potter, 1986; Ferree et al., 1988). The high percentages of schist are perhaps because schist may be the most abundant rock in the source area.

The distributary channels located on the lower-delta-plain are probably much smaller and more apt to change their path than are the channels located on the upper plain. Downstream from the upper distributary channels, the lower distributary channels flare out, and the current direction becomes variable and current velocity is reduced; thus the rate of deposition in sediments is increased. This increase in sediment and the decrease in flow regime causes the channels to change paths more frequently than the upper distributary channels (Reineck and Singh, 1980). When the channel changes paths, it usually erodes into the surrounding area, which on the lower delta plain is likely to be interdistributary bays, a lagoon, or a floodplain, all of which have quiet water where mud accumulates. Because of this, more shale lithics are present within the lower-delta-plain distributary channels. Upper distributary channels, by contrast, yield higher volumes of metamorphic rock fragments, specifically phyllite grains. Cameron and Blatt (1971) found that the proportion of schist and other low-grade metamorphic grains decreases rapidly in the downstream direction and concluded that the decrease is due to mechanical 
disaggregation of the metamorphic fragments. Although these metamorphic rock fragments are more resistant to mechanical weathering than sedimentary rocks, they are still relatively mechanically unstable especially in high energy envionments.

Crevasse-splay deposits when plotted on a SPS diagram display a tight grouping with schist being the dominant lithic grain present (Figure 54). These samples are all located on the upper-delta-plain, and are crevasse-splay deposits that occurred adjacent to the upper-delta-plain distributary channels. Most of these distributary channels were rich in metamorphic rock fragments but low in shale abundance, which can account for the large percentages of schist in the crevasse-splay deposits. Schist is probably more abundant due to its resistance to weathering and also because it was present in higher percentages in the adjacent distributary channels. Of more significance, is the small amount of rock fragments present. Crevasse-splay samples have relatively low percentages of rock fragments, with the average being only $8 \%$. Because crevasse-splays form adjacent to distributary channels during high water and high-energy conditions, commonly sorting has occurred by the time the particles reach deposition in a crevassesplay. As a result low percentages of rock fragments are present within the crevasse environment.

The beach-bar facies shows two distinct groups when plotted on an SPS diagram. The majority of samples have sedimentary rock fragments as the dominant grain, and these represent the samples of the shoreface (Figure 56). Shale present in the shoreface indicates that wave action periodically stopped, allowing the muds to settle out of suspension. A change in energy followed and is indicated by mud clasts that are 
incorporated in the sandstones. Also, beach-bar clasts may have been eroded from muds on the offshore sea floor (Reading and Collinson, 1996).

The smaller of the two groups consists of three samples, representative of the foreshore. The foreshore is dominated by wave swash. The uprush of waves onto the beach is generally a constant process, meaning that energy levels within the environment do not change drastically, except during times of storms (Boggs, 1995). The presence of dominantly schist grains in samples $27-01$ and $27-02$ indicates that perhaps schist is more durable than shale, and therefore was more able to withstand the constant swashing of the waves in the area (Garzanti et al., 2002). Also representative of the swash zone is sample 25-06. This sample is somewhat different from the other swash zone samples because in comparison it has a remarkable lack of total lithics. The sample has the highest content of quartz at $93 \%$. In actuality, the sample has only $1 \%$ lithic fragments, which is due to the extremely high energy within the swash zone.

The majority of the rock fragments within the lagoonal sandstone are sedimentary in nature. All three samples within the lagoonal sandstones are representative of the washover environment. The highest percentage of total heavy minerals ( $2.3 \%$ of the total rock constituents) can be found in sample 31-05. Washover deposits typically have a heavy mineral enrichment zone (Reineck and Singh, 1980), which sample 31-05 may be indicative of.

Rock fragments within the interdistributary bay facies compose only an average of $5 \%$ of the total constituents; in most cases shale rock fragments are most abundant. When plotted on a SPS diagram, the interdistributary samples show no grouping, and are the most scattered of all the facies (Figure 60). This is most likely because the source of 
sediment in the interdistributary bays may be derived from multiple areas, therefore influencing the lithologies within the facies. Not only is sediment entering the system via distributary channels, but the nearby beach-bar also is affecting the sediment influx (Smosna and Bruner 1997). Petrographic variation could also be a result of the large percentages of matrix present within the samples, making it difficult to decipher between squashed rock fragments and matrix. Also, a majority of the samples have very few rock fragments total, and on an SPS ternary diagram, variation among samples may not be significant. 


\section{CONCLUSIONS}

The Price Formation in southern West Virginia is composed of interbedded sandstone, siltstone, and mudstone, and is almost entirely Lower Mississippian in age. Three members make up the Price formation in the southern depocenter: the Cloyd Conglomerate Member (oldest), the Sunbury Shale Member, and an undifferentiatied upper member (youngest). These rocks are best exposed at the principle reference section, which is along the I-64 road cut near Caldwell, West Virginia in Greenbrier County. For this thesis however, six sections of the upper Price member near Sherwood Lake were measured and described so that a depositional model could be reconstructed. The upper Price in general preserves a wide spectrum of environments. The Sherwood Lake composite sections, display a shallowing upward sequence of environments from the lower delta plain to fluvial. This sequence displays a succession that can be compared to published standard prograding deltaic and other facies models. Seven facies are present: fluvial, distributary channel, crevasse-splay, interdistributary bay, interdistributary bay swamp, lagoon, and beach-bar.

Rocks indicative of the fluvial facies were deposited in a meandering river and are present as multistory sandbodies. Distributary channel facies yield successions that begin with scoured basal contacts and lags that grade upward to fine to medium-grained sandstones with large-scale planar and trough cross-beds. Upper-delta-plain distributary channels exhibit rocks with scour-and-fill structure, and commonly lack the entire finingupward sequence. Channels located on the lower-delta-plain, however, show less scourand-fill, but more of the entire fining-upward sequence present in ideal distributary channel sequences (Figure 22). Crevasse-splay deposits tend to be relatively thin (1 
meter or less) and characteristically have a scoured basal contact with shale and/or coal clasts lags or a quartz pebble conglomerate lag that fines upward to fine-grained sandstone. Interdistributary bays are sequences of rock that have an irregular pattern of sandstone, siltstone, and mudstone interbeds. With the exception of both large and smallscale ripples, sedimentary structures are typically lacking within the facies.

Interdistributary swamps are characterized by their coal deposits. Lagoonal deposits are very fine-grained sand and mud deposits that exhibit laminar or very thin bedding, sometimes with starved ripples. Beach-bar deposits consist of fine-grained sandstone with many shale parting and minor scoured surfaces.

Each facies was sampled for petrographic analysis and percentages of various minerals were used in order to construct ternary diagrams. QFL diagrams show little variation among facies, but indicate that most of the samples can be classified as sublitharenites, with a few samples being quartzarenites and litharenites. Lithic ternary diagrams, which plot grains of sedimentary rocks, phyllite and schist rock fragments (SPS), show the best variation among facies, and also the best grouping within a single facies. It was found that facies located on the upper-delta-plain have higher percentages of metamorphic rocks fragments, while facies located on the lower-delta-plain have higher percentages of sedimentary rock fragments.

High percentages of metamorphic rock fragments and low percentages of sedimentary rock fragments in the fluvial and upper-distributary channel facies indicates that the source area for the Price Formation at Sherwood Lake was almost entirely metamorphic in nature. Sedimentary rock fragments were most likely locally derived from within the system. Although schist and phyllite rock fragments are more resistant 
to mechanical weathering than are sedimentary rock fragments, the decrease of metamorphic rock fragment percentages in the lower-delta-plain facies indicates that these fragments were by no means resistant to erosion and hence are mechanically unstable. Energy within the facies also has an effect on the rock fragments present, and typically affects the amount of rock fragments present within that environment. Higher energy facies such the beach-bar have considerably less rock fragments than those facies indicative of moderate and low energy systems.

When plotted on SPS diagrams tight grouping occurs in all facies except for the interdistributary bay facies. This is most like because the sediment influx is derived from both the distributary channels as well as the beach-bar. In most other facies, sediment influx is either fluvial or tidal in origin, but not both simultaneously. 


\section{REFERENCES}

Bhattacharya, J.P. and R.G. Walker, 1992. Deltas. In R.G. Walker and N.P. James (eds.) Facies Models, Response to Sea Level Change. Geological Association of Canada, St. Johns, New Foundland.

Bjerstedt, T.W., 1986. Stratigraphy and deltaic depositional systems of the Price Formation (Upper Devonian-Lower Mississippian) in West Virginia. Unpublished Ph.D. Dissertation, West Virginia University, Morgantown, WV. 730 .

Bjerstedt, T.W. and T.W. Kammer, 1988. Genetic stratigraphy and depositional systems of the Upper Devonian-Lower Mississippian Price-Rockwell deltaic complex in the central Appalachians, USA. Sedimentary Geology. 54:265-301.

Boggs, S. Jr., 1968. Experimental study of rock fragments. Journal of Sedimentary Petrology. 38:1326-1339.

Boggs, S., Jr., 1995. Principles of Sedimentology and Stratigraphy. Prentice-Hall, Inc. Upper Saddle River, New Jersey.

Boswell, R., 1985. Stratigraphy and sedimentation of the Acadian clastic wedge in northern West Virginia. Unpublished Master's Thesis. West Virginia University, Morgantown, WV. 179.

Boswell, R. M., 1988. Basin Analysis of the Acadian Clastic Wedge in northern West Virginia. Unpublished Ph.D. Dissertaion. West Virginia University, Morgantown, WV. 349.

Butts, C., 1940. Geology of the Appalachian valley in Virginia. Virginia Geological Survey, Bulletin 52, Part 1, 568.

Cameron, K.L. and H. Blatt, 1971. Durabilities of sand size schist and "volcanic" rock fragments during fluvial transport, Elk Creek, Black Hills, South Dakota. Journal of Sedimentary Petrology, 41:565-576.

Cant, D.J., 1982. Fluvial facies models and their application. In Woodward, Howell, Beaumont, Hart, and White (eds.) Sandstone Depositional Environments. American Association of Petroleum Geologists, Memoir, 31. pp.115-137.

Carter J.L. and T.W. Kammer, 1990. Late Devonian and Early Carboniferous brachiopods (Brachiopoda, Articulata) fron the Price Formation of West Virginia and adjacent areas of Pennsylvania and Maryland. Annals of Carnegie Museum. 59:77-103. 
Coleman, J.M. and D.B. Prior, 1982. Deltaic environments. In Woodward, Howell, Beaumont, Hart, and White (eds.) Sandstone Depositional Environments. American Association of Petroleum Geologists, Memoir, 31. pp. 139-178.

Collinson, J.D., 1996. Alluvial sediments. In Reading, H.G. (ed.) Sedimentary Environments: Processes, Facies, and Stratigraphy. Blackwell Science Ltd, Oxford, England. p. 37-83.

Craig, L.C. and C.W. Connor (eds.), 1979. Paleotectonic investigations of the Mississippian System in the United States. U.S. Geological Survey Professional Paper 1010.

Dally, J.E., 1955. Stratigraphy and paleontology of the Pocono Formation in West Virginia. Unpublished Ph.D. Dissertation, Columbia University, N.Y. 241.

Dennison, J.M., 1970. Stratigraphic divisions of Upper Devonian Greenland Gap Group ("Chemung Formation") along the Allegheny Front in West Virginia, Maryland, and Highland County Virginia. Southeastern Geology, 12:53-82.

Dennison, J.M. and W.H. Wheeler, 1975. Stratigraphy of PreCambrian through Cretaceous strata of porbable fluvial origin in southeastern United States and their potential as uranium source rocks. Southeastern Geology, Special Publication 5. 210.

Donaldson, A. C. and R.C. Shumaker, 1981. Late Paleozoic molasse of central Appalachians, pp. 100-123, In Miall, A.D. (ed.), Sedimentation and tectonics in alluvial basins. Geological Association of Canada, Special Paper 23.

Ettensohn, F.R., 1985. The Catskill delta complex and the Acadian orogeny: a model. In Woodrow and Seven (eds.) The Catskill Delta. Geological Society of America Special Paper 201. p. 39-49.

Ferree, R.A., D.W. Jordan, R.S. Kertes, K.M. Savage, and P.E. Potter, 1988.

Comparative petrographic maturity of river and beach sand, and origin of quartz arenites. Journal of Geological Education, 36:79-87.

Fichter, L.S., 1986. The Catskill clastic wedge (Acadian Orogeny) in eastern West Virginia. In Neathery, T.L. (ed.) Geological Society of America Centennial Field Guide-Southeastern Section.

Folk, R.L., 1968. Petrology of sedimentary rocks. Hemphill Publishing Company, Austin, TX. 170.

Garzanti, E., S. Canclini, F.M. Foggia and N. Pertella, 2002. Unraveling magmatic and orogenic porvenance in modern sand: the back-arc side of the Apennine thrust belt, Italy. Journal of Sedimentary Research, 72:2-17. 
Hohn, M.Ed., R.R. McDowell, D.L. Matchen, and A.G. Vargo, 1997. Heterogeneity of fluvial-deltaic reservoirs in the Appalachian basin: a case study from a Lower Mississippian oil field in central West Virginia. AAPG Bulletin. 81:918-936.

Kammer, T.W. and T.W. Bjerstedt, 1986. Stratigraphic framework of the Price Formation (Upper Devonian-Lower Mississippian) in West Virginia. Southeastern Geology. 27:13-33.

Kreisa, R. D. and R. K. Bambach, 1973. Environments of deposition of the Price Formation (Lower Mississippian) in its type area, southwest Virginia. American Journal of Science, Cooper Memorial Volume. 273A:326-342.

Mann, D. A., 1998. The Price Formation of northeastern West Virginia and western Maryland: a sedimentary and petrologic analysis. Unpublished Masters Thesis, West Virginia University, Morgantown, WV. 161.

Matchen, D.L., 1992. Sequence stratigraphy of the Lower Mississippian clastic wedge in West Virginia and Kentucky. Unpublished Masters Thesis, West Virginia University, Morgantown, WV. 177.

Matchen, D.L., and T.W. Kammer, 1994. Sequence Stratigraphy of the Lower Mississippian Price and Borden Formations in southern West Virginia and eastern Kentucky. Southeastern Geology. 34:25-41.

McBride, E.F. and M.D. Picard, 1987. Downstream changes in sand composition, roundness, and gravel size in a short-headed, high-gradient stream, northwestern Italy. Journal of Sedimentary Petrology, 57:1018-1026.

Miall, A.D., 1992. Alluvial deposits In R.G. Walker and N.P. James (eds.) Facies Models, Response to Sea Level Change. Geological Association of Canada, St. Johns, New Foundland.

Orton, G.J., and H.G. Reading, 1993. Variability of deltaic processes in terms of sediment supply, with particular emphasis on grain size. Sedimentology, 40:475512.

Pelletier, B.R., 1958. Pocono paleocurrents in Pennsylvania and Maryland. Geological Society of America Bulletin, 69:1033-1063.

Plumney, W.J., 1948. Black Hills terrace gravels: a study in sediment trasport. Journal of Geology, 56:526-577.

Potter, P.E., 1978. Petrology and chemisty of modern big river sands. Journal of Geology, 86:423-449. 
Prothero, D.R., 1990. Interpreting the Stratigraphic Record. W.H. Freeman and Company, New York, NY.

Raymond, L.A., 1995. Petrology: the study of igneous, sedimentary, and metamorphic rocks. WCB McGraw Hill, Boston, MA. 742.

Reading, H.G. and J.D. Collinson, 1996. Clastic coasts. In Reading, H.G. (ed.) Sedimentary Environments: Processes, Facies, and Stratigraphy. Blackwell Science Ltd, Oxford. p. 154-232.

Reineck, H.E. and I.B. Singh, 1980. Depositional Sedimentary Environments. Springer-Verlag, New York, NY.

Ross, C. A., and J. R. Ross, 1985. Late Paleozoic depositional sequences are synchronous and worldwide. Geology. 13:194-197.

Scholle, P.A., 1979. A color illustrated guide to constituents, textures, cements, and porosities of sandstones and associated rocks. Association of Petroleum Geologists, Memoir, 28. 201.

Smosna, R. and K.R. Brunner, 1997. Depositional controls over porosity development in lithic sandstones of the Appalachian Basin: reducing exploration risk. AAPG Memoir, 69:249-265.

Slatt, R.M. and N. Eyles, 1981. Petrology of glacial sand: implication for the origin and mechanical durability of lithic fragments. Sedimentology, 28:171-183.

Van Gelder, A., J.H. van den Berg, G. Cheng, and C. Xue, 1994. Overbank and channel fill deposits of the modern Yellow River delta. Sedimentary Geology, 90:293-305. 


\section{APPENDIX A}

Measured Sections at Sherwood Lake 


\section{$\underline{\text { Unit Descriptions }}$}

OUTCROP $1-8.24$ m exposed. County Route 14-1 (Sherwood Lake Rd.), 0.9 m from Rucker Gap Road, Greenbrier Co., W.V.

\section{UNIT 1}

Thickness $-1.4 \mathrm{~m}$

Rock Name - Fine/Very fine-grained sandstone

Color - Weathers brown; fresh gray-green.

Bedding Characteristics -2 beds, medium to thick

Sedimentary Structures - Horizontal bedding; fines upward; sharp basal contact

Fossils - None

Samples Collected $-01-01 ; \underline{01-02}$

\section{UNIT 2}

Thickness - .86 m

Rock Name - Siltstone dominant $(.50 \mathrm{~m})$; interbedded mudstone $(.36 \mathrm{~m})$

Color - Weathers rusty brown; fresh dark gray

Bedding Characteristics - Laminated, very thin

Sedimentary Structures - Small-scale wave ripples

Fossils - None

Samples Collected - None

\section{UNIT 3}

Thickness - .24 m

Rock Name - Fine-grained sandy siltstone

Color - Weathers light gray; fresh dark gray

Bedding Characteristics - Massive

Sedimentary Structures - None

Fossils - None

Samples Collected - None

\section{UNIT 4}

Thickness $-.34 \mathrm{~m}$

Rock Name - Mudstone grading upward to shale

Color - Weathers redish; fresh dark gray to black

Bedding Characteristics - Very thin to laminated

Sedimentary Structures - None

Fossils - None

Samples Collected - None

\section{UNIT 5}

Thickness $-1.2 \mathrm{~m}$

Rock Name - Siltstone/very fine-grained sandstone

Color - Weathers browning gray; fresh dark gray

Bedding Characteristics - Thin to medium

Sedimentary Structures - Wavy basal contact, horizontal bedding 
Fossils - None

Samples Collected - None

\section{UNIT 6}

Thickness - varies laterally between $.3-1.0 \mathrm{~m}$

Rock Name - Coarse to medium-grained sandstone

Color - Weathers brown; fresh gray to light gray

Bedding Characteristics - Thick

Sedimentary Structures - Scoured basal contact; small scale planar crossbeds

Fossils - None

Samples Collected - 06-01; 06-02; 06-03

\section{UNIT 7}

Thickness - Varies laterally between $.2-.5 \mathrm{~m}$

Rock Name - Pebble Conglomerate; quartz grains and siderite nodules most common, average grain size $2 \mathrm{~cm}$

Color - Weathers brownish gray; fresh dark gray

Bedding Characteristics - Massive

Sedimentary Structures - Scoured basal contact, some pebble imbrication

Fossils - None

Samples Collected - $\underline{07-01} ; \underline{07-02} ; \underline{07-03} ; \underline{07-04}$

\section{UNIT 8}

Thickness $-2.35 \mathrm{~m}$

Rock Name - Mudstone with interbeds of fine-grained sandstone

Color - Weathers brown; fresh brownish-black

Bedding Characteristics - very thin to thin, medium at some places

Sedimentary Structures - sandstone interbeds are discontinuous and lenzoid, flat bedded; starved mega ripples

Fossils - None

Samples Collected $-\underline{08-01}$

\section{UNIT 9}

Thickness - Varies laterally between $0-.35 \mathrm{~m}$

Rock Name - Fine-grained sandstone

Color - Weathers brown; fresh dark gray

Bedding Characteristics - Thick

Sedimentary Structures - Small-scale planar cross-beds; lenticular bedding Fossils - None

Samples Collected - None 
OUTCROP 2 - 10.36 m exposed. County Route 14-1 (Sherwood Lake Rd.), approximately $.2 \mathrm{~m}$ northeast of outcrop 1 .Outcrop 2 is a repeated section of outcrop 1 . Because outcrop 2 is larger, better exposed, and more accessible, the unit numbers for outcrop 2 are referred to more in text. The correlative equivalents of outcrop 1 are listed next to the unit numbers for outcrop 2.

\section{UNIT 10 (Unit 1)}

Thickness $-1.1 \mathrm{~m}$, minimum thickness, unit partly covered

Rock Name - Silty fine-grained sandstone grading upward to interbedded siltstone and mudstone

Color - Weathers brown gray, fresh light gray

Bedding Characteristics - Thin to medium

Sedimentary Structures - Small-scale planar cross-beds

Fossils - None

Samples collected $-\underline{10-01} ; \underline{10-02}$

\section{UNIT 11 (Unit 2)}

Thickness - .72 m

Rock Name - Fine-grained sandstone grading upward to mudstone

Color - Weathers brown, fresh gray

Bedding Characteristics - Thick to massive

Sedimentary Structures - None

Fossils - None

Samples Collected $-\underline{11-01}$

\section{UNIT 12 (Units 3)}

Thickness - .84 m

Rock Name - Interbedded fine-grained sandstone and siltstone

Color - Weathers red-brown, fresh gray

Bedding Characteristics - Thin to medium, some beds with shallow basal scours

Sedimentary Structures - Wavy basal contact, small-scale planar cross-beds

Fossils - None

Samples Collected - $\underline{12-01} ; \underline{12-02} ; \underline{12-03} ; \underline{12-04}$

\section{UNIT 13 (Unit 4)}

Thickness - .65 m

Rock Name - Mudstone

Color - Weathers black, fresh light gray

Bedding Characteristics - Laminated

Sedimentary Structures - Starved ripples; siderite nodules

Fossils - None

Samples Collected - None

\section{UNIT 14 (Unit 5)}

Thickness $-1.18 \mathrm{~m}$

Rock Name - Siltstone coarsening upward to fine-grained sandstone

Color - Weathers brown, fresh gray

Bedding Characteristics - Medium to thick

Sedimentary Structures - Small-scale trough cross-beds and scour surfaces 
Fossils - None

Samples Collected $-\underline{14-01}$

UNIT 15 (Unit 5)

Thickness - Varies laterally between $0-.44 \mathrm{~m}$

Rock Name - Mudstone grading upwards to shale

Color - Weathers gray, fresh black

Bedding Characteristics - Very thin to laminated

Sedimentary Structures - Where present extremely scoured by upper unit

Fossils - None

Samples Collected - None

\section{UNIT 16 (Unit 6)}

Thickness - Varies laterally between $0-1.67 \mathrm{~m}$

Rock Name - Medium-grained sandstone

Color - Weathers brown-red; fresh red-gray

Bedding Characteristics - Massive

Sedimentary Structures - Scoured basal contact; scour and fill bedding

Fossils - None

Samples Collected - None, due to inaccessibility

UNIT 17 (not present, probably due to erosion by unit 7)

Thickness - Varies laterally between $0-.16 \mathrm{~m}$

Rock Name - Shale

Color - Weathers dark gray, fresh black

Bedding Characteristics - Laminated

Sedimentary Structures - wavy/scoured basal contact

Fossils - None

Samples collected - None

\section{UNIT 18 (Unit 7)}

Thickness - .30 m

Rock Name - Pebble Conglomerate; quartz grains and siderite nodules most common, average grain size $1 \mathrm{~cm}$

Color - Weathers brown; fresh reddish brown

Bedding Characteristics - Medium

Sedimentary Structures - Scoured basal contact

Fossils - None

Samples Collected $-\underline{18-01}$

\section{UNIT 19 (Units 8 and 9)}

Thickness $-3.3 \mathrm{~m}$

Rock Name - Interbedded siltstone and fine-grained sandstone

Color - Weathers brown, fresh gray

Bedding Characteristics - Medium to thick

Sedimentary structures - Wavy bedding

Fossils - None

Samples Collected - None, due to inaccessibility 
OUTCROP 3- 2.78 m exposed County Route 14-1 (Sherwood Lake Rd.), approximately .2 miles northeast of outcrop 2. Outcrop 3 is a repeated section of outcrops 1 and 2, but exposes only the last few meters of the upper units in each outcrop (units 8, 9 and 19). The correlative equivalents of outcrops 1 and 2 are listed next to the unit numbers for outcrop 3.

\section{UNIT 20 (Units 8 and 19)}

Thickness -Partially covered, minimum thickness of .40 m

Rock Name - Interbedded siltstone and fine-grained sandstone

Color - Weathers light brownish gray, fresh gray

Bedding Characteristics - Thin

Sedimentary Structures - None

Fossils - None

Samples Collected - 20-01

UNIT 21 (Units 8 and 19)

Thickness $-.85 \mathrm{~m}$

Rock Name - Interbedded mudstone and siltstone

Color - Weathers brownish gray, fresh light gray

Bedding Characteristics - Thick

Sedimentary Structures - None

Fossils- None

Samples Collected - None

UNIT 22 (Units 8, 9, and 19)

Thickness - .52 m

Rock Name - Interbedded mudstone and siltstone

Color - Weathers greenish gray, fresh light gray blue

Bedding Characteristics - Appears thick to medium, but breaks thin

Sedimentary Structures - None

Fossils - None

Samples Collected $-\underline{22-01}$

UNIT 23 (Units 8, 9, and 19)

Thickness $-1.01 \mathrm{~m}$

Rock Name - Interbedded mudstone and siltstone

Color - Weathers blue-gray, fresh light gray

Bedding Characteristics - Thin to medium

Sedimentary Structures - Siderite nodules

Fossils - None

Samples Collected - None 
OUTCROP 4-21.05 m exposed. County Route 14-1 (Sherwood Lake Rd.), approximately .6 miles northeast of outcrop 3 .

\section{UNIT 24}

Thickness - Partially covered, minimum thickness of $1.12 \mathrm{~m}$

Rock Name - Pebble conglomerate lag; quartz grains and siderite nodules most common, average grain size $1 \mathrm{~cm}$

Color - Weathers red, fresh reddish brown

Bedding Characteristics - Thick

Sedimentary Structures - Coarsens upwards to hand size grains; sandstone lenses within conglomerate

Fossils - unidentifiable broken and highly replaced shell material. Gastropods Samples Collected - 24-01; 24-02

** This unit is a transgressive lag conglomerate that corresponds with T-4, as identified by Bjerstedt (1986) and Kammer and Bjerstedt (1988).

\section{UNIT 25}

Thickness - Partially covered, minimum thickness of .92 m

Rock Name - Medium to fine-grained sandstone

Color - Weathers brown/brick red, fresh purple/gray

Bedding Characteristics - Thick to massive

Sedimentary Structures - Large-scale planar cross-beds; wave ripples; graded bedding; scoured basal contact

Fossils - None

Samples Collected - 25-01; 25-02; 25-04; 25-03; 25-05; $\underline{25-06}$

\section{UNIT 26}

Thickness $-3.8 \mathrm{~m}$

Rock Name - Fine to medium-grained sandstone with many shale partings and clasts

Color - Weathers light brown, fresh grade

Bedding Characteristics - Thin to medium

Sedimentary Structures - Large-scale planar cross-bed at base of unit, fines up to smallscale planar cross-beds in the middle of the unit, fines further to starved ripples; flaser bedding, ripple marks, frequent scoured surfaces.

Fossils - None

Samples Collected - 26-01; 26-02; 26-03; 26-04; 26-05; 26-06; 26-07; 26-08; 26-09; 26$\underline{10} ; 26-11 ; \underline{26-12}$

\section{UNIT 27}

Thickness $-3.3 \mathrm{~m}$

Rock Name - Fine to medium-grained sandstone grading upward to coarse-grained sandstone

Color - Weathers dark gray; fresh light to medium gray

Bedding Characteristic - Medium bedded

Sedimentary Structures - Some shale partings and scoured surfaces; shale clasts

Fossils - None

Samples Collected $-\underline{27-01} ; \underline{27-02}$ 


\section{UNIT 28}

Thickness $-1.61 \mathrm{~m}$

Rock Name - Interbedded shale and minor fine-grained sandstone beds

Color - Weathers deep brown, fresh black

Bedding Characteristics - Very thin to laminated

Sedimentary Structures - Starved ripples in lower part of unit; wavy bedding towards top of unit; siderite nodules; abrupt basal contact, sandstone lenses

Fossils - None contain many shale rip-up clasts

Samples Collected - None

\section{UNIT 29}

Thickness $-1.92 \mathrm{~m}$

Rock Name - Interbedded fine-grained sandstone and siltstone

Color - Weathers light brown, fresh medium gray

Bedding Characteristics - Appears thick, but weathers thin

Sedimentary structures - None

Fossils - None

Samples Collected $-\underline{29-01}$

\section{UNIT 30}

Thickness - .7 m

Rock Name - Black Shale

Color - Weathers brown-black, fresh black

Bedding Characteristics - laminated, fissile

Sedimentary Structures - None

Fossils- None

Samples Collected - None

\section{UNIT 31}

Thickness $-1.6 \mathrm{~m}$

Rock Name - Interbeds of fine-grained sandstone and sandy shale/siltstone

Color - Weathers brown-black, fresh medium gray

Bedding Characteristics - Laminated

Sedimentary Structures - Wavy bedding

Fossils - None

Samples Collected - 31-01; 31-02; 31-03; 31-04; $\underline{31-05}$

\section{UNIT 32}

Thickness $-3.38 \mathrm{~m}$

Rock Name - Medium-grained sandstone

Color - Weathers brown-gray, fresh light gray

Bedding Characteristics - Appears massive, but medium to thin bedded

Sedimentary Structures - Scoured basal surface, rippled upper surface, basal conglomerate, large- scale planar cross-beds in at least two

Fossils - None directions, wavy bedding near top of unit

Samples Collected - 31-01; 31-02; 31-03; 31-04; $\underline{31-05}$ 


\section{UNIT 33}

Thickness - .8 m

Rock Name - Shale

Color - Weathers brown, fresh dark brown-black

Bedding Characteristics - Laminated; platy

Sedimentary Structures - None

Fossils - None

Samples Collected - None

\section{UNIT 34}

Thickness $-1.9 \mathrm{~m}$

Rock Name - Fine-grained sandstone

Color - Weathers brown, fresh blue-gray

Bedding Characteristics - Thick

Sedimentary Structures - Scoured basal contact; large-scale trough cross-beds

Fossils - None

Samples Collected - $\underline{34-01 ; 34-02}$ 
OUTCROP 5 - 12.12 m exposed. Route 14-1 (Sherwood Lake Rd.), approximately .4 miles northeast of outcrop 4.

\section{UNIT 35}

Thickness - Partially covered, minimum thickness of .4 m

Rock Name - Coal

Color - Weathers charcoal gray, fresh black

Bedding Characteristics - Very thin and platy

Sedimentary Structures - Red-orange films present on bedding planes; scoured top surface

Fossils - None

Samples Collected - 35-01

\section{UNIT 36}

Thickness $-1.12 \mathrm{~m}$

Rock Name - Fine to medium-grained sandstone

Color - Weathers bright red-orange, fresh beige

Bedding Characteristics - Thin, medium, and thick

Sedimentary Structures - Scoured basal contact; basal sandstone extremely dirty, with

Fossils - None

coal and shale rip-up clasts; load structures; small trace fossils

Samples Collected - $\underline{36-01} ; \underline{36-02} ; \underline{36-03} ; 36-04 ; 36-01 ; 36-02 ; 502-03 ; 36-04 ; 36-05$; 36-06

\section{UNIT 37}

Thickness $-.4 \mathrm{~m}$

Rock Name - Extremely weathered fine grained sandstone

Color - Black

Bedding Characteristics - Very thin to thin; weathers blocky

Sedimentary Structures - Large coal clasts, siderite nodules, yellow film on bedding planes

Fossils - None

Samples collected - 37-01

\section{UNIT 38}

Thickness - $10.2 \mathrm{~m}$

Rock Name - Medium grained-sandstone

Color - Weathers whitish orange, fresh light orange-gray

Bedding characteristics - Thin bedded at base, thick to massive bedding near the middle, thick to medium at top

Sedimentary Structures - Large-scale planar and trough cross-beds; many individual channel scours cutting into one another, an average size of $2.5 \mathrm{~m}$

Fossils - None in height by $5 \mathrm{~m}$ in width; minor shale pebbles at base

Samples Collected - $\underline{38-01} ; \underline{38-02} ; \underline{38-03} ; \underline{38-04} ; \underline{38-05} ; \underline{38-06} ; \underline{38-07} ; \underline{38-08} ; \underline{38-09} ; \underline{38-}$ 
OUTCROP 6 - 9.8 m exposed. Route 14-1 (Sherwood Lake Rd.), approximately .5 miles northeast of outcrop 5.

\section{UNIT 39}

Thickness $-9.8 \mathrm{~m}$

Rock Name - Medium grained-sandstone

Color - Weathers brown-gray, fresh beige

Bedding Characteristics - Highly variable from thin to very thick

Sedimentary Structures - Large-scale planar and scour and fill cross-beds; individual channels scour into each other multiple times; average channel

Fossils - None systems are $1 \mathrm{~m}$ in height and $6 \mathrm{~m}$ in width

Samples Collected - $\underline{39-01} ; \underline{39-02} ; \underline{39-03} ; \underline{39-05} ; \underline{39-06} ; \underline{39-07} ; \underline{39-08} ; 39-09 ; 39-10 ; 39-$ $11 ; 39-12 ; \underline{39-13}$ 
APPENDIX B

Point-Count Data 
Total Percentage of All Constituents

\begin{tabular}{|c|c|c|c|c|c|c|c|c|c|c|c|c|c|}
\hline & \multicolumn{4}{|c|}{ Quartz } & & \multicolumn{3}{|c|}{ Feldspar } & \multicolumn{5}{|c|}{ Rock Frags } \\
\hline Sample & Norm & Und & Poly & Cht & Total Q & Plag & K-spar & Total Feld & Sh & Phyl & Sch & Oth & Total Rx \\
\hline $39-08$ & 37.0 & 31.0 & 11.3 & 0.7 & 80.0 & 1.0 & 0.0 & 1.0 & 0.3 & 4.3 & 6.0 & 0.0 & 10.7 \\
\hline $39-13$ & 29.7 & 35.3 & 12.3 & 0.3 & 77.7 & 1.0 & 1.0 & 2.0 & 1.3 & 3.3 & 7.0 & 0.0 & 11.7 \\
\hline $39-05$ & 28.7 & 25.7 & 16.3 & 2.0 & 72.7 & 0.7 & 0.7 & 1.3 & 1.3 & 4.3 & 10.3 & 0.0 & $\overline{16.0}$ \\
\hline 39-02 & 27.3 & 23.0 & 13.7 & 1.0 & 65.0 & 1.7 & 0.7 & 2.3 & 1.7 & 3.3 & 15.0 & 0.0 & 20.0 \\
\hline 39-01 & 36.0 & 31.3 & 12.7 & 1.0 & 81.0 & 0.0 & 0.3 & 0.3 & 0.3 & 2.3 & 10.0 & 0.0 & 12.7 \\
\hline $39-07$ & 32.7 & 31.0 & 11.7 & 0.7 & 76.0 & 0.7 & 1.0 & 1.7 & 1.3 & 3.0 & 8.0 & 0.0 & 12.3 \\
\hline $39-03$ & 34.3 & 29.3 & 8.0 & 0.7 & 72.3 & 0.3 & 0.3 & 0.7 & 1.0 & 3.0 & 5.3 & 0.0 & $\overline{9.3}$ \\
\hline $39-06$ & 40.3 & 26.7 & 7.7 & 0.3 & 75.0 & 0.3 & 0.0 & 0.3 & 0.3 & 3.0 & 3.0 & 0.0 & 6.3 \\
\hline averages & 33.3 & 29.2 & 11.7 & 0.8 & 75.0 & 0.7 & 0.5 & 1.2 & 1.0 & 3.3 & 8.1 & 0.0 & $\overline{12.4}$ \\
\hline $38-10$ & 44.7 & 18.0 & 12.0 & 1.7 & 76.3 & 2.3 & 1.3 & 3.7 & 1.0 & 7.3 & 3.3 & 0.0 & 11.7 \\
\hline $38-01$ & 37.3 & 17.3 & 11.3 & 1.0 & 67.0 & 0.3 & 0.7 & 1.0 & 10.0 & 5.7 & 3.3 & 0.0 & 19.0 \\
\hline $38-04$ & 36.3 & 27.0 & 10.0 & 1.0 & $\begin{array}{l}74.3 \\
\end{array}$ & 0.0 & 0.0 & 0.0 & 1.0 & 7.3 & 4.3 & 0.0 & 12.7 \\
\hline $38-05$ & 45.7 & 22.7 & 10.3 & 1.0 & $\begin{array}{l}79.7 \\
\end{array}$ & 0.3 & 0.0 & 0.3 & 1.0 & 5.7 & 3.3 & 0.0 & 10.0 \\
\hline $38-08$ & 34.3 & 29.0 & 10.0 & 0.7 & 74.0 & 0.3 & 0.0 & 0.3 & 1.7 & 8.0 & 3.7 & 0.0 & 13.3 \\
\hline $38-06$ & 37.7 & 27.0 & 9.0 & 0.7 & 74.3 & 1.7 & 0.3 & 2.0 & 1.7 & 8.0 & 4.3 & 0.0 & 14.0 \\
\hline $38-07$ & 33.0 & 29.0 & 14.7 & 0.3 & 77.0 & 0.7 & 0.3 & 1.0 & 1.7 & 3.7 & 4.3 & 0.0 & 9.7 \\
\hline 38-02 & 39.0 & 21.3 & 12.3 & 0.3 & 73.0 & 0.0 & 0.3 & 0.3 & 0.7 & 4.3 & 3.7 & 0.0 & 8.7 \\
\hline $38-03$ & 34.3 & 22.0 & 8.0 & 0.3 & 64.7 & 0.3 & 0.3 & 0.7 & 5.0 & 6.0 & 4.0 & 0.0 & 15.0 \\
\hline $38-09$ & 36.7 & 25.3 & 13.0 & 1.3 & $\begin{array}{l}76.3 \\
\end{array}$ & 0.3 & 0.0 & 0.3 & 0.3 & 5.3 & 7.3 & 0.0 & 13.0 \\
\hline averages & 37.9 & 23.9 & 11.1 & 0.8 & 73.7 & 0.6 & 0.3 & 1.0 & 2.4 & 6.1 & 4.2 & 0.0 & 12.7 \\
\hline
\end{tabular}

Fluvial Crevasse-splay Interdistributary Bay Lagoon $\quad$ Upper Distributary Channel $\quad$ Lower Distributary Channel Beach-Bar 
Total Percentage of All Constituents

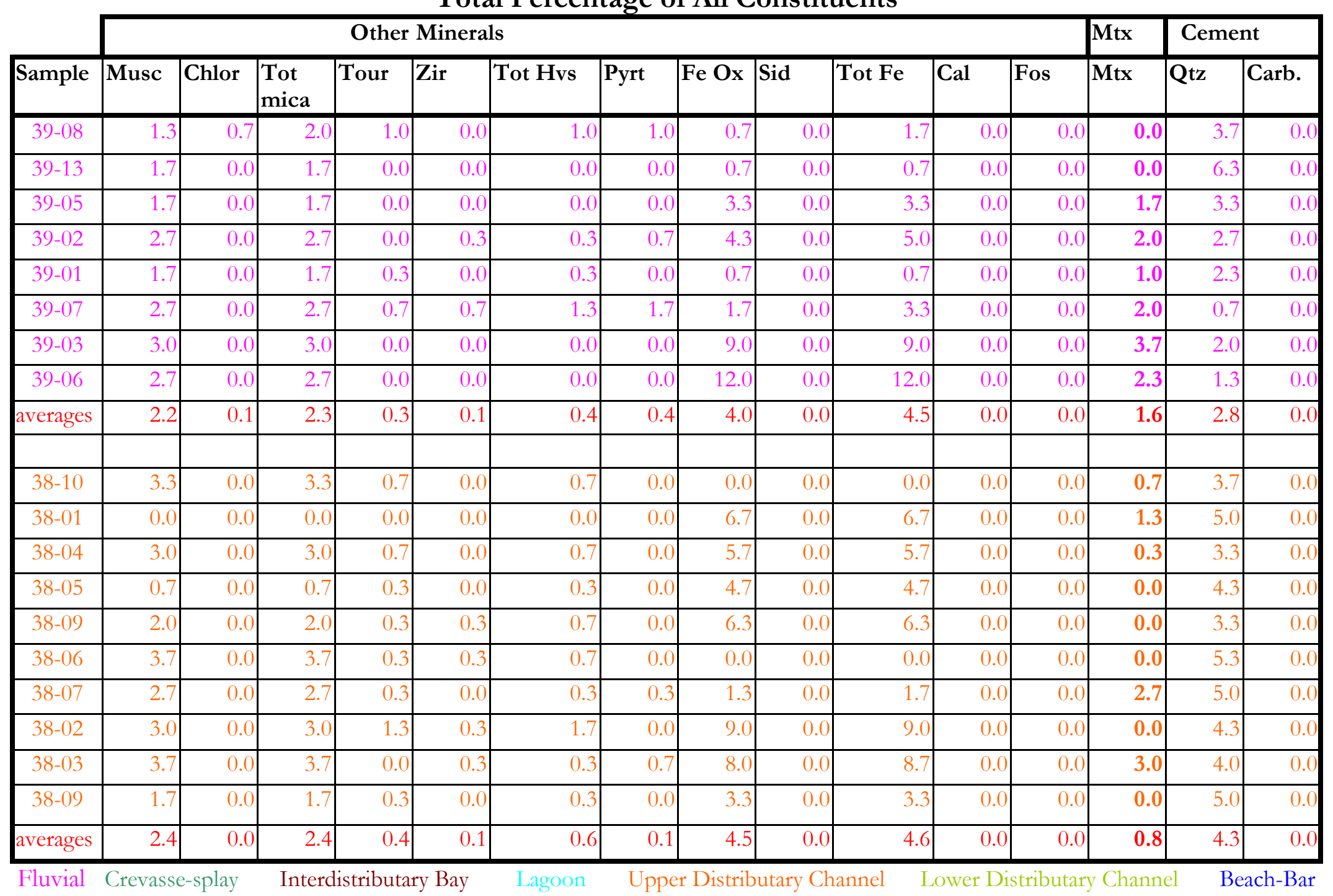


Total Percentage of All Constituents

\begin{tabular}{|c|c|c|c|c|c|c|c|c|c|c|c|c|c|}
\hline & \multicolumn{5}{|c|}{ Quartz } & \multicolumn{3}{|c|}{ Feldspar } & \multicolumn{5}{|c|}{ Rock Frags } \\
\hline Sample & Norm & Und & Poly & Cht & Total Q & Plag & K-spar & Total Feld & Sh & Phyl & Sch & Oth & Total Rx \\
\hline $34-01$ & 22.0 & 29.0 & 10.3 & 0.3 & 61.7 & 0.3 & 0.0 & 0.3 & 13.7 & 3.7 & 8.3 & 0.0 & 25.7 \\
\hline $32-05$ & 30.0 & 27.7 & 6.3 & 0.0 & 64.0 & 0.7 & 0.0 & 0.7 & 8.7 & 2.3 & 8.7 & 0.0 & 19.7 \\
\hline $32-02$ & 33.0 & 26.7 & 10.3 & 0.3 & $\begin{array}{l}70.3 \\
\end{array}$ & 0.3 & 0.0 & 0.3 & 7.3 & 3.3 & 6.7 & 0.0 & 17.3 \\
\hline $32-04$ & 30.0 & 22.3 & 3.7 & 0.0 & 56.0 & 0.3 & 0.0 & 0.3 & 13.3 & 3.0 & 6.3 & 0.0 & 22.7 \\
\hline averages & 28.8 & 26.4 & 7.7 & 0.2 & 63.0 & 0.4 & 0.0 & 0.4 & 10.8 & 3.1 & 7.5 & 0.0 & 21.3 \\
\hline 29-01 & 15.3 & 26.0 & 5.0 & 0.7 & 47.0 & 0.0 & 0.0 & 0.0 & 15.0 & 1.0 & 3.0 & 0.0 & 19.0 \\
\hline $31-04$ & 19.0 & 24.3 & 0.0 & 0.0 & 43.3 & 0.0 & 0.0 & 0.0 & 4.0 & 0.0 & 0.7 & 0.0 & 4.7 \\
\hline $31-05$ & 34.0 & 27.7 & 2.7 & 0.0 & $\begin{array}{ll}64.3 \\
\end{array}$ & 0.0 & 0.0 & 0.0 & 7.3 & 1.0 & 3.0 & 0.0 & 11.3 \\
\hline averages & 22.8 & 26.0 & 2.6 & 0.2 & 51.6 & 0.0 & 0.0 & 0.0 & 8.8 & 0.7 & 2.2 & 0.0 & 11.7 \\
\hline $27-02$ & 33.7 & 36.3 & 8.3 & 0.7 & \begin{tabular}{|l|}
79.0 \\
\end{tabular} & 0.0 & 0.0 & 0.0 & 2.7 & 0.7 & 8.0 & 0.0 & 11.3 \\
\hline $27-01$ & 34.3 & 29.0 & 8.3 & 0.0 & 71.7 & 0.0 & 0.0 & 0.0 & 2.0 & 1.0 & 8.0 & 0.0 & 11.0 \\
\hline $26-12$ & 37.3 & 32.7 & 8.3 & 1.0 & \begin{tabular}{|l|}
79.3 \\
\end{tabular} & 0.0 & 0.0 & 0.0 & 5.7 & 0.3 & 2.3 & 0.0 & 8.3 \\
\hline $26-01$ & 35.0 & 27.7 & 7.7 & 0.7 & 71.0 & 0.0 & 0.0 & 0.0 & 11.3 & 2.7 & 4.0 & 0.0 & 18.0 \\
\hline $26-02$ & 33.3 & 28.3 & 8.3 & 0.3 & 70.3 & 0.0 & 0.3 & 0.3 & 12.0 & 0.3 & 2.0 & 0.0 & 14.3 \\
\hline $26-05$ & 36.3 & 23.7 & 9.3 & 0.7 & 70.0 & 0.0 & 0.0 & 0.0 & 8.3 & 0.7 & 6.3 & 0.0 & 15.3 \\
\hline $26-07$ & 33.3 & 25.7 & 11.7 & 1.3 & 72.0 & 0.0 & 0.0 & 0.0 & 7.3 & 1.0 & 7.3 & 0.0 & 15.7 \\
\hline 26-09 & 38.7 & 21.0 & 13.0 & 0.3 & 73.0 & 0.0 & 0.0 & 0.0 & 12.7 & 0.3 & 4.3 & 0.0 & 17.3 \\
\hline $25-02$ & 31.0 & 23.0 & 3.7 & 0.0 & \begin{tabular}{|l|}
57.7 \\
\end{tabular} & 0.0 & 0.0 & 0.0 & 8.7 & 1.3 & 2.0 & 0.0 & 12.0 \\
\hline $25-06$ & 44.3 & 39.7 & 8.7 & 0.7 & $\begin{array}{l}3.3 \\
\end{array}$ & 0.0 & 0.0 & 0.0 & 0.3 & 0.0 & 1.0 & 0.0 & 1.3 \\
\hline $24-01$ & 10.3 & 19.3 & 14.3 & 0.0 & 44.0 & 0.0 & 0.0 & 0.0 & 1.3 & 0.0 & 0.0 & 15.3 & 16.7 \\
\hline $24-02$ & 9.0 & 12.7 & 10.7 & 0.7 & \begin{tabular}{|l|}
33.0 \\
\end{tabular} & 0.0 & 0.0 & 0.0 & 0.0 & 0.0 & 0.0 & 11.0 & 11.0 \\
\hline $26-02$ & 25.0 & 31.0 & 0.3 & 0.0 & \begin{tabular}{|l|}
56.3 \\
\end{tabular} & 0.0 & 0.0 & 0.0 & 4.0 & 0.0 & 0.0 & 0.0 & 4.0 \\
\hline averages & 30.9 & 26.9 & 8.7 & 0.5 & 67.0 & 0.0 & 0.0 & 0.0 & 5.9 & 0.6 & 3.5 & 2.0 & 12.0 \\
\hline
\end{tabular}


Total Percentage for All Constituents

\begin{tabular}{|c|c|c|c|c|c|c|c|c|c|c|c|c|c|c|c|}
\hline & & & & Other & Minera & & & & & & & & Mtx & Cemer & \\
\hline Sample & Musc & Chlor & $\begin{array}{l}\text { Tot } \\
\text { mica }\end{array}$ & Tour & Zir & Tot Hvs & Pyrt & $\mathrm{Fe} O \mathrm{x}$ & Sid & Tot Fe & Cal & Fos & Mtx & Qtz & Carb. \\
\hline 34-01 & 1.0 & 0.7 & 1.7 & 0.7 & 0.0 & 0.7 & 0.0 & 1.3 & 0.0 & 1.3 & 0.0 & 0.0 & 8.3 & 0.3 & 0.0 \\
\hline $32-05$ & 1.7 & 1.3 & 3.0 & 0.7 & 0.7 & 1.3 & 0.7 & 1.0 & 1.3 & 3.0 & 0.0 & 0.0 & 7.0 & 1.3 & 0.0 \\
\hline $32-02$ & 2.3 & 2.0 & 4.3 & 0.3 & 0.0 & 0.3 & 0.3 & 0.3 & 0.0 & 0.7 & 0.0 & 0.0 & 4.7 & 2.0 & 0.0 \\
\hline $32-04$ & 3.3 & 1.7 & 5.0 & 0.3 & 0.0 & 0.3 & 0.0 & 8.0 & 0.0 & 8.0 & 0.0 & 0.0 & 6.7 & 1.0 & 0.0 \\
\hline averages & 2.1 & 1.4 & 3.5 & 0.5 & 0.2 & 0.7 & 0.3 & 2.7 & 0.3 & 3.3 & 0.0 & 0.0 & 6.7 & 1.2 & 0.0 \\
\hline $29-01$ & 0.7 & 1.7 & 2.3 & 0.0 & 0.0 & 0.0 & 1.7 & 3.3 & 0.0 & 5.0 & 0.0 & 0.0 & 26.7 & 0.0 & $\overline{0.0}$ \\
\hline $31-04$ & 9.3 & 4.0 & 13.3 & 0.0 & 0.0 & 0.0 & 5.3 & 2.7 & 0.0 & 8.0 & 0.0 & 0.0 & 30.7 & 0.0 & 0.0 \\
\hline $31-05$ & 1.7 & 1.3 & 3.0 & 0.3 & 2.0 & 2.3 & 2.7 & 2.0 & 0.0 & 4.7 & 0.0 & 0.0 & 13.3 & 1.0 & $\overline{0.0}$ \\
\hline averages & 3.9 & 2.3 & 6.2 & 0.1 & 0.7 & 0.8 & 3.2 & 2.7 & 0.0 & 5.9 & 0.0 & 0.0 & 23.6 & 0.3 & 0.0 \\
\hline $27-02$ & 0.0 & 0.0 & 0.0 & 0.0 & 0.0 & 0.0 & 0.3 & 0.3 & 1.7 & 2.3 & 0.0 & 0.0 & 3.3 & 4.0 & 0.0 \\
\hline $27-01$ & 0.0 & 7.7 & 7.7 & 0.0 & 0.0 & $\overline{0.0}$ & 0.0 & 3.7 & 0.0 & 3.7 & 0.0 & 0.0 & 2.7 & 3.3 & 0.0 \\
\hline $26-12$ & 0.0 & 0.3 & 0.3 & 0.0 & 0.0 & 0.0 & 0.7 & 0.7 & 3.0 & 4.3 & 0.0 & 0.0 & 5.0 & 2.7 & 0.0 \\
\hline $26-01$ & 1.3 & 1.0 & 2.3 & 0.0 & 0.0 & $\overline{0.0}$ & 0.3 & 0.0 & 1.3 & 1.7 & 0.0 & 0.0 & 5.3 & 1.7 & 0.0 \\
\hline $26-02$ & 2.0 & 1.3 & 3.3 & 0.0 & 0.0 & 0.0 & 0.3 & 1.0 & 0.0 & 1.3 & 0.0 & 0.0 & 7.7 & 2.7 & 0.0 \\
\hline $26-05$ & 1.7 & 0.3 & 2.0 & 0.0 & 0.0 & 0.0 & 4.0 & 0.3 & 0.0 & 4.3 & 0.0 & 0.0 & 6.3 & 2.0 & 0.0 \\
\hline 26-07 & 1.3 & 1.0 & 2.3 & 0.0 & 0.0 & 0.0 & 0.0 & 1.0 & 0.0 & 1.0 & 0.0 & 0.0 & 8.3 & 0.7 & 0.0 \\
\hline $26-09$ & 0.3 & 0.0 & 0.3 & 0.0 & 0.3 & 0.3 & 0.0 & 2.3 & 0.0 & 2.3 & 0.0 & 0.0 & 6.0 & 0.7 & 0.0 \\
\hline $25-02$ & 2.7 & 1.3 & 4.0 & 0.0 & 0.3 & 0.3 & 3.0 & 0.0 & 0.0 & 3.0 & 0.0 & 0.0 & 23.0 & 0.0 & 0.0 \\
\hline $25-06$ & 0.3 & 0.0 & 0.3 & 0.0 & 0.0 & 0.0 & 0.0 & 0.0 & 0.0 & 0.0 & 0.0 & 0.0 & 1.0 & 4.0 & 0.0 \\
\hline 24-01 & 0.0 & 0.0 & 0.0 & 0.0 & 1.3 & 1.3 & 0.3 & 0.3 & 0.0 & 0.7 & 17.7 & 1.7 & 11.3 & 0.0 & 6.7 \\
\hline 24-02 & 0.0 & 0.0 & 0.0 & 0.0 & 0.0 & 0.0 & 0.0 & 0.0 & 0.0 & 0.0 & 6.3 & 13.3 & 36.3 & 0.0 & 0.0 \\
\hline $26-02$ & 1.0 & 1.0 & 2.0 & 0.0 & 0.0 & 0.0 & 1.3 & 2.0 & 0.0 & 3.3 & 0.0 & 0.0 & 34.3 & 0.0 & 0.0 \\
\hline averages & 0.8 & 1.1 & 1.9 & 0.0 & 0.2 & 0.2 & 0.8 & 0.9 & 0.5 & 2.2 & 1.8 & 1.2 & 11.6 & 1.7 & 0.5 \\
\hline
\end{tabular}

Fluvial Crevasse-splay Interdistributary Bay Lagoon Upper Distributary Channel Lower Distributary Channel Beach-Bar 
Total Percentage for All Constituents

\begin{tabular}{|c|c|c|c|c|c|c|c|c|c|c|c|c|c|}
\hline & \multicolumn{5}{|c|}{$\overline{\text { Quartz }}$} & \multicolumn{3}{|c|}{ Feldspar } & \multicolumn{5}{|c|}{ Rock Frags } \\
\hline Sample & Norm & Und & Poly & Cht & Total Q & Plag & K-spar & Total Feld & Sh & Phyl & Sch & Oth & Total Rx \\
\hline $36-03$ & 33.7 & 39.7 & 12.7 & 0.7 & 86.7 & 0.0 & 0.0 & 0.0 & 0.7 & 1.0 & 5.3 & 0.0 & 7.0 \\
\hline $36-02$ & 41.0 & 35.0 & 9.0 & 0.0 & 85.0 & 0.0 & 0.0 & 0.0 & 0.3 & 1.7 & 8.0 & 0.0 & 10.0 \\
\hline $36-01$ & 42.7 & 32.0 & 8.7 & 0.3 & 83.7 & 0.3 & 0.0 & 0.3 & 1.0 & 1.3 & 4.7 & $\overline{0.0}$ & 7.0 \\
\hline averages & 39.1 & 35.6 & 10.1 & 0.3 & 85.1 & 0.1 & 0.0 & 0.1 & 0.7 & 1.3 & 6.0 & $\overline{0.0}$ & 8.0 \\
\hline $18-01$ & 13.0 & 25.0 & 34.3 & 1.7 & 74.0 & 0.0 & 0.0 & 0.0 & 0.3 & 0.0 & 0.0 & 0.0 & 0.3 \\
\hline $07-03$ & 23.0 & 36.7 & 14.3 & 0.0 & 74.0 & 0.0 & 0.0 & 0.0 & 2.7 & 0.0 & 0.0 & 0.0 & 2.7 \\
\hline $07-04$ & 26.3 & 30.3 & 4.7 & 0.0 & 61.3 & 0.3 & 0.0 & 0.3 & 1.7 & 0.0 & 4.3 & 0.0 & 6.0 \\
\hline 07-02 & 33.3 & 31.0 & 9.0 & 0.3 & 73.7 & 0.0 & 0.0 & 0.0 & 2.7 & 0.0 & 2.3 & 0.0 & 5.0 \\
\hline 07-01 & 10.3 & 21.7 & 17.3 & 0.3 & 49.7 & 0.0 & 0.0 & 0.0 & 0.0 & 0.0 & 2.0 & 4.0 & 6.0 \\
\hline 06-01 & 32.7 & 23.7 & 1.7 & 0.0 & 58.0 & 0.0 & 0.0 & 0.0 & 18.0 & 0.0 & 0.3 & 0.0 & 18.3 \\
\hline $\begin{array}{l}08-01 \\
\end{array}$ & 31.0 & 36.3 & 2.0 & 0.0 & 69.3 & 0.0 & 0.0 & 0.0 & 6.0 & 0.0 & 1.3 & 0.0 & 7.3 \\
\hline $22-01$ & 27.0 & 26.0 & 1.0 & 0.0 & 0.0 & 0.0 & 0.3 & 1.3 & 0.3 & 0.0 & 3.7 & 0.7 & 0.0 \\
\hline $20-01$ & 35.7 & 43.3 & 1.7 & 0.0 & 80.7 & 0.0 & 0.0 & 0.0 & 0.0 & 0.7 & 2.7 & 0.0 & 3.3 \\
\hline 14-01 & 30.0 & 30.7 & 4.0 & 0.3 & 65.0 & 0.3 & 0.0 & 0.3 & 1.7 & 2.3 & 3.7 & $\overline{0.0}$ & 7.7 \\
\hline $12-01$ & 27.7 & 18.7 & 0.0 & 0.0 & 46.3 & 0.0 & 0.0 & 0.0 & 0.0 & 0.3 & 0.3 & 0.0 & 0.7 \\
\hline $12-02$ & 31.0 & 31.3 & 1.7 & 0.0 & 64.0 & 0.0 & 0.0 & 0.0 & 3.0 & 0.0 & 4.0 & 0.0 & 7.0 \\
\hline $12-03$ & 28.0 & 27.3 & 0.3 & 0.0 & 55.7 & 0.0 & 0.0 & 0.0 & 2.3 & 0.7 & 0.3 & 0.0 & 3.3 \\
\hline $12-04$ & 35.0 & 30.3 & 2.3 & 0.3 & 68.0 & 0.0 & 2.3 & 2.3 & 5.0 & 0.0 & 0.7 & 0.0 & 5.7 \\
\hline $10-02$ & 21.3 & 16.7 & 0.0 & 0.0 & 38.0 & 0.0 & 0.0 & 0.0 & 4.3 & 0.0 & 0.0 & $\overline{0.0}$ & 4.3 \\
\hline 10-01 & 26.7 & 21.3 & 1.0 & 0.0 & \begin{tabular}{|l|}
49.0 \\
\end{tabular} & 0.0 & 0.0 & 0.0 & 3.7 & 0.0 & 0.0 & 0.0 & 3.7 \\
\hline 01-02 & 30.7 & 30.3 & 1.0 & 0.3 & $\begin{array}{l}62.3 \\
\end{array}$ & 0.0 & 0.0 & 0.0 & 4.0 & 0.0 & 0.7 & 0.0 & 4.7 \\
\hline averages & 27.2 & 28.3 & 5.7 & 0.2 & 58.2 & 0.0 & 0.2 & 0.3 & 3.3 & 0.2 & 1.5 & 0.3 & 5.1 \\
\hline
\end{tabular}

Fluvial Crevasse-splay $\quad$ Interdistributary Bay Lagoon $\quad$ Upper Distributary Channel $\quad$ Lower Distributary Channel Beach-Bar 
Total Percentages of All Constituents

\begin{tabular}{|c|c|c|c|c|c|c|c|c|c|c|c|c|c|c|c|}
\hline & & & & Other & Minera & & & & & & & & Mtx & Ceme & \\
\hline Sample & Musc & Chlor & Tot mica & Tour & Zir & Tot Hvs & Pyrt & Fe Ox & Sid & Tot Fe & Cal & Fos & Mtx & Qtz & Carb. \\
\hline $36-03$ & 0.0 & 0.0 & 0.0 & 0.0 & 0.0 & 0.0 & 0.0 & 1.7 & 0.0 & 1.7 & 0.0 & 0.0 & 2.0 & 2.7 & 0.0 \\
\hline $36-02$ & 0.7 & 0.0 & 0.7 & 0.0 & 0.0 & 0.0 & 0.0 & 0.3 & 0.0 & 0.3 & 0.0 & 0.0 & 2.0 & 2.0 & 0.0 \\
\hline $36-01$ & 0.3 & 0.0 & 0.3 & 0.0 & 0.0 & 0.0 & 0.0 & 4.0 & 0.0 & 4.0 & 0.0 & 0.0 & 3.3 & 1.3 & 0.0 \\
\hline averages & 0.3 & 0.0 & 0.3 & 0.0 & 0.0 & 0.0 & 0.0 & 2.0 & 0.0 & 2.0 & 0.0 & 0.0 & 2.4 & 2.0 & 0.0 \\
\hline $18-01$ & 0.0 & 0.0 & 0.0 & 0.0 & 0.0 & 0.0 & 1.0 & 0.0 & 0.0 & 1.0 & 0.0 & 0.0 & 24.7 & 0.0 & 0.0 \\
\hline $07-03$ & 1.3 & 1.0 & 2.3 & 0.0 & 0.0 & 0.0 & 0.3 & 5.0 & 0.0 & 5.3 & 0.0 & 0.0 & 15.7 & 0.0 & 0.0 \\
\hline $07-04$ & 2.0 & 3.0 & 5.0 & 0.0 & 0.3 & 0.3 & 1.0 & 1.7 & 3.7 & 6.3 & 0.0 & 0.0 & 20.7 & 0.0 & 0.0 \\
\hline $07-02$ & 0.7 & 1.7 & 2.3 & 0.0 & 0.7 & 0.7 & 0.7 & 0.0 & 6.7 & 7.3 & 0.0 & 0.0 & 11.0 & 0.0 & 0.0 \\
\hline 07-01 & 0.0 & 0.7 & 0.7 & 0.0 & 0.0 & 0.0 & 0.3 & 0.0 & 40.7 & 41.0 & 0.0 & 0.0 & 2.7 & 0.0 & 0.0 \\
\hline 06-01 & 1.3 & 1.7 & 3.0 & 0.3 & 0.0 & 0.3 & 1.3 & 0.0 & 1.7 & 3.0 & 0.0 & 0.0 & 17.3 & 0.0 & 0.0 \\
\hline 08-01 & 1.3 & 1.3 & 2.7 & 0.0 & 0.0 & 0.0 & 1.0 & 1.0 & 0.0 & 2.0 & 0.0 & 0.0 & 18.7 & 0.0 & 0.0 \\
\hline $22-01$ & 0.0 & 36.7 & 3.0 & 0.0 & 0.0 & 0.0 & 0.0 & 0.0 & 0.0 & 0.0 & 0.0 & 0.0 & 36.7 & 0.0 & 0.0 \\
\hline $20-01$ & 1.0 & 0.0 & 1.0 & 0.7 & 0.0 & 0.7 & 1.7 & 2.0 & 0.0 & 3.7 & 0.0 & 0.0 & 10.0 & 0.7 & 0.0 \\
\hline 14-01 & 0.3 & 1.0 & 1.3 & 0.0 & 0.3 & 0.3 & 6.7 & 0.7 & 1.0 & 8.3 & 0.0 & 0.0 & 17.0 & 0.0 & 0.0 \\
\hline $12-01$ & 3.3 & 4.0 & 7.3 & 0.0 & 0.3 & 0.3 & 3.3 & 0.0 & 0.0 & 3.3 & 0.0 & 0.0 & 42.0 & 0.0 & 0.0 \\
\hline $12-02$ & 2.3 & 2.7 & 5.0 & 0.0 & 0.0 & 0.0 & 1.0 & 5.0 & 0.0 & 6.0 & 0.0 & 0.0 & 16.3 & 1.7 & 0.0 \\
\hline $12-03$ & 3.3 & 2.7 & 6.0 & 0.0 & 0.0 & 0.0 & 5.7 & 0.0 & 0.0 & 5.7 & 0.0 & 0.0 & 29.3 & 0.0 & 0.0 \\
\hline $12-04$ & 2.0 & 0.0 & 2.0 & 0.0 & 0.0 & 0.0 & 1.3 & 0.0 & 0.0 & 1.3 & 0.0 & 0.0 & 20.7 & 0.0 & 0.0 \\
\hline $10-02$ & 2.7 & 1.3 & 4.0 & 0.0 & 0.0 & 0.0 & 3.7 & 0.0 & 0.0 & 3.7 & 0.0 & 0.0 & 50.0 & 0.0 & 0.0 \\
\hline $10-01$ & 0.7 & 2.0 & 2.7 & 0.0 & 0.0 & 0.0 & 4.3 & 0.0 & 0.0 & 4.3 & 0.0 & 0.0 & 40.3 & 0.0 & 0.0 \\
\hline $01-02$ & 4.0 & 2.0 & 6.0 & 0.0 & 0.0 & 0.0 & 4.0 & 0.0 & 4.3 & 8.3 & 0.0 & 0.0 & 18.7 & 0.0 & 0.0 \\
\hline averages & 1.5 & 3.6 & 3.2 & 0.1 & 0.1 & 0.2 & 2.2 & 0.9 & 3.4 & 6.5 & 0.0 & 0.0 & 23.0 & 0.1 & 0.0 \\
\hline
\end{tabular}

Fluvial Crevasse-splay Interdistributary Bay 
Percentages of Ouartz, Feldspar, and Lithic Fragments

\begin{tabular}{|c|c|c|c|c|c|c|c|c|c|c|c|c|c|}
\hline Sample & Norm & Und & Poly & Cht & $\%$ Quartz & Plag & K-spar & $\%$ Feldspar & Sh & Phyl & Sch & Oth & $\%$ Lithics \\
\hline 39-08 & 40.4 & 33.8 & 12.4 & 0.7 & 87.3 & 1.1 & 0.0 & 1.1 & 0.4 & 4.7 & 6.5 & 0.0 & 11.6 \\
\hline $39-13$ & 32.5 & 38.7 & 13.5 & 0.4 & 85.0 & 1.1 & 1.1 & 2.2 & 1.5 & 3.6 & 7.7 & 0.0 & 12.8 \\
\hline 39-05 & 31.9 & 28.5 & 18.1 & 2.2 & 80.7 & 0.7 & 0.7 & 1.5 & 1.5 & 4.8 & 11.5 & 0.0 & 17.8 \\
\hline 39-02 & 31.3 & 26.3 & 15.6 & 1.1 & 74.4 & 1.9 & 0.8 & 2.7 & 1.9 & 3.8 & 17.2 & 0.0 & 22.9 \\
\hline 39-01 & 38.3 & 33.3 & 13.5 & 1.1 & 86.2 & 0.0 & 0.4 & 0.4 & 0.4 & 2.5 & 10.6 & 0.0 & 13.5 \\
\hline 39-07 & 36.3 & 34.4 & 13.0 & 0.7 & 84.4 & 0.7 & 1.1 & 1.9 & 1.5 & 3.3 & 8.9 & 0.0 & 13.7 \\
\hline 39-03 & 41.7 & 35.6 & 9.7 & 0.8 & 87.9 & 0.4 & 0.4 & 0.8 & 1.2 & 3.6 & 6.5 & 0.0 & 11.3 \\
\hline $39-06$ & 49.4 & 32.7 & 9.4 & 0.4 & 91.8 & 0.4 & 0.0 & 0.4 & 0.4 & 3.7 & 3.7 & 0.0 & 7.8 \\
\hline $38-10$ & 48.7 & 19.6 & 13.1 & 1.8 & 83.3 & 2.5 & 1.5 & 4.0 & 1.1 & 8.0 & 3.6 & 0.0 & 12.7 \\
\hline 38-01 & 42.9 & 19.9 & 13.0 & 1.1 & 77.0 & 0.4 & 0.8 & 1.1 & 11.5 & 6.5 & 3.8 & 0.0 & 21.8 \\
\hline $38-04$ & 41.8 & 31.0 & 11.5 & 1.1 & 85.4 & 0.0 & 0.0 & 0.0 & 1.1 & 8.4 & 5.0 & 0.0 & 14.6 \\
\hline $38-05$ & 50.7 & 25.2 & 11.5 & 1.1 & 88.5 & 0.4 & 0.0 & 0.4 & 1.1 & 6.3 & 3.7 & 0.0 & 11.1 \\
\hline 38-08 & 39.2 & 33.1 & 11.4 & 0.8 & 84.4 & 0.4 & 0.0 & 0.4 & 1.9 & 9.1 & 4.2 & 0.0 & 15.2 \\
\hline $38-06$ & 41.7 & 29.9 & 10.0 & 0.7 & 82.3 & 1.8 & 0.4 & 2.2 & 1.8 & 8.9 & 4.8 & 0.0 & 15.5 \\
\hline 38-07 & 37.6 & 33.1 & 16.7 & 0.4 & 87.8 & 0.8 & 0.4 & 1.1 & 1.9 & 4.2 & 4.9 & 0.0 & 11.0 \\
\hline 38-02 & 47.6 & 26.0 & 15.0 & 0.4 & 89.0 & 0.0 & 0.4 & 0.4 & 0.8 & 5.3 & 4.5 & 0.0 & 10.6 \\
\hline $38-03$ & 42.7 & 27.4 & 10.0 & 0.4 & 80.5 & 0.4 & 0.4 & 0.8 & 6.2 & 7.5 & 5.0 & 0.0 & 18.7 \\
\hline 38-09 & 40.9 & 28.3 & 14.5 & 1.5 & 85.1 & 0.4 & 0.0 & 0.4 & 0.4 & 5.9 & 8.2 & 0.0 & 14.5 \\
\hline 34-01 & 25.1 & 33.1 & 11.8 & 0.4 & 70.3 & 0.4 & 0.0 & 0.4 & 15.6 & 4.2 & 9.5 & 0.0 & 29.3 \\
\hline $32-05$ & 35.6 & 32.8 & 7.5 & 0.0 & 75.9 & 0.8 & 0.0 & 0.8 & 10.3 & 2.8 & 10.3 & 0.0 & 23.3 \\
\hline $32-02$ & 37.5 & 30.3 & 11.7 & 0.4 & 79.9 & 0.4 & 0.0 & 0.4 & 8.3 & 3.8 & 7.6 & 0.0 & 19.7 \\
\hline $32-04$ & 38.0 & 28.3 & 4.6 & 0.0 & 70.9 & 0.4 & 0.0 & 0.4 & 16.9 & 3.8 & 8.0 & 0.0 & 28.7 \\
\hline
\end{tabular}

Fluvial Crevasse-splay Interdistributary Bay 
Percentages of Quartz, Feldspar, and Lithic Fragments

\begin{tabular}{|c|c|c|c|c|c|c|c|c|c|c|c|c|c|}
\hline Sample & Norm & Und & Poly & Cht & $\%$ Quartz & Plag & K-spar & $\%$ Feldspar & Sh & Phyl & Sch & Oth & \% Lithics \\
\hline $36-03$ & 35.9 & 42.3 & 13.5 & 0.7 & 92.5 & 0.0 & 0.0 & 0.0 & 0.7 & 1.1 & 5.7 & 0.0 & 7.5 \\
\hline $36-02$ & 43.2 & 36.8 & 9.5 & 0.0 & 89.5 & 0.0 & 0.0 & 0.0 & 0.4 & 1.8 & 8.4 & 0.0 & 10.5 \\
\hline $36-01$ & 46.9 & 35.2 & 9.5 & 0.4 & 91.9 & 0.4 & 0.0 & 0.4 & 1.1 & 1.5 & 5.1 & 0.0 & 7.7 \\
\hline 29-01 & 23.2 & 39.4 & 7.6 & 1.0 & 71.2 & 0.0 & 0.0 & 0.0 & 22.7 & 1.5 & 4.5 & 0.0 & 28.8 \\
\hline 31-04 & 39.6 & 50.7 & 0.0 & 0.0 & 90.3 & 0.0 & 0.0 & 0.0 & 8.3 & 0.0 & 1.4 & 0.0 & 9.7 \\
\hline 31-05 & 44.9 & 36.6 & 3.5 & 0.0 & 85.0 & 0.0 & 0.0 & 0.0 & 9.7 & 1.3 & 4.0 & 0.0 & 15.0 \\
\hline $27-02$ & 37.3 & 40.2 & 9.2 & 0.7 & 87.5 & 0.0 & 0.0 & 0.0 & 3.0 & 0.7 & 8.9 & 0.0 & 12.5 \\
\hline 27-01 & 41.5 & 35.1 & 10.1 & 0.0 & 86.7 & 0.0 & 0.0 & 0.0 & 2.4 & 1.2 & 9.7 & 0.0 & 13.3 \\
\hline 26-12 & 42.6 & 37.3 & 9.5 & 1.1 & 90.5 & 0.0 & 0.0 & 0.0 & 6.5 & 0.4 & 2.7 & 0.0 & 9.5 \\
\hline 26-01 & 39.3 & 31.1 & 8.6 & 0.7 & 79.8 & 0.0 & 0.0 & 0.0 & 12.7 & 3.0 & 4.5 & 0.0 & 20.2 \\
\hline 26-02 & 39.2 & 33.3 & 9.8 & 0.4 & 82.7 & 0.0 & 0.4 & 0.4 & 14.1 & 0.4 & 2.4 & 0.0 & 16.9 \\
\hline 26-05 & 42.6 & 27.7 & 10.9 & 0.8 & 82.0 & 0.0 & 0.0 & 0.0 & 9.8 & 0.8 & 7.4 & 0.0 & 18.0 \\
\hline 26-07 & 38.0 & 29.3 & 13.3 & 1.5 & 82.1 & 0.0 & 0.0 & 0.0 & 8.4 & 1.1 & 8.4 & 0.0 & 17.9 \\
\hline 26-09 & 42.8 & 23.2 & 14.4 & 0.4 & 80.8 & 0.0 & 0.0 & 0.0 & 14.0 & 0.4 & 4.8 & 0.0 & 19.2 \\
\hline $25-02$ & 44.5 & 33.0 & 5.3 & 0.0 & 82.8 & 0.0 & 0.0 & 0.0 & 12.4 & 1.9 & 2.9 & 0.0 & 17.2 \\
\hline $25-06$ & 46.8 & 41.9 & 9.2 & 0.7 & 98.6 & 0.0 & 0.0 & 0.0 & 0.4 & 0.0 & 1.1 & 0.0 & 1.4 \\
\hline 24-01 & 17.0 & 31.9 & 23.6 & 0.0 & 72.5 & 0.0 & 0.0 & 0.0 & 2.2 & 0.0 & 0.0 & 25.3 & 27.5 \\
\hline 24-02 & 20.5 & 28.8 & 24.2 & 1.5 & 75.0 & 0.0 & 0.0 & 0.0 & 0.0 & 0.0 & 0.0 & 25.0 & 25.0 \\
\hline 26-02 & 41.4 & 51.4 & 0.6 & 0.0 & 93.4 & 0.0 & 0.0 & 0.0 & 6.6 & 0.0 & 0.0 & 0.0 & 6.6 \\
\hline
\end{tabular}


Percentages of Quartz, Feldspar, and Lithic Fragments

\begin{tabular}{|c|c|c|c|c|c|c|c|c|c|c|c|c|c|}
\hline Sample & Norm & Und & Poly & Cht & \% Quartz & Plag & K-spar & $\%$ Feldspar & $\mathrm{Sh}$ & Phyl & Sch & Oth & $\%$ Lithics \\
\hline 18-01 & 17.5 & 33.6 & 46.2 & 2.2 & 99.6 & 0.0 & 0.0 & 0.0 & 0.4 & 0.0 & 0.0 & 0.0 & 0.4 \\
\hline 07-03 & 30.0 & 47.8 & 18.7 & 0.0 & 96.5 & 0.0 & 0.0 & 0.0 & 3.5 & 0.0 & 0.0 & 0.0 & 3.5 \\
\hline $07-04$ & 38.9 & 44.8 & 6.9 & 0.0 & 90.6 & 0.5 & 0.0 & 0.5 & 2.5 & 0.0 & 6.4 & 0.0 & 8.9 \\
\hline 07-02 & 42.4 & 39.4 & 11.4 & 0.4 & 93.6 & 0.0 & 0.0 & 0.0 & 3.4 & 0.0 & 3.0 & 0.0 & 6.4 \\
\hline 07-01 & 18.6 & 38.9 & 31.1 & 0.6 & 89.2 & 0.0 & 0.0 & 0.0 & 0.0 & 0.0 & 3.6 & 7.2 & 10.8 \\
\hline 06-01 & 42.8 & 31.0 & 2.2 & 0.0 & 76.0 & 0.0 & 0.0 & 0.0 & 23.6 & 0.0 & 0.4 & 0.0 & 24.0 \\
\hline 08-01 & 40.4 & 47.4 & 2.6 & 0.0 & 90.4 & 0.0 & 0.0 & 0.0 & 7.8 & 0.0 & 1.7 & 0.0 & 9.6 \\
\hline $22-01$ & 48.2 & 46.4 & 1.8 & 0.0 & 96.4 & 0.0 & 0.0 & 0.0 & 0.6 & 2.4 & 0.6 & 0.0 & 3.6 \\
\hline $20-01$ & 42.5 & 51.6 & 2.0 & 0.0 & 96.0 & 0.0 & 0.0 & 0.0 & 0.0 & 0.8 & 3.2 & 0.0 & 4.0 \\
\hline 14-01 & 41.1 & 42.0 & 5.5 & 0.5 & 89.0 & 0.5 & 0.0 & 0.5 & 2.3 & 3.2 & 5.0 & 0.0 & 10.5 \\
\hline 12-01 & 58.9 & 39.7 & 0.0 & 0.0 & 98.6 & 0.0 & 0.0 & 0.0 & 0.0 & 0.7 & 0.7 & 0.0 & 1.4 \\
\hline $12-02$ & 43.7 & 44.1 & 2.3 & 0.0 & 90.1 & 0.0 & 0.0 & 0.0 & 4.2 & 0.0 & 5.6 & 0.0 & 9.9 \\
\hline $12-03$ & 47.5 & 46.3 & 0.6 & 0.0 & 94.4 & 0.0 & 0.0 & 0.0 & 4.0 & 1.1 & 0.6 & 0.0 & 5.6 \\
\hline $12-04$ & 46.1 & 39.9 & 3.1 & 0.4 & 89.5 & 0.0 & 3.1 & 3.1 & 6.6 & 0.0 & 0.9 & 0.0 & 7.5 \\
\hline $10-02$ & 50.4 & 39.4 & 0.0 & 0.0 & 89.8 & 0.0 & 0.0 & 0.0 & 10.2 & 0.0 & 0.0 & 0.0 & 10.2 \\
\hline 10-01 & 50.6 & 40.5 & 1.9 & 0.0 & 93.0 & 0.0 & 0.0 & 0.0 & 7.0 & 0.0 & 0.0 & 0.0 & 7.0 \\
\hline 01-02 & 45.8 & 45.3 & 1.5 & 0.5 & 93.0 & 0.0 & 0.0 & 0.0 & 6.0 & 0.0 & 1.0 & 0.0 & 7.0 \\
\hline
\end{tabular}

Fluvial Crevasse-splay Interdistributary Bay Lagoon Upper Distributary Channel Lower Distributary Channel Beach-Bar 
Percentages of Shale, Phyllite, Schist and Other Rock Fragments

\begin{tabular}{|c|r|r|r|r|r|}
\hline Sample & \multicolumn{1}{l|}{ Shale } & \multicolumn{1}{l}{ Phyllite } & \multicolumn{1}{l}{ Schist } & Other Rx & \multicolumn{1}{l|}{ Total } \\
\hline 39-08 & 3.13 & 40.63 & 56.25 & 0.00 & 100.00 \\
\hline $39-13$ & 11.43 & 28.57 & 60.00 & 0.00 & 100.00 \\
\hline $39-05$ & 8.33 & 27.08 & 64.58 & 0.00 & 100.00 \\
\hline $39-02$ & 8.33 & 16.67 & 75.00 & 0.00 & 100.00 \\
\hline $39-01$ & 2.63 & 18.42 & 78.95 & 0.00 & 100.00 \\
\hline $39-07$ & 10.81 & 24.32 & 64.86 & 0.00 & 100.00 \\
\hline $39-03$ & 10.71 & 32.14 & 57.14 & 0.00 & 100.00 \\
\hline $39-06$ & 5.26 & 47.37 & 47.37 & 0.00 & 100.00 \\
\hline Mean & 7.58 & 29.40 & 63.02 & 0.00 & 100.00 \\
\hline & & & & & \\
\hline $38-10$ & 8.57 & 62.86 & 28.57 & 0.00 & 100.00 \\
\hline $38-01$ & 52.63 & 29.82 & 17.54 & 0.00 & 100.00 \\
\hline $38-04$ & 7.89 & 57.89 & 34.21 & 0.00 & 100.00 \\
\hline $38-05$ & 10.00 & 56.67 & 33.33 & 0.00 & 100.00 \\
\hline $38-08$ & 12.50 & 60.00 & 27.50 & 0.00 & 100.00 \\
\hline $38-06$ & 11.90 & 57.14 & 30.95 & 0.00 & 100.00 \\
\hline $38-07$ & 17.24 & 37.93 & 44.83 & 0.00 & 100.00 \\
\hline $38-02$ & 7.69 & 50.00 & 42.31 & 0.00 & 100.00 \\
\hline $38-03$ & 33.33 & 40.00 & 26.67 & 0.00 & 100.00 \\
\hline $38-09$ & 2.56 & 41.03 & 56.41 & 0.00 & 100.00 \\
\hline Mean & 16.43 & 49.33 & 34.23 & 0.00 & 100.00 \\
\hline & & & & & \\
\hline $34-01$ & 53.25 & 14.29 & 32.47 & 0.00 & 100.00 \\
\hline $32-05$ & 44.07 & 11.86 & 44.07 & 0.00 & 100.00 \\
\hline $32-02$ & 42.31 & 19.23 & 38.46 & 0.00 & 100.00 \\
\hline $32-04$ & 58.82 & 13.24 & 27.94 & 0.00 & 100.00 \\
\hline Mean & 49.61 & 14.65 & 35.73 & 0.00 & 100.00 \\
\hline & & & & & \\
\hline $36-03$ & 9.52 & 14.29 & 76.19 & 0.00 & 100.00 \\
\hline $36-02$ & 3.33 & 16.67 & 80.00 & 0.00 & 100.00 \\
\hline $36-01$ & 14.29 & 19.05 & 66.67 & 0.00 & 100.00 \\
\hline Mean & 9.05 & 16.67 & 74.29 & 0.00 & 100.00 \\
\hline
\end{tabular}

Fluvial Crevasse-splay Interdistributary Bay Lagoon Upper Distributary Channel Lower Distributary Channel

Beach-Bar 
Percentages of Shale, Phyllite, Schist and Other Rock Fragments

\begin{tabular}{|c|c|c|c|c|c|}
\hline Sample & Shale & Phyllite & Schist & Other Rx & Total \\
\hline 29-01 & 78.95 & 5.26 & 15.79 & 0.00 & 100.00 \\
\hline $31-04$ & 85.71 & 0.00 & 14.29 & 0.00 & 100.00 \\
\hline $31-05$ & 64.71 & 8.82 & 26.47 & 0.00 & 100.00 \\
\hline Mean & 76.46 & 4.70 & 18.85 & 0.00 & 100.00 \\
\hline $27-02$ & 23.53 & 5.88 & 70.59 & 0.00 & 100.00 \\
\hline $27-01$ & 18.18 & 9.09 & 72.73 & 0.00 & 100.00 \\
\hline $26-12$ & 68.00 & 4.00 & 28.00 & 0.00 & 100.00 \\
\hline 26-01 & 62.96 & 14.81 & 22.22 & 0.00 & 100.00 \\
\hline $26-02$ & 83.72 & 2.33 & 13.95 & 0.00 & 100.00 \\
\hline $26-05$ & 54.35 & 4.35 & 41.30 & 0.00 & 100.00 \\
\hline $26-07$ & 46.81 & 6.38 & 46.81 & 0.00 & 100.00 \\
\hline $26-09$ & 73.08 & 1.92 & 25.00 & 0.00 & 100.00 \\
\hline $25-02$ & 72.22 & 11.11 & 16.67 & 0.00 & 100.00 \\
\hline $25-06$ & 25.00 & 0.00 & 75.00 & 0.00 & 100.00 \\
\hline 24-01 & 8.00 & 0.00 & 0.00 & 92.00 & 100.00 \\
\hline 24-02 & 0.00 & 0.00 & 0.00 & 100.00 & 100.00 \\
\hline $26-02$ & 100.00 & 0.00 & 0.00 & 0.00 & 100.00 \\
\hline Mean & 48.91 & 4.61 & 31.71 & 14.77 & 100.00 \\
\hline $18-01$ & 100.00 & 0.00 & 0.00 & 0.00 & 100.00 \\
\hline $07-03$ & 100.00 & 0.00 & 0.00 & 0.00 & 100.00 \\
\hline 07-04 & 27.78 & 0.00 & 72.22 & 0.00 & 100.00 \\
\hline $07-02$ & 53.33 & 0.00 & 46.67 & 0.00 & 100.00 \\
\hline 07-01 & 0.00 & 0.00 & 33.33 & 66.67 & 100.00 \\
\hline 06-01 & 98.18 & 0.00 & 1.82 & 0.00 & 100.00 \\
\hline 08-01 & 81.82 & 0.00 & 18.18 & 0.00 & 100.00 \\
\hline $22-01$ & 16.67 & 66.67 & 16.67 & 0.00 & 100.00 \\
\hline 20-01 & 0.00 & 20.00 & 80.00 & 0.00 & 100.00 \\
\hline 14-01 & 21.74 & 30.43 & 47.83 & 0.00 & 100.00 \\
\hline $12-01$ & 0.00 & 50.00 & 50.00 & 0.00 & 100.00 \\
\hline $12-02$ & 42.86 & 0.00 & 57.14 & 0.00 & 100.00 \\
\hline $12-03$ & 70.00 & 20.00 & 10.00 & 0.00 & 100.00 \\
\hline $12-04$ & 88.24 & 0.00 & 11.76 & 0.00 & 100.00 \\
\hline $10-02$ & 100.00 & 0.00 & 0.00 & 0.00 & 100.00 \\
\hline $10-01$ & 100.00 & 0.00 & 0.00 & 0.00 & 100.00 \\
\hline 01-02 & 85.71 & 0.00 & 14.29 & 0.00 & 100.00 \\
\hline Mean & 58.02 & 11.01 & 27.05 & 3.92 & 100.00 \\
\hline
\end{tabular}

Fluvial Crevasse-splay Interdistributary Bay Lagoon Upper Distributary Channel Lower Distributary Channel

Beach-Bar 